\section{DISCLAIMER}

This report was prepared as an account of work sponsored by an agency of the United States Government. Neither the United States Government nor any agency thereof, nor any of their employees, makes any warranty, express or implied, or assumes any legal liability or responsibility for the accuracy, completeness, or usefulness of any information, apparatus, product, or process disclosed, or represents that its use would not infringe privately owned rights. Reference herein to any specific commercial product, process, or service by trade name, trademark, manufacturer, or otherwise does not necessarily constitute or imply its endorsement, recommendation, or favoring by the United States Government or any agency thereof. The views and opinions of authors expressed herein do not necessarily state or reflect those of the United States Government or any agency thereof.

\section{Receiven hy OSTI}

JUL 071987

$\mathrm{DOE} / \mathrm{ID} / 12524--\mathrm{T} 2$

ALASKA GEOTHERMAL BIBLIOGRAPHY

DE87 011630

\author{
S. A. Liss, 1 R. J. Motyka, ${ }^{2}$ and C. J. NYe ${ }^{3}$ \\ Alaska Division of \\ Geological and Geophysical Surveys
}

May $=07$

This work was performed under Grant DE-FG07-84ID12524 from the U. S. Department of Energy and funding from the state of Alaska, Department of Natural Resources.

IAlaska Division of Geologlcal \& Geophysical surveys, Fairbanks, Alaska

${ }^{2}$ Alaska Division of Geological \& Geophysical Surveys, Juneau, Alaska

3unfversity of Alaska, Geophysical Institute, Falrbanks, Alaska 


\section{DISCLAIMER}

This report was prepared as an account of work sponsored by an agency of the United States Government. Neither the United States Government nor any agency Thereof, nor any of their employees, makes any warranty, express or implied, or assumes any legal liability or responsibility for the accuracy, completeness, or usefulness of any information, apparatus, product, or process disclosed, or represents that its use would not infringe privately owned rights. Reference herein to any specific commercial product, process, or service by trade name, trademark, manufacturer, or otherwise does not necessarily constitute or imply its endorsement, recommendation, or favoring by the United States Government or any agency thereof. The views and opinions of authors expressed herein do not necessarily state or reflect those of the United States Government or any agency thereof. 


\section{DISCLAIMER}

Portions of this document may be illegible in electronic image products. Images are produced from the best available original document. 
This report is a preliminary publication of the Alaska Division of Geological and Geophyscal surveys. The authors are solely responsible for its content and will appreciate candid comments on the accuracy as well as suggestions for improvement. 
CONTENTS

PAGE

INTRODUCTION - ALASKA GEOTHERMAL BIBLIOGRAPHY

SECTION I - STANDARD BIBLIOGRAPHICAL LISTING 5

SECTION II - AUTHOR IISTING $\quad 73$

SECTION III - GEOTHERMAL SITE LISTING 135

SECTION IV - ADDITIONAL REGIONAL LISTING 188

SECTION V - SUBJECT IISTING 192

TABLES $\quad 222$

Table 1: Abbreviations used in short references. 223

Table 2: Codes used in short references. 227

Table 3: Listing of geothermal sites in Alaska. 228

Table 4: List of allases. 231

$\begin{array}{ll}\text { FIGURES } & 232\end{array}$

Figure 1. Map of Alaska divided into the 10 geographical regions.

Figure 2. Geothermal spring localities in region referred to as southeastern.

Figure 3. Geothermal spring localities in region referred to as southeast Quadrant.

Figure 4. Geothermal spring localities in region referred to as south central.

Figure 5. Geothermal spring localities in region referred to as southwest Quadrant.

Figure 6. Geothermal spring localities in region referred to as Alaska Peninsula.

Figure 7. Geothermal spring localities in region referred to as eastern Aleutians.

Figure 8. Geothermal spring localities in region referred to as western Aleutians. 
Figure 9. Geothermal spring localities in region referred to as Interior.

Figure 10. Geothermal spring localities in region referred to as Seward Peninsula.

242

Figure 11. Geothermal spring localities in region referred to as Northern.

243

APPENDIX A - MAJOR GEOTHERMAL PROJECTS IN ALASKA

245

APPENDIX B - AGENCIES INVOLVED IN ALASKA GEOTHERMAL

255 


\section{INTRODUCTION - ALASKA GEOTHERMAL BIBLIOGRAPHY}

The Alaska geothermal bibllography is presented in five sections. The first section, pages 5-72, is a standard format alphabetical bibliography which lists all publications, through 1986, that discuss any facet of geothermal energy in Alaska. In addition, selected publications about geology, geophysics, hydrology, volcanology, etc., which discuss areas where geothermal resources are located are included, though the geothermal resource itself may not be mentioned. The bibliography contains 748 entries.

The second section, pages 73-134, is an alphabetical Iisting by author regardless of where the author's name appears in the citation. Each entry gives the first author, year of publication, abbreviated title and codes for subject category. The subject codes are listed in order of emphasis in the article. Table 1 , page 223 , lists the abbreviations most commonly used in the shortened titles. Table 2 , page 227. provides an index of subject codes.

The third section, pages $135-187$, is a listing of references for each of the 123 geothermal sites in alphabetical order. Each main entry gives the site name and identification number. Figure 1, page 233, shows the areas covered by figures 2 through 11 , pages 234-243, on which the locations of the geothermal sites are shown. Table 3 , page 228, provides the identification key. For consistency, geothermal site ID numbers are the same as those used on the NOAA map of Geothermal Resources of Alaska, 1:2,500,000, (Motyka and others, 1983). The map is avallable from the Alaska Division of Geological and Geophysical surveys. Under each geothermal site is a listing of authors; abbreviated titles, and subject codes. Several sites are included which do not appear on the NOAA map. They fall into one of three categorles: 1) sites which have had geothermal manifestations in recent past - eg. Bogoslof; 2) sites which are good candidates for the occurrence of a geothermal resource due to presence of Recent volcanism -eg. Edgecumbe: 3) sites which have been identified since 1983, the map's publication date - eg. Upper Noatak. Early references sometimes used different names for the same site so Table 4, page 231 , 18 included which gives the known aliases.

The fourth section, pages $188-191$, is a supplemental listing of references by geographical region. Figure 1 , page 233, shows the boundarles of the reglons used in this section and Figures 2 through 11, pages 234-243, are enlargements of each region with the geothermal sites indicated. Under each main entry is again, a listing of authors, abbreviated titles, and subject codes. References in this section generally cover a large geographic area and 
are not usually listed in section three under any specific geothermal site.

The fifth section is a listing of references by

subject. Main entries are identical to those listed in Tabie 2, page 227. Under each subject is, as usual, a listing of authors, abbreviated titles and subject codes. The subject heading "Geothermal" contains every reference which specifically mentions a geothermal site regardless of context. Actual geothermal studies are marked " $R$ " in the subject code.

All or any part of this bibliography is available on $51 / 4$ inch computer diskettes, formatted in the MS-DOS operating system. It is avaliable as an ASCII text file or as a set of 4 document (*.DOC) files for use with Microsoft Word. Total storage required is $730 \mathrm{~K}$ with the largest file 360K. The bibllographic data base used to index the references is written in dBASE III and is also available. Total storage requirements for the four DBF files is $790 \mathrm{~K}$ with $490 \mathrm{~K}$ for the largest. Additional hard copies of this 259 page document can be obtained at $\$ 0.10$ per page. 


\section{ALASKA GEOTHERMAL BIBLIOGRAPHY}

\section{SECTION I}

STANDARD BIBLIOGRAPHICAL IISTING 
Ach, J., and DeIong, S. E., 1980, Magmatic evolution of Little sitkin and semisopochnol volcanoes, Alaska [abs.]: EOS, v. 61, p. 1140 .

Adams, D. D., 1983, Geology of the northern contact area of Arrigetch Peaks pluton, Brooks Range, Alaska: Fairbanks, University of Alaska, unpublished M.S. thesis, 86 p.

Adans, D. D., 1984, Geology of the northern contact area of the Arrigetch Peaks pluton, Brooks Range, Alaska [abs.]: Geological Society of America, Cordilieran Section, Abstracts with Programs, v. 16, no. 5, p. 265.

Alaska Geological Consultants, 1975, ERDA Geothermal energy program, Drum Thermal Springs Area: Report of Oct 1975 for AHINA Native Regional corporation.

Allely, R. D., 1986, Interpretation of seismic-refraction profiles at the proposed site for a geothermal power plant, in Updike, R. G., ed., Engineering geology technical feasibility study, Makushin geothermal power project Unalaska, Alaska: Fairbanks, Alaska Division of Geological \& Geophysical Surveys, Public-data File 86-60, p. B15-B20.

Allen, E. T., and Zies, E. G., 1923, A chemical study of the fumaroles of the Katmai region: National Geographic Society, Contributed Technical Papers, Katmai Series, v. 2, p. 75-155.

Andreasen, G. E., Dempsen, W. J., Henderson, J. R., and Gilbert, F. P., 1958, Aeromagnetic map of the Copper River Basin, Alaska: U. S. Geological Survey, Geophysical Investigations Map GP-156, scale 1:125,000.

Andreasen, G. E., Grantz, A., zietz, I., and Barnes, D. F., 1964, Geologic interpretation of magnetic and gravity data in the Copper River basin, Alaska: U. S. Geological Survey Professional Paper 316-H, p. 135-153.

Anma, K., 1971, An aeromagnetic survey in the Valley of Ten Thousand Smokes, Alaska: Fairbanks, University of Alaska, unpublished M.S. thesis, 97 p.

Anonymous, 1953, Activity of Trident Volcano: Volcano Letters, no. 520, p. 5-6.

Anonymous, 1953, Eruption of Trident Volcano, Alaska: Volcano Letters, no. 519, p. 7.

Anonymous, 1975, Alaska Regional Profiles, 1975, v. 3, Southwest Region, sponsored by Alaska with the Joint Federal-state 
Iand Use Planning commission for Alaska: Wheelright Ithography Co., Salt Lake City, 313 p.

Anonymous, 1982, Gates of the Arctic, Reed River Hot Springs: National Park Service, Denver Service Center, Branch of Speclal Programs, Special Report, 19 p.

Arce, G. N., 1983, Volcanic hazards from Makushin Volcano, Northern-Unalaska Island, Alaska: Fairbanks, University of Alaska, unpublished M.S. thesis, 142 p.

Arce, G. N., and Economides, M. J., 1982, Analysis of volcanic hazards from Makushin Volcano, Unalaska Island: Proceedings IV New zealand Geothermal Workshop, p. 93-99.

Bader, J. W., 1984, Geologic map of the Demarcation Point, Mount Michelson, Flaxman Island, and Barter Island quadrangles, Alaska: U. S. Geological survey Open-file Report 84-569, scale $1: 250,000$.

Bader, J. W., and Blrd, K. J., 1986, Geologic map of Demarcation Point, Mt. Michelson, Flaxman Island, and Barter Island quadrangles, N.E. Alaska, Iatitudes 69 deg to 70 deg $45 \mathrm{~min}$ $\mathrm{N}$, Longitudes $141-147 \mathrm{deg}$ W: U. S. Geological Survey Miscelianeous Investigations Map I-1791, I pl., scale $1: 250,000$.

Baker, D. R., and Eggler, D. H., 1983, Fractionation paths of Atka (Aleutlans) hlgh alumina basalt: Constraints from phase relations: Journal of Volcanology and Geothermal Research, v. 18, p. 387-404.

Baker, R. O., Lebida, R. C., Pyle, W. D., and Britch, R. P., 1977, An Investigation of selected Alaska geothermal springs sources as possible salmon hatchery sites: National Technical Information Service IDO/1624-1, $173 \mathrm{p}$.

Barnes, Ivan, and McCoy, G. A., 1979, Possible role of mantlederived $\mathrm{CO} 2$ in causing two "phreatic" explosions in Alaska: Geology, v. 7, p. 434-435.

Barnes, Ivan, and Miller, T. P., 1974, Geothermal studies in Alaska [abs.]: Geological Society of America, Abstracts with Programs, v. 6, no. 7, p. 645-646.

Barnwell, W. W., and Pearson, K. S., 1984, Alaska's Resource Inventory: Fairbanks, Alaska Division of Geological and Geophysical surveys, Special Report $36,59 \mathrm{p}$.

Barrett, S. A., 1978, A three-dimensional magnetic model of Augustine Volcano: Fairbanks, University of Alaska, unpublished M.S. thesis, $175 \mathrm{p}$. 
Barrett, S. A., stone, D. B., and Rienle, J., 1977, A threedimensional model of Augustine Volcano [abs.]: EOS, $v .58$, no. 3, p. 196

Basecu, N., 1980, Geothermal energy in Alaska: Geo-heat Utilization Center Quarterly Bulletin, v. 5, p. 1-3.

Beaglehole, J. C., ed., 1967, The journals of Captain James Cook on his voyages of Discovery III. The voyage of the Resolution and Discovery 1776-1778: Cambridge University Press, Cambridge, 361 p.

Becker, G. F., 1898, Reconnaissance of the goldfields of southern Alaska with some notes on general geology: U. $\mathbf{S}$. Geological Survey 18th Annual Report, Part III, Economic Geology, p. 28-3I, p. 50-58, pl. X.

Beebee, J., and Kirkwood, P., 1979, Unalaska: Prospects for geothermal energy: Energy Systems Inc, report to Alaska Division of Geological and Geophysical Surveys, 12 p.

Beget, J. E., 1986, Prehistoric tephra eruptions, debris avalanches, and tsunamis at Mt. St. Augustine: the geologic record [abs.]: EOS, v. 67 , no. 44, p. 1260.

Beikman, H. M., 1974, Preliminary geologic map of the southeast quadrant of Alaska: U. S. Geological survey Misc. Field studies Map MF-612, scale 1:1,000,000.

Beikman, H. M., 1974, Preliminary geologic map of the southwest quadrant of Alaska: U. S. Geological Survey Misc. Field Studies Map MF-611, scale 1:1,000,000.

Belkman, H. M., 1975, Preliminary geologic map of southeastern Alaska: U. S. Geological Survey Misc. Field studies Map MF673, scale 1:1,000,000.

Beikman, H. M., compller, 1980, Geologic map of Alaska: U. S. Geological survey, scale 1:2,500,000.

Beikman, H. M., and Lathram, E. H., 1976, Preliminary geological map of nothern Alaska: U. S. Geological Survey Misc. Field studies Map MF-789, scale 1:1,000,000

Benson, C. S.; Bingham, D. K., and Wharton, G. B., 1975, Glaciological and volcanological studies at the summit of Mt Wrangell, Alaska: Proceedings of Moscow Snow and Ice Symposium, Aug. 1971, IAHS-AISH Publication no. 104, p. 9598.

Benson, C. S., and Follett, A. B., 1986, Application of photogrammetry to the study of volcano-glacier interactions on Mount Wrangell, Alaska: Photogrammetric Engineering and Remote Sensing, $v .52$, no. 6, p. 813-827. 
Benson, C. S., and Motyka, R. J., 1978, Glacler-volcano Interactions on Mount Wrangell, Alaska: Fairbanks, University of Alaska, Geophysical Institute, Annual Report $1977-78$, p. $1-25$.

Benson, C. S., Motyka, R. J., Bingham, D. K., Wharton, G. B., Mackeith, P., and sturm, M., 1985, Glaclological and volcanological studies on Mt. Wrangell, Alaska, in Kotlyakov, Vinogradov, and Glazovsky, eds., Glaciological Researches No. 27, Soviet Geophysical Committee, Academy of sclences of the U. S. S. R., p. 114-133.

Berg, H. C., Elliott, R. I., Smith, J. G., and Koch, R. D., 1978, Geologic map of the Retchikan and Prince Rupert Quadrangles, Alaska: U. S. Geological survey Open File Report 78-73-A, scale 1:250,000.

Berg, H. C., and Hinckley, D. W., 1963, Reconnaissance geology of northern Baranof Island, Alaska: U. S. Geological Survey Bulletin 1141-0, p. 1-24.

Berg, E., and Kienle, J., 1966, Gravity measurements in the Katmal volcano area, Alaska: Falrbanks, University of Alaska, Geophysical Institute scientific Report UAG R-176, $14 \mathrm{p}$.

Berg, E., Kubota, S., and Kienle, J., 1967, Preliminary determination of crustal structure in the Katmal National Monument, Alaska: Bulletin of the selsmological society of America, v. 57, no. 6, p. 1367-1392.

Berry, G. W., Grim, P: J., and Ikelman, J. A., 1980, Thermal spring list for the United states: NOAA Geophysical Records Document no. $12,60 \mathrm{p}, 2 \mathrm{pl}, \mathrm{scale} 1: 5,000,000$.

Biggar, N. E., 1974, A geological and geophysical study of Chena Hot Springs, Alaska: Fairbanks, University of Alaska, Geophysical Institute, unpublished M.S. thesis, 72 p., 2 pl., scale $1: 31,680$ and $1: 1,250$.

Bingham, D. K., 1967, Ice motion and heat flow studies, Mt. Wrangell, Alaska: Fairbanks, University of Alaska, unpublished M.S. thesis, 117 p.

Bingham, D. K., and Benson, C. S., 1967, Glaclological studies on Mt. Wrange11, Alaska, Part II-Ice motion and heat flow studies: Proceedings 18th Alaska Science Conference.

Bingham, D. K., and Benson, C. S., 1968, Ash temperature varlations on Mt. Wrangell, Alaska: New Zealand Journal of Geology and Geophysics, v. 11, no. 3, p. 781-786. 
Black, R. F., 1974, Geology and anclent Aleuts, Amchitka and Umnak Islands, Aleutians:. Arctic Anthropology, v. 11, no. 2. p. 126-140.

Black, R. F., 1974, Late Quaternary sea level changes, Umnak Island, Aleutians-Their effects on ancient Aleuts and their causes: Quaternary Research, v. 4, p. 264-281.

Black, R. F., 1975, Late Quaternary geomorphic processes: Effects on the ancient Aleuts of Umnak Island in the Aleutians: Arctic, v. 28, no. 3, p. 159-169.

Black, R. F., 1976, Geology of Umnak Island, eastern Aleutian Islands as related to the Aleuts: Arctic and Alpine Research, v. 8, n. 1, p. 7-35.

Black, R. F., 1980, Isostatic, tectonic, and eustatic movements of sea level in the Aleutian Islands, Alaska, in Morner, $N$. A., ed., Earth rheology, isostacy and eustasy: New York, $J$. wiley \& Sons, p. 231-248.

Black, R. F., 1981, Holocene sea level changes in the Aleutian Islands: New data from Atka Island, in Colquhoun, D. J., ed., Holocene sea level fluctuations, magnitude and causes: International Geological Congress Publication no. 61, p. 112 .

Black, R. F., 1981, Late Quaternary climatic changes in the Aleutian Islands, Alaska, in Mahaney, W. C., ed., Quaternary paleoclimate: Norwhich, U. K., Geoabstracts Ltd., p. 47-62.

Black, R. F., 1983, Glacial chronology of the Aleutian Islands, in Thorson, R. M., and Hamilton, T. D., eds., Glaciation in Alaska: Alaskan Quaternary Center, Fairbanks, University of Alaska Museum, Occasional Paper no. 2, p. 5-10.

Blackwell, D. D., steele, J. I., 1986, DNAG Geothermal map of North America [abs.]: EOS, v. 67, no. 44, p. 137.

Blanchard, D. C., and Tailleur, I. I., 1982, Preliminary geothermal isograd map, NPRA, in Coonrad, W. L., ed., The U. S. Geologlcal survey in Alaska: Accomplishments during 1980: U. S. Geological survey Circular 844, p. 46-48.

Bliss, J. P., 1983, Alaska, basic data for thermal springs and wells as recorded in GEOTHERM: $U$. S. Geological survey Open-file Report 83-426, $114 \mathrm{p}$.

Blodgett, R. B., and Gilbert, W. G., 1983, The Cheeneetnuk Ilmestone, a new Early(3) to Middle Devonian formation in the Mc Grath A-4 and A-5 quadrangles, west-central Alaska: Fairbanks, Alaska Division of Geological and Geophysical Surveys, Professional Report 85, 6 p., 1 pl., scale $1: 63,360$. 
mats $\quad \therefore \quad \cdots$

Bordet, P., Marinell1, G., Mittempergher, M., and Tazieff, H., 1963, Contributions a I'etude volcanologique du Ratmai et de la Vallee des Dix Mille Fumees (Alaska): Memolres de la Soclete Geologlque de Belgique, Brussel, Belglum, IN-8 (7), 70 p.

Bordet, P., and Tazleff, H., 1963, Remarks on the eruption of Katmal and the valley of Ten Thousand Smokes and on the problem of ignimbrites: Societe Geologique de France Bulletin, v. 5, no. 2, ser. 7, p. 210-213.

Boyd, T. M., and Jacob, K. H., 1984, Seismicity of the Unalaska region, Alaska: Alaska Division of Geological and Geophysical Surveys report in preparation.

Brew, D. A., and Ford, A. B., 1985, Preliminary reconnaissance geologic map of the Juneau, Taku River, Atilin and part of the Skagway 1:250,000 quadrangles, southeastern Alaska: U. S. Geological Survey Open-file Report $85-395,23$ p., 2 pl., scale 1:250,000.

Brew, D. A., Muffler, I. J. P., and Loney, R. A., 1965, Eruptive history of the Mt. Edgecumbe volcanlc fleld, Kruzof Island, southeastern Alaska [abs.]: Proceedings of the 16th Alaska Science Conference in Juneau, p. 115-116.

Brew, D. A., Muffler, I. J. P., and Ioney, R. A., 1969, Reconnaissance geology of the Mount Edgecumbe Volcanic fleld, Kruzof Island, southeastern Alaska: U. S. Geological Survey Professional Paper 650 D, P. D1-D25.

Brew, D. A., Ovenshine, A. T. Karl, S. M., and Hunt, S. J., 1984, Preliminary reconnaissance geologic map of the Petersburg and parts of the Port Alexander and sumdum 1:250,000 quadrangles, southeastern Alaska: U. $S$. Geological Survey, Open-file Report $84-405,42 \mathrm{p}$., I pl., scale $1: 250,000$.

Brook, C. A., Marlner, R. H., Mabey, D. R., Swanson, J. R., Guffant1, $M_{1}$, and Muffler, I. J. P., 1979, Hydrothermal convection systems with reservolr temperatures $<90$ deg $c$., In Muffler, I. J. P., ed., Assessment of geothermal resources of the United states--1978: U. S. Geological Survey circular 790 , p. 18-85.

Brophy, J. G., and Marsh, B. D., 1984, Petrology and geochemistry of the cold Bay volcanic center, Alaska Peninsula, southwestern Alaska [abs.]: Geological society of America, Abstracts with Programs, v. 15, no. 6, p. 534 .

Brosge, W. P., and Patton, W. W. Jr., 1982, Regional bedrock geologic maps along the Dalton Highway, Yukon crossing to 
Toolik, Alaska: U. S. Geological Survey Open-file Report 82-1071, 5 p., 1 pl. scale 1:500,000.

Brosge, W. P., and Pessell, G. H., 1977, Preliminary Reconnaissance geologic map of the Survey Pass quadrangle: U. S. Geological Survey Open-file Map 77-27, scale $1: 250,000$.

Brown, J. S., 1899, shishaldin as a fleld for exploration: National Geographic Magazine, v. 10, no. 8, p. 281-288.

Buddington, A. F., and Chapin, T., 1929, Geology and mineral deposits of southeastern Alaska: U. S. Geological Survey Bulletin $800,398 \mathrm{p}$.

Bundtzen, T. K., and Gilbert, พ. G., 1983, Outline of geology and mineral resources of upper Kuskoswim region, Alaska: Alaska Geological Society Journal, v. 3, p. 101-118.

Bundtzen, T. K., and Kline, J. T., 1986, Coal, peat, and geothermal potential of the Kuskokwim area plan: Fairbanks, Alaska Division of Geological and Geophysical Surveys, Public-data File 86-88, $13 \mathrm{p}$.

Bunker, C. M., Hedge, C. E., and Sainsbury, C. L., 1977, Radiometric concentrations and preliminary radiometric ages of rocks of the Kigluaik Mountains, Seward Peninsula, Alaska: U. S. Geological Survey Open-file Report 77-735, 36 p.

Burk, C. A., 1965, Geology of the Alaska Peninsula-island arc and continental margin, parts 1,2 , and 3: Geological society of America Memoir 99, 250 p., 3 pl., scale 1:500,000 and $1: 250,000$.

Buzzell, R. G., and Gibson, D. E., 1986, Nome-Taylor Road: Cultural resources survey along mile 21 to mile 68 , seward Peninsula, Alaska: Falrbanks, Alaska Division of Geological and Geophysical Surveys, Public-data File 86-5, 79 p.

Byers, F. M. Jr., 1959, Geology of Umnak and Bogoslof Islands, Aleutian Island, Alaska: U. S. Geological Survey Bulletin 1028-L, p. 107-367.

Byers, F. M. Jr., 1961, Petrology of three volcanic suites, Umnak and Bogoslof Islands, Aleutian Islands, Alaska: Geological Society of America Bulletin, v. 72, p. 93-128.

Byers, F. M. Jr., and Barth, T. F. W., 1948, Geology of Akutan Island, unpublished geologic map and fleld notes: U. $S$. Geological Survey Archives, Menlo Park, California. 
Byers, F. M. Jr., and Barth, T. F. W., 1953, Volcanic activity on Akun and Akutan Islands: Proceedings, 7th Pacific Sclence Congress, 1949, New Zealand, v. 2, p. 382-397.

Byers, F.M. Jr., and Brannock, W. W., 1949, volcanic activity on Umnak and Great Sitkin Islands, 1946-1948: EOS, v. 30, no. 5, p. 719-734.

CadY, W. M., Wallace, R. E., Hoare, J. M., and Weber, F. R., 1955, The central Kuskokwin region, Alaska: U. S. Geological survey, Professional Paper 268, 132 p.

Campbe11, D. A., and Economides, M. J., 1984, A summary of geothermal exploration and data from stratigraphic test well no. 1, Makushin volcano, Unalaska Island, Alaska: Geothermal Resources Counc1l Transactions, v. 8, p. 1-8.

Capps, S. R., 1934, Notes on the geology of the Alaska Peninsula and Aleutian Islands: U. S. Geological Survey Bulletin 857D, p. 141-153.

Capps, S. R., 1935, The southern Alaska Range: U. S. Geological Survey Bulletin 862,101 p.

Carey, D. L., Nicholas, T. J., Huttrer, G. W., Dejong, P. K., and Graback1, S. T., 1983, The Unalaska Geothermal exploration project: Introduction and land, regulatory and environmental aspects: Geothermal Resources counc1l Transactions, v. 7, p. 83-88.

Carrlck, S., and Maurer, M. A., 1986, Hydrology, surface water and water quality, in Updike, R. G., ed., Engineering geology technical feasibility study, Makushin geothermal power project Unalaska, Alaska: Fairbanks, Alaska Division of Geological \& Geophysical surveys, Public-data File 86-60, p. Il-I35, 2 pl, scale 1:24,000.

Carter, I. D., and Galloway, J. P., 1978, Preliminary geologic maps of the proposed natural gas pipeline route in the Tanana River valley, Alaska: U. S. Geological Survey openfile Report $78-794,26$ p., 3,pl., scale 1:125,000

Case, J. E., Detterman, R. I., and Wilson, F. H., 1980, Tertiary volcanic centers on the Alaska Peninsula: U. S. Geological Survey Professional Paper 1175, 111 p.

Cass, J. T., 1959, Reconnalssance geologic map ot the Melozitna quadrangle, Alaska: U. S. Geologlcal survey Miscellaneous geologic Investlgations map $I-290$, scale $1: 250,000$.

Chalgneau, M., and Bordet, P., 1963, Gaz occlus dans les verres de la valiee des DIX Mille Fummees (Ratmai, Alaska):

Academie de sclence, Comptes Reudus, v. 256, p. 3167-3169. 
Chapman, R. M., Yeend, W. E., Brosge, W. P., and Reiser, H. N., 1975, Preliminary geologic map of the Tanana and northeast part of the Kantishna River quadrangles, Alaska: U. $S$. Geological Survey Open-file Report 75-337, 1 pl., scale $1: 250,000$.

Chapman, R. M., Yeend, W. E., Brosge, W. P., and Reiser, H. N., 1982, Reconnaissance geologic map of the Tanana quadrangle:

U. S. Geological survey Open-file Report 82-734, 18 p., I pl., scale 1:250,000.

Church, R. E., Crick, R. W., and Lian, E. B., 1970, Copper River basin stratigraphic correlation section: Alaska Geological society, 2 pl.

clark, G. A., 1912, The Katmal eruption (June 1912): Selsmological Soclety of America Bulletin, v. 2, p. 226-229.

Coats, R. R., 1947, Geology of northern Adak Island: U. $S$. Geological Survey Alaskan Volcano Investigation Report 2 , pt. 5, p. 72-85.

Coats, R. R., 1947, Geology of northern Kanaga Island: $U$. $S$. Geological Survey Alaskan Volcano Investigations Report 2, pt. 6, p. 89-94.

Coats, R. R., 1950, Volcanic activity in the Aleutian arc:

U. S. Geological Survey Bulletin 974-B, p. 1-47.

Coats, R. R., 1952, Magmatic differentiation in Tertiary and Quaternary volcanic rocks from Adak and Kanaga Islands, Aleutian Islands, Alaska: Geological Society of America Bulletin, v. 63, p. 486-514.

Coats, R. R., 1953, Geology of Buldir Island, Aleutian Islands, Alaska: U. S. Geological Survey Bulletin 989-A, p. 1-26.

Coats, R. R., 1956, Geology of Northern Adak Island, Alaska:

U. S. Geological Survey Bulletin 1028-C, p. 45-67.

Coats, R. R., 1956, Geology of northern Kanaga Island, Alaska:

U. S. Geological Survey Bulletin 1028-D, p. 69-81.

Coats, R. R., 1956, Reconnaissance geology of some western Aleutian Islands, Alaska: U. S. Geological Survey Bulletin 1028-E, p. 82-100.

Coats, R. R., 1959, Geological reconnaissance of Gareloi Island, Aleutian Islands, Alaska: U. S. Geological Survey Bulletin 1028-J, p. 249-256.

Coats, R. R., 1959, Geological reconnaissance of Semisopochnoi Island, western Aleutian Islands, Alaska: U. S. Geological Survey Bulletin 1028-0, p. 447-519. 
Coats, R. R., 1962 , Magma type and the crustal structure in the Aleutian arc, in Macdonald, G. A., and Kuno, H.; eds., The crust of the Pacific basin: American Geophysical Union Monograph 6, p. 92-109.

Coats, R. R., and Marsh, B. D., 1984, Reconnaissance geology and petrology of northern Tanaga, Aleutian Islands, Alaska [abs.]: Geological Society of America, Abstracts with Programs, v. 16, p. 474.

Coats, R. R., NeIson, W. H., Lewis, R. Q., and Powers, H. A., 1961, Geologic reconnaissance of Kiska Island, Aleutian Islands, Alaska: U. S. Geological survey Bulletin 1028-R, p. 563-581.

Collazzi, E. J., and Ireland, R. R. W., 1986, Hydrologic reconnaissance of the Kuskokwim River basin between Sleetmute and Anlak, Alaska 1982-1983: Falrbanks, Alaska Division of Geological and Geophysical surveys, Public-data File 86-16, I pl., scale 1:385,000.

Collier, A. J., 1902, A reconnalssance of the northwestern portion of the Seward Peninsula, Alaska: U. S. Geological Survey Professional Paper 2, $70 \mathrm{p}, .12 \mathrm{pl}$.

Combellick, R. A., 1986, Engineering geology of the proposed site for a geothermal power plant on Unalaska Island, Alaska, In Updike, R. G., ed., Englneering geology technical feasibility study, Makushin geothermal power project Unalaska, Alaska: Fairbanks, Alaska Division of Geological \& Geophysical Surveys, Public-data F1le 86-60, p. BI-BI4, 2 pl., scale 1:480.

Conrad, W. K., and Kay, R. W., 1984, Ultramafic and maflc inclusions from Adak Island: Crystallization history and implications for the nature of primary magmas and crustal evolution in the Aleutian arc: Journal of Petrology, v. 25, p. 88-125.

Conwell, C. N., and Schell, L. C., 1977, Energy Resource Map of Alaska: Fairbanks, Alaska Division of Geological and Geophysical Surveys, scale 1:2,500,000.

Corwin, R. F., and Fitterman, D. V., 1983, Self potential survey results - Makushin volcano geothermal area, Unalaska Island, Alaska: Geothermal Resources Council Transactions, v. 7, p. 89-94.

Curtis, G. H., 1955, Importance of Novarupta during eruption of Mt. Ratma1, Alaska in 1912 [abs.]: Geological Society of America Bulletin, v. 66, p. 1547. 
Curtis, G. H., 1968, The stratigraphy of the ejecta of the 1912 eruption of Mount Ratmal and Novarupta, Alaska: Geological Soclety of America, Memoir 116, p. 153-210.

Daily, I. M., 1912, Report on the eruption of Ratmai volcano: Geological Society of America Bulletin, v. 44, p. 641-644.

Daley, E. E., 1986, Petrology, geochemistry, and the evolution of magmas from Augustine Volcano, Alaska: Fairbanks, University of Alaska, unpublished M.S. thesis, 103 p.

Daley, E. E., and Swanson, S. E., 1985, Low pressure fractionation in arc volcanoes: An example from Augustine Volcano, Alaska [abs.]: Geological Society of America, Abstracts with Programs, v. 17, no. 7, p. 558.

Dall, W. H., 1870, Alaska and its reources: Lee and Shepard, Boston, 627 p. (Reprinted in 1970 by Arno \& New York Times Press, American Environmental studies series.)

Dall, W. H., 1870, The new Bogosloff volcano: Science, $v .4$, no. 80, p. $138-139$.

Da11, W. H., 1884, New volcano 1sland in Alaska: Sclence, V. 3, no. 51, p. $89-93$.

Dall, W. H., 1885 Further notes on Bogoslof 1sland: sclence, v. 5, no. 101, p. 32-33.

Dames and Moore, 1980, Geothermal drilling studies near Unalaska, Alaska: Unpublished final report submitted to state of Alaska, Division of Energy and Power Development, Anchorage, 5 p.

Davidson, G., 1884, The new Bogoslof volcano in Bering Sea: science, v. 3 , no. 57 , p. 282-286.

Davidson, G., 1884, Notes on the volcanic eruption of Mount st. Augustine, Alaska, Oct. 6, 1883: Sclence, v. 3, no. 54, p. 186-189.

Davidson, G., 1884, The first ascent of the Volcano Makushin: Appalachia, v. 4, no. $1, \mathrm{p} .1-11$.

Davidson, G., 1884, A new volcano island in Alaska: Science, $v$. 3 , no. 51, p. 89-92.

Davidson, G., 1893, The eruption of Volcano Weniaminof: Geographical society of the Pacific, Transactions and Proceedings, v. 3, p. 59-63.

Davies, J. N., 1986, Seismic hazards constraints, in Updike, R. G., ed., Engineering geology technical feasibility study, Makushin geothermal power project Unalaska, Alaska: 
Fairbanks, Alaska Division of Geological \& Geophysical Surveys, Public-data File 86-60, p. M1-M28.

Davies, J. N., and Kienle, J., 1986, The 1986 eruption of Mt. st. Augustine, Alaska: A case study in the successes and fallures of scientific advice during a volcanic crisis [abs.]: EOS, v. 67, no. 44, p. 1259.

Davydov, G. L., 1809, Two voyages to Russian America 1802-1807: Bearne, C, translator, Plerce, R. A., ed., Ilmestone Press, 1977, Kingston, Ontario, Canada, 258 p.

Dean, K. G., Forbes, R. B., Turner, D. L., and Eaton, F. D., 1981, Application of radar and Infrared alrborne remote sensing to geothermal resource assessment at Pilgrim Springs, Alaska: Fairbanks, University of Alaska, Geophysical Institute, final report submitted to NASA (Grant NAG9-8), 21 p.

Decker, J., 1980, Geology of a Cretaceous subduction complex western Chichagof Island, southeastern Alaska: Stanford University, stanford California, unpublished Ph.D. thesis, 135 p., I pl., scale $1: 63,360$.

Decker, J., 1980, Geologic map of western Chichagof Island, southeastern Alaska: U. S. Geological survey Open-file Report $80-150,2$ pl., scale 1:63,360.

Decker, J., 1984, The Kuskokwim group: A post-accretionary successor basin in southwest Alaska [abs.]: Geological Soclety of America, Abstracts with programs, v. 16, no. 5, p. 277.

Decker, J., and Hoare, J. M., 1982, Sedimentology of the Cretaceous Kuskokwim Group, southwest Alaska, in Coonrad, w. L., ed., The U. S. Geological survey in Alaska: Accomplishments during 1980: U. S. Geological survey Circular 844, p. 81-82.

Decker, J., Reifenstuhl, R. R., and Coonrad, W. L. 1984, Compilation of geologic data from the Russian Mission $A-3$ quadrangle: Fairbanks, Alaska Division of Geological and Geophysical Surveys, Report of Investigation 84-19, 1 pl., scale $1: 63,360$.

Decker, J., Reifenstuhl, R. R., and Coonrad, W. L., 2984, Compilation of geologic data from the sleetmute B-5 quadrangle, southwestern Alaska: Fairbanks, Alaska Division of Geological and Geophysical Surveys, Public-data File 8444.

Decker, R. W., 1964, Geophysical investigations in Katmai National Monument, Alaska [abs.]: EOS, v. 45, p. 124. 
Decker, R. W., 1967, Investigations at active volcanoes: EOS, v. 48, n. 2, p. 639-647.

Denig-Chakroff, D. N., 1985, Unalaska/Dutch Harbor reconnaissance study findings and recommendations: Report for the Alaska Power Authority, 199 p.

Denig-Chakroff, D. N., Reeder, J. W., and Economides, M. J., 1985, Development potential of the Makushin geothermal reservoir of Unalaska Island, Alaska: Geothermal Resources Council Transactions, v. 6 , part I, p. 177-182.

Detterman, R. L., 1968, Recent volcanic activity on Augustine Island, Alaska: U. S. Geological Survey Professional Paper 600-c, p. C126-c129.

Detterman, R. I., 1973, Geologic map of the Iliamna B-2 guadrangle, Augustine Island, Alaska: U. S. Geological Survey Map GQ-1068, scale 1:25,000.

Detterman, R. I., Case, J. E., Wllson, F. H., Yount, M. E., and Allaway, w. H. Jr., 1983, Generalized geologic map of the Ugashik, Bristol Bay, and part of the Karluk quadrangles, Alaska: U. S. Geological Survey Miscellaneous Field studies Map MF-1539-A, scale 1:250,000.

Detterman, R. I., and Hartsock, J. K., 1966, Geology of the Iniskin-Tuxedini region, Alaska: U. S. Geological Survey Professional Paper 512, 78 p.

Detterman, R. L., Hudson, T. L., Plafker, G., Tysdal, R. G., and Hoare, J. M., 1976, Reconnaissance geologic map along Bruin Bay and Lake clark faults in Kenal and Tyonek quadrangles, Alaska: U. S. Geological Survey Open-file Report 76-477, 4 p., 1 pl.

Detterman, R. L., Miller, T. P., Wilson, F. H., and Yount, M. E., 1985, Geologic map of the Ugashik and western Karluk quadrangles, Alaska: U. S. Geological Survey Miscellaneous Geological Investigations Map I-685, scale 1:250,000.

Detterman, R. L., Miller, T. P., Yount, M. E., and Wilson, F. H., 1979, Generalized geologic map of Chignik and sutwik Island quadrangles, Alaska: U. S. Geological survey Miscellaneous Investigations Series Map I-1053, scale $1: 250,000$.

Detterman, R. I., Miller, T. P., Yount, M. E., and Wilson, F. H., 1981, Geologic map of the Chignik and sutwik Island quadrangles, Alaska: U. S. Geological Survey Miscellaneous Geological Investigations Map I-1229, scale 1:250,000.

Detterman, R. L., Miller, T. P., Yount, M. E., and Wilson, F. H., 1981, Quaternary geologic map of the Chignik and Sutwik 
Island quadrangles, Alaska: U. S. Geologlcal Survey Miscellaneous Geological Investigations Map I-1292, scale $1: 250,000$

Detterman, R. I., W1Ison, F. H., Yount, M. E., and M1IIer, T. P. 1986, Quaternary geologic map of the Ugashik, Bristol Bay and part of the Karluk quadrangles, Alaska: U. $S$. Geological survey Miscellaneous Field Investigations Map I1801, scale 1:250,000.

Detterman, R. I., and Reed, B. I., 1964, Preliminary map of the geology of the Illamna quadrangle, Alaska: U. S. Geological Survey Miscellaneous Geological Investigations Map I-407, scale $1: 250,000$.

Detterman, R. I., and Reed, B. I., 1968, Geology of the Iliamna quadrangle, Alaska: U. S. Geologlcal Survey Open-flle Map $68-72,2$ pl., scale 1:200,000.

Detterman, R. I., and Reed, B. I., 1973, Surficial deposits of the Iliama quadrangle, Alaska: U. S. Geologlcal Survey Bulletin, 1368-A, P. Al-A64.

Detterman, R. I., and Reed, B. I., 1980, stratigraphy, structure, and economic geology of the Illamna quadrangle, Alaska: U. S. Geological Survey Bulletin 1368-B, 86 p. 1 pl., scale $1: 250,000$.

Dickey, D. B., 1983, Tertiary sedimentary rocks and tectonic implications of the Farewell fault zone, McGrath quadrangle, Alaska: Fairbanks, University of Alaska, unpublished M.S. thesis, $54 \mathrm{p}$.

Dickey, D. B., 1984, Cenozolc non-marine sedimentary rocks of the Farewell fault zone, McGrath quadrangle, Alaska: Sedimentary Geology, v. 38, p. 443-463.

Dickey, D. B., GIlbert, W. G., and KIIne, J, T., 1982, Cenozolc nonmarine sedimentary rocks and structure of the Farewell fault segment of the Denali fault system, southwest Alaska [abs.]: Geological society of America, Abstracts with Programs, p. 166.

Diller, J. S., 1884; Volcanic sand which fell at Unalaska, Alaska, Oct. 20,1883 , and some considerations concerning 1ts composition: science, v. 3, p. 651-654.

Diller, J. S., 1893, Our youngest volcano: National Geographic Magazine, v. 5, p. 93-96.

Dilion, J. T., Adams, D. D., and Adler, P., 1983, Geologic map of the Melozitna A-4 quadrangle: Falrbanks, Alaska Division of Geological and Geophysical Surveys, Report of

Investigations $83-18,1$ pl., scale $1: 63,360$. 
Dixon, J. P., and Pulpan, H., 1986, Crustal structure in the area of the 1985 Dall City, Alaska earthquake sequence [abs.]: EOS, v. 67, no. 44, p. 1198.

Doroshin, P., 1870, some volcanoes, their eruptions, and earthquakes in the former Russian holdings in America: Verhandlungen der Russisch-Kaiserlichen Mineralogischen Geselischaft zu st. Petersburg, zweite Serle, Funfter Rand: 25-44 (in Russian).

Dover, J. H., and Mayaoka, R. T., 1985, Major rock packages of the Ray Mountains, Tanana and Betties quadrangles, in Bartsch-Winkler, S., and Reed, K. M., eds., U. S. Geological Survey in Alaska: Accomplishments during 1983: U. S. Geological Survey Circular 945, p. 32-36.

Drewes, H., Fraser, G. D., snyder, G. I., and Barnett, H. F. Jr. 1961, Geology of Unalaska Island and adjacent insular shelf, Aleutian Islands, Alaska: U. S. Geologlcal Survey Bulletin 1028-s, p. 583-676.

Dumond, D. E., 1979, People and pumice on the Alaska Peninsula, in Sheets, P. D., and Grayson, D. K., eds., Volcanic activity and human ecology: . New York, Academic Press, p. 373-392.

Dunn, R., 1909, Conquering our greatest volcano: Harpers Monthly Magazine, v. 82, no. 3, p. 497-509.

Eakins, G. R., 1969, A sulfur deposit, stepovak Bay, Alaska Peninsula [abs.], in Alaska Division of Mines and Geology, Report for the 1969: Fairbanks, Alaska Division of Mines and Minerals, p. 10.

East, J. S., 1982, Preliminary geothermal investigations at Manley Hot springs, Alaska: Fairbanks, University of Alaska, Geophysical Institute Report UAG-290, 76 p.

East, J. S., 1982, Geothermal investigation of Manley Hot Springs, Alaska: Fairbanks, University of Alaska, unpubilshed M.S. thesis, 95 p.

Eberlein, G. D., Churkin, M. Jr., Carter, C., Berg, H. C., and Ovenshine, A. T., 1983, Geology of the Craig quadrangle, Alaska: U. S. Geological survey Open-file Report 83-91, 53 p., 1 pl., scale 1:250,000.

EberleIn, G. D., Gassaway, J. S., and Belkman, H. M., 1977, Preliminary geologic map of central Alaska: $U$. $S$. Geological survey, Open-file Map 77-168A, 1 pl., scale $1: 1,000,000$. 
Economides, M. J., Ansari, J., Arce, G. N, and Reeder, J. W., 1982, Engineering and geological analyses of the geothermal energy potential of selected sites in the state of Alaska: Proceedings of VIII Workshop on Geothermal Reservoir Engineering, stanford University, $7 \mathrm{p}$.

Economides, M. J., and Arce, G. N., 1983, Geothermal development in Alaska - an englneering and geologic analysis: Geothermics, v. 3, p. 241-264.

Economides, M. J., Economides, C. E., Kunza, J. F., and Lofgren, B. E., 1982, A field-wide reservoir engineering analysis of the Pilgrim Springs, Alaska geothermal reservoir: Proceedings, 8th Workshop in Geothermal Reservoir Englneering, stanford University, stanford, California.

Economides, M. J., Morris, C. W., and Campbe11, D. A., 2985, Evaluation of the Makushin geothermal reservolr, Unalaska Island: Proceedings of the Tenth Workshop on Geothermal Reservoir Engineering, SGP-TR-84, Stanford University, stanford, Ca., p. 227-232.

Economides, M. J., Reeder, J. W., and Markle, D. R., 1981, Unalaska geothermal development: Proceedings of New zealand geothermal workshop, University of Auckland and the New zealand Ministry of Works, p. 7-12.

Edsal1, D. W., 1976, Trace elements in tephra as indicators of magmatic composition in the Aleutian arc: Geological Soclety of America Bulletin, v. 87, p. 1269-1272.

Eickelberger, J. C., and Hildreth, W., 1986, Research drilling at Katma1, Alaska [abs.]: EOS, v. 67, no. 41, p. 778-780.

Emanuel, R. P., 1984, Hydrologic and volcanic hazards from the Mount Spurr, Alaska [abs.]: Geological society of America, Abstracts with Programs, $v .16$, no. 5, p. 281.

Emery, P., and Jones, S., 1984, Hydrologic atlas of the Copper River Basin, Alaska: U. S. Geological Survey - Hydrologic Atlas 686 .

Emmel, K. S., and Coonrod, P. I., 1982, Geological I1terature on the Copper RIver basin and middle Tanana River basins: Fairbanks, Alaska Division of Geological and Geophysical Surveys Special Report $30,11 \mathrm{p}$.

Escher, B. G., 1922, On the hot "lahar" (mud flow) of the valley of Ten Thousand Smokes, Alaska: Koninkl1jke Akademie van Wetenschappen, Proceedings sclence section, v. 24, p. 282293.

Estes, S. A., 1978, Selsmotectonic studies of lower cook Inlet, Kodlak Island and the Alaska Peninsula areas of Alaska: 
Fairbanks, University of Alaska, unpublished M.S. thesis, $142 \mathrm{p}$.

Federman, A. N., and scheidegger, K. F., 1984, Compositional heterogeneity of the distal tephra deposits from the 1912 eruption of Novarupta, Alaska: Journal of Volcanology and Geothermal Research, v. 21, p. 233-254.

Fenner, C. N., 1920, The Ratmal region, Alaska, and the great eruption of 1912: Journal of Geology, v. 28, no. 7, p. 569606 .

Fenner, C. N., 1920, Geology of the Katmal region, Alaska, and the great eruption of 1912 [abs.]: Geologlcal soclety of America Bulletin, v. 31, no. 1, p. 140.

Fenner, C. N., 1923, The origin and mode of emplacement of the great tuff deposit of the Valley of Ten Thousand smokes: National Geographic Society, Contributed Technical Papers, Ratmai Series, no. 1, $74 \mathrm{p}$.

Fenner, C. N., 1923, The origin and mode of emplacement of the great tuff deposit in the Valley of Ten Thousand Smokes: science, v. 57, p. 496-497.

Fenner, C. N., 1926, The Katmal magmatic province: Journal of Geology, v. 34, p. 673-772.

Fenner, C. N., 1930, Mount Ratmai and Mount Mageik: Zeitschrift fur vulkanologle, v. 13, p. 1-24.

Fenner, C. N., 1937, Tuffs and other volcanic deposits of Katmai and Yellowstone Park: EOS, 18th Annual Meeting, Part 1, p. 236-239.

Fenner, C. N., 1950, The chemical kinetics of the Katmal eruption: American Journal of Science, $v .248, n .9, p$. 593-627, (part 1), v. 248, n. 10, p. 697-725, (part 2).

Ferrians, O. J. Jr., and Nichols, D. R., 1965, Copper River basin, in Pewe, T. I. Others, eds., Guide book for field conference $F$, International association for Quaternary Research, Fairbanks, 1965: Academy of Science, Iincoln, Nebraska, p. 93-114.

Ferrians, O. J. Jr., Nichols, D. R., and Schmoll, H. R., 1958, Pleistocene volcanic mudflow in the Copper River basin, Alaska: Geological Society of America Bulletin, v. 69, no. 12, pt. 2, p. 1563.

Ferrians, O. J. Jr., Nichols, D. R., and Williams, J. R., 1983, Copper River Basin, in Pewe, T. R., and Reger, R. D., eds., Richardson \& Glenn Hwy, Alaska, Guidebook to Permafrost and 
Quaternary Geology: Alaska Division of Geological \& Geophysical surveys, Guidebook 1, p."137-175.

Ferrians, O. J. Jr., and Schmoll, H. R., 1957, Extensive proglacial lake of Wisconsin age in the Copper River basin, Alaska: Geological Society of America Bulletin, v. 68, no. 12, pt. 2, p. 1726 .

Fierstein, J. E., and Hildreth, w., 1984, Grain-size of pyrocalstic deposits of Novarupta, Katmal National Park, Alaska [abs.]: EOS, v. 65, no. 45, p. 1149.

Flerstein, J. E., and Hildreth, W., 1986, Ejecta dispersal and dynamics of the 1912 eruptions of Novarupta, Katmal National Park, Alaska [abs.]: EOS, v. 67, no. 44, p. 1246.

Finch, R. H., 1935, Akutan volcano: Zeltschrift fur Vulkanologie, v. 16, no. 3, p. 155-160.

Fitch, E., 1927, Mineral waters of the United States \& American spas: Lea \& Febiger, Philadelphia, Pa. 799p.

Forbes, R. B., 1975, Geothermal energy and wind power... alternate energy sources for Alaska: Fairbanks, University of Alaska Geophysical Institute and Alaska Energy office Report, 144 p., 7 appendices.

Forbes, R. B., ed., 1976, Geothermal energy and wind power alternative energy sources for Alaska: Fairbanks, Geophysical Institute report to National science Foundation.

Forbes, R. B., 1979, A geological and geophysical assessment of the geothermal potential of Pilgrim Springs, Alaska: Fairbanks, University of Alaska, Geophysical Institute Report, $39 \mathrm{p}$.

Forbes, R. B., and Blggar, N. E., 1973, Alaska's geothermal resource potential: Northern Engineer, v. 5, no. 1, p. 610 .

Forbes, R. B., Gedney, L., Van Wormer, D., and Hook, J., 1975, A geophysical reconnaissance of Pilgrim Springs, Alaska: Fairbanks, University of Alaska, Geophysical Institute, Technical Report UAG-231, $26 \mathrm{p}$.

Forbes, R. B., and Kienle, J., 1971, Petrology of pre-1912 pyroclastic deposits in the Valley of 10,000 smokes, Alaska [abs.]: Proceedings International Union of Geodesy and Geophysics - International Association for Volcanology and Chemistry of the Earth's Interior: Symposium on Acid Volcanism, Moscow, USSR, Aug 1971.

Forbes, R. B., and Kienle, J., 1971, Mount Saint Augustine -restless volcano: Pacific Search, v. 6, p. 3-4. 
Forbes, R. B., Kienle, J., and Harlow, D. H., 1971, Microseismicity of Augustine Volcano, Alaska [abs.]: Proceedings International Union of Geodesy and Geophysics International Association for Volcanology and Chemistry of the Earth's Interior: Symposium on Acid Volcanism, Moscow, USSR, Aug. 1971.

Forbes, R. B. Leonard, I. E., and Dinkel, D. H., 1975, Total energy utilization potential of Alaskan thermal springs: Proceedings of the United Nations Geothermal Symposium, San Francisco, California, May 1975, p. 2209-2215.

Forbes, R. B., Leonard, L. E., and Dinkel, D. H., 1975, Utilization of geothermal energy resources in rural Alaska communities: Fairbanks, University of Alaska, Geophysical Institute Report UAGR-232, $83 \mathrm{p}$.

Forbes, R. B., Tumer, D. L., and Naeser, C. W., 1975, Downhole fission track $40 \mathrm{~K} / 40 \mathrm{Ar}$ age determinations and the measurement of perturbations in the geothermal gradient [abs.]: International conference on Geothermometry and Geobarometry, Pennsylvania state University, Extended abstracts volume 1975 .

Forbes, R. B., Turner, D. I., Naeser, D. W., and Hawkins, D. B., 1977. Downhole fission track 40K/40Ar age determinations and the measurement of perturbations in the geothermal gradient: Fairbanks, University of Alaska, Geophysical Institute progress report RDL-229-T11-1 to ERDA under contract No.\# $(45-1)-229$, Task Agreement 11, $37 \mathrm{p}$.

Forbes, R. B., Wescott, E. M., Osterkamp, T. E., Kienle, J., Turner, D. I., and Rline, J. T., 1979, The Pilgrim Springs hydrothermal system: Theories and models: Proceedings of 3oth Alaska Science Conference, American Association for the Advancement of science, p. 60-61.

Forbes, R. B., Wescott, E. M., Turner, D. L., Rienle, J., Osterkamp, T. E., Hawkins, D. B., Kline, J. T. , Swanson, S. E., Reger, R. D., and Harrison, 1979, A geological and geophysical assessment of the geothermal potential of Pilgrim Springs, Alaska: Fairbanks, University of Alaska, Geophysical Institute Report, 39 p., 1 pl.

Foresman, J. B., 1968, Photogeologic and geomorphic study of the Copper River basin, Alaska: Surface Projects section, Phillips Petroleum Co. Job No. P-2094.

Foresman, J. B., 1970, Mud volcanoes and abnormal pressure, Copper River basin, Alaska: Tulsa; Oklahoma, University of TuIsa, unpublished M.S. thesis, $39 \mathrm{p}$. 
Foster, H. L., 1970, Reconnaissance geologic map of the Tanacross quadrangle, Alaska: U. S. Geologlcal Survey, Miscellaneous Geological Investigations Map I-593, 1 pl., scale 1:250,000.

Foster, H. I., Brabb, E. E., Weber, F. R., and Forbes, R. B., 2970, Regional geology of Yukon-Tanana Upland, Alaska [abs.]: American Association of Petroleum Geologists Bulletin, v. 54, no. 12, p. 2481.

Foster, H. I., Iaird, J., Keith, T. E. C., Cushing, G. W. , and Menzie, W. D., 1983, Preliminary geologic map ot the circle quadrangle, Alaska: U. S. Geological Survey open-file Report 83-170-A, 24 p., l pl., scale 1:250,000.

Foster, H. I., Iaird, J., Keith, T. E. C., Cushing, G. W., and Menzie, W. D., 1983, Preliminary geologic map of the circle quadrangle, Alaska: U. S. Geological Survey open-file Report 83-170A, I pl., scale 1:250,000.

Foster, H. L., Weber, F. R., Forbes, R. B., and Brabb, E. E., 1973, Regional geology of Yukon-Tanana Upland, Alaska, in Arctic Geology: American Association of Petroleum Geologists, Memoir no. 19, p. 388-395.

Fournelle, J., and Marsh, B. D., 1986, Shishaldin.Volcano, Unimak Island, Aleutians: Unordinary arc lavas. I. Chemistry, mineralogy and petrology [abs.]: EOS, v. 67, no. 44, p. 1276.

Fraser, G. D., and Barnett, H. F. Jr., 1959, Geology of the Delarof and westernmost Andreanof Islands, Aleutian Islands, Alaska: U. S. Geological Survey Bulletin 1028-I, p. 211248 .

Fraser, G. D., and Snyder, G. I., 1959, Geology of southern Adak Island and Kagalaska Island, Alaska: U. S. Geological

Survey Bulletin 1028-M, p. 371-408.

Fry, W. H., 1912, Mineral content of volcanic ashes from Kodiak (Alaska): Sclence, v. 36, p. 681-682.

Funk, J. M., 1973, Late Quaternary geology of Cold Bay, Alaska, and vicinity: Storrs, Connecticut, university of Connecticut, unpublished M.S. thesis, 45 p.

Funk, J. M., 1973, The late Quaternary history of Cold Bay, Alaska and its implications to the configuration fo the Bering Land Bridge [abs.]: Geological society of America, Abstracts with programs, v. 5, no, $2, p, 162$.

Furst, J. I., 1968, The reconnalssance petrology of andesites from the Mt. Wrangell caldera: Fairbanks, University of Alaska, unpublished M.S. thesis, 83 p. 
Gassaway, J. S., and Abramson, B. S., 1977, Map and table showing distribution of known thermal springs in selected igneous rocks in central Alaska: U. S. Geological survey Open-file Report 77-168H, scale 1:1,000,000.

Gates, O., Powers, H. A., and Wilcox, R, E., 1971, Geology of the Near Islands, Alaska: U. S. Geological survey Bulletin 1028-U, p. 709-782.

Gedney, I., Matteson, C., and Forbes, R. B., 1970, Selsmic refraction profiles of the ash flow in the valley of 10,000 Smokes, Katmal National Monument, Alaska: Journal of Geophysical Research, v. 75, p. 2619-2624.

Gilbert, W. G., 1981, Preliminary geologic map and geochemical data, Cheeneetnuk River area, Alaska: Falrbanks, Alaska Division of Geological and Geophysical Surveys, Open-file Report 153, 10 p., 2 pl., scale $1: 63,360$.

Gilbert, W. G., and Solie, D. N., 1983, Preliminary geologic map of Mc Grath A-3 quadrangel, Alaska: Fairbanks, Alaska Division of Geological and Geophysical Surveys, Report of Investigation 83-7, 1 pl., scale 1:40,000.

Godwin, I, H. Haigler, L. B., Rioux, R. L., White, D. E., Muffler, I. J. P., and Wayland, R. G., 1971, Classification of public lands valuable for geothermal steam and associated geothermal resources: U. S. Geological Survey Circular 647, $18 \mathrm{p}$.

Gosink, T., Borchert, M., and Chuà, R., 1986, Mt. st. Augustine ash, March, 1986: Differerences between aerosol and surface materials [abs.]: EOS, v. 67, no. 44, p. 1260.

Gosink, J. P., and Osterkamp, T. E., 1980, A preliminary investigation of the possible existence of a hot water aquifer under the Pilgrim River: Fairbanks, University of Alaska, Geophysical Institute Report to Alaska Division of Energy and Power Development, $44 \mathrm{p}$.

Grantz, A., White, D. E., Whitehead, H. C., and Tagg, A. R., 1962, Saline springs, Copper River lowland, Alaska: American Association of Petroleum Geologists Bulletin, v. 46, no. 11, p. 1990-2002.

Grewingk, C., 1850, Beitrag zur Kenntnisse der orographischen und geognostischen Beschaffenheir de Nordwest-Kuste Amerikas mit den aliegenden Inseln: Verhandlungen der RussichKaiserlichen Mineralogischen Gesellschalt zur st. Petersburg, Jahrgan 1848 ung 1849, p. 76-342.

Griggs, R. F., 1917, The Valley of Ten Thousand Smokes: National Geographic society explorations in the Katmai 
district of Alaska: National Geographic Magazine, v. 31, no. 1 , p. 13-68.

Griggs, R. F., 1918, the great hot mud flow of the Valley of Ten Thousand Smokes: Ohto Journal of Science, v. 19, p. 117142.

Griggs, R. F., 1918, The Valley of Ten Thousand Smokes: An account of the discovery and exploration of the most wonderful volcanic region in the world: National Geographic Magazine, v. 33, no. 2, p. 115-169.

Griggs, R. F., 1918, The eruption of Katma1: Nature, v. 101, no. 25, p. $497-499$.

Griggs, R. F., 1919, The character of the eruption [of Katmai] as indicated by its effects on nearby vegetation: Ohio Journal of Sclence, v. 19, p. 173-209.

Griggs, R. F., 1919, The Katmai National Monument and the Valley of Ten Thousand Smokes: Science, v. 49, p. 236-237.

Griggs, R. F., 1921, The Katmal National Monument and the Valley of Ten Thousand Smokes: : Science, v. 49, p. 236-237.

Griggs, R. F., 1921, our greatest national monument: The National Geographic society conpletes its explorations in the Valley of Ten Thousand Smokes: National Geographic Magazine, v. 40, no. 3, p. 219-292.

Griggs, R. F., 1922, The Valley of Ten Thousand Smokes: National Geographic Soclety, Washington, $340 \mathrm{p}$.

Griggs, R. F., 1923, Observations on the incandescent sand flow of the Vailey of Ten Thousand Smokes: Koninklijke Akademie van Wetenschappen, Amsterdam, Proceedings Ser. Science, v. 25, p. 42-50.

Hamilton, T. D., 1973, Geomorphic role of snow and ice during the Katmal eruption [abs.]: Geological Society of America, Abstracts with Programs, v. 5, no. 1, p. 48-49.

Hansen, E., Sherman, G., and Knaebel, J., 1981, Prellminary report on the mineral potential of the Alaskan Peninsula: U. S. Bureau of Mines, Open-file Report $36-81,38 \mathrm{p}$.

Harmon, R. S., Nehring, N. L., Motyka, R. J., White, I. D., and Borthwick, J., 1982, Hydrogen and oxygen isotope composition of fumarole condensates from the Augustine Volcano, Alaska: International Association of Geochemistry and cosmochemistry, Fourth International symposium on water-Rock Interaction, October 1982. 
Harmon, R. S., Strong, D. F., Hoefs, J., and Moorbath, S., 1984, Augustine volcano, Alaska: Chemical and isotopic character [abs.]: Geological Society of America, Abstracts with Programs, v. 16, p. 530 .

Harrison, W., and Hawkins, D. B., 1980, Water and heat flow measurements and their relationship to power estimates at Pilgrim Springs, Alaska, in Turner, D. $\mathrm{L}$, , and Forbes, R. B., eds., A geological and geophysical study of the geothermal potential of Pilgrim Springs, Alaska: Fairbanks, University of Alaska, Geophysical Institute, Report UAG-R271, p.101-112.

HawkIns, D. B., and Harrison, W. , 1979 , Measurement of flow rate of Pligrim Hot springs and estimation of ground water velocity in the upper 10 meters of unconsolidated sediments [abs.]: Proceedings 30th Alaska science Conference, American Association for the Advancement of Sclence, p. 57 .

Hawkins, D. B., and Motyka, R. J., 1985, A multivariate statistical analysis and chemical mass balance analysis of waters of the Copper River basin, Alaska, in Wallick, E.. and H1tchon, B., eds., Proceedings of 1st Annual CanadianAmerlcan Conference on Hydrogeology: Banff, Alberta, National Water-well Association, p. 238-249.

Henning, R. A., Olds, B., and Rennick, P., 1981, Wrangell-Saint Elias International Mountain Wilderness: Alaska Geographic, v. 8 , no. 1 , 144 p.

Henning, R. A., Rosenthal, C. H., Olds, B., and Reading, E. , 1976, Alaska's Volcanoes: Alaska Geographic, v. 4, no I., $88 \mathrm{p}$.

Herreid, G., 1966, The geology and geochemistry of the Inmachuk River map area, Seward Peninsula, Alaska: Fairbanks, Alaska Division of Mines and Minerals, Geologic Report no. 23, 25 P.

Hickel, W. J., 1972, Geothermal Energy, A national proposal for geothermal resources research: Final report of the Geothermal Resources Research Conf., Battelle Seattle Research Center, Sept. 18-20, 1971. Sponsored by NSF \& University of Alaska, Fairbanks, $95 \mathrm{p}$.

Higbie, R. G., 1975, The Katmal eruption and the Valley of Ten Thousand Smokes: National Geographic society Research Report, V. 8, p. 141-170.

Hildreth, W., 1980, Novarupta 1912: Petrology of the ejecta [abs.]: EOS, v. 61, no. 6, p. 66 .

Hildreth, W., 1981, The 1912 eruption in the Valley of Ten Thousand smokes, Ratmai National Monument, Alaska [abs.]: 
International Association of Volcanology and Chemistry of the Earth's Interior, Symposium on Arc Volcanism August 28September 9, 1981, Tokyo \& Hakone, Japan, p. 126-127.

Hildreth, w., 1983, The compositionally zoned eruption of 1912 in the valley of Ten Thousand Smokes, Katmal National Park, Alaska: Journal of Volcanology and Geothermal Research, v. 18 , p. 1-56.

Hildreth, W., and Flerstein, J. E., 1986, Near-vent ejecta around Novarupta, eruption on 1912, Katmal National Park, Alaska [abs.]: EOS, V. 67, no. 44, p. 1246.

Hildreth, W., Fierstein, J. E., Grunder, A. L., and Jager, L., 1981, The 1912 eruption in the Valley of Ten Thousand

smokes, Katmal National Park: A summary of the stratigraphy and petrology of the ejecta, in coonrad, W. L., and Elliott, R. E., eds., The U. S. Geological Survey in Alaska: Accomplishments during 1981: U. S. Geological survey Circular 868, p. 37-39.

Hildreth, W., and Grunder, A. L., 1980, The Valley of Ten Thousand Smokes tuff, II, compositional and isotopic variability of the ejecta [abs.]: Geological society of America, Abstracts with Programs, v. 12, p. 111.

Hoare, J. M., and Coonrad, W. L., 1959, Geology of the Russian Mission quadrangle, Alaska: U. S. Geological survey, Miscellaneous Geological Investigations Map I-292, I pl., scale $1: 250,000$.

Hobbs, P. V., Radke, I. F., and Stith, J. L. 1977, Eruptions of the St. Augustine Volcano: Airborne measurements and observations: Science, v. 195, no. 4281, p. 871-873.

Holmes, C. E., 1986, Archaelogical evaluation of the proposed Makushin geothermal power facility, Unalaska Island, Alaska, In Updike, R. G., ed., Engineering geology technical feasibility study, Makushin geothermal power project Unalaska, Alaska: Fairbanks, Alaska Division of Geological \& Geophysical Surveys, Public-data File 86-60, p. Il-I8, 1 pl, scale $1: 24,000$.

Homan, F., 1972, Energy from the Earth: Alaska Construction and O11 Report, Apri1 1972, p, 64-71.

Hopkins, D. M., 1963, Geology of the Imuruk Lake area, Seward Peninsula, Alaska: U. S. Geological Survey Bulletin 1141-C, $101 \mathrm{p}$.

Hopkins, J. P., and HopkIns, D. M., 1958, Seward Peninsula, in Howel, $W_{.}$, ed., Iandscapes of Alaska, their geologic evolution: Berkeley \& Ios Angeles, University of California Press, p. 104-110. 
Hopkins, D. M., and Taber, B., 1962, Stratigraphy of the preQuaternary bedded rocks of the Manley Hot Springs area, Alaska: Unpublished U. S. Geological Survey Bulletin, 131 p.

House, L., Sykes, L., Davies, J. N., and Jacob, K. H., 198I, Identification of a possible seismic gap near Unalaska Island, eastern Aleutians, Alaska, In simson, D. W., and Richards, P. G., eds., Earthquake prediction, an international Review: American Geophysical Union, Maurice Ewing Serles, v. 4, p. 81-92.

Hrdlicka, A., 1945, The Aleutian and Commander Islands and their inhabitants: wister Institute of Anatomy and Biology, Philadelphia, $630 \mathrm{p}$.

Hubbard, B. R., 1931, A world inside a mountain: National Geographic Magazine, v. 60 , no. 3, p. 319-354.

Hubbard, B. R., 1931, Geologic features of Aniakchak and Veniaminof craters, Alaska [abs.]: Journal of the washington Academy of Sciences, $v .21$, no. $2, p .29-30$.

Hubbard, B. R., 1935, Cradle of the storms: Ve11-Ballou Press, New York, $283 \mathrm{p}$.

Hudson, T. I., 1977, Genesis of a zoned granite stock, seward Peninsula, Alaska: U. S. Geological Survey Open-file Report $77-35,188 \mathrm{p}$.

Hudson, T. I., 1977, Genesis of a zoned granite stock, seward Peninsula, Alaska: stanford, California, stanford University, unpublished Ph.D. thesis, $190 \mathrm{p}$.

Hudson, T. I., compller, 1977, Geologic map of Seward Peninsula, Alaska: U. S. Geological survey Open-file Report 77-796-A, scale $1: 1,000,000$.

Hudson, T. I., 1979, Igneous and metamorphic rocks of the Serpentine Hot Springs area, Seward Peninsula, Alaska: U. S. Geological Survey Professional Paper 1079, $27 \mathrm{p}$.

Hudson, T. L., and Plafker, G. 1978, Kigluaik and Bendeleben faults, seward Peninsula: U. S. Geological survey Circular $772-B, 4 \mathrm{p}$.

Imm, T. A., 1986, Preliminary detailed stratigraphic sections and bedrock maps of the Iisburne group, Mt. Michelson C-3 and c-4 quadrangles, western Sadlerochit Mountains and northwest Shublik Mountains, northwestern Alaska: Fairbanks, Alaska Division of Geological and Geophysical surveys, public-data File $86-86 e, 34 \mathrm{p} ., 2$ pl., scale $1: 24,000$. 
Isselhardt, C. F., Matlick, J. S., Parmentier, P. P., and Bamford, R. W., 1983, Temperature gradient hole results from Makushin geothermal area, Unalaska Island, Alaska: Geothermal Resources Council Transactions, V. 7, p. 95-98.

Isselhardt, C. F., Motyka, R. J., Matlick, J. S., Parmentier, P. P., and Huttrer, G. W., 1983, Geothermal resource model for the Makushin geothermal area, Unalaska Island, Alaska: Geothermal Resources Council Transactions, v. 7, p. 99-104.

Jackson, S., 1880, Alaska, and missions on the north Pacific coast: Dodd, Mead, Co., New York, 327 p.

Jacob, K. H., and Boyd, T. M., 1985, Analysis of data from a temporary selsmic network on Unalaska Island: Alaska Division of Geological and Geophysical surveys, Public-data File $85-59,47 \mathrm{p}$.

Jaggar, T. A. Jr., 1908, Journal of the technology expedition to the Aleutian Islands, 1907: Technology Review, v. 10, p. 137.

Jaggar, T. A. Jr., 1908, The evolution of Bogoslof Volcano: Bulletin of the American Geographical Society, v. 40, p. 385-400.

Jaggar, T. A. Jr., 1927, Eruption of Mageik in Alaska: The Volcano Letter, Hawailan Volcano Observatory, no. 147.

Jaggar, T. A. Jr., 1908, The evolution of Bogoslof [abs.]: Science, v. 28, p. 575 .

Johnson, D. A., 1976, Evidence for a zoned magma chamber 6-10 km beneath Augustine Volcano, Alaska [abs.]: Geological Society of America, Abstracts with Programs, v. 8, p. 942943.

Johnson, D. A., 1978, Magma mixing prior to eruptions of Augustine Volcano, Alaska--implications for the eruption and magmatic evolution of the volcano [abs.]: Geological Soclety of America, Abstracts with Programs, 1978, p. 110111.

Johnson, D. A., 1978, volatiles, magma mixing, and the mechanism of eruption of Augustine Volcano, Alaska: Seattle, Washington, University of Washington, unpublished Ph.D. thesis, $177 \mathrm{p}$.

Johnson, D. A., 1979, Onset of volcanism at Augustine volcano, lower cook Inlet, in Johnson, K. M., and williams, J. A., eds., U. S. Geological Survey in Alaska: Accomplishments during 1978: U. S. Geological survey Circular 804-B, p. $\mathrm{B78}-\mathrm{B} 80$. 
Johnson, D. A., 1979, Volcanic gas studies at Alaskan volcanoes, In Johnson, R. H., and Williams, J. R., eds., U. S. Geological survey in Alaska: Accomplishments during 1978:

U. U. Geological survey Circular 804-B, p. B83-B84.

Johnson, D. A., 2980, Volcanic contribution of chlorine to the s. stratosphere - more significant to ozone than previously estimated: science, $v$. 209 , no. 4455, p. 491-493.

Johnson, D. A., and Detterman, R. I., 1979, Revision of the recent eruption history of Augustine - elimination of the "1902 eruption", In Johnson, K. M., and will lams, J. R., eds., U. S. Geological survey in Alaska: Accomplishments during 1978: U. S. Geologlcal survey Circular 804-B, p. B80B83.

Johnson, D. A., and Grunder, A. I., 1980, The Valley of ten Thousand Smokes Tuff: II. Compositional and isotopic variability of the ejecta [abs.]: Geological society of America, Abstracts with Programs, v. 12 , no. 3, p. 111.

Johnson, D. A., and Hildreth, W., 1980, The Valley of Ten Thousand smokes tuff, I: emplacement, compaction and welding [abs.]: Geological Society of America, Abstracts with Program, v. 12. p. 113.

Johnson, D. A., and Hildreth, W., 1980, The Valley of Ten Thousand smokes Tuff: I. Emplacement, compaction, and welding [abs.]: Geological soclety of America, Abstracts with Programs, v. 12, no. 3, p. 113.

Johnson, D. A., Schmincke, H. U., and Kienle, J., 1977, The eruption of Augustine Volcano, Alaska and evaluation of the hazards for furure eruptions [abs.]: Geologlcal society of America, Abstracts with Programs, v. 9, no. 4, p. 442-443.

Johnson, P. R., and Hartman, C. W., 1969, Environmental atlas of Alaska: Fairbanks, University of Alaska, Institute of Arctic Environmental Engineering, $111 \mathrm{p}$.

Jones, D., 1986, Coastal engineering, in Updike, R. G., ed., Engineering geology technical feasibility study, Makushin geothermal power project Unalaska, Alaska: Fairbanks, Alaska Division of Geological Geophysical surveys, Publicdata File 86-60, p. DI-D5.

Jones, D. I., silberling, N. J., Coney, P. J., and plafker, G., 2984, Lithostratographic terrane map of Alaska (west of the 14lst meridian), In Silbering, N. J., and Jones, D. I., eds. Iithotectonic terrane maps of the North American Cordillera: U. S. Geological survey Open-file Report 84523, p. Al-Al2, I pl., scale 1:5,000,000. 
Juhle, R. W., 1955, Illamna Volcano and lts basement: U. S. Geological survey Open-flle Report 55-77, $74 \mathrm{p}$.

Juhle, R. H. , and Coulter, H. W., 1955, The Mt. Spurr eruption, July 9, 1953: EOS, v. 36, no. 2, p. 199-202.

Kase, J. D., 1986, Trocadero Soda springs: Alaska Magazine, Feb. 1986, p. 30-31.

Katsul, Y., 1984, Okmok: Volcanologlcal soclety of Japan, Bulletin of volcanic eruptions, no. 22 .

KaY, S. M., and Kay, R. W., 1982, Maflc mineralogy in calcalkaline Aleutian volcanic rocks: Evidence for primitive magmas and magma mixing [abs.]: Geologlcal soclety of America, Abstracts with Programs, v. 14, no. 7. p. 526

KaY, S. M., Kay, R. W., and citron, G. P., 1982, Tectonic controls on tholeiftic and calc-alkaline magmatism in the Aleutian arc: Journal of Geophysical Research, $v$. 87, no. B5, p. 4051-4072.

Ke1th, T. E. C., 1984, Preliminary observations on fumarole distribution and alteration, valley of 10,000 Smokes, Alaska, In Reed, K. M., and Bartsch-Winkler, s., eds., U. S. Geological survey in Alaska: Accomplishments in 1982:

U. S. Geological survey Circular 939, p. 82-85.

Keith, T. E. C., 1985, Active hydrothermal alteration in the vicinity of the Novarupta dome, Valley of 10,000 smokes, Alaska [abs.]: EOS, v. 66, no. 46, p. 1154.

Keith, T. E. C., 1986, Distribution of hydrothermal alteration associated with Novarupta caldera, Katmai National Park, Alaska [abs.] : EOS, v. 67, no. 44, p. 1246.

Keith, T. E. C., and Foster, H. L., 1979, Big windy Creek hot springs, Circle A-1 quadrangle, Alaska, in Johnson, $K . M .$, and Williams, J. R., eds., U. S. Geological survey in Alaska: Accomplishments during 1978: U. S. Geological Survey Circular 804-B, p. B55-B57.

Ke1th, T. E. C., Presser, T. S., and Foster, H. I., 1981, New chemical and isotope data for the hot springs along Big Windy Creek, Circle A-I quadrangle, Alaska, in Albert, N. R. D., and Hudson, T. L., eds., U. S. Geological Survey in Alaska: Accomplishments during 1979: U. S. Geologlc Survey Circular 823-B, p. B25-B28.

Keller, A. S., 1955, General geology of the Katmal area, Alaska [abs.]: Geological Soclety of America Bulletin, $v .66$, no. 12, p. 1703 . 
Keller, A. S., and Reiser, H. N., 1959, Geology of the Mt. Katmal Area, Alaska: U. S. Geological Survey Bulletin 1058G, p. 261-298.

Kennedy, G. C., and Waldron, H. H., 1955, Geology of Pavlof Volcano and vicinity, Alaska: U. S. Geological survey Bulletin 1028-A, p. 1-18.

Kerr, F. A., 1948, Lower Stikine and western Iskut River areas, British Columbia, Canada: Canada Geologic Surveys Memoir $246,94 \mathrm{p}$.

Kienle, J., 1968, Gravity survey of Katmal National Monument: Fairbanks, University of Alaska, unpublished $\mathrm{Ph} . \mathrm{D}$. thesis, $151 \mathrm{p}$.

Kienle, J., 1969, Gravity traverses in the Valley of Ten Thousand Smokes, Katmal National Monument, Alaska [abs.]: EOS, v. 50 , no. 4, p. 340 .

Kienle, J., 1969, Gravity measurements in the Aleutian Archipelago and their interpretation [abs.]: EOS, v. 50, no. 4, p. 205.

Rienle, J., 1970, Gravity traverses in the Valley of Ten Thousand Smokes, Katmal National Monument, Alaska: Journal of Geophysical Research, v. 75, no. 32, p. 6641-6649.

Kienle, J., 1972, Volcanogenic micro-earthquakes of Augustine Volcano, Alaska [abs.]: EOS, v. 53, no. 11, p. 1044.

Kienle, J., 1974, Alaskan volcano studies with special reference to Augustine Volcano, in Colp, J. I., and Furumoto, A. F., eds., The utilization of volcano power: Proceedings of U. S. - Japan Cooperative science seminar, Hilo, Hawail, Feb. 4-8, 1974, p. 205-224.

Kienle, J., 1976, Selsmic monitoring of Pavlov Volcano, in Comprehensive study of seismotectonics of the Aleutian arc: Iamont-Doherty Geological observatory, Columbia University Annual Progress Report for ERDA under contract (11-1) 3134 , p. $38-40$.

Kienle, J., 1986, Augustine Volcano, southwest Alaska [abs.]: EOS, v. 67 , no. 44, p. 804 .

Kienle, J., Bingham, D. K., and Forbes, R. B., 1970, Seismic geologic evidence of pre-1912 tuff deposits in the valley of Ten Thousand Smokes, Katmai National Monument, Alaska [abs.]: EOS, V. 51, no. 11, p. 829.

Kienle, J., and Forbes, R. B., 1974, Alaskan volcano studies, with special reference to Augustine Volcano, in Colp, J. I., 
and others, eds., The utilization of volcano energy: Sandia National Laboratory, p. 205,223.

Klenle, J., and Forbes, R. B., 1977, Augustine - Evolution of a volcano: Fairbanks, University of Alaska, Geophysical Institute, Annual Report 1976, p. 26-49.

Kienle, J., Forbes, R. B., and Harlow, D. H., 1971, Recent microearthquake swarm activity at Augustine Volcano, Alaska [abs.]: EOS, v. 52, no. 11, p. 925.

Kienle, J., Kowalik, Z., and Murty, T. S., 1986, Tsunamis from large mass-movements at Augustine Volcano, cook Inlet, Alaska [abs.]: EOS, v. 67 , no. 44, p. 1259-1260.

Kienle, J., Kyle, P. R., Self, S., Motyka, R. J., and Lorenz, V., 1980, Ukinrek Maars, Alaska, I. Apr11 1977 eruption sequence, petrology and tectonic setting: Journal of Volcanology and Geothermal Research, v. 7, p. 11-37.

Kienle, J., Lalla, D. J., Pearson, C. F., and Barrett, S. A., 1979, Search for shallow magma accumulations at Augustine Volcano: Fairbanks, University of Alaska, Geophysical Institute, Final Report to U. S. Dept. of Energy, Washington, D. C., $157 \mathrm{p}$.

Kienle, J., and Lockhart, A. B., 1979, Selsmic and gravity surveys of Pligrim Springs Alaska [abs.]: Proceedings of 30th Alaska Science Conference, American Association for the Advancement of science, p. 59.

Rienle, J., and Lockhart, A. B., 2980, Gravity survey of the P1igrim Springs geothermal area, Alaska, in Turner, D. L., and Forbes, R. B., eds., Geological and Geophysical study of the geothermal potential of Pilgrim Springs, Alaska: Falrbanks, University of Alaska, Geophysical Institute Report, UAG-R-271, p. 73-80.

Kienle, J., Motyka, R. J., Lalla, D. J., Estes, S. A., and Huot, J. P., 1978, Formation of two maars behind the Aleutian volcanic arc, Alaska Peninsula, April 1977, preliminary results: fleld reconnaissance, geochemistry and seismicity: Fairbanks, University of Alaska, Geophysical Institute Report UAG-R-257, $26 \mathrm{p}$.

Kienle, J., and Pulpan, H., 1975, Tldally triggered microearthquake activity at Augustine Volcano, Alaska [abs.]: Proceedings International Union of Geodesy and Geophysics Interdisciplinary Symposium 14: Deep and shallow structures of volcanoes, Grenoble, France, Aug. 25 - Sept. 6, 1975, p. 206.

Klenle, J., Self, S., Motyka, R. J., and Huot, J. P., and Lalla, D. J., 1978, Formation of 2 maars behind the Aleutian 
volcantc arc in April 1977 [abs.]: Geological society of America, Abstracts with Programs, v. 10, p. 112.

Klenle, J., and Shaw, G. E., 1977, Augustine volcano eruption: Initial explosive phase, January 1976--impact on the atmosphere: Falrbanks, University of Alaska, Alaskan Earthquake Analysis Center Seismological Report no. 1, UAG$\mathrm{R}-249,48 \mathrm{p}$.

Ḱlenle, J., and Swanson, S.E., 1980, Volcanic hazards from future eruptions of Augustine Volcano, Alaska: Fairbanks, University of Alaska, Geophysical Institute Report UAG-R275,122 p.

Kienle, J., and Swanson, S. E., 1983, Volcanism in the eastern Aleutian arc: Iate Quaternary and Holocene centers, tectonic setting and petrology: Journal of Volcanology and Geothermal Research, v. 17, p. 393-432.

Klenle, J., and Swanson, S. E., 1983, Volcanism in the eastern Aleutian arc: Late Quaternary and Holocene centers, tectonic setting and petrology, In sheridan, M. F., and Barber1, F., eds., Explosive volcanism, developments in volcanology, v. 3: New York, Elsevier, p. 393-432.

Klenle, J., and Swanson, S. E., 1985, Volcanic hazards from future eruptions of Augustine Volcano, Alaska: Fairbanks, University of Alaska, Geophysical Institute Report UAG R275, Second Edition, 122 p.

Kienle, J., Swanson, E. E., and Pulpan, H., 1981, Volcanic centers in the Ratmal area, Alaska [abs.]: EOS, v. 62, p. 430 .

Kienle, J., Swanson, S. E., and Pulpan, H., 1981, Subduction and magmatism in the eastern Aleutian arc [abs.]: International Association of Volcanology and Chemistry of the Earth's Interior, Symposium on ArC Volcanism, August 28-September 9, 1981, Tokyo Hakone, Japan, p. 177-i78.

Kienle, J., Swanson, S. E., and Pulpan, H., 2983, Magmatism and subduction in the eastern Aleutian arc, in Shimozuru, D., and Yokoyama, I., eds., Arc volcanism: Physics and tectonics: Tokyo, Japan, Terra Scientiflc Publishing co., p. 191-224.

King, J., 1909, The Tanana valley: Alaska Yukon Magazine, v. 7, no. 5, p. $251-258$.

Kline, J. T., 1980, Test drilling report--procedures and results of two test holes drilled at Pilgrim springs, Alaska in October and November, 1979: Fairbanks, Alaska Division of Geological and Geophysical surveys Report to Alaska Division of Energy and Power Development, $6 \mathrm{p}$. 


\section{4titit}

KIIne, J. T., 1981, Surficial geology of lower Pilgrim Valley and vicinity, western Seward Peninsula, Alaska: Fairbanks, Alaska Division of Geological and Geophysical Surveys Openfile Report AOF 140, 2 pl., scale 1:24,000.

Rline, J. T., Reger, R. D., McFarlane, R. M., and Williams, T., 1980, Surficial geology and test drilling at Pilgrim Springs, Alaska, in Turner, D. L., and Forbes, R. B., eds., Geological \& geophysical study of the geothermal potential of Pilgrim Springs, Alaska: Fairbanks, University of Alaska, Geophysical Institute Report, UAG-R-271, p. 21-28.

Knappen, R. S., 1926, Geology and mineral resources of the Anlakchak district: U. S. Geological Survey Bulletin 797, p. 161-223.

Knappen, R. S.; 1933, Anlakchak and Veniaminof volcanoes, Alaska [abs.]: Geological Soclety of America Bulletin, v. 44, no. I. p. $90-91$.

Knopf, A., 1912, The sitka mining district, Alaska: U. $S$. Geological Survey Bulletin $504,32 \mathrm{p}$.

Kodosky, L. G., and Keskinen, M., 1986, Preliminary observations on fumarole distribution and alteration at Augustine Volcano, Alaska [abs.]: EOS, v. 67, no. 44, p. 1260.

Kosco, D. G., 1981, Characteristics of andesitic to dacitic volcanism at Katmal National Park, Alaska [abs.]: Geological Society of America, Abstracts with Programs, v. 13 , p. 490 .

Kosco, D. G., 1981, Part I: The Edgecumbe volcanic field, Alaska: an example of tholeiltic and calc-alkaline volcanism; Part II: Characteristics of andesitic to dacitic volcanism at Ratmal National Park, Alaska: Berkeley, California, University of California, unpublished $\mathrm{Ph} . \mathrm{D}$. thesis, $249 \mathrm{p}$.

Rrause, K., 1986, Transmission powerline and road corridor geotechnical study for the proposed Makushin geothermal fleld power facility on Unalaska Island, in Updike, R. G., ed., Engineering geology technical feasibility study, Makushin geothermal power project Unalaska, Alaska: Fairbanks, Alaska Division of Geological \& Geophysical Surveys, Public-data file 86-60, p Cl-C17, 1 pl, scale $1: 24,000$.

Kubota, S., and Berg, E, 1967, Evidence for magma in the Katmai volcanic range: Bulletin of Volcanology, v. 31, p. 175-214.

Kunza, J. F., and Lofgren, B. E., 1983, Pilgrim Springs, Alaska geothermal resource exploration, drililng and testing: 
Geothermal Resources Council, Transactions, v. 7, p. 301304.

Lachenbruch, A. H., Sass, J. H., Marshall, B. V., Moses, T. H. Jr., Munroe, R. J., and Smith, E. P., 1984, Geothermal studies in Alaska: Conditions at Prudhoe Bay, in Coonrad, W. L., and Elllott, R. L., eds., U. S. Geological survey in Alaska: Accomplishments during 1981: U. S. Geological Survey Circular 868, p. 19-20.

Lalla, D. J., 1987, Seismologic and thermal studies at Augustine Volcano: Fairbanks, Univertsity of Alaska, Ph.D. Thesis (in preparation).

Lalla, D. J., and Kienle, J., 1974, Infrared radiation thermometry of Augustine Volcano, Alaska [abs.]: EOS, v. 56, no. 12 , p. 1199.

Lalla, D. J., and Rienle, J., 1975, Micro earthquake activity and volcanic tremor associated with strombolian eruptions of Pavlov Volcano, Alaska [abs.]: Proceedings International Union of Geodesy and Geophysics Interdisciplinary Symposium 14: Deep and shallow structures of volcanoes, Grenoble, France, Aug. 25 - Sept. 5, 1975, p. 107.

Lalla, D. J., and Kienle, J., 1976, Thermal studies on Augustine Volcano, Alaska [abs.]: Eos, v. 57, no. 4, p. 347.

Lalla, D. J., and Kienle, J., 1978, Evolution of seismicity at Augustine volcano, 1970-1976 eruption [abs.]: Geological Society of America, Abstracts with Programs 1978, v. 10, no. 3, p. 113 .

Lalla, D. J., and Kienle, J., 1980, Problems in volcanic seismology on Augustine Volcano,.. Alaska [abs.]: EOS, v. 61, no. $6, \mathrm{p} .68$.

Lalla, D. J., and Kienle, J., 1986, Selsmic and thermal precursors to the January, 1976 eruption of Augustine Volcano, Alaska: International volcanological Congress, Auckland-Hamilton-Rotorua, New zealand, Programme and Abstracts, in press.

Lankford, S. M., and Hill, J. M., 1979, Stratigraphy and depositional environment of the Dutch Harbor member of the Unalaska formation, Unalaska Island, Alaska: U. S. Geological Survey Bulletin 1457-B, p. B1-B14.

Lawton, N. O., 1909, Makushin sulfur deposits, Unalaska: Mining \& Science Press, v. 98, p. 259-260.

Lawver, I. A., Lachenbruch, A. H., and Moses, T. H. Jr., 1979, Status of regional heat-flow studies in Alaska, in Johnson, K. M., and williams, J. R., eds., U. s. Geological survey in 
Alaska: Accomplishments during 1978: U. S. Geological Survey Circular 804-B, p. B5-B7.

Lecompte, J. R., 1981, Preliminary maps showing interpretation of Landsat imagery of the Ugashik and Karluk quadrangles, Alaska: U. S. Geological Survey Open-file Report 81-776, 2 pl., scale 1:250,000.

Lecompte, J. R., and Steele, W. C., 1981, Maps showing interpretation of Landsat imagery of the Chignik and sutwik Island quadrangles, Alaska: U. S. Geological survey Miscellaneous Field Studies Map MF-1053-0, 2 pl., scale $1: 250,000$.

Leonard, L. E., 1975, What's old in geothermal energy: Northern Engineer, v. 6, no. 4, p. 3-7.

Lew1s, R. Q., Nelson, W. H., and Powers, H. A., 1960, Geology of Rat Islands, Aleutian Islands, Alaska: U. S. Geological survey Bulletin $1028-Q$, p. 533-562.

Limke, A. J,, and Beget, J. E., 1986, Emplacement velocities and rheological properties of pyroclastic flows during the March 27-April 8 eruption of Mt. St. Augustine, Alaska [abs.]: EOS, v. 67 , no. 44 , p. 1259.

Lockhart, A. B., 1981, Gravity survey of the central seward Peninsula, in Wescott, E. M., and Turner, D. L., eds., Geothermal reconnalssance survey of the central seward Peninsula, Alaska: Fairbanks, University of Alaska, Geophysical Institute Report, UAG-R-284, p. 61-72.

Lockhart, A. B., and Kienle, J., 1980, Selsmic refraction and gravity surveys of P1lgrim Springs KGRA, Alaska: Geothermal Resources Council, Transactions, v. 4, p. 213-216.

Lofgren, B., ed., 1983, Geothermal energy development at Pilgrim Springs, Alaska: Woodward clyde, consultants, report to Alaska Division of Energy and Power Development, $62 \mathrm{p}$.

Loney, R. A., Berg, H. C., Pomeroy, J. S., and Brew, D. A., 1963, Reconnaissance geologic map of Chichagof Island and northwestern Baranof Island, Alaska: U. S. Geological Survey Miscellaneous Geologic Investigations, Map I-388, scale $1: 250,000$.

Loney, R. A., Brew, D. A., Muffler, L. J. P., and Pomeroy, J. S. 1975, Reconnaissance geology of Chichagof, Baranof and Kruz of Islands, southeastern Alaska: U. S. Geological Survey Professional Paper no. 792, 105 p.

Loney, R. A., Brew, D. A., and Lanphere, M. A., 1967, PostPaleozolc radiometric ages and their relevance to fault 
movements, northern southeastern Alaska: Geological Society of America Bulletin, v. 78, p. 511-526.

Loney, R. A., Condon, w. H., and Dutro, J. T. Jr., 1963, Geology of the Freshwater Bay Area, Chichagof Island, Alaska: U. S. Geological survey Bulletin 1108-C, p. Cl-C54.

Loney, R. A., Pomeroy, J. S., Brew, D. A., and Muffler, I. J. P. , 1964, Reconnaissance geologic map of Baranof and Kruzof Islands, Alaska: U. S. Geological Survey, Miscellaneous Geologic Investigations Map, I-411, scale 1:250,000.

Long, W. E., 1986, Glacial hazard constraints, in Updike, R. G., ed., Engineering geology technical feasibility study, Makushin geothermal power profect Unalaska, Alaska: Fairbanks, Alaska Division of Geological \& Geophysical surveys, Public-data File 86-60, P. Fl-F15, I pl., scale $1: 24,000$.

Longenkamp, D., Nelson, J. S., and England, J. M., 1974, Electrical resistivity survey for geothermal resources, Pilgrim Springs, Alaska: Harding-Lawson Associates report to Stefano and Associates, Anchorage, Ak.

Iorenz, V., 1982, The 1977 explosive eruption of the Ukinrek Maars, Alaska: Terra Cognita, v. 2, p. 205-206.

Lovering, T. S., 1955, Alteration near an acid halogen-sulfur fumarole [abs.]: Geological Society of America Bulletin, v., 66, no. 12 , p. 1590 .

Lovering, T. S., 1957, Halogen-acid alteration of ash at Fumarole no. 1, Valley of Ten Thousand Smokes, Alaska: Geological Society of America Bulletin, v. 68, p. 1585-1604.

Lyle, w. M., 1973, Geology and mineral evaluation of the Aniakchak River drainage, Alaska Peninsula: Fairbanks, Alaska Division of Geological and Geophysical Surveys Openfile Report 26, $11 \mathrm{p}$.

Lyle, W. M., and Dobey, P. I., 1974, Geologic evaluation of the Herendeen Bay area, Alaska Peninsula: Fairbanks, Alaska Division of Geological and Geophysical surveys open-file Report 48,20 p., 3 pl., scale 1:63,360.

MacGregor, A. G., 1952, Eruptive mechanisms--Mt. Pelee, the Soufriere of st. Vincent (West Indies) and the Valley of Ten Thousand Smokes (Alaska): Bulletin Volcanologique, v. 12, p. 49-74, with discussion p. 5-6.

MacKevett, E. M. Jr., 1976, Geologic map of the Mc Carthy guadrangle, Alaska: U: S. Geological Survey Miscellaneous Field studies Map MF-773 A, scale 1:250,000. 
Mackevett; E. M. Jr., 1978, Geologic map of the Mc Carthy quadrangle, Alaska: U. S. Geologlcal Survey Miscellaneous Geologic Investigations Map I-1032, scale 1:250,000.

Maddren, A. G., 1919, Sulphur on Unalaska and Akun Islands and near stepovak Bay, Alaska: U. S. Geological Survey Bulletin 692-E, p. 283-298.

March, G. D., 1986, Avalanche hazard constraints, in Updike, R. G., ed., Engineering geology technical feasibility study, Makushin geothermal power project Unalaska, Alaska: Falrbanks, Alaska Division of Geological Geophysical Surveys, Public-data File 86-60, p. GI-G8, 2 pl., scale $1: 24,000$.

Mariner, R. H., Brook, C. A., Swanson, J. R,, and Mabey, D. R., 1978, Selected data for hydrothermal convection systems in the United states with estimated temperatures $>=90$ deg. C.: U. S. Geological Survey Open-f1le Report 78-858.

Markle, D. R., 1979, Geothermal energy In Alaska: site data base and development status: Anchorage, Alaska Division of Mineral \& Energy Management report to $U$. $s$. Dept. of Energy under contract DE-ACO3-79SF1049, 2 vols, 545 p.

Markle, D. R., 1979, Prospects for geothermal energy development at Pilgrim Springs, Alaska [abs.]: Proceedings 30th Alaska Sclence Conference, American Assoclation for the Advancement of science, p. 62 .

Marsh, B. D., 1974, Aleutian Lsland arc magmatism: Berkley, California, University of California, unpublished Ph.D. thesis.

Marsh, B. D., 1980, Geology and petrology of northern Atka, Aleutian Islands, Alaska [abs.]: Geological society of America, Abstracts with Programs, v. 22 , p. 476 .

Marsh, B. D., 1982 , The Aleutians, in Thorpe, R. S., ed., orogenic andesites and related rocks: New York, John wiley \& Sons, p. 99-113.

Martin, G. C., 1913, The recent eruption of Katmal volcano in Alaska: National Geographic Magazine, v. 24, p. 131-181.

Martin, G. C., 1917, Mineral resources of Alaska: U. S. Geological survey Bulletin 692, $400 \mathrm{p}$.

Martin, G. C., and Katz, F. J., 1910, Outline of the geology and mineral resources of the Iliamna and Clark Lakes region: U. S. Geological Survey Bulletin 442, p. 179-200. 
Martin, G. C., and Katz, F..J., 1912, A geologic reconnalssance of the Iliamna region, Alaska: U. S. Geological Survey Bulletin 485, 138 p.

Matlick, J. S., and Parmentier, P. P., 1983, Geothermal mainfestations and results of a mercury soil survey in the Makushin geothermal area, Unalaska Island, Alaska: Geothermal Resources Council Transactions, v. 7, p. 305-309.

Matumoto, T., 1971, Seismic body waves observed in the vicinity of Mt. Katma1, Alaska, and evidence for the existence of molten chambers [abs.]: Geological society of America Bulletin, v. 82, p. 2905-2920.

Matumoto, T., and Molnar, P., 1967, A shadow effect on $S$ waves observed in the vicinity of Mount Katmai, Alaska [abs.]: EOS, v. 48, p. 199.

Matumoto, T., and Ward, P. L., 1967, Microearthquake study of Mt. Ratmai and vicinity, Alaska: Journal of Geophysical Research, v. 72, p. 2557-2568.

Mauk, F. J., and Kienle, J., 1973, Microearthquakes at st. Augustine Volcano, Alaska, triggered by earthtides: Science, v. 182 , no. 4110 , p. 386-389.

McNutt, S. R., 1983, Seismic and eruptive activity of Pavlov Volcano, 1973-1983, related to Shumagin seismic gap? [abs.]: EOS, v. 64, no. 18 , p. 258 .

McNutt, S. R., 1984, Eruption cycles and characteristics, and the state of stress at Pavlov volcano, eastern Aleutians [abs.]: EOS v. 65, no. 15, p. 242.

McNutt, S. R., and Beavan, R. J., 1981, Volcanic earthquakes at Pavlov Volcano correlated with the solid earth tide: Nature, v. 294, p. 615-618.

McNutt, S. R., and Beavan, R. J., 1984, Periodic eruptions of Pavlov Volcano, Alaska: The effects of sea level and an aselsmic slip event [abs.]: EOS, v. 65, no. 45, p. 1149.

McNutt, S. R., and Mor1, J., 1983, Analysis of B-type earthquakes and explosions at Pavlov Volcano, Alaska [abs.]: EOS, v. 64 , no. 5 , p. 45 .

Meaker, P., 1908, The Tanana Valley of Alaska: Alaska Yukon Magazine, v. 4, no. 6, p. 437-449.

Meigs, A. J., 1986, Structural evolution of the eastern Sadlerochit Mountains, northeastern Brooks Range, Alaska: A preliminary report based on summer 1986 field season: Fairbanks, Alaska Division of Geological and Geophysical 
Surveys, Public-data File 86-86f, 6 p., l pl., scale $1: 25,000$.

Mendenhall, w. C., 1903, The mineral resources of the Mount Wrangell district, Alaska: U. S. Geological survey Professional paper no. 15, p. 1-71.

Mendenhal1, W. C., 1905, Geology of the central Copper River region, Alaska: U. S. Geological Survey Professional Paper no..41, $133 \mathrm{p}$.

Menyaylov, I. V., 1969, Fumarolnyye gazy piroklasticheskikh potokov vulkonov Bezymyannogo 1 Katmal: vulkany 1 izverzheniya, Moscow, Izdatelstvo Nauka, p. 78-81.

Menzie, W. D., Foster, H. L., Tripp, R. B., and Yeend, W. E., 1983, Mineral resource assessment of the Circle quadrangle, Alaska: U. S. Geological survey Open-file Report 83-170B, 61 p., 1 pl. scale 1:250,000.

Merriam, C. H., 1901, The birth of an American volcano, Bogoslof in Bering Sea: Everybodys Magazine, v. 5, p. 293-301.

Merrill, G. P., 1885, on hornblende andesites from the new volcano on Bogosioff Island in Bering Sea: Proceedings of United States National Museum, v. 8, no. 3, p. 31-33.

Merriman, C. H., 1910, Bogoslof, our newest volcano: Smithsonian Institute, Harriman Alaska Series, v. 2, p. 291336 .

Mertie, J. B. Jr., 1930, Geology of the Eagle-circle District, Alaska: U. S. Geologlcal survey Bulletin 816, 167 p.

Mertie, J. B. Jr., 1932, The Yukon-Tanana region, Alaska: U. $S$. Geologlcal survey Bulletin $872,276 \mathrm{p}$.

Mertle, J. B. Jr., 1934, Mineral deposits of the Rampart and Hot Springs districts: $U$. S. Geological survey Bulletin 844-D, p. $163-246$.

Metzner, R. C., 1975, A magnetoteliuric investigation of Augustine Island Volcano: Falrbanks, University of Alaska, unpublished M. S. thesis, $116 \mathrm{p}$.

Miller, T. P., 1970, Petrology of the plutonic rocks of westcentral Alaska: U. S. Geological survey Open-file Report $454,76 \mathrm{p}$.

Miller, T. P., 1971, Petrology of the plutonic rocks of westcentral Alaska: Stanford, California, stanford University, unpublished Ph.D. thesis, $78 \mathrm{p}$. 
Miller, T. P., 1972, Potassium-rich alkaline intrusive rocks of western Alaska: Geological Society of America Bulletin, v. 83, p. 2111-2128.

Miller, T. P., compiler, 1973, Distribution and chemical analyses of thermal springs in Alaska: U. S. Geological survey Open-file Map 570, scale 1:2,500,000.

Miller, T. P., 1976, Augustine Volcano: Alaska's Volcanoes, northern ilink of the ring of fire, Alaska Geographic, v. 4, no. 1 , p. 17-28.

Miller, T. P., 1978, Post-caldera airfall pumice at Aniakchak caldera: U. S. Geological Survey Professional Paper 1109, p. 84 .

Miller, T. P., 1984, Two-stage volcanism at the Ugashik-Peulik volcanic center, Alaska Peninsula [abs.]: Geological Society of America, Abstracts with Programs, v. 16, no. 5, p. 322 .

Miller, T. P., and Barnes, Ivan, 1974, Potential for geothermal energy development in Alaska [abs.]: American Association of Petroleum Geologists Bulletin, v. 58, no. 7, p. 1450.

Miller, T. P., and Barnes, Ivan, 1976, Potential for geothermal energy development in Alaska - summary: Circum-Pacific energy and mineral resources, American Association of Petroleum Geologist Memoir no. 25, p. 149-153.

Miller, T. P., Barnes, Ivan, and Patton, W. W. Jr., 1975, Geologic setting and chemical characteristics of hot springs in west-central Alaska: Journal of Research, 0 . $s$. Geological survey, v. 3, no. 2, p. 149-162.

Miller, T. P., Grybeck, D. G., Elliott, R. L., and Hudson, T. L., 1972, Preliminary geologic map of the eastern Solomon and southeastern Bendeleben quadrangles, eastern Seward Peninsula, Alaska: 0 . S. Geological survey Open-file Report 537, 11 p., 1 pl., scale 1:250,000.

Miller, T. P., Patton, w. W. Jr., and Lanphere, M. A., 1966, Preliminary report on a plutonic belt in west-central

Alaska: U. S. Geological Survey Professional Paper 550-D, p. D158-D162.

Miller, T. P., and Smith, R. L., 1975, Ash flows on the Alaska Peninsula: a preliminary report on their distribution, composition, and age [abs.]: Geological society of America, Abstracts with Programs, v. 7, p. 1201.

Miller, T. P., and Smith, R. L., 1975, Alaska geothermal study, in Yount, M. E., ed., The U. S. Geological Survey Alaska Program, 1975: U. S. Geological Survey Circular 722, p. 39. 
M1ller, T. P., and Smith, R. I., 1976, "New" volcanoes in the Aleutian volcanic arc, in Cobb, E. H., ed. U. S. Geological Survey in Alaska: Accomplishments during 1975: U. S. Geological survey circular 773, p. 11.

Milier, T. P., and Smith, R. I., 1976, Ash flows associated with Wrangell Volcano, in Cobb, E. H., ed., U. S. Geological Survey in Alaska: Accomplishments during 1975: U. S. Geological Survey Circular 733, p. 52 .

M1ller, T. P., and Smith, R. I., 1976, Two caldera forming eruptions on Umnak Island, eastern Aleutian Islands, in Cobb, E. H., ed., U. S. Geologlcal Survey in Alaska: Accomplishments during 1975: U. S. Geologlcal Survey Circular 733, p. 45.

Miller, T. P., and Smith, R. I., 1977, Spectacular mobility of ash flows around Aniakchak and Fisher calderas, Alaska: Geology, v. 5, p. 173-176.

Miller, T. P., and Smith, R. I., 1983, Calderas of the eastern Aleutian arc [abs.]: EOS, v. 64, no. 45, p. 877 .

Moffit, F. H., 1905, The Fairhaven gold placers, seward Peninsula, Alaska: U. S. Geological Survey Bulletin 247, 85 p.

Monger, J. W. H., and Berg, H. C., 1985, Ithostratographic terrane map western Canada and southeastern Alaska, in S1Iberling, N. J., and Jones, D. L., eds., Ilthotectonic terrane maps of the North American Cordiliera: $U$. $S$. Geological Survey Open-file Report 84-523, p. B1-B12, I pl., scale $1: 5,000,000$.

Morgan, I., ed., 1980, The Aleutlans: Alaska Geolgraphic, v. 7, no. $3,224 \mathrm{p}$.

Morr1s, D., 1985, Ratmal National Park and Preserve, Draft general management plan: $U$. $s$. Department of the Interior, National Park Service, $158 \mathrm{p}$.

Morrison-Rnuason Co., Inc., 1981, Geothermal potentlal in the Aleutlans: Unalaska: Report for Alaska Division of Energy and Power Development, $p .2-5$.

Motyka, R. J., 1977, Katmal Caldera: Glaclers growth, lake rise, and geothermal activity, in short Notes on Alaskan Geology, 1977: Falrbanks, Alaska Division of Geological and Geophysical Surveys Report No. 55, p. 17-22.

Motyka, R. J., 1978, Survelliance of Katmal Caldera and Crater Lake, Alaska, 1977: Fairbanks, University of Alaska, 
Geophysical Institute report to U. S. Park service P. 0 . PX9100-7-1009, 19 p.

Motyka, R. J., 1982, Thermal fluid geochemistry of the Makushin and Akutan geothermal prospects, in Geothermal direct heat program roundup technical conference proceedings, $v$. 1: Earth Science Iaboratory, University of Utah Research Institute Publication ESI-98, Salt Lake City, p. 8-32.

Motyka, R. J., 1982, Fluid geochemistry of the Makushin geothermal area, Unalaska Island, Alaska: Geothermal Resources Council Transactions, v. 6, p. 107-110.

Motyka, R. J., 1982, High temperature hydrothermal resources in the Aleutian Arc [abs.]: Alaska Geological society Symposium, 1982, Program with Abstracts, p. 41-42.

Motyka, R. J., 1983, High-temperature hydrothermal resources in the Aleutian arc: Proceedings of Alaska Geological society Symposium on western Alaska geology and resource potential, Journal of Alaska Geological Society, v. 3, p. 87-99.

Motyka, R. J., 1983, Geochemical and 1sotopic studies of waters and gases from the Makushin geothermal area, Unalaska Island, Alaska: Geothermal Resources Council Transactions, v. T, p. 103-108.

Motyka, R. J., 1983, Increases and fluctuations in thermal activity at Mount Wrangell, Alaska: Fairbanks, University of Alaska, unpublished Ph.D. thesis, $349 \mathrm{p}$.

Motyka, R. J., 1984, Chemlstry of thermal waters and fumarole gases from North Crater, Mt. Wrangell, Alaska [abs.]: Geological Society of America, Abstracts with Programs, v. 16 , no. 5 , p. 323 .

Motyka, R. J., and Benson, C. S., 1982, Cyclic heat fluctuations in heat flow from the North Crater, Mt. Wrangell, Alaska [abs.]: Proceedings Northwest meeting of American Geophysical Union, Sept. 15-16, 1982 .

Motyka, R. J., Ferrell, V. M., and Benson, C. S., 1977 , Glaclological-volcanological investigations in Katmal National Monument [abs.]: in Scott, S. A., ed., 4 th Annual National Park Service Pacific Northwest Region science Management Conference, p. 22.

Motyka, R. J., Forbes, R. B., and Moorman, M. A., 1980, Geochemistry of Pilgrim springs thermal waters, in Turner, D. I., and Forbes, R. B., eds., Geological and geophysical study of the geothermal potential of Pilgrim Springs, Alaska: Fairbanks, University of Alaska, Geophysical Institute Report, UAG-R-271, p. 43-52. 
Motyka, R. J., Hawkins, D. B., Poreda, R. J., and Jeffries, A., 1986, Geochemistry, isotopic composition, and the origin of flulds emanating from mud volcanoes in the Copper River basin, Alaska: Fálíbanks, Alaska Divilsion of Geological and Geophysical Surveys, Public-data File 86-34, 87. p.

Motyka, R. J., Kodosky, I. G., and Evans, W., 1986, A review of gas sampling at Augustine Volcano, Alaska: 1982-1986 [abs.]: EOS, v. 67, no. 44, p. 1260.

Motyka, R. J., Mackeith, P., and Benson, c. S., 1978, Increased heating and geothermal heat flow at Mt. Wrangell Caldera, Alaska [abs.]: EOS, v. 59, no. 12, p. 1201.

Motyka, R. J., Mackeith, P, and Benson, c. S., 1980, Mt. Wrangell caldera: Utilization of glacier ice to measure heat flow and infer thermal regime [abs.]: EOS, $v .61$, no. 6, p. 69 .

Motyka, R. J., and Moorman, M. A., 1980, Assessment of thermal spring sites in southern southeastern Alaska--Preliminary results and evaluation [abs.]: Proceedings of 31 th Alaska Sclence Conference, Anchorage, Ak., American Association for the Advancement of Science, p: 135.

Motyka, R. J., and Moorman, M. A., 1981, Reconnaissance of thermal spring sites in the Aleutian Arc, Atka Island to Becharof Lake: Geothermal Resources Council Transactions, v. 5, P. 111-114.

Motyka, R. J., and Moorman, M. A., 1987, Geothermal resources of southeast Alaska: Fairbanks, Alaska Division of Geological and Geophysical surveys, Professional Report (in press).

Motyka, R. J., Moorman, M. A., and Liss, S. A., 1981, Assessment of thermal spring sites, Aleutian arc, Atka Island to Becharof Lake--preliminary results and evaluation: Fairbanks, Alaska Division of Geological and Geophysical Surveys Open-f11e Report $144,173 \mathrm{p}$.

Motyka, R. J., Moorman, M. A., and ILss, S. A., 1983, Geothermal resources of Alaska: Geophysical Data Center, National Oceanic and Atmospheric Administration, 1 pl., scale $1: 2,500,000$.

Motyka, R. J., Moorman, M. A., and Poreda, R. J., 1982, Fluid geochemistry of the Makushin geothermal area, Unalaska Island, Alaska: Geothermal Resources Council Transactions, v. 6, p. 107-110.

Motyka, R. J., Moorman, M. A., and Poreda, R. J., 1982, Fluid geochemistry of Hot Springs Bay Valley, Akutan Island, Alaska: Geothermal Resources Council Transactions, v. $6, p$. 103-106. 
Motyka, R. J., Moorman, M. A., and Poreda, R. J., 1983, Progress report - thermal fiuid investigations of the Makushin geothermal area: Fairbanks, Alaska Division of Geological and Geophysical Surveys Report of Investigations 83-15, 48 p.

Motyka, R. J., Moorman, M. A., and Reeder, J. W., 1980, Assessment of thermal spring sites in southern southeastern Alaska - Preliminary results and evaluation: Fairbanks, Alaska Division of Geological and Geophysical surveys openfile Report $127,72 \mathrm{p}$.

Motyka, R. J., and Queen, I. D., 1984, 1983 and 1984 Alaska Division of Geological and Geophysical Surveys geothermal fluids sampling and well logging at the Makushin geothermal area:: Fairbanks, Alaska Division of Geological and Geophysical Surveys, Public-data File 84-51, 50 p.

Motyka, R. J., Queen, I. D., Janik, C. J., Sheppard, D. S., Poreda, R. J., and Iiss, S. A., 1986, Fluld geochemistry and fluid mineral equilibria in test welis and thermal gradient holes at the Makushin Geothermal area, Unalaska Island, Alaska: Fairbanks, Alaska Division of Geological and Geophysical Surveys, Public-data File 86-59, 155 p.

Motyka, R. J., Wescott, E. M., Turner, D. L., Swanson, S. E., Romick, J. D., Moorman, M. A., Poreda, R. J., Witte, W., Petzinger, B., Allely, R. D., 1985, A geological, geochemical and geophysical survey of the geothermal resources at Hot Springs Bay Valley, Akutan Island, Alaska: Falrbanks, Alaska Division of Geological and Geophysical Surveys report to U. S. Department of Energy, 167 p., 2 pl., scale $1: 20,000$.

Muffler, I. J. P., 1973, Geothermal resources, in Brobst, D. A., and Pratt, W. P., eds., United states Mineral Resources: U. S. Geological survey Professional paper 820, p. 251-261.

Muffler, I. J. P., 1979, Assessment of geothermal resources of the United States--1978: U. S. Geological survey Circular 790, 163 p.

Muller, E. H., Juhle, R. W., and coulter, H. W., 1954, Current volcanic activity in Katmai National Monument: Science, $v$. 119 , p. 319-321.

Myers, J. D., 1978, Petrography and petrogenesis of the Edgecumbe volcanic field, Kruzof Island, SE Alaska [abs.]: Geological society of America, Abstracts with Programs, $v$. 10 , no. 7, p. 461 .

Myers, J. D., 1979, Geology and petrology of the Edgecumbe volcanic fleld, southeastern Alaska: Transform fault 
volcanism and magma mixing: Baltimore, Maryland, John Hopkins University, unpublished Ph.D. thesis, $306 \mathrm{p}$.

Myers, J. D., and Marsh, B. D., 1981, Geology and petrogenesis of the Edgecumbe volcanic field, southeastern Alaska: The interaction of basalt and sialic crust: Contributions to Mineralogy and Petrology, v. 77, p. 272-287.

Myers, J. D., Marsh, B. D., and Sinha, A. K., 1986, Strontium isotopic and selected trace element variations between two Aleutian volcanic centers (Adak and Atka): Implications for the development of arc volcanic plumbing systems: Journal of Geology (in press)

Myers, J. D., Sinha, A. K., and Marsh, B. D., 1984, Assimilation of crustal material by basaltic magma: Strontium 1sotopic and trace element data from the Edgecumbe volcanic fleld, southeast Alaska: Journal of Petrology, v. 25, pt. 1, p. 126.

Nakamura, K., Jacob, K. H., and Davies, J. N., 1977, Volcanoes as possible indicators of tectonic stress orientation Aleutians and Alaska: Pure and Applied Geophysics, v. 115, p. 87-112.

Nathenson, M., Guffant1, M., Sass, J. H., and Monroe, R. M., 1983, Regional heat flow and temperature gradients, in Reed, M. J., ed., Assessment of low-temperature geothermal resources of the United States-1982: U. S. Geological Survey Circular 892, 73 p.

Nava, J. A., 1975, A note on hot springs in southeastern Alaska: Arctic, v. 28, no. 2, p. 143-144.

Nava, J. A., and Morrison, P., 1974, A note on hot springs in the interior of Alaska: Arctic, Sept. 1974, p. 241-243.

Neal, R. J., and Swanson, S. E., 1983, Petrology - Geochemistry of Westdahl and Pogromnl Volcanoes, Unimak Island, Alaska [abs.]: EOS, v. 64, no. 45, p. 893.

Nehring, N. I., Mariner, R. H., White, L. D., Huebner, M. A.: Roberts, E. D., Harmon, K., Bowen, P. A., and Tanner, L., 1979, Sulfate geothermometry of thermal waters in the western United States: U. S. Geological Survey Open-file Report 79-1135, 11 p.

Nelson, S. W., and Grybeck, D. G., 1978, The Arrigetch Peaks and Mt. Igikpak plutons, Survey Pass quadrangels, Alaska, in Johnson, K. M., ed., U. S. Geological Survey in Alaska: Accomplishments during 1977: U. S. Geological survey Circular 772-B, p. B7-B9. 
Nelson, W. H., 1959, Geology of Segula, Davidof and Khvostof Islands, Alaska: U. S. Geological survey Bulletin 1028-F, p. 257-266.

Nichols, C. R., and Reeder, J. W., 1983, Alaska geothermal resource characteristics and their implication for large and small scale hydrothermal development: Proceedings 4 th Alaska Alternative Energy Converence, Anchorage, 1983, p. 100-102.

Nichols, D. R., and Yehle, L. A., 1961, Analyses of gas and water from two mineral springs: the Copper River basin, Alaska: Short papers in the geologic and hydrologic sclences 1961, U. S. Geological survey Professional Paper 424-D, p. D191-D194.

Nichols, D. R., and Yehle, L. A., 1961, Mud volcanoes in the Copper River basin, Alaska, in Raasch, G. D., ed., Geology of the Arctic: University of Toronto Press, Toronto, $v .2$, p. 1063-1087.

Nichols, D. R., and Yehle, L. A., 1969, Engineering geologic map of the southeastern Copper River basin, Alaska: U. S. Geological Survey Miscellaneous Geologic Investigations Map I-524, $1 \mathrm{pl} .$, scale 1:125,000.

Nye, C. J., 1982 , The Wrangell Volcanoes: Voluminous volcanism associated with microplate accretion [abs.]: Geological Society of America, Abstracts with Programs, v. 14, p. 221.

Nye, C. J., 1983, Petrology and geochemistry of Okmok and Wrangell Volcanoes, Alaska: Santa Cruz, California, University of California, unpublished Ph.D. thesis, 208 p.

Nye, C. J., 1986, Volcanic hazards constraints, in Updike, R. G., ed., Engineering geology technical feasibility study, Makushin geothermal power project Unalaska, Alaska: Fairbanks, Alaska Division of Geological \& Geophysical Surveys, Public-data File 86-60, p. El-E15, 1 pl., scale $1: 24,000$.

Nye, C. J., Queen, I. D., and Motyka, R. J., 1984, Geologic map of the Makushin geothermal area, Unalaska Island, Alaska: Falrbanks, Alaska Division of Geological and Geophysical Surveys Report of Investigations $84-3,1$ pl., scale $1: 24,000$.

Nye, C. J., and Reid, M. R., 1986, Geochemistry of primary and least fractionated lavas from okmok volcano, central Aleutians: Implications for arc magmagenesis: Journal of Geophysical Research; v 91, no. B10, p. 10271-10287.

Nye, C. J., Reid, M. R., and GIII, J. B., 1983, High temperature parental magmas from okmok Volcano, central Aleutians: 
Implications for arc magmagenesis [abs.]: EOS, v. 64, p.

Nye, C. J., and Swanson, S. E., 1986, Implications of chemlcal stratigraphy for magmatic plumbing geometry at the Makushin volcanic fleld, central Aleutlans [abs.]: EOS, v. 67, no.
7, p. 86 .

Nye, C. J., and Swanson, S. E., 1987, Geochemical, petrological, and geological constraints on magma chamber geometry and dynamics at the Makushin volcanic field, central Aleutians [abs.]: Hawail symposium on how volcanoes work, Jan. 19-25,
1987, (In press).

Nye, C. J., Swanson, S. E., and Reeder, J. w., 1986, Petrology and geochemlstry of Quaternary volcanic rocks from Makushin Volcano, central Aleutian arc: Fairbanks, Alaska Division of Geological and Geophysicl Survey Public-data File 86-80, 123 p., I pl., scale $1: 50,000$.

Nye, C. J., and Tumer, D. L., 1986, Geology and geochemistry of the Spurr volcanic system, south-central Alaska [abs.]: EOS, v. 67 , no. 44, p. 1276.

ogle, W., 1976, Visit to a number of Alaskan hot springs to aid in the selection of site for the possible instaliation of a small binary geothermal electric generating plant: Report to Federal Energy Research and Development Administration,
51 p.

Okada, H, ' and Okada, A., 1974, The Hot springs V11lage site, preliminary report of the 1972 excavations at Port Moller, Alaska: The Institute for study of North Eurasian Cultures, Hokkaido University, Sapporo, Japan, $20 \mathrm{p}$., $14 \mathrm{pl}$.

Okada, H., and Okada, A., 1980, Prehistory of the Alaska Peninsula as seen from the hot springs site, Port Moller, in Kotani, $Y$, and Workman, W. B., eds., Alaska Native culture and history, Senri Ethnologlcal studies, no. 4: National Museum of Ethnology, Osaka, Japan, p. 103-112.

Okada, H. Okada, A., and Kotani, Y., 1979, The Hot springs V11lage site (3), preliminary report of the 1977 excavations at Port Molier, Alaska: The Institute for study of North Eurasian Cultures, Hokkaido University, Sapporo, Japan, 49

Okada, H., Okada, A., Kotanl, Y, and Hattor1, K., 1976, The Hot Springs Village site (2), preliminary report of the 1974 excavations at Port Moller, Alaska: The Instltute for study of North Eurasian Cultures, Hokkaldo University, Sapporo, 
Okimura, H., 1930, The eruption of Katmai, Alaska 1912: Volcano Letter 305, p. 1-3.

Osterkamp, T. E., Forbes, R. B., Gaffi, R. G., Hanscom, J. T., Kane, M. I., and stephens, C. A., 1979, shallow thermal, electrical conductivity, and hydrologic measurements at Pilgrim Springs, Alaska [abs.]: Proceedings 30th Alaska science Conference, American Association for the Advancement of science, p. 56 .

Osterkamp, T. E., Gosink, J. P., Forbes, R. B., Gaffi, R. G., Hanscom, J. T., Kane, M. I., Stephens, C. A., and KIIne, J. T., 1980, A reconnalssance study of the hydrothermal characteristics and accessible power of pilgrim springs, in Turner, D. I., and Forbes, R. B., eds., Geological and Geophysical study of the geothermal potential of pilgrim Springs, Alaska: Fairbanks, University of Alaska, Geophysical Institute Report, UAG-R-271, p. 113-156.

Page, R. A., Waller, J. A., and stephens, C. D., 1982, Recent seismicity around Spurr, Redoubt, and Illamna volcanoes, southern Alaska [abs.]: Proceedings of 33rd Alaska Science Conference, American Association for the Advancement of Science, p. 129.

Palache, C., 1904, Geology about Chichagof Cove, stepovak Bay; With notes on Popof and Unga Islands (Alaska): Harriman Alaska Expedition, v. 4, p. 69-88.

Parmentler, P. P., Reeder, J. W., and Henning, M. W., 1983, Geology and hydrothermal alteration of Makushin geothermal area, Unalaska Island, Alaska: Geothermal Resources Council Transactions, v. 7, p. 181-185.

Patton, W. W. Jr., 1973, Reconnaissance geology of the northern Yukon-Koyukuk province, Alaska: U. S. Geological survey Professional paper 774-A, $17 \mathrm{p}$.

Patton, W. W. Jr., and Hoare, J. M., 1968, The Kaltag Fault, west-central Alaska: U. S. Geological Survey Research 1968, U. S. Geological Survey Professional Paper 600-D, p. D147D153.

Patton, W. W. Jr., and Miller, T. P., 1966, Reglonal geologic map of the Hughes quadrangle, Alaska: U. S. Geological survey, Miscellaneous Geologic Investigations Map I-459, scale 1:250,000.

Patton, w. W. Jr., and Miller, T. P., 1970, Preliminary geologic investigation in the Kanuti region, Alaska: $U$. S. Geological Survey Bulletin 1312-J, $10 \mathrm{p}$.

Patton, W. W. Jr., Miller, T. P., and Chapman, R. M., and Yeend, W. E., 1978, Geologic map of the Melozitna quadrangle, 
Alaska: U. S. Geological Survey Miscellaneous Geologic Investigations Map I-1071, scale 1:250,000.

Patton, พ. พ. Jr., Milier, T. P., and Tálileur, I. I., 1968, Regional geologic map of the Shungnak and southern part of the Ambler River quadrangles, Alaska: U. S. Geological Survey Miscellaneous Geologic Investigations Map I-554, scale $1: 250,000$.

Pavia, E. A., 1986, Structure and stratigraphy of the northeastern okpilak batholith and Jago River area, Romanzof Mountains, northeastern Brooks Range, Alaska: Fairbanks, Alaska Division of Geological and Geophysical surveys, Public-data File 86-86g, 6 p., 1 pl., scale 1:25,000.

Peale, A. C., 1886, Mineral springs of the United states: U. S. Geological Survey Bulletin 32, 235 p.

Pearson, C. F., 1977, Seismic refraction study of Augustine Volcano, 1977: Falrbanks, University of Alaska, unpublished M.S. thesis, $131 \mathrm{p}$.

Pearson, C. F., and Kienle, J., 1978, A seismic refraction study of Augustine Volcano, Alaska [abs.]: EOS, v. 59, no. 4, p. 311.

Perfit, M. R., Bruechner, H. K., Lawrence, J. R., and Kay, R. W. 1980, Trace element and isotopic variations in a zoned pluton and associated rocks, Unalaska Island: A model for fractionation in the Aleutian calc-alkaline suite: contributions to Mineralogy and Petrology, v. 73, p. 69-87.

Perrey, A., 1866, Documents sur les tremblements de terre et les phenomenes volcaniques des Iles Aleutiennes, de la Peninsula d'Alaska et de la cote No. d'Amerique: Academie des sciences, Arts et Belleslettres, Dijon, Memoir, 2nd. ser., v. 13 , sec. sc., p. 121-151.

Petrov, I., 1884, Alaska, its population, industries, and resources: U.S. Department of Interior, Census office, 10th Census of the U.S., v. 8, p. 19-93.

Pewe, T. I., 1975, Quaternary geology of Alaska: U. S. Geologicai Survey Professional Paper 835, 145 p., 1 pl., scale $1: 2,500,000$.

Poreda, R. J., Craig, H. A., and Motyka, R. J., 1981, Helium isotope variations along the Alaskan-Aleutian arc [abs.]: EOS, v. 62 , no. 45, p. 1082 .

Powers, H. A., 1953, Current activity of Aleutian volcanoes: Volcano Letters, no. 522, p. 6 . 
Powers, H. A., 1956, Activity of Alaskan volcanoes, 1949-1953: Report on Volcanology, 8 th Pacific Science Congress, Quezon city, v. II, p. 21-22.

Powers, H. A., 1958, Alaska Peninsula-Aleutian Islands, in Wililams, H., ed. , Landscapes of Alaska: University of californía Press, p. 61-75.

Powers, S., 1916, Recent changes in Bogoslof volcano: Geological Review, v. 2, p. 218-221.

Prosser, W. T., 1912, Volcanic road-building: Iiterary Digest, v. 44, p. 586-587.

Pulpan, H., and Kienle, J., 1978, selsmic and volcanic risk studies, western Gulf of Alaska: Fairbanks, University of Alaska, Seismological Report no. 3, 93 p.

Queen, I. D., 1984, Iithologic $\log$ and hydrothermal alteration of core from the Makushin Geothermal area, Unalaska, Alaska: Fairbanks, Alaska Division of Geological and Geophysical

Surveys Report of Investigations $84-23,1$ sheet.

Queen, I. D., 1987, Alteration, fluid inclusion, and water-rock equilibrium in the Makushin hydrothermal system, Unalaska Island, Alaska: Falrbanks, University of Alaska, unpublished M.S. thesis, 99 p.

Queen, I. D., and Motyka, R. J., 1984, Changes in the Makushin geothermal system: Evidence from alteration mineralogy [abs.]: Geological society of America, Abstracts with Programs, v. 16, no. 5, p. 329.

Ramdohr, P., 1962, Erzmikroskopische Untersuchungen an Magnetiten der Exhalationen im Valley of 10,000 Smokes: Neues Jahrbuch Mineralogie Monatschrift, v. 1962, n. 3-4, p. 49-59.

Ray, D. K., 1967, Geochemistry and petrology of the Mt. Trident Andesites, Katmai National Monument, Alaska: Fairbanks, University of Alaska, unpublished Ph.D. thesis, $198 \mathrm{p}$.

Ray, D. K., Forbes, R. B., Katsura, T., Matsumoto, H., and Haramura, H., 1966, The petrology and geochemistry of the

( Mount Trident andesites [abs.]: Proceedings of 1ith Pacific Sclence Conference, Tokyo, Japan.

Reck, H., 1930, Das Tal der Zehntausende Dampfe: Zeitschrift Vulkanologie, Band 13, Heft 1, p. 61-65.

Reed, B. I., and Ianphere, M. A., 1972, Generalized geologic map of the Alaska-Aleutian Range batholith showing $K / A r$ ages of the plutonic rocks: U. S. Geological survey Miscellaneous Field studies Map MF-372, 2 pl, scale 1:1,000,000. 
Reed, B. L., and Lanphere, M. A., 1973, Plutonic rocks of the Alaska-Aleutian Range batholith, in Pitcher, M., ed., Arctic Geology: American Association of Petroleum Geologists Memolr 19, p. 421-430.

Reed, B. I., and Lanphere, M. A., 1973, Alaska-Aleut1an Range batholith: geochronology, chemistry, and relation to circum-Pacific plutonism: Geological society of America Bulletin, v. 84, p. 2583-2610.

Reed, M. J., Mariner, R. H., Brook, C. A., and Sorey, M. I., 1983, Selected data for low-temperature (1ess than 90 deg c.) geothermal systems in the United States: Reference data for U. S. Geologícal Survey Circular 892: U. S. Geological Survey Open-file Report $83-250,129$ p.

Reeder, J. W., 1981, Vapor-dominated hydrothermal manifestations on Unalaska Island, and their geologic and tectonic setting [abs.]: - Proceedings of 1981 International Association of Volcanology and Chemistry of the Earth's Interior and Volcanological Soclety of Japan, Symposium on arc volcanism, p. 297-298.

Reeder, J. W., 1981, Initlal assessment of hydrothermal resources of the Summer Bay region on Unalaska Island, Alaska: Geothermal Resources Council Transactions, v. 5, p. 123-126.

Reeder, J. W., 1982, Hydrothermal resources of the northern part of Unalaska Island, Alaska: Fairbanks, Alaska Division of Geological and Geophysical Surveys Open-file Report 163, 17 p.

Reeder, J. W., 1982, The hydrothermal energy potential of the Aleutian arc with an emphasis on the Makushin Volcano region of Unalaska Island [abs:]: Alaska Geologlcal Society, Program and Abstracts, Anchorage, 1982, p. 51-52.

Reeder, J. H. 1982, Hydrothermal resources of the Makushin Volcano region of Unalaska Island, Alaska, in Watson, S. T., ed., Transactions of 3 rd Circum-Pacific Energy and Mineral Resources Conference: Honolulu, Hawa11, 1982, p. 441-450.

Reeder, J. W., 1983 , Preliminary dating of the caldera-forming Holocene volcanic events for the eastern Aleutian Islands [abs.]: Geological Soclety of America, Abstracts with Programs, v. 15 , no. 6, p. 668 .

Reeder, J. W., 1984, Fault and volcanic dike orientations of the Makushin Volcano region of the Aleutian arc [abs.]: International symposium on Recent Crustal Movements of the Paciflc Region, Wellington, New Zealand, 1984, p. 44. 
Reeder, J. W., 1984, Okmok: Bulletin of Volcanic Eruptions, no. 22 , p. $92-94$.

Reeder, J. W., 1986, Ground stability \& springwater geothermal resource assessment of the Makushin (Broad Bay) Valley, in Updike, R. G., ed., Engineering geology technical feasibility study, Makushin geothermal power project Unalaska, Alaska: Fairbanks, Alaska Division of Geological \& Geophysical Surveys, Public-data File 86-60, p. HI-HII, J1-J37, $3 \mathrm{pl}$, scale 1:24,000.

Reeder, J. W., Coonrod, P. I., Bragg, N. J., and Denig-Chakroff, D. N., and Markle, D. R., 1980, Alaska geothermal

implementation plan: Draft prepared by the Alaska

Department of Natural Resources and the Department of Commerce and Economic Development for the U. S. Department of Energy, $108 \mathrm{p}$.

Reeder, J. W., Denig-Chakroff, D. N., and Economides, M. J., 1985, The geology and geothermal resource of the Makushin Volcano region of Unalaska Island, Alaska: Geothermal Resources Council Transactions, v. 6, Part I, p. 479-484.

Reeder, J. W:, Economides, M. J., and Markle, D. R., 1982 , Economic and engineering considerations for geothermal development in the Makushin Volcano region of Unalaska Island, Alaska: Geothermal Resources Council Transactions, v. 6 , p. $386-388$.

Reeder, J. W., Lahr, J. C., Thomas, J., Conens, S., and Blackford, M., 1977, Selsmological aspects of the recent eruption of Augustine Volcano [abs.]: EOS, v. 58, no. 12, p. 1188 .

Reeder, J. W., Motyka, R. J., and Wiltse, M. A., 1980, The State of Alaska Geothermal Program: Geothermal Resources Council Transactions, v. 4, p. 823-826.

Reger, R. D., 1978, Reconnaissance geology of the new capital site and vicinity, Anchorage quadrangle, Alaska: Fairbanks, Alaska Division of Geologlcal and Geophysical Surveys Openflle Report 113A, I pl., scale 1:63,360.

Reger, R. D., and Carver, C. I., 1978, Reconnalssance geologic materials map of the new capital site and vicinity. Anchorage quadrangle: Fairbanks, Alaska Division of Geological and Geophysical Surveys Open-file Report 113B, 1 pl., scale 1:63,360.

Relfenstuhl, R. R., 1984, The Crawflsh Inlet Pluton, Baranof Island, southeastern Alaska: Anatexis or magmatic compositional evolution [abs.]: Geological society of America, Abstracts with Programs, v. 16, no. 5, p. 330. 
Reifenstuhl, R. R., 1984, A geological and geophysical study of the Goddard Hot Springs area, Baranof Island, southeastern Alaska: Fairbanks, University of Alaska, unpublished M.S. thesis, $113 \mathrm{p}$.

Reifenstuhl, R. R., 1986, Geology of the Goddard Hot springs area, Baranof Island, southeastern Alaska: Falrbanks, Alaska Division of Geological and Geophysical surveys, Public-data F1le 86-2, 82 p., l pl., scale 1:63,360.

Reitsema, R. H., 1979, Gases of the mud volcanoes in the Copper River basin, Alaska: Geochimica et cosmochimica Acta, v. 43, p. 183-187.

Republic Geothermal Inc., 1982, The Unalaska geothermal exploration project, phase $1 A$ : RGI Final report prepared for the Alaska Power Authority, 65 p., 13 appendices, 3 pl., scale $1: 24,000 \& 1: 50,000$.

Republic Geothermal Inc., 1983, The Unalaska Geothermal Exploration Project, Phase IB: RGI Final report prepared for the Alaska Power Authority, 160 p., 16 appenalces, 9 pl., scale $1: 24,000 \& 1: 50,000$.

Republ1c Geothermal Inc., 1984, The Unalaska Geothermal Exploration Project, Phase II: RGI Final report prepared for the Alaska Power Authority, 104 p., 13 appendices.

Republ1c Geothermal Inc., 1985, The Unalaska Geothermal Exploration Project, Phase III: RGI Final report Prepared for the Alaska Power Authorlty, 105 p., 11 appendices.

Richter, D. H., 1975, Geologlc map of the Nabesna quadrangle, Alaska: U. S. Geological survey Miscellaneous Fleld studies Map MF-655A, scale 1:250,000.

Richter, D. H., 1976, Geologic map of the Nabesna quadrangel, Alaska: U. S. Geological Survey Miscellaneous Investigations Map I-932, scale $1: 250,000$.

Richter, D. H., Smith, J. G., Ratte, J. C, and Leeman, P. P., 1984, Shield volcanoes in the Wrangell Mountains, Alaska, in Reed, K. M., and Bartsch-Winkler, S., eds., U. S. Geological Survey in Alaska: Accomplishments dunring $1982: U . S$. Geological survey circular 939, p. 71-75.

Richter, D. H., Smith, R. I., Yehle, I. A., and Milier, T. P., 1979, Geologlc map of the Gulkana A-2 quagrangle, Alaska: U. S. Geological Survey Geologic Quadrangle Map GQ-1520, scale $1: 63,360$.

Rlehle, J. R., 1985, A reconnalssance of the major Holocene tephra deposits in the upper cook Inlet region, Alaska: 
Journal of Volcanology and Geothermal Research, v. 26, p. 37-74.

Riehle, J. R., Rienle, J., and Emmel, K. S., 1981, Iahars in the Crescent River valley, lower Cook Inlet, Alaska: Fairbanks, Alaska Division of Geological and Geophysical surveys, Geologic Report 53, 10 p.

Robinson, G. D., 1948, Exploring Aleutlan volcanoes: National Geographic Magazine, v. 94, no. 4, p. 509-522.

Robinson, M. S., and Decker, J., 1986, Preliminary age dates and analytical data for selected igneous rocks from the Sleetmute, Russian Mission, Taylor Mountains, and Bethel quadrangles, southwestern Alaska: Falrbanks, Alaska Division of Geological and Geophysical Surveys, Public-data File 86-99, $8 \mathrm{p}$.

Robinson, M. S., Decker, J., Reifenstuhl, R. R., and Murphy, J. M., 1984, Bedrock geology of the Chuilnuk and Klokluk Mountains, southwest Alaska [abs.]: Geological soclety of America, Cordilleran Section, Abstracts with Programs, $v$. 16 , no. $5, \mathrm{p} .330$.

Robinson, M. S., Decker, J., Reifenstuhl, R. R., Murphy, J. M., and Box, S. E., 1984, Geologic map of the sleetmute B-5 quadrangle: Fairbanks, Alaska Division of Geologic and Geophysical Surveys Report of Investigation 84-10, 1 pl., scale 1:40,000.

Robinson, M. S., Nye, C. J., and Decker, J., 1986, Preliminary whole rock major oxide and trace element geochemistry of selected Igneous rocks from the sleetmute, Russian Mission, and Taylor Mountains quadrangles, southwestern Alaska: Fairbanks, Alaska Division of Geological and Geophysical Surveys, Public-data File 86-98, 8 p.

Robinson, M. S., Reifenstuhl, R. R., Smith, T. E., and Bakke, A., 1986, Preliminary bedrock geologic map of part of the Mt. Michelson c-4 quadrangle, Sadlerochit Mountains, northeastern Alaska: Fairbanks, Alaska Division of Geological and Geophysical Surveys, Public-data File 86-1b, $16 \mathrm{p} ., 1 \mathrm{pl}$., scale 1:25,000.

Robinson, M. S., and stevens, D. I., 1983, Geologic map of the Seward Peninsula, Alaska: Falrbanks, Alaska Division of Geological and Geophysical Surveys Report of Investigations $83-20,1 \mathrm{pl}$., scale $1: 500,000$.

Robinson, M. S., and stevens, D. I., 1984, Geologic map of the Seward Peninsula: Fairbanks, Alaska Division of Geological and Geophysical Surveys in cooperation with the Bering Straits Native Coproration, Special Report $34,1 \mathrm{pl}$, scale $1: 500,000$. 
Roehn, J. C., 1941, Pumice deposits (Katmal National Monument): Alaska Territorial Department of Mines Mineral Investigations $M I 126-1,10 \mathrm{p}$.

Rogers, J. A., 1986, Preliminary bedrock geologic map of the northern central shublik Mountains and Ignek valiey, northeastern Alaska: Falrbanks, Alaska Division of Geological and Geophysical Srveys, Public-data File 86-86a, 15 . ., 1 pl., scale 1:25,000.

Romick, J. D., 1982, The Igneous petrology and geochemistry of northern Akutan Island, Alaska: Fairbanks, University of Alaska, unpublished M.S. thesis, 151 p.

Romick, J. D., 1983, Igneous petrology and geochemistry of northern Akutan Island, Alaska [abs.]: EOS, v. 64, no. 9, p. 90 .

Romick, J. D., 1986, The Igneous petrology and geochemistry of northern Akutan Island, Alaska: Falrbanks, Alaska Division of Geological and Geophysical Surveys, Pubilc-data File 86$52,84 \mathrm{p}$.

Romick, J. D., and Swanson, S. E., 1983, The petrology and fractionation of lavas from Akutan Island, Alaska [abs.]: EOS, v. 64, no. 45, p. 892-3.

Rosenbruch, J. C., and Bottge, R. G., 1975, Geothermal Energy: Economic potential of three sites in Alaska: $U$. S. Bureau of Mines Information Circular $8692,40 \mathrm{p}$.

Rosenthal, F. W., 1908, The hot springs of southeastern Alaska: Alaska Yukon Magazine, v. 4, no. 1, p. 415-416.

Rossman, D. I., 1959, Geology and ore deposits of northwestern Chlchagof Island, Alaska: U. S. Geological Survey Bulletin 1058-E, P. 139-214.

Rubenstone, J. I., Langmuir, C. H., and Hildreth, W., 1985, Isotope and trace element data bearing on the sources and evolution of magmas in the Katmal region, Alaska [abs.]: Geological Society of America, Abstracts with Programs, v. 17. no. 7, p. 710 .

Salnsbury, C. I., Hudson, T. I., Kachadoorian, R., and RIChards, T., 1970, Geology, mineral deposits and geochemical and radiometric anomalies, Serpentine Hot Springs area, Seward Peninsula, Alaska: U. S. Geological Survey Bulletin 1312H, 19 p.

Sainsbury, C. I., Kachadoorian, R., Smith, T. E, and Todd, W. C. . 1968, Cassiterite in gold placers at Humbolt Creek, 
Serpentine-Kougarok area, Seward Peninsula, Alaska: U. s. Geological Survey Circular 565, 7 p.

Sammel, E. A., 1979, Occurrence of low-temperature geothermal water in the U. S., in Muffler, I.J.P., ed., Assessment of geothermal resources of the United States - 1978 : U. $S$. Geological Survey Circular 790, p. 86-131.

Sayre, J. D., and Hagelbarger, P. R., 1918, A study of temperatures in the Valley of Ten Thousand Smokes: Ohio Journal of Science, v. 19, p. 249-278.

Sbar, M. I., and Matumoto, T., 1972, Refraction profiles in the Valley of Ten Thousand Smokes, Ratmai, Alaska: Bulletin Volcanologique, v. 35, no. $2, \mathrm{p} .335-349$.

Scheldegger, R. F., Corliss, J. B., Jezek, P. A., and Ninkovich, D.' 1977, Ash layer record of explosive volcanic eruptions of the Aleutian and Kamchatkan volcanic arcs [abs.]: EOS, v. 58 , no. 12 , p. 1248 .

Scheidegger, K. F., and Kulm, L. D., 1973, Explosive, cyclic Aleutian arc volcanism : Evidence from volcanic ash layers recovered from DSDP site 178, Gulf of Alaska [abs.]: Geological Society of America, Abstracts with Programs, V. 5, no. 7, p. 795 .

Schmincke, H. U., and Johnson, D. A., 1977, Contrasting pyrociastic flow deposits of the 1976 eruption of Augustine Volcano, Alaska [abs.]: Geological Society of America, Abstracts with Programs, v. 9, p. 1161.

Schnell, R. C., and Sheridan, P. J., 1986, Arctic gas and aerosol sampling program (AGASP-II), March-April 1986 [abs.]: EOS, v. 67, no. 44, p. 900

Schrader, F. C., and spencer, A. C., 1901, The geology and mineral resources of a portion of the Copper River district, Alaska: U. S. Government Printing office, special publication, p. $1-94$.

Self, S., Kienle, J., and Huot, J. P., 1978, Mechanisms and deposits of the 1977 Ukinrek maar-forming eruption, Alaska Peninsula [abs.]: Geological Society of America, Geological Association of Canada, and Mineral Association of Canada Meeting, Abstracts with Programs, v. 10, no. 7, p. 489.

Self, S., Kienle, $J_{.}$, and Huot, J. P., 1980, Ukinrek Maars, Alaska II, deposits and formation of the 1977 craters: Journal of Volcanology and Geothermal Research, v. 7, p. 3965.

Shackelford, D. C., 1983, Historical activity of Paviov volcano: Volcano News, no. 14, July 1983; p. 5-6. 
Shelikhov, G. I., 1790 A voyage to America 1783-1786: Ramsay, M., translator, Plerce, R. A., ed., Ilmestone Press 1981, Kingston, Ontario, Canada $163 \mathrm{p}$.

Shipley, J. W., 1919, Valley of Ten Thousand Smokes: Sclence, v. 49 , no. 1277 , p. $489-91$.

Shipley, J.W., 1920, Some chemical observations on the volcanic emanations and incrustations in the Valley of Ten Thousand Smokes, Katmal, Alaska: American Journal of Science, v. 50, p. 141-153.

Shipley, J. W., 1920, Nature of the Katmal volcanic gasses and encrustations: Nature, v. 204, p. 595-597.

Shore, R. A., 1985, Resistivity survey and interpretation: in Republic Geothermal Inc., The Unalaska Geothermal

Exploration Project, Phase III, Final report prepared for Alaska Power Authority, Appendix E.

Slebert, I., Glicken, H., and Klenle, J., 1986, Debris avalanches and lateral blest at Mt. St. Augustine volcano, Alaska [abs.]: EOS, v. 67, no. 44, p. 1259.

Silberman, M. L., Moll, E. J., Chapman, R. M., Patton, W. W. Jr., and Connor, C. L., 1978, Potassium-argon age of granitic and volcanic rocks from the Ruby, Medfra, and adjacent quadrangles, west-central Alaska, in Johnson, $K$. M., and Williams, J. R., eds., U. S. Geological Survey in Alaska: Accomplishments during 1978: U. S. Geological Survey Circular 804-B, p. B63-B66.

simkin, T., siebert, L., Mcclelland, L., Bridge, D., Newhall, c. G. and Iatten, $J$. H., 1981, Volcanoes of the World: Smithsonian Institution, Hutchinson Ross Publishing Co., stroudsberg, Pennsylvania, $232 \mathrm{p}$.

Simons, F. S., and Mathewson, D. E., 1955, Geology of Great sitkin Isiand, Alaska: U. S. Geological survey Bulletin $1028-B$, p. $21-43$.

Sloan, C. E., 1976, Chemical analysis of sample from Balley Bay Hot Spring: U. S. Geological Survey Central Laboratory, Denver, Colorado, Water Quality Analysis File, Lab ID 216065, record 24824 .

sloan, C. E., 1976, Chemical analysis of sample from Bell Island Hot Springs: U. S. Geological Survey Central Laboratory, Denver, Colorado, Water Quality Analysis File, Lab ID 216064 , record 24821 .

sloan, C. E., 1976, Chemical analysis of sample from Chief Shakes Hot Springs: U. S. Geological Survey Central 
GEOTHERMAL BIBLIOGRAPHY

BIBLIOGRAPHY LISTING

Laboratory, Denver, Colorado, Water Quality Analysis File, Lab ID 216063, record 24818.

Smith, R. L., and Shaw, H. R., 1979, Igneous-related geothermal systems, in Muffler, L. J. P., ed., Assessment of geothermal resources of the United States 1978: U. S. Geological survey circular 790, p. 12-17.

Smith, R. L., Shaw, H. R., Luedke, R. G., and Russell, S. I., 1978, Comprehensive tables giving physical data and thermal energy estimates for young Igneous systems of the United States: U. S. Geological Survey Open-file Report 78-925, 28 p.

Smith, w. R., 1925, The Cold Bay Katmai District, In Brooks, A. H., ed., Mineral Resources of Alaska-Report on Progress of Investigation in 1923: U. S. Geological survey Bulletin 773, p. $183-213$.

Smith, พ. R., 1925, Aniakchak Crater, Alaska Peninsula, in Mendenhall, w. c., ed., Shorter contributions to general geology: U. S. Geological Survey Professional Papae 132, p. 139-149.

Smith, พ. R., and Baker, A. A., 1924, The Cold Bay-Chignik district Alaska: U. S. Geological Survey Bulletin 755-D, p. 151-218.

Snyder, G. L., 1954, Eruption of Trident volcano, Katmai National Monument, Alaska, February-June 1953: U. S. Geological Survey Circular 318, p. 318-324.

Snyder, G. I., 1959, Geology of Iittle Sitkin Island, Alaska: U. S. Geological Survey Bulletin 1028-H, p. 169-210.

Snyder, G. L., and Fraser, G. D., 1963, Pillowed lavas, 1: Intrusive layered lava pods and pillowed lavas on Unalaska Island, Alaska: U. S. Geological Survey Professional Paper 454-B, p. B1-B23.

Solle, D. N., 1983, The Middle Fork plutonic complex, Mc Grath A-3 quadrangle, southwest Alaska: Fairbanks, Alaska Division of Geological and Geophysical surveys; Report of Investigations 83-16, $17 \mathrm{p}$.

Sosman, R. B., 1919, The temperature inversions in the fumaroles of the Valley of Ten Thousand Smokes, Alaska Peninsula: Washington Academy of Science Journal, v. 9, p. 292-293.

Spencer, S. G., Long, G. A., and Chapman-Riggsbee, W., 1982, An analysis of geothermal resource development on Unalaska Island, Alaska: Geothermal Resources Council Transactions, v. 6, p. $393-396$. 
Spurr, J. E., 1900, A reconnaissance in southwestern Alaska in 1898: 0. S. Geological Survey 20th Annual Report, v. 7, p. 43-263.

Stearns, N. D., Stearns, H. T., and Waring, G. A., 1937, Thermal springs in the United states: U. S. Geological Survey, Water-supply Paper 679-B, P. 59-206.

Stefano, $R_{\text {, }} R_{\text {. }}$ 1974, Low temperature ut1lizatlon of geothermal water in Alaska at Pligrim Hot Springs: proceedings of General short course on geothermal resources, Boise, Idaho, Avallable form Idaho Dept. of Water Resources, Boise, Idaho, $24 \mathrm{p}$.

Stefano, R. R., 1975, Water from P1Igrim Hot Springs could heat Nome: Alaska Construction \& 0il, February 1975, p. 25-26.

Stern, $R_{\text {. }}$ O., and StIrling, s., 1982, P1lgrim Hot springs Road, Cultural Resources survey, in stern, $R .0 .$, ed., cultural Resources Survey: Alaska Division of Parks, Office of History and Archaelogy, Miscellaneous Publications - History and Archaelogy serles, no. 31, p. 336-348.

Stewart, R. J., 1975, Late Cenozolc explosive eruptions in the Aleutians and Kurll Island arcs: Nature, v. 258, p. 505506.

St1l1, P. J., 1980, Index of stream flow and water-quality records to Sept. 30,1978 , south-central Alaska: U. S. Geological Survey Open-file Report $80-600,54 \mathrm{p}$.

Stith, J. I., Hobbs, P. V., and Radke, I. F., 1977, Observations of a nuée ardente from the st. Augustine volcano:

Geophysical Research Letters, v. 4, no. 7, p. 259-262.

Stoltzfus, C. F., 1982, The Copper River basin reglonal planning model study: Final report for Copper River Native Association, $61 \mathrm{p}$.

Stone, D. B., Anma, K., and Trible, M., 1971, Magnetic anomalies in the Valley of Ten Thousand Smokes [abs.]: EOS, v. 52, no. 11, p. 925 .

stone, D. B., and Kienle, J., 1975, Pavlov: volcanological Soclety of Japan, Bulletin of Volcanic Eruptions, no. 13, p. 50.

Stone, D. B., and Packer, D. R., 1972, Paleomagnetic measurements in the Valiey of Ten Thousand Smokes [abs.]: EOS, v. 53, no. 11, p. 1132 .

Stoney, G, M., 1884 , The new volcano of the Bering sea: science, $v .4$, no. 92, p. 432-434. 
Stoney, G. M., 1900, Naval explorations in Alaska: An account of two naval expeditions in northern Alaska with officlal maps of the country explored: U. $s$. Naval Institute, Annapolis, Md., $105 \mathrm{p}$.

Swanson, S. E., 1983, Mineralogy and fractionation in the Makushin volcanic field, Unalaska, Island, Alaska [abs.]: Geological Society of America, Abstracts with Programs, v. 15, no. $6, \mathrm{p} .703$.

Swanson, S. E., and Blum, J. D., 1984, Evolution of volcanic centers in the Aleutian Arc [abs.]: Geological society of America, Abstracts with Programs, v. 16, p. 671.

Swanson, S. E., Daley, E. E., and Nye, C. J., 1986, Magmatic evolution of Augustine volcano from composition of quenched Iiquid (glass) [abs.]: EOS, v. 67, no. 44, p. 1259.

Swanson, S. E., and Kienle, J., 1982, Volcanic centers In Katmai National Park, Alaska: Faírbanks, University of Alaska, Geophysical Institute Report, 28 p.

Swanson, S. E., Kienle, J., and Fenn, P. M., 1981, Geology and petrology of Raguyak Crater, Alaska [abs.]: EOS, v. 62, p. 1062 .

Swanson, S. E., Nye, C. J., and Motyka, R. J., 1983, Petrology of the Makushin volcanic field, Unalaska Island, Alaska [abs.]: EOS, v. 64, no. 18, p. 335.

Swanson, S. E., Turner, D. L., Forbes, R. B., and Maynard, D., 1980, Bedrock geology of the Pilgrim Springs geothermal area, Alaska, in Turner, D. L., and Forbes, R. B., eds., Geological \& Geophysical study of the geothermal potential of Pilgrim Springs, Alaska: Fairbanks, University of Alaska, Geophysical Institute Report, UAG R-271, p. 7-20.

Taber, J. T., 1972, Selsmicity of geothermal areas, Iceland, El Salvador, Imperial Valley, California, New Mexico, Alaska, Hawail, New Zealand: Socorro, New Mexico, New Mexico Institute of Mines and Technology, unpublished M. S. thesis.

Tams, E., 1924, Erdbeben und aus bruch des Katmai im Jahre 1912: Zeitschrift fur Vulkanologle, v. 8, no.3, p. 137-149.

Thompson, J. M., and Kelth, T. E. C., 1984, Chloride and fluoride in waters draining the Valley of Ten Thousand Smokes, Alaska [abs.]: Geological Society of America, Abstracts with Programs, v. 16, no. 5, p. 336.

Till, A. B., 1984, Redoubt volcano, Cook Inlet, Alaska: stratigraphy and volcanic hazards [abs.]: Geological Society of America, Abstracts with Programs, v. 16, no. 5, p. 337 . 
Turner, D. L., and Forbes, R. B., eds., 1980, A geological and geophysical study of the geothermal energy potential of Pligrim Springs, Alaska: Fairbanks, University of Alaska, Geophysical Institute Report, UAG-271: prepared for $U$.'S. Deptartment of Energy, Division of Geothermal Energy, and Alaska Division of Energy \& Power Development, $165 \mathrm{p}$.

Turner, D. L., Forbes, R. B., Albanese, M. D., Lockhart, A. B., and Seed, S. M., 1980, Geothermal resources of Alaska: Fairbanks, University of Alaska, Geophysical Institute Report UAG-R-279, prepared for U. S. Department of EnergY, Division of Geothermal Energy, $19 \mathrm{p.,} 2 \mathrm{pl}$. scale $1: 2,500,000$.

Turner, D. I., Forbes, R. B., Wescott, E. M., Kienle, J., Osterkamp, T. E., Swanson, S. E., Hawkins, D. B., Harrison, W., Gosink, J. P., KIIne, J. T. 1980 , summary of results of a geological and geophysical investigation of the geothermal energy potential of the Pilgrim Springs area, Alaska: Geothermal Resources Council Transactions, v. 4, p. 93-95.

Turner, D. L., Grybeck, D. G., and W11son, F. H., 2975, Radiometric dates from Alaska: A 1975 compilation: Falrbanks, Alaska Division of Geological and Geophysical Surveys Special Report 10, $64 \mathrm{p}$.

Turner, D. I., and Nye, C. J., 1986, Geochronology of eruptive events at Ht. Spurr, Alaska, In Turner, D. I., and Wescott, E. M., eds., Geothermal energy resource investigations at Mt. Spurr, Alaska: Fairbanks, University of Alaska, Geophysical Institute Report UAG R-308, p. 20-27, 1 pl., scale $1: 2860$.

Turner, D. I., Nye, C. J., Beget, J. E., and wescott, E. M., 1986, The Mt. Spurr, Alaska geothermal energy assessment project: Introduction, geologic overview, and present. geothermal manifestation, in Turner, D. L, and wescott, E. M., eds., Geothermal energy resource Investigations at $M t$. Spurr, Alaska: Fairbanks, University of Alaska, Geophysical Institute Report UAG R-308, p. 7-19, I pl., scale 1:2860.

Turner, D. I., and Swanson, S. E., 1981, Continental rifting - A new tectonic model for the central seward peninsula, in Wescott, E. M., and Turner, D. L., eds., Geothermal reconnalssance survey of the central seward Peninsula, Alaska: Fairbanks, University of Alaska, Geophysical Institute Report, UAG-R-284, p. 7-36.

Turner, D. L., Swanson, S. E., Forbes, R. B., and Maynard, D., 1979, Geology and tectonic setting of Pilgrim Springs, Alaska [abs.]: Proceedings of 30 th Alaska science Conference, American Association for the Advancement of science, p. 52-53. 
Turner, D. I., Swanson, S. E., and Wescott, E. M., 1981, Continental rifting - a new tectonic model for geothermal exploration of the central seward Peninsula: Geothermal Resources Council Transactions, v. 5, p. 213-216.

Turner, D. L., and Wescott, E. M., 1982, A preliminary investigation of the geothermal energy resources of the Iower Susitna Basin: Fairbanks, University of Alaska, Geophysical Institute Report UAG-R-287, 50 p.

Turner, D. L., and Wescott, E. M., eds., Geothermal energy resource investigations at Mt. Spurr, Alaska: Fairbanks, University of Alaska, Geophysical Institute Report UAG R$308,98 \mathrm{p} ., 5 \mathrm{pl}$, scales 1:2860\& 1:6250.

Turner, D. I., Wescott, E. M., and Bratt, D., 1986, Mercury and helium soil surveys at Mt. Spurr, Alaska, in Turner, D. L., and Wescott, E. M., eds., Geothermal energy resource Investigations at Mt. Spurr, Alaska: Fairbanks, University of Alaska, Geophysical Institute Report UAG R-308, p. 66-79, 2 pl., scale 1:6250.

Turner, D. I., Wescott, E. M., Nye, C. J., and Motyka, R. J., 1983, Summary and evaluation of geological, geochemical, and geophysical data relevent to geothermal energy exploration in the eastern Copper River basin, Alaska, in Wescott, $\mathrm{E}$. M., and Turner, D. L., eds., Final report of investigation of the geothermal energy potential of the eastern copper River basin, Alaska: for Alaska Division of Geological \& Geophysical Surveys, RSA 82-5X-67B, p. 1-49.

Twenhofel, W. S., and Sainsbury, C. I., 1958, Fault patterns in southeastern Alaska: Geological Society of America

Bulletin, v. 69 , p. 1431-1442.

Updike, R. G., 1986, Construction materials assessment, in Updike, R. G., ed., Engineering geology technical feasibility study, Makushin geothermal power project Unalaska, Alaska: Fairbanks, Alaska Division of Geological and Geophysical Surveys, Public-data File 86-60, p. K1-K41, $1 \mathrm{pl}$, scale 1:24,000.

Updike, R. G., ed., 1986, Engineering geology, technical feasibility study, Makushin geothermal power project, Unalaska Alaska: Fairbanks, Alaska Diviston of Geological \& Geophysical Surveys, Public-data File 86-60, 261 p., 17 pl., scale 1:24,000.

Veniaminov, I., 1840, Notes on the islands of the Unalaska district: st. Petersburg, Russilsko-Amerikanskol Kompanii, v. 3, p. 21-24. 
Viglino, J. A., Harmon, R. S., Borthwick, J., Nehring, N. I., Motyka, R. J., White, I. D., and Johnson, D. A., 1985, stable-isotope evidence for a magmatic component in fumarole condensates from Augustine Volcano, coóok Inlet, Alaska, USA: Chemical Geology, v. 49, p. 141-157.

VonLangsdorff, G. H., 1814, Voyages and travels in various parts of the world during the years $1803,4,5,6,7 .:$ H. Colburn, Lonton, pt. 1, 368 p., 16 pl., pt. 2, 392 p., 5 pl.

Waldron, H. H., 1961, Geologic reconnalssance of Frosty Peak Volcano and vicinity, Alaska: U. S. Geological survey Bulletin 1028-T, p. 677-708.

wanek, A., 1973, Geothermal areas by meridians and acreages: U. S. Geological Survey for Alaska Land Use Planning Commission, $28 \mathrm{p}$.

Ward, P. I., and Matumoto, T., 1967, A summary of volcanic and seismic activity in Katmai National Monument, Alaska: Bulletin volcanologique, v. 31, p. 107-129.

Ward, P. I., and Ward, S. N., 1966, Volcanic activity in Ratmai National Monument in early August 1965: Earthquake Notes, v. 37 , no. 3 , p. $19-34$.

Waring, G. A., 1917, Mineral springs of Alaska: U. S. Geological Survey Water-Supply Paper 418,214 p.

Waring, G. A., 1965, Thermal springs of the United states and other countries of the world - a summary: U. S. Geological Survey Professional Paper 492,383 p. (revised by Blankenship, R. R., and Bentall, R.).

Wendler, G., 1967, Heat flow by conduction and latent heat in volcanic soll of Mt. Wrangell, Alaska: Pure and Applied Geophysics, v. 68 , no. 3, p. 41-48.

Wescott, E. M., 1981, Helium and mercury surveys, in Wescott, $\mathrm{E}$. M: , and Turner, D. L., eds., Geologlcal and geophysical study of the Chena Hot Springs geothermal Area, Alaska: Fairbanks, University of Alaska, Geophysical Institute Report, UAG-R-283, p. 54-61.

Wescott, E. M., 1981, Helium and mercury in the central seward Peninsula rift system, Alaska, In Ruscetta, C. A. and Foley, D., eds., Geothermal Direct Heat Program: Earth Science Laboratory, University of Utah Research Institute Report ESI-59, P. 63-77.

Wescott, E. M., Sydora, R., and Peace, J. 1979, Resistivity survey of pilgrim Hot springs [abs.]: Proceedings 30 th Alaska Science Conference, American Association for the Advancement of science, p. 55. 
Wescott, E. M., Sydora, R., Peace, J., and Lockhart, A: B., 1980, Electrical resistivity survey of the Pilgrim Springs geothermal area, Alaska: Geothermal Resources Council Transcations, v. 4, p. 257-259.

Wescott, E. H., and Turner, D. L., 1981, A geological and geophysical study of the Chena Hot Springs geothermal Area, Alaska: Fairbanks, University of Alaska, Geophysical Institute Report UAG-R-283, $65 \mathrm{p}$.

Wescott, E. M., and Turner, D. L., 1981, Geothermal reconnaissance survey of the central seward Peninsula, Alaska: Fairbanks, University of Alaska, Geophysical Institute Report UAG-R-284, $123 \mathrm{p}$.

Wescott, E. M., and Turner, D. L., 1982, Geothermal energy resource assessment of parts of Alaska: Fairbanks, University of Alaska, Geophysical Institute final report to U.S. Dept. of Energy, Division of Geothermal Energy, cooperative agreement DE-FC07-79-ET-27034, $69 \mathrm{p}$.

Wescott, E. M., and Turner, D. I., 1983, Geothermal energy resource exploration of the eastern copper River basin, Alaska: Geothermal Resources Council Transcations, v. 7, p. 211-213.

Wescott, E. M., and Turner, D. L., eds., 1983, Final report on the investigation of the geothermal energy resource potential of the eastern Copper River basin, Alaska: Falrbanks, University of Alaska, Geophysical Institute, report to Alaska Division of Geological and Geophysical Surveys, RSA-82-SX-670, 113p., 4 pl., scale 1:63,360.

Wescott, E. M., and Turner, D. I., eds., 1985, Geothermal energy resource investigations in the eastern Copper River basin, Alaska: Fairbanks, University of Alaska, Geophysical Institute Report UAG-R-302, $158 \mathrm{p} ., 8 \mathrm{pl}$, , scale 1:63,360.

Wescott, E. M., Turner, D. I., Motyka, R. J., Witte, W., and Petzinger, B., 1982, Hellum and mercury surveys of parts of Unalaska Island: Falrbanks, University of Alaska, Geophysical Institute report to Alaska Division of Geological and Geophysical surveys, $15 \mathrm{p}$.

Wescott, E. M., Turner, D. I., Nye, C. J., Beget, J. E., and Motyka, R. J., 1985, Preliminary report on geothermal resource investigations at $M t$. Spurr, Alaska: Fairbanks, Alaska Division of Geological and Geophysical Surveys Public-data File, unpublished report $85-65,22$ p.

Wescott, E. M., Turner, D. I., witte, W., and Petzinger, B., 1982, A geophysical survey of Hot Springs Bay Valley, Ajutan 
Island, Alaska: Geothermal Resources Council Transactions, v. 6, p. $185-188$.

Wescott, E. M., and Witte, W., 1982, Gravity survey of lower Susitna basin: Fairbanks, Alaska Division of Geological and Geophysical Surveys Open-flle Report 162,7 p., 2 pl., scale $1: 63,360$.

Wescott, E. M., Witte, W., Moore, P., and Echelmeyer, K., 1986, Ice thickness measurements in the basin surrounding the summit of Mt. Spurr, Alaska, in Turner, D. L., and Wescott, E. M., eds., Geothermal energy resource Investigations at Mt. Spurr, Alaska: Falrbanks, University of Alaska, Geophysical Institute Report UAG R-308, p. 28-40.

Wescott, E. M., Witte, W., Moore, P., and Turner, D. I., 1986, Electrical geophysical surveys for potential geothermal reservoirs on the south side of Mt. Spurr, Alaska, in Turner, D. L., and Wescott, E. M., eds., Geothermal energy resource investigations at Mt. Spurr, Alaska: Fairbanks, University of Alaska, Geophysical Institute Report UAG R308 , p. 41-65, 1 pl., scale $1: 2860$.

Wescott, E. M., Witte, W., and Petzinger, B., 1981, Geophysical surveys of Summer Bay warm springs: Fairbanks, University of Alaska, Geophysical Institute report to Alaska Division of Geological and Geophysical Surveys, 20 p.

Westdahl, F., 1900, Mountains on Unimak Island, Alaska: National Geographic Magazine, v. 14, p. 91-99.

White, D. E., and Willaims, D. L., eds, 1975, Assessment of geothermal resources of the United States $-1975: U$. $S$. Geological survey Circular $726,155 \mathrm{p}$.

Whymper, F., 1868, A Journey from Norton sound, Bering sea to Fort Yukon: Royal Geographic Society Journal, $v .38, p$. 219-237.

Wilcox, R. E., 1953, The eruption of Mount Spurr, Alaska: Volcano Letters, no. 521, p. 8.

Wilcox, R. E., 1959, some effects of recent volcanic ash falls with especial reference to Alaska: U. S. Geological survey Bulletin 1028-N, p. $409-476$.

W11llams, H., 1955, Preliminary notes on the geological work done on Mt. Katmal and in the Valley of Ten Thousand Smokes, Alaska, in Iuntey, R. S., compiler, Interim report on Katmai Project, Katmal National Monument: U. S. National Park service, p. 55-61.

Will lams, H., Curtis, G. H., and Juhle, R. W., 1956, Mount Katmal and the Valley of Ten Thousand Smokes, Alaska (a new 
interpretation of the great eruption of 1912): Proceedings 8th Pacific science Congress, University of Philippines, v. 2, p. 129 .

Williams, J. R., 1985, Engineering geologic map of the southwestern Copper River basin and upper Matanuska River valley, Alaska: 0 . S. Geological Survey Open-file Report 85-143, 2 pl., scale 1:125,000.

Williams, J. R., and Johnson, K. M., 1980, Map and description of late Tertiary and Quaternary deposits, Valdez quadrangle, Alaska: 0 . S. Geological Survey open-file Report 80-892C, 2 pl., scale 1:250,000.

Wilson, C. R., and Forbes, R. B., 1969, Infrasonic waves from Alaskan volcanic eruptions: Journal of Geophysical Research, v. 74, no. 18, p. 4511-4522.

Wilson, C. R., and Forbes, R. B:, 1969, Infrasonic waves from Alaskan volcanic eruptions [abs.]: EOS, v. 50, p. 341.

Wilson, C. R., and Kienle, J., 1976, Infrasonic signals generated by Augustine volcano during the 1976 eruption [abs.]: American Geophysical Union Annual Meeting, Special Augustine Session, April 14, 1976.

Wilson, F. H., 1977, Some plutonic rocks of southwestern Alaska - a data compllation: U. S. Geological survey open-file Report 77-501, 9 p., 4 pl., scale 1:1,000,000.

Wilson, F. H., Detterman, R. L., and Case, J. E., 1985, The Alaska Peninsula terrane: a definition: U. S. Geological Survey Open-file Report 85-450, 19 p.

Wilson, F. H., and Shew, N., 1981, Maps and tables showing preliminary results of potassium-argon age studies in the circle quadrangle, Alaska, with a compilation of previous dating work: U. S. Geological survey Open-file Report 81889, 1 pl., scale 1:250,000.

Wilson, F. H., and Turner, D. L., 1975, Radiometric age map of southeast Alaska: Fairbanks, Alaska Division of Geological and Geophysical Surveys Open-file Report 82, 11 p., 1 pl., scale $1: 1,000,000$.

Wilson, F. H., and Turner, D. L., 1975, Radiometric age map of Aleutian Islands: Fairbanks, Alaska Division of Geological and Geophysical Surveys Open-file Report 83, 10 p., I pl., scale $1: 2,500,000$.

W1Ison, F. H., and Turner, D. I., 1975, Radiometric age map of southwest Alaska: Fairbanks, Alaska Division of Geological and Geophysical Surveys Open-file Report 84, 12 p., 1 pl., scale $1: 1,000,000$. 
WIIson, F. H. and Turner, D. L., 1975, Radlometrlc age map of northern Alaska: Fairbanks, Alaska Division of Geological and Geophysical surveys Open-file 86,11 p., I pl., scale $1: 1,000,000$.

Wilson, F. H., and Turner, D. I., 1975, Radiometric age map of south-central Alaska: Fairbanks, Alaska Division of Geological and Geophysical Surveys Open-file 85, 12 p., 1 pl., scale $1: 1,000,000$.

wiltse, M. A., 1986, Radon hazard assessment orientation survey, Circle Hot springs area, phase 1: Falrbanks, Alaska Division of Geological and Geophysical surveys, Public-data F1le $86-82,11 \mathrm{p}$.

Winkler, G. R., silberman, M. I., Grantz, A., Miller, R. J., and Mac Kevett, E. M. Jr. 1981, Follo of the Valdez quadrangle, Alaska: U. S. Geological survey Open-file Report 80-895-A, 2 pl., scale 1:250,000.

Woodruff, I. G., and Anderson, A. T., 2980, An arrested state of magma mixing, Pavlof Volcano, Alaska: EOS, v. 61, no. $6, p$. 68 .

Woodward-Clyde, 1983, Geothermal energy development at P1Igrim Springs, Alaska: Woodward-Clyde report to Alaska Division of Energy and Power Development, $60 \mathrm{p}$.

Workman, W. B., 1979, The signiflcance of volcanism in the prehistory of subarctic northwest North America, in sheets, P. D., and Grayson, D. R., eds., Volcanic Activity and fluman Ecology: New York, Acadenic Press, p. 339-371.

Wright, C. W., 1906, Nonmetallic deposits of southeastern Alaska, in Brooks, A., ed., Report on progress of investigations of mineral resources of Alaska: $U$. $s$. Geological Survey Bulletin 284, p. 55-60.

Wright, F. E., and wright, C. W., 1908, The Ketchikan and Wrangell mining districts, Alaska: U. s. Geological survey Bulletin $347,210 \mathrm{p}$.

Yehle, I. A. and Nichols, D. R., 1980, Reconnalssance map and description of the Chetasilna volcanic debris flow (new name), southeastern Copper RIver Basin and Adjacent areas; south central Alaska: U. S. Geological survey, Miscellaneous Field study Map MF-1209, scale 1:250,000.

Yehle, I. A., Odum, J. K., and Reneau, D., 1985, Generallzed interpretation of geologic materials from shot holes drilled for the Trans-Alaska crustal transect project, Copper River basin and adjacent regions, Alaska, May-June 1984: U. S. Geological survey Open-file Report $85-582,35 \mathrm{p}$. 
Yount, M. E., 1984, Redoubt Volcano, Cook Inlet, Alaska, mineralogy and chemistry [abs.]: Geological society of America, Abstracts with Programs, v. 16, no. 5, p. 340 .

Yount, M. E., Miller, T. P., Emanuel, R. P., and Wilson, F.H., 1985, Eruption in an 1ce-filled caldera, Mount Veniaminof, Alaska Peninsula, in Bartsch-Winkler, S., and Reed, K. M., eds.. The U. S. Geological survey in Alaska:

Accomplishments in 1983: U. S. Geological Survey Circular 945 , p. 60-62.

Yount, M. E., Wilson, F. H., and Miller, J. W., 1985, Newly discovered Holocene volcanic vents, Port Moller and stepovak Bay quadrangles, In Bartsch-Winkler, S., and Reed, K. M., eds., U. S. Geological Survey in Alaska: Accomplishments during 1983: U. S. Geological survey Circular 945, p. 6062.

Zies, E. G., 1921, Hot springs of the Valley of Ten Thousand Smokes: Journal of Geology, v. 32, no. 4, p. 302-310.

zies, E. G., 1924, Fumarolic incrustations in the Katmai Region [abs.]: Geological Society of America Bulletin, v. 35, no. i, p. 123 .

zies, E. G., 1924, The fumarolic incrustations in the valley of Ten Thousand Smokes: National Geographic Society, Contributed Technical Papers, Katmai Series 3, p. 159-179.

zies, E. G., 1929, The Valley of Ten Thousand smokes: I The fumarolic Incrustations and the bearing ore deposition. II The acld gases contributed to the sea during volcanic activity: National Geographic society, Contributed Technical Papers, Katmai series, v. 4, p. 1-79. 


\title{
ALASKA GEOTHERMAL BIBLIOGRAPHY
}

\section{SECTION II}

\author{
AUTHOR IISTING
}

\section{(see Table I - Abbreviations used in short references - Pg. 223)} (see Table II - Codes used in short references - Pg. 227) 
AUTHOR

Abramson, B. S.

Gassaway \& Abramson 1977 Map \& table thermal springs cntr Ak R,Fs Ach, J.

Ach \& DeLong 1980 Magma evo L. Sitkin \& Semisopochnol [abs.] PG Adams, D: D.

Adams $1983 \mathrm{Geol}$ northern Arrigetch pluton (thesis)

Adams 1984 Geol northern Arrigetch Peaks pluton [abs.]

Dillon \& others 1983 Geol map Melozitna A-4 Quad

Adler, P.

Dillon \& others 1983 Geol map Melozitna A-4 Quad

Alaska Geological Consultants

AGS 1975 Drum thermal springs area

Albanese, M. D.

Turner \& Others 1980 Geothermal resources Alaska

Allaway, พ. H. Jr.

Detterman \& others 1983 Geol map Ugashik-Bristol Bay-Karluk \& Gr Allely, R. D.

Allely 1986 Seismic refraction Makushin

Motyka \& others 1985 Geol geoc geophys Akutan *,Gs, Fs, Ps, RM, Ff, DP Allen, E. T.

Allen \& Zies 1923 Chem study fumaroles Katmai region

Anderson, A. T.

4. Woodruff Anderson 1980 Arrested magma mixing Pavlov

Andreasen, G. E.

(1. Andreasen \& others 1958 Aeromag Copper River basin

Andreasen \& others 1964 Geol inter mag \& grav Copper Rvr basn Pr Anma, $K$.

Anma 1971 Aeromag survey VTTS (thesis)

Stone others 1971 Magnetic anomalies VTTS [abs.] 
Anonymous

Anonymous 1953 Activity of Trident

Anonymous 1953 Eruption of Trident

Anonymous $1975 \mathrm{Ak}$ regional profiles SW region

Anonymous 1982 Reed River Hot Springs

Ansar1, $\mathrm{J}$.

Economides others 1982 Eng,geol anal geothermal sites EF,Er

Arce, G. N.

Arce 1983 Volcanic hazards Makushin Volcano (thesis)

Arce \& Economldes 1982 Volcanic hazards Makushin Volcano

Economides \& Arce 1983 Geothermal in AK - eng \& geol anal

Economides \& others 1982 Eng,geol anal geothermal sites

Bader, J. W.

Bader 1984 Geol map eastern N. slope Ak.

Gr

Bader \& Blrd 1986 Geol map NE Alaska

Baker, A. A.

Smith \& Baker 1924 Cold Bay-Chignik dist

Baker, D. R.

Baker \& Eggler 1983 Atka high alumina basalt

Baker, R. 0 .

Baker \& others 1977 Geotherm springs-salmon hatchery site R,DP,Fs Bakke, A.

Robinson \& others 1986 Geol map Mt. Mlchelson C-4 Quad

Bamford, R. W.

Isselhardt others 1983 Temp grads Makushin geothermal area HS Barnes, D. F.

Andreasen \& others 1964 Geol Inter mag \& grav Copper Rvr basn Pr Barnes, Ivan

Barnes \& McCoy 1979 Mantle-derived CO2 in 2 phreatic expl Fs,Ff,V Barnes Miller 1974 Geotherm studies in Alaska [abs.] Miller \& Barnes 1974 Geotherm devel Ak [abs.] Miller \& Barnes 1976 Geotherm develop Ak summary Miller \& others 1975 Geol \& chem hot springs $W$ cent Ak $\mathrm{DP}, \mathrm{Gr}, \mathrm{V}$ $D P, G r, V$ R, Fs 
AUTHOR

Barnett, H. F. Jr.

Drewes \& others 1961 Geol Unalaska \& adjacent shelf

Fraser \& Barnett 1959 Geol Delarof \& Andreanof Islands

Gr

Gr

Barnwe11, พ. W.

Barnwe11 \& Pearson 1984 Ak resource inventory

DP

Barrett, s. A.

Barrett 1978 Magnetic model of Augustine Volcano (thesis)

Barrett \& others 1977 Model of Augustine Volcano [abs.]

Kienle \& others 1979 shallow magma at Augustine

$\mathrm{V}, \mathrm{Ps}$

$\mathrm{V}, \mathrm{Ps}$

Barth, T. F. W.

Byers \& Barth 1948 Geol Akutan Island

Byers \& Barth 1953 Volc activity Akun \& Akutan Islands

Gr

Basecu, N.

Basecu 1980 Geothermal in Alaska

Beaglehole, J. C.

Beaglehole 1967 Journals of Captain James Cook

Beavan, R. J.

McNutt \& Beavan 1981 Quakes at Pavlov earth tides

MoNutt \& Beavan 1984 Pavlov sea level \& aseismic slip [abs.]

Becker, G. F.

Becker 1898 Recon of goldfields southern Alaska

Beebee, J.

Beebee \& Kirkwood 1979 Unalaska-geothermal prospects

i. Beget, J. E.

Beget 1986 Prehistoric tephra at Augustine [abs.]

Ilmke \& Beget 1986 Pyroclastic flows Augustine [abs.]

Turner \& others $1986 \mathrm{Mt}$. Spurr geothermal project

Wescott \& others 1985 Prelim rept gthrml invest Mt spurr Gs,Ps,Gc

Belkman, H. M.

Beljman 1974 Prelim geol map SE Quad of Alaska

Beikman 1974 Prelim geol map sw Quad Alaska

Belkman 1975 Prelim geol map SE Alaska 
Beikman 1980 Geologic map of Alaska Belkman \& Lathram 1975 Prelim geol map N Ak

Eberlein \& others 1977 Prelin geol map central Alaska

Benson, C. S.

Benson \& Follett 1986 Photogrammetry study Mt. Wrangell

Benson \& Motyka 1978 Glac-volc interaction Mt. Wrangell

Benson \& others 1975 Glac volc studies Mt. Wrangell

Benson \& others 1985 Glacio-volcano studies Mt. Wrangell

Bingham \& Benson $1967 \mathrm{Mt}$. Wrangell ice \& heat studies

Bingham \& Benson 1968 Ash temp varlations Mt wrangell

Motyka \& Benson 1982 Flucts in heat flow Mt Wrangell [abs.]

Motyka \& others 1977 Glac-volc investigations Katmai [abs.]

Motyka \& others 1978 Increased heat Mt Wrangell [abs.]

Motyka \& others 1980 Mt Wrangell glac meas heat flow [abs.] V, HS

Berg, E.

Berg \& Keinle 1966 Gravity meas Katmal volc area

Berg \& others 1967 Crustal structure - Katmai

Kubota \& Berg 1967 Magma in Katma1 range

Berg, H. C.

Berg Hinckley 1963 Recon geol northern Baranof Is. Gr Berg \& others 1978 Geol map Ketchikan \& Prince Rupert Q Ak. Gr Eberlein \& others 1983 Geol map Craig Q Loney \& others 1963 Recon geol map Chichagof \& NW Baranof Is Gr Monger \& Berg 2985 Terrane map SE Ak. \&. Can.

Berry, G. W.

Berry \& others 1980 Thermal spring list U.S.

Biggar, N. E.

Biggar 1974 Geol geophys stdy at Chena HS (thesis) Gs, Ps, Fs, FW Forbes \& Biggar 1973 Ak geothermal resource potential $R$, HS

Bingham, D. $\mathrm{K}$.

Benson \& others 1975 Glac \& volc studies Mt. Wrangell

Benson \& others 1985 Glaclo-volcano studies Mt. Wrangell

Bingham 1967 Ice \& heat studies Mt. Wrangell (thesis)

Bingham \& Benson $1967 \mathrm{Mt}$. Wrangell lce \& heat studies

Bingham \& Benson 1968 Ash temp variations Mt Wrangell

Kienle others 1970 seism evidence pre 1912 tuff VTTS [abs.]

Bird, K. J.

Bader \& Bird 1986 Geol map NE Alaska

Gr 
Black, R. F.

Black 1974 Geol \& ancient Aleuts

Black 1974 Late Quat sea level changes Umnak. Is

Gr

Black 1975 Late Quat geomorph Umnak Is

Black 1976 Geol Umnak related to Aleuts

.

Black 1980 Movements sea level Aleutian Is

Black 1981 Holo sea level changes Aleutian Islands

Black 1981 Late Quat climatic changes Aleutian Islands

Black 1983 Glacial chronology Aleutians

Blackford, $\mathrm{M}$.

Reeder \& others 1977 Seism Augustine volc [abs.]

Blackwe11, D. D.

Blackwell \& steele $1986 \mathrm{NA}$ geothermal map [abs.]

$R$, HS

Blanchard, D. C.

Blanchard \& Tallleur 1982 Prelin geothermal 1sograd map NPRA

HS Bliss, J. P.

Bliss 1983 Ak basic data thermal springs \& wells $R, F s, F w$

Blodgett, R. B.

Blodgett \& G1lbert 1983 Cheeneetnuk limestone Mc Grath

Blum, J. D.

Swanson \& Blum 1984 Evol of volc centers Aleutian arc [abs] $V, G r$

Borchert, $\boldsymbol{M}$.

Gosink \& others 1986 Augustine ash [abs.]

Bordet, P.

Bordet \& Tazleff 1963 Erupt of Katmal \& ignimbrites Bordet \& others 1963 Katma1

Chaigneau Bordet 1963 Gas in glass in VTTS (Fr)

Borthwick, J.

Harmon o others 1982 Isotopes from Augustine fumaroles

Viglino others 1985 Isot evid magma comp in fum cond Augst $V, F f$

Bottge, R. G.

Rosenbruch \& Bottge 1975 Econ potent 3 sites Ak 
AUTHOR

TOPIC

Bowen, P. A.

Nehring others 1979 sulfate geotherm western U. S. R, Fs

Box, S. E.

Robinson \& others 1984 Geologic map sleetmute B-5 Q Gr

Boyd, T. $M$.

Boyd \& Jacob 1984 Seismicity of Unalaska

Jacob \& Boyd 1985 Seismic network on Unalaska

Pr

$\operatorname{Pr}$

Brabb, E. E.

Foster \& others 1970 Geol Yukon-Tanana upland [abs.] Gr

Foster \& others 1973 GeologY Yukon-Tanana upland Gr

Bragg, N. J.

Reeder others 1980 Geothermal implementation plan DP

Brannock, W. W.

Byers \& Brannock 1949 Volc activity Umak \& Great Sitkin Is

Bratt, D.

Turner \& others $1986 \mathrm{Hg}$ and He surveys Mt. Spurr

Brew; D. A.

Brew \& Ford 1985 Geol map Juneau, Taku, Atlin, Skag Quad

Brew \& others 1965 Eruptive history Mt. Edgecumbe [abs.]

Gr

Brew \& others 1969 Recon geol Mt Edgecumbe

Brew \& others 1984 Geologic map Peterbrg, Sumdum, P. Alex

Loney \& others 1963 Recon geol map Chichagof \& NW Baranof Is

Loney \& others 1964 Recon geol map Baranof \& Kruzof Is

Loney \& others 1967 Radio ages \& fault movements N SE AK

Loney \& others 1975 Recon geol Chichagof, Baranof \& Rruzof Is Gr

Bridge, D.

Simkin \& others 1981 Volcanoes of the World

Britch, R. P.

Baker \& others 1977 Geotherm springs-salmon hatchery site R,DP,Fs Brook, C. A.

Brook \& others 1979 Hydrothermal systems $<90$ deg R,Fs Mariner \& others 1978 Data for hydrothermal systems $>=90$ R, Fs Reed \& others 1983 Data low temp geothermal systems US HS,R,Fs 
AUTHOR

TOPIC

Brophy, J. G.

Brophy \&arsh 1984 Petro \& geochem Cold Bay volc [abs.] PG

Brosge, W. P.

Brosge \& Patton 1982 Bedrock geol maps Dalton fwy Gr

Brosge \& Pessel 1977 Prelim recon geol map survey Pass $Q$ Gr

Chapman others 1975 Prelim geol map Tanana NE Kantishan $Q$ Gr

Chapman \& others 1982 Recon geol map Tanana $Q \quad \mathrm{Gr}$

Brown, J. S.

Brown 1899 shishaldin

H

Bruechner, H. K.

Perfit o others 1980 Model for fract in Aleut calc-alk suite PG

- Buddington, A. F.

Buddington \& Chapin 1929 Geol \& mineral deposits SE AK

Bundtzen, T. K.

Bundtzen \& Gilbert 1983 Geology upper Kuskokwim

Bundtzen Kline 1986 Coal, peat geotherm in Kuskokwim

Bunker, C. M.

Bunker \& others 1977 Prelim radio ages of rocks Kigluaik Mts

Gr

Burk, C. A.

Burk 1965 Geol Ak Penin-island arc \& continental margin

Gr

Buzzell, R. G.

Buzzell Gibson 1986 Nome-Taylor Rd. cultural resources

c Byers, F. M. Jr.

Byers 1959 Geol Umnak \& Bogoslof Islands

Byers 1961 Petro 3 volc suites Umnak \& Bogoslof Islands

Gr

Byers \& Barth 1948 Geol Akutan Island

Byers \& Barth 1953 Volc activity Akun \& Akutan Islands

Byers \& Brannock 1949 Volc activity Umnak \& Great sitkin Is

PG

Gr

V

Cady, W. M.

Cady \& others 1955 Geology central Kuskokwim 
Campbell, D. A.

Campbell E Economides 1984 Summary Well no. 1 Makushin volc Er Economides \& others 1985 Eval Makushin geothermal reservolr Er

Capps, S. R.

Capps 1934 Notes geol Ak Penin \& Aleutian Islands Gr Capps 1935 Southern Alaska Range

Carey, D. I.

Carey \& others 1983 Unalaska geotherm land, regs, \& environ DP Carrick, s.

Carrick \& Maurer 1986 Hydrology - Makushin

carter, $c$.

Eberlein \& others 1983 Geol map Craig Q

Carter, L. D.

Carter \& Galloway 1978 Geol map proposed gas line

Gr

Carver, c. I.

Reger \& Carver 1978 Recon geol materials map capital site Gr Case, J. E.

Case \& others 1980 Tertlary volc centers Ak Penin.

Detterman \& others 1983 Geol map Ugashik-Bristol Bay-Karluk \& $G r, v$

Wilson \& others 1985 Alaska Peninsula terrane

Cass, J. T.

Cass 1959 Recon geol map Melozitna Q Ak.

Chaigneau, $M$.

Chaigneau \& Bordet 1963 Gas In glass in VTTS (Fr) P,V Chapin, T.

Buddington \& Chapin 1929 Geol \& mineral deposits SE Ak Gr Chapman, R. M.

Chapman \& others 1975 Prelim geol map Tanana \& NE Kantishan Q Gr Chapman \& others 1982 Recon geol map Tanana $Q$ Patton \& others 1978 Geol map Melozitna Q Sllberman \& others 1978 Age of rocks Ruby, Medfra \& adj Q 
AUTHOR

TOPIC

Chapman-RIggsbee, $\%$.

Spencer \& others 1982 Anal geothrm res devel Unalaska

EF, DP

Chuan, $\mathbf{R}$.

Gosink \& others 1986 Augustine ash [abs.]

Church, R. E.

Church \& others 1970 Copper River basin strat correl section

Gs

Churkin, M. Jr.

Eberlein \& others 1983 Geol map Craig Q

Gr

citron, G. P.

Ray \& others 1982 Tectonic control of magmatism Aleut arc

clark, G. A.

Clark 1912 Ratmai eruption

$\mathrm{V}, \mathrm{H}$

Coats, R. R.

Coats 1947 Geol N Adak Island

Coats 1947 Geol N Kanaga Is.

Coats 1950 Volc activity Aleutian arc

Coats 1952 Magmatic different Adak \& Kanaga Islands

Coats 1953 Geol Buldir Island

Coats 1956 Geol N Adak Island

Coats 1956 Geol N Kanaga Island

Coats 1956 Recon geol W Aleutian Islands

Coats 1959 Geol recon Garelol Island

Coats 1959 Geol recon Semisopochnoi Island

Coats 1962 Magma type \& crustal structure Aleutian arc

Coats \& Marsh 1984 Recon geol \& petrol N Tanaga [abs.]

Coats \& others 1961 Geol recon Kiska Island

Collazzi, E. J.

Collazz1 \& Ireland 1986 Hydrology lower Ruskokwim basin

Gr

Collier, A. J.

Collier 1902 Recon NW Seward Penin

$\mathrm{H}, \mathbf{G r}$

Combellick, R. A.

Combelilck 1986 Eng geol power plant site Makushin 
Condon, W. H.

Ioney others 1963 Geol Freshwater Bay Chichagof Is Gr conens, s.

Reeder \& others 1977 Seism Augustine volc [abs.] V,Ps Coney, P. J.

Jones \& others 1984 Terrane map Alaska

Connor, C. I.

Silberman \& others 1978 Age of rocks Ruby, Medfra \& adj $Q$ Gr conrad, W. K.

Conrad \& Kay 1984 . Inclusions Adak Is-nature of primary magma PG Conwe11, C. N.

Conwell \& Schell 1977 Energy resource map Alaska

coonrad, W. I.

Decker \& others 1984 Geology sleetmute B-5 Quad

Hoare \& Coonrad 1959 Geol map Russian M1ssion Quad

coonrod, P. I.

Emmel \& Coonrod 1982 Geol Iiterature Copper River basin Gr

Reeder \& others 1980 Geothermal implementation plan

Córl1ss, J. B.

scheldegger others 1977 Ash volc Aleut \& Kamchat arc [abs.] V Corwin, R. F.

Corwin \& Fitterman 1983 self potential Makushin geotherm area Ps Coulter, H. W.

Juhle \& Coulter 1955 Mt. Spurr eruption 1953

Muller \& others 1954 volcanic activity Katmal

Craig, H. A.,

Poreda others 1981 He isot vars Ak-Aleut arc [abs.]. R,Fs,Ff Crick, R. W.

Church \& others 1970 Copper River basin strat correl section Gs 
Curtis, G. H.

Curtis 1955 Importance of Novarupta [abs.]

Curtis 1968 stratigraphy of ejecta 1912 eruption Katmai

Williams \& others 1956 Mt Katmal \& VTS new Interp 1912 eruptn

Cushing, G. W.

Foster \& others 1983 Geologic map Circle $Q$

\& Foster \& others 1983 Prelim geol map Circle Quad

Dally, I. $\mathrm{K}$.

Da11y, 1912 Eruption of Ratmai

Daley, E. E.

Daley 1986 Petro, geochem \& evol magmas Augustine (thesis)

Daley \& Swanson 1985 Low press fractionation Augustine [abs.]

Swanson \& others 1986 Magmatic evolution Augustine [abs.] $P G, V$

Dal1, W. H.

Dall 1870 Alaska and its resources

Dall 1870 Bogosloff volcano

Dall 1884 New volcano island

Dall 1889 Notes on Bogoslof island

Dames and Moore

Dames \& Moore 1980 Geothermal drilling studies Unalaska

Davidson, G.

Davidson 1884 First ascent Makushin

Davidson 1884 New Bogoslof volcano

Davidson 1884 New volcano in Alaska

Davies, J. N.

Davies 1986 Seismic hazards - Makushin

Davies \& Kienle 1986 Augustine eruption \& advice [abs.]

Eg, Ps

House \& others 1981 Selsmic gap near Unalaska

Nakamura \& others 1977 Volc tectonic stress orient Aleut \& A

Davydov, G. I.

Davydov 1809 Voyages to Russian America 1802-1807 
DeIong, S. E.

Ach \& Delong 1980 Magma evo I. Sitkin \& semisopochnol [abs.] PG Dean, K. G.

Dean \& others 1981 Remote sensing Pilgrim Springs

Decker, J.

Decker 1980 Geol Cret. subduct complx Chlchagof Is (thesis) Gr

Decker 1980 Geol map W Chlchagof Island

Decker 1984 Kuskokwim group

Decker \& Hoare 1982 Cretaceous Kuskokwim Group

Decker others 1984 Geol data Russian Mission A-3 Quad

Decker others 1984 Geology sleetmute B-5 Quad

Robinson \& Decker 1986 Ages analysis from SW Alaska

Robinson others 1984 Bdrck geol Chuilnuk \& Klokluk Mts [abs] Gr

Robinson others 1984 Geologic map sleetmute B-5 Q Gr

Robinson others 1986 Rocks from sleetmute, Russian Mission Q PG

Decker, R. $\boldsymbol{W}$.

Decker 1964 Geophys investigations Katmal [abs.]

Decker 1967 Invest at active volcanoes

Dejong, P. K.

Carey others 1983 Unalaska geotherm land, regs, \& environ

DP

Dempsen, $\dot{W}$.

Andreasen \& others 1958 Aeromag Copper River basin

Pr

Denig-Chakroff, D. N.

Denig-Chakroff 1985 Unalaska recon study EF

Denig-Chakroff \& others 1985 Development pot Mak reservoir Er,DP Reeder \& others 1980 Geothermal implementation plan

Reeder \& others 1985 Geol geotherm resource Makushin

R, Gs

Detterman, R. I.

Case \& others 1980 Tertlary volc centers Ak Penin. Detterman 1968 Volcanic activity Augustine Island Detterman 1973 Geol map Illamna B-2 Quad Augustine Island Gr Detterman \& Hartsock 1966 Geol Iniskin-Tuxedni region Gr Detterman \& Reed 1964 Prelim geol map Iliamna $Q \quad$ Gr Detterman \& Reed 1968 Geol Il lamna $Q \quad$ Gr Detterman Reed 1973 Surficial deposits Illamna $Q \quad$ Gr Detterman \& Reed 1980 strat, struct, econ geol Illamna $Q$ Gr Detterman others 1976 Geol map by faults in Renal \& Tyonek $Q \mathrm{Gr}$ Detterman \& others 1979 Geol map Chignik \& Sutwik Is Q Gr Detterman \& others 1981 Geol map Chignik \& Sutwik Is $Q$ 
AUTHOR

Detterman \& others 1981 Quat geol map Chignik \& Sutwik Is Q Gr Detterman \& others 1983 Geol map Ugashik-Bristol Bay-Karluk Q Gr Detterman \& others 1985 Geol map Ugashik \& W Karluk Q Gr - Detterman \& others 1986 Quat map Ugashik-Bristol Bay-Karluk Q Gr Johnson \& Detterman 1979 Revision of eruptive history Augustine V wilson \& others 1985 Alaska Peninsula terrane

Dickey, D. B.

Dickey 1983 Tertlary seds \& tectonics Farewell fault area Gs,PG Dickey 1984 Cenozoic rocks Farewell area

Dickey \& others 1982 Cenozoic seds \& Farewell fault

Gr

*..

Diller, J. S.

Diller 1884 Volcanic sand Unalaska

Diller 1893 our youngest volcano

$\mathrm{H}, \mathrm{V}$

$\mathbf{H}$

Dillon, J. T.

:Dillon \& others 1983 Geol map Melozitna A-4 Quad

Dinkel, D. H.

Forbes \& others 1975 Utilization geothermal rural Ak Fs,DP,Ef Forbes \& others 1975 Utilization of Alaska thermal springs DP

Dixon, J. P.

Dixon \& Pulpan 1986 Crustal structure-Dall City [abs.] Ps

Dobey, P. L.

Lyle \& Dobey 1974 Geol evaluation Herendeen Bay area Gr

Doroshin, P.

Doroshin 1870 Volcanoes, eruptions \& earthquakes H Dover, J. H.

*Dover \& Mayaoka 1985 Rocks Ray Mts, Tanana \& Bettles $Q \quad$ Gr

Drewes, H.

- Drewes \& others 1961 Geol Unalaska \& adjacent shelf Gr

Dumon, D. E.

Dumond 1979 People \& pumice Ak Penin. V,C

Dunn, R.

Dunn 1909 Conquering Mt wrangell 
Dutro, J. T. Jr.

Loney \& others 1963 Geol Freshwater Bay Chichagof Is

Eakins, G. R.

Eakins 1969 Sulfur deposit stepovak Bay [abs.]

East, J..S.

East 1982 Geotherm investigation Manley HS (thesis) Fs,Fw,Gs,Ps

East 1982 Prelim geothermal investigation Manley HS Gs, Ps, Fs

Eaton, F. D.

Dean \& others 1981 Remote sensing Pilgrim Springs

PS

Eberlein, G. D.

Eberlein \& others 1977 Prelim geol map central Alaska Gr Eberlein \& others 1983 Geol map Craig Q

Echelmeyer, $\mathrm{K}$.

Wescott \& others 1986 Ice thickness Mt. Spurr summit Ps

Economides, C. E.

Economides \& others 1982 Reservoir eng analysis Pilgrim Sprg Er

Economides, M. J.

Arce \& Economides 1982 Volcanic hazards Makushin Volcano

Campbell Economides 1984 Summary Well no. 1 Makushin volc

Denlg-Chakroff \& others 1985 Development pot Mak reservoir

Economides \& Arce 1983 Geothermal in AK - eng geol anal EF, Ex

Economides \& others 1981 Unalaska geothermal development

Economides \& others 1982 Eng,geol anal geothermal sites

Economides \& others 1985 Eval Makushin geothermal reservoir Er

Reeder \& others 1982 Econ \& eng geoth develop Makushin EF,Eg, DP

Reeder \& others 1985 Geol geotherm resource Makushin

Edsal1, D. W.

Edsall 1976 Trace elem in tephra Aleutlans

Eggler, D. H.

Baker \& Eggler 1983 Atka high alumina basalt

Elckelberger, J. C.

Eickelberger \& Hldreth 1986 Drilling in Katmal [abs.] V,Gs,Ps 
AUTHOR

Elliott, R. I.

Berg others 1978 Geol map Ketchlkan \& Prince Rupert Q Ak. Gr Milier \& others 1972 Prelim geol map Solomon \&E Bendeleben $Q \mathrm{Gr}$ Emanuel, R. P.

Emanuel 1984 Hydro \& volc hazards Mt Spurr [abs.]

Yount \& others 1985 Eruption Mt Venianinof

Emery, P.

Emery \& Jones 1984 Hydrologic atlas Copper River basin

Gs

Emmel, K. S.

Emmel \& Coonrod 1982 Geol Iiterature Copper River basin

Riehle \& others 1981 Lahars Crescent River Lower Cook Inlet

England, J. M.

Longenkamp \& others 1974 Elec resist survey Pilgrim springs Ps Escher, B. G.

Escher 1922 Lahar VTTS

Estes, S. A.

Estes 1978 Seismotectonic studies lower cook Inlet (thesis) Pr

Kienle others 1978 Formation 2 maars Ak Penin prelim results V Evans, W.

Motyka \& others 1986 Augustine gas sampling [abs.] Ff Federman, A. N. (.)

Federman \& Scheldegger 1984 Distal tephra 1912 Novarupta Fenn, P. M.

Swanson \& others 1981 Geol \& petro Kaguyak Crater [abs.] PG Fenner, c. N.

Fenner 1920 Geol Katmal 1912 eruption [abs.]

Fenner 1920 Katmai great eruption of 1912

Fenner 1923 Tuff deposit VTTS

Fenner 1923 Tuff deposit VTTS

Fenner 1926 Katmai magmatic province

Fenner 1930 Kt Ratmai \& Mt Mageik 
Fenner 1937 Tuffs of Katmai \& Yellowstone

Fenner 1950 Chemical kinetics Katmal eruption

Ferrell, V. M.

Motyka others 1977 Glac-volc investigations Katmal [abs.]

Ferrians, O. J. Jr.

Ferrians \&1chols 1965 Copper River basin

Gr

Ferrians schmoll 1957 Wlsc progalcial lake Copper River bsn Gr Ferrians others 1958 plelst volc mudflow Copper River basin $v$ Ferrians others 1983 Copper River basin

Fierstein, J. E.

Flerstein \& Hildreth 1984 Pyroclastic deposits Novarupta [abs.] $V$ Fierstein \& Hilareth 1986 Novarupta ejecta [abs.]

Hildreth \& Fierstein 1986 Novarupta near vent ejecta [abs.] V H1ldreth \& others 1981 VTTS summary of strat \& petro of ejecta PG

Finch, R. H.

Finch 1935 Akutan volcano

$\mathrm{V}, \mathrm{H}$

Fitch, E.

Fitch 1927 Mineral waters of the U.S.

H

Fitterman, D. V.

Corwin \& Fitterman 1983 self potential Makushin geotherm area Ps Follett, A. B.

Benson \& Follett 1986 Photogrammetry study Mt. Wrangell

Forbes, R. B.

Dean \& others 1981 Remote sensing P1Igrim Springs

Forbes 1975 Geothermal energy \& wind power

Ps

Forbes 1976 Geothermal energy for Alaska

Forbes

1979 Geol, geoph assmt of geotherm pot P1Igrim HS

Gs, Ps

Forbes \& Biggar 1973 Ak geothermal resource potential R, HS

Forbes \& Kienle 1971 Augustine

Forbes \&ienle 1971 Petro pre 1912 pyroclast VTTS [abs] PG, Gs,V

Forbes \& others 1971 seismicity Augustine [abs.]

Forbes \& others 1975 Fission track age \& geotherm grad [abs.] HS

Forbes \& others 1975 Geophysical recon Pilgrim Springs

Forbes \& others 1975 Utilization geothermal rural Ak Fs,DP,Ef

Forbes \& others 1975 Utilization of Alaska thermal springs DP

Forbes \& others 1977 Fission track age \& geothermal gradient HS

Forbes \& others 1979 Geol, geoph assmt geothrm pot Pilgrim Gs,Ps

Forbes \& others 1979 Pilgrim springs hyarothermal system.

RM 
Foster \& others 1970 Geol Yukon-Tanana upland [abs.] Gr

Foster \& others 1973 Geology Yukon-Tanana upland Gr

Gedney \& others 1970 seismic refraction - Katmal Ps

Kienle Forbes 1974 AK volc studies Augustine

Kienle \& Forbes 1977 Augustine - Evolution of volcano

Kienle \& others 1970 Seism evidence pre 1912 tuff VTTS [abs.] Gr

Kienle \& others 1971 Microquake swarm Augustine [abs.] V,Ps

Motyka \& others 1980 Geochemistry Pilgrim thermal waters Fs, Fw

* Osterkamp \& others 1979 Conduct \& hydrol meas Pilgrim HS [abs] Ps Osterkamp \& others 1980 Recon study access power P1Igrim Ps,Gs,DP Ray \& others 1966 Petro \& geochem Mt Trident andesites [abs.] PG Swanson \& others 1980 Bedrock geol Pilgrim springs area Gs Turner \& Forbes 1980 Geol geophy stdy Pilgrim *,Gs, Ps, RM, Fs, Fw, HS Turner \& others 1979 Geol \& tect setting Pilgrim spr [abs.] Gs Turner \& others 1980 Geothermal resources Alaska Turner \& others 1980 Sum geol geophys invest Pilgrim spr Wilson \& Forbes 1969 Infrasonic waves \& volc erupt [abs.] Wilson \& Forbes 1969 Infrasonic waves Ak volc eruptions

R,FS RM

Ford, A. B.

Brew \& Ford 1985 Geol map Juneau, Taku, Atlin, Skag quad Gr

Foresman, J. B.

Foresman 1968 Photogeol \& geomorph Copper River basin Foresman 1970 kud volcanoes Copper River basin (thesis)

Foster, H. I.

Foster 1970 Recon geol map Tanacross Quad

Foster \& others 1970 Geol Yukon-Tanana upland [abs.]

Gr

Foster \& others 1973 Geology Yukon-Tanana upland

Gr

Foster \& others 1983 Geologic map Circle Q

Gr

Foster \& others 1983 Prelim geol map Circle Quad

Gr

Keith \& Foster 1979 Big Windy Creek HS

Keith \& others 1981 Chem \& isot data Big Windy Creek HS

Gr

FS

Menzie others 1983 Mineral assmt Circle Quad

Fs

Gr

Fournelle, J.

Fournelle \& Marsh 1986 Shishaldin lavas [abs.]

Fraser, G. D.

Drewes others 1961 Geol Unalaska \& adjacent shelf

Gr

Fraser \& Barnett 1959 Geol Delarof \& Andreanof Islands

Gr

Fraser \& Snyder 1959 Geol S Adak \& Ragalaska Islands

Gr

Snyder \& Fraser 1963 Pillowed lavas Unalaska

Gr

Fry, W. H.

Fry 1912 Mineral content volcanic ashes 
Funk, J. M.

Funk 1973 Iate Quat geol Cold Bay (thesis) Gr

Funk 1973 Late Quat hist Cold Bay [abs.]

Furst, J. I.

Furst 1968 Recon petrol Mt Wrangell caldera (thesis)

PG Gaffi, R. G.

Osterkamp \& others 1979 Conduct \& hydrol meas P1lgrim Hs [abs] Ps osterkamp others 1980 Recon study access power PIIgrim Ps, Gs, DP

Galloway, J. P.

Carter \& Galloway 1978 Geol map proposed gas IIne

Gr

Gassaway, J. S.

Eberlein others 1977 prelim geol map central Alaska Gr Gassaway \& Abramson 1977 Map \& table thermal springs cntr Ak R,Fs

Gates, 0 .

Gates others 1971 Geol Near Islands

Gr

Gedney, I.

Forbes \& others 1975 Geophysical recon Pilgrim springs

Gedney others 1970 Seismic refraction - Katmal

Ps

Ps

Gibson, D. E.

Buzzell \& Gibson 1986 Nome-Taylor Rd. cultural resources

C

Gilbert, F. P.

Andreasen \& others 1958 Aeromag Copper River basin

Pr

Gilbert, W. G.

Blodgett \& Gilbert 1983 Cheeneetnuk limestone Mc Grath Gr

Bundtzen \& Gilbert 1983 Geology upper Kuskokwim Gr

Dickey \& others 1982 Cenozolc seds \& Farewell fault Gr

Gilbert 1981 Geologic map Cheeneetnuk River area Gs

Gilbert \& Solle 1983 Prelim geol map Mc Grath A-3 Quad Gr

GIII, J. B.

Nye \& others 1983 Parental magmas Okmok: arc magmagen [abs.] PG 
AUTHOR

Glicken, $\mathrm{H}$.

Siebert \& others 1986 Debris avalanches Augustine [abs.]

Godwin, L, H.

Godwin \& others 1971 Classif of public land for geothermal R,DP

Gosink, J. P.

Gosink \& Osterkamp 1980 Prelim Invest hot water P1lgrim River HS Osterkamp \& others 1980 Recon study access power Pilgrim Ps,Gs,DP Turner \& others 1980 Sum geol geophys invest P1Igrim spr

RM

Gosink, T.

Gosink \& others 1986 Augustine ash [abs.]

Graback1, s. T.

Carey \& others 1983 Unalaska geotherm land, regs, \& environ DP

Grantz, A.

Andreasen \& others 1964 Geol inter mag \& grav Copper Rvr basn Grantz \& others 1962 Saline springs Copper River basin Winkler \& others 1981 Follo Valdez $Q$

Pr

Fs

Grewingk, $c$.

Grewingk 1850 Historic geology NW North America (Ger)

$\mathbf{V}, \mathbf{H}$

Griggs, R. F.

Griggs 1917 VTTS

Griggs 1918 Eruption of Ratmal

Griggs 1918 VTTS

Griggs 1918 VTTS mud flow

Griggs 1919 Character of Katmal eruption

Griggs 1919 Katmai \& VTS

Griggs 1921 VTTS

Griggs 1921 VTTS

Griggs 1922 VTTS

Griggs 1923 VTTS

Gr

Grim, P. J.

Berry \& others 1980 Thermal spring list U.S.

Grunder, A. I.

Hildreth \& Grunder 1980 VTTS comp \& 1sotope of ejecta [abs.] PG H1lareth \& others 1981 VTTS summary of strat \& petro of ejecta PG Johnson \& Grunder 1980 VTTS Tuff II Comp \& Isot ejecta [abs.] 
Grybeck, D. G.

Milier others 1972 prelim geol map Solomon \& SE Bendeleben $Q$ Gr Nelson \& Grbeck 1978 Arrigetch Peaks \& Igikpak plutons Gr

Turner \& others 1975 Rad dates Ak 1975 compliation Gr

Guffant1, $M$.

Brook \& others 1979 Hyarothermal systems <90 deg R, Fs Nathenson \& others 1983 Regional heat flow

Hagelbarger, $P$. R.

Sayre \& Hagelbarger 1918 Temps in VTrS H,HS

Haigler, L. B.

Godwin \& others 1971 classif of public land for geothermal R,DP Hamilton, T. D.

Hamilton 1973 snow \& lce during Katmal eruption [abs.]

Hanscom, J. T.

Osterkamp \& others 1979 conduct \& hydrol meas Pilgrim HS [abs] Ps

osterkamp \& others 1980 Recon study access power Pilgrim Ps,Gs,DP

Hansen, E.

Hansen \& others 1981 Mineral potential Ak Penin.

Gr

Haramura, H.

Ray \& others 1966 Petro \& geochem Mt Trident andesites [abs.] PG Harlow, D. H.

Forbes \& others 1971 selsmicity Augustine [abs.] Ps,V

Kienle others 1971 Microquake swarm Augustine [abs.] V,Ps

Harmon, $\mathrm{K}$.

Nehring \& others 1979 sulfate geotherm western U. S. R, RS Harmon, R. S.

Harmon \& others 1982 Isotopes from Augustine fumaroles Ff Harmon others 1984 Augustine chem \& isot character [abs.] PG Viglino others 1985 Isot evid magma comp in fum cond Augst $V, F f$ 
AUTHOR

Harrison, $W$.

Forbes others 1979 Geol, geoph assmt geothrm pot Pilgrim

Harrison \& Hawkins 1980 water \& heat flow Pilgrim HS

Gs, Ps

Hawkins \& Harrison 1979 Flow rate pligrim HS [abs.]

HS, DP

Turner \& others 1980 sum geol geophys invest Pilgrim spr

HS, DP

RM

Hartman, C. W.

Johnson \& Hartman 1969 Environmental atlas of Ak

Hartsock, J."K.

Detterman \& Hartsock 1966 Geol Iniskin-Tuxedni region

Gr

Hattor1, $\mathrm{K}$.

Okada \& others 1976 Hot springs village Port Moller

Hawkins, D. B.

Forbes \& others 1977 Fission track age \& geothermal gradient HS Forbes \& others 1979 Geol, geoph assmt geothrm pot Pilgrim Gs,Ps

Harrison \& Hawkins 1980 Water \& heat flow Pilgrim Hs

Hawkins \& Harrison 1979 Flow rate P1lgrim HS [abs.]

HS, DP

Hawkins \& Motyka 1985 stat chem anal H2O Copper River bsn Fs, Fw Motyka \& others 1986 Geochem isot org mud volc Copper R Fs,Ff, Fw Turner \& others 1980 sum geol geophys invest pilgrim spr

RM

Hedge, C. E.

Bunker \& others 1977 Prelim radio ages of rocks Kigluaik Mts Gr

Henderson, $\mathbf{J}$. R.

Andreasen \& others 1958 Aeromag Copper River basin

Henning, M. W.

Parmentier \& others 1983 Geol kydrotherm alter Makushin Gs,HA

Henning, R. A.

Henning others 1976 Alaska's volcanoes

Henning others 1981 Wrangell-st Elias Wilderness

Herreid, G.

Herreid 1966 Geol \& geochem Inmachuk River

Hickel, W. J.

Hickel 1972 National proposal for geothermal research

DP 
AUTHOR

Higbie, R. G.

Higble 1975 VTTS

Hildreth, $w$.

Elckelberger \& Hildreth 1986 Drilling in Katmal [abs.] V,Gs,Ps Fierstein \& Hildreth 1984 Pyroclastlc deposits Novarupta [abs.] V

Fierstein \&. Hildreth 1986 Novarupta ejecta [abs.]

H1ldreth 1980 Novarupta 1912 Petro of ejecta [abs.] PG

H11dreth 19811912 eruption VTTS [abs.] PG

Hildreth 1983 zoned eruption 1912 VTTS PG

Hildreth Fierstein 1986 Novarupta near vent ejecta [abs.] V

H1ldreth \& Grunder 1980 VTTS comp \& 1sotope of ejecta [abs.] PG

Hildreth \& others 1981 VTTS summary of strat \& petro of ejecta PG

Johnson \& H1ldreth 1980 VTTS Tuff I Empl, comp \& weld [abs.] V

Johnson \& Hildreth 1980 VTTS comp \& 1sot of ejecta [abs.] V

Rubenstone \& others 1985 Isot \& trace elem Katmal [abs.] PG

Hill, J. M.

* Lankford \& Hill 1979 strat \& depos envirn Dutch Harbor member Gr Hinckley, D. W.

Berg Hinckley 1963 Recon geol northern Baranof Is. Gr

Hoare, J. M.

Cady \& others 1955 Geology central Kuskokwim Gr

Decker \& Hoare 1982 Cretaceous Kuskokwim Group Cs

Detterman \& others 1976 Geol map by faults in Kenal \& Tyonek Q Gr

Hoare \& Coonrad 1959 Geol map Russian Mission Quad Gr

Patton \& Hoare 1968 Kaltag Fault W-C Ak

Gr

Hobbs, P. V.

Hobbs \& others 1977 Eruption of Augustine

stith \& others 1977 Nuee ardent Augustine volc

$\mathbf{v}$

Hoefs, J.

Harmon \& others 1984 Augustine chem \& 1sot character [abs.] PG

Holmes, C. E.

Holmes 1986 Archaelogical evaluation Makushin

C

Homan, F.

Homan 1972 Energy from the earth

$R, D P$ 
Hook, J.

Forbes others 1975 Geophysical recon Pilgrim Springs

Hopkins, D. M.

Hopkins 1963 Imuruk Iake Seward Penin

Gr

Hopkins \&opkins 1958 Seward Peninsula

Hopkins \& Taber 1962 stratigraphy Manley HS

Gr

Gs

Hopkins, J. P.

Hopkins \& Hopkins 1958 Seward Peninsula

Gr

House, I.

House \& others 1981 Selsmic gap near Unalaska

Gs

Hrallcka, A.

Hralicka 1945 Aleutian Is \& inhabitants

$\mathrm{C}, \mathrm{H}$

Hubbard, B. R.

Hubbard 1931 Geol Aniakchak \& Veniaminof [abs.]

Hubbard 1931 World inside a mountain

Hubbard 1935 Cradle of storms

Gr, H

$\mathrm{V}, \mathrm{H}$

$\mathrm{V}, \mathrm{H}$

Hudson, T. I.

Detterman \& others 1976 Geol map by faults in Renal \& Tyonek Q Gr Hudson 1977 Geol map Seward Penin

Hudson 1977 zoned granite stock Seward Penin

Hudson 1977 Zoned granite stock Seward Penin. (thesis)

Hudson $1979 \mathrm{Ig} \&$ meta rocks Serpentine HS area

$\mathbf{G r}$

Hudson \& Plafker 1978 Kiglualk \& Bendeleben faults

PG

Milier \& others 1972 Prelim geol map Solomon Sainsbury others 1970 Geol min dep geochem \&ad serpentine

Huebner, M. A.

i

Nehring others 1979 sulfate geotherm western U. S.

R,Fs

Hunt, s. $\mathbf{J}$.

Brew \& others 1984 Geologic map Peterbrg, Sumdum, P. Alex

Gr

Huot, J. P.

Rienle \& others 1978 Form. 2 maars behind volc arc [abs.] V Kienle \& others 1978 Formation 2 maars Ak Penin prelim results $V$ Self \& others 1978 Mechanisms deposits Ukinrek [abs.] Ps,Gs,V Self others 1980 Ukinrek Mars II deposits formation 
Huttrer, G. W.

Carey \& others 1983 Unalaska geotherm land, regs, \& environ DP Isselhardt others 1983 Geotherm resource model Makushin RM, HS Ikelman, J.A.

Berry \& others 1980 Thermal spring list U.S.

$\operatorname{Imm}$, T. A.

Imm 1986 Geol \& strat Mt Michelson quads

Ireland, R. R. W.

Collazzi \& Ireland 1986 Hydrology lower Ruskokwim basin

Isselhardt, C. F.

Isselhardt \& others 1983 Geotherm resource model Makushin RM,HS

Isselhardt \& others 1983 Temp grads Makushin geothermal area HS

Jackson, $\mathbf{s}$.

Jackson 1880 Alaska \& its missions $\quad \mathrm{H}, \mathrm{C}$

Jacob, K. H.

Boyd \& Jacob 1984 Seismlcity of Unalaska Pr

House \& others 1981 Seismlc gap near Unalaska Gs

Jacob \& Boyd 1985 Selsmic network on Unalaska Pr

Nakamura \& others 1977 Volc tectonlc stress orient Aleut \& Ak R,V

Jager, I.

Hildreth \& others 1981 VTTS summary of strat \& petro of ejecta PG Jaggar, T. A. Jr.

Jaggar 1908 Evolution Bogoslof Volcano

Jaggar 1908 Evolution of Bogoslof [abs.]

Jaggar 1908 Technical expedition to Aleutians

Jaggar 1927 Eruption of Mageik

Janik, C. J.

Motyka \& others 1986 Makushin well chem equilib *,Fw,Fs,Ff,HA,RM Jeffries, A.

Motyka \& others 1986 Geochem lsot org mud volc Copper R Fs,Ff,Fw 
AUTHOR

TOPIC

Jezek, P. A.

Scheldegger \& others 1977 Ash volc Aleut \& Kamchat arc [abs.] V

Johnson, D. A.

Johnson 1976 Zoned magma chamber Augustine [abs.]

k Johnson 1978 Magma mixing Augustine volcano (thesis)

Johnson 1978 Magma mixing Augustine volcano [abs.]

PG

PG

Johnson 1979 Volc gas studies Ak volcanoes

R, FE

Johnson 1979 Volcanism at Augustine

$\mathrm{V}, \mathrm{Gs}$

Johnson 1980 Volc contr Cl to stratosphere

$V, F f$

Johnson \& Detterman 1979 Revision of eruptive history Augustine $V$

Johnson \& Grunder 1980 VTTS Tuff II Comp \& isot ejecta [abs.]

Johnson \& Hildreth 1980 VTTS Tuff I Empl, comp \& weld [abs.]

Johnson \& Hildreth 1980 VTTS comp \& lsot of ejecta [abs.]

Johnson \& others 1977 Augustine Volc, evaluat hazards [abs.] V, Eg

Schmincke \& Johnson 1977 Pyroclastic flows Augustine [abs]

Viglino \& others 1985 Isot evid magma comp in fum cond Augst $V, F f$

Johnson, $\mathrm{K}$. $\mathrm{M}$.

W1lliams \& Johnson 1980 Map Tert \& Quat deposits Valdez $Q$

Gr

Johnson, P. R.

Johnson \& Hartman 1969 Environmental atlas of Ak

C

Jones, D.

Jones 1986 Coastal engineering - Makushin

Jones, D. I.

Jones \& others 1984 Terrane map Alaska

Gr

Jones, $\mathbf{S}$.

Emery \& Jones 1984 Hydrologic atlas Copper River basin

Juhle, R. W.

Juhle 1955 Illamna Volcano

Juhle \& Coulter 1955 Kt. Spurr eruption 1953

Muller \& others 1954 Volcanic activity Katmai

Williams \& others 1956 Mt Katmal \& VTT new interp 1912 eruptn

Gs

Kachadoorian, $\mathbf{R}$.

Sainsbury \& others $1968 \mathrm{SnO}_{2}$ Humbolt $\mathrm{Cr}$ Serpentine-Kougarok Gr Sainsbury \& others 1970 Geol min dep geochem \& rad serpentine $\mathrm{Gr}$ 
Kane, M. L.

Osterkamp \& others 1979 Conduct \& hydrol meas P1Igrim HS [abs] Ps Osterkamp \& others 1980 Recon study access power P1lgrim Ps,Gs,DP

Karl, S. M.

Brew \& others 1984 Geologic map Peterbrg, Sumaum, P. Alex

Gr

Kase, J: D.

Kase 1986 Trocadero soda springs

C

Katsui, $\mathbf{Y}$.

Katsui 1984 Okmok

Katsura, T.

Ray \& others 1966 Petro geochem Mt Trident andesites [abs.] PG Katz, F, J.

Martin \& Katz 1910 Geol \&in resources IIlamna \& Lake Clark $\mathrm{H}, \mathrm{Gr}$ Martin \& Katz 1912 Geol recon Illamna Region

Kay, R. W.

Conrad \& Kay 1984 Inclusions Adak Is-nature of primary magma PG

Kay \& Kay 1982 Aleut volc rock, primitive magmas [abs.]

Kay others 1982 Tectonic control of magmatism Aleut arc

Perfit \& others 1980 Model for fract in Aleut calc-alk suite

PG

PG

PG

Kay, S. M.

Kay \& Kay 1982 Aleut volc rock, primitive magmas [abs.]

PG

Kay \& others 1982 Tectonic control of magmatism Aleut arc

PG

Keith, T. E. C.

Foster \& others 1983 Geolog 1 c map circle $Q$

Foster others 1983 prelim geol map Circle quad

Keith 1984 Prelim obs fumaroles VTTS

Keith 1985 Hydrotherm alt Novarupta dome VTTS [abs.]

Ke1th 1986 Hydrothermal alteration Novarupta [abs.]

Keith Foster 1979 Big windy Creek HS

Keith \& others 1981 Chem I Isot data Big Windy creek HS

Thompson \& Ke1th $1984 \mathrm{Cl} F$ in waters VTTS [abs.]

HA

HA

$\mathrm{HA}, \mathrm{V}$

Fs

Fs

Fs

Keller, A. S.

Keller 1955 Geol Katmal [abs.]

Gr

Keller \& Relser 1959 Geol Katmal 
AUTHOR

TOPIC

Kennedy, G. C.

Rennedy \&aldron 1955 Geol Pavlof volcano

Kerr, F. A.

Kerr 1948 stikine \& Iskut River area BC, Canada

Gr

Keskinen, $M$.

Kodosky \& Keskinen 1986 Fumarole alt Augustine [abs.] FA, Ff,V

Kienle, J.

Barrett \& others 1977 Model of Augustine Volcano [abs.]

Berg \& Keinle 1966 Gravity meas Ratmai volc area

Berg \& others 1967 Crustal structure - Katmai

Davies \& Kienle 1986 Augustine eruption \& advice [abs.]

Forbes \& Kienle 1971 Augustine

Forbes \& Kienle 1971 Petro pre 1912 pyroclast VTS [abs]

Forbes \& others 1971 Seismicity Augustine [abs.]

Forbes \& others 1979 Geol, geoph assmt geothrm pot Pilgrim

Forbes \& others 1979 P1Igrim springs hydrothermal system

Johnson \& others 1977 Augustine Volc, evaluat
Kienle 1968 Gravity survey Katmal (thesis)

Kienle 1969 Gravity in the Aleutians [abs.]

Kienle 1969 Gravity traverse VTTS, Katmai [abs.]

Rienle 1970 Gravity traverse VTTS

Kienle 1972 Volc micro-quakes Augustine [abs.]

Klenle 1974 Alaskan volcano studies esp. Augustine

Kienle 1976 Seismic monitoring Pavlov

Kienle 1986 Augustine Volcano [abs.]

Kienle \& Forbes 1974 Ak volc studies Augustine

Kienle \& Forbes 1977 Augustine - Evolution of volcano

Kienle \& Lockhart 1979 selsm \& grav survey Pilgrim HS [abs.] Ps

Kienle \& Lokhart 1980 Gravity survey Pilgrim geotherm area Ps

Kienle \&ulpan 1975 Tide caused quakes at Augustine [abs.] Ps,V

Kienle \& Shaw 1977 Augustine erupt - initial phase 1976

Kienle Swanson 1980 Volcanic hazards Augustine

Kienle \& Swanson 1983 Volc E Aleut arc I Quat \& Holo cntrs

Kienle \& Swanson 1983 Volc E Aleut arc Quat \& Holo centers

Kienle Swanson 1985 Volc hazards Augustine 2nd ed.

Kienle \& others 1970 Seism evidence pre 1912 tuff VTTS [abs.]

Kienle \& others 1971 Microquake swarm Augustine [abs.]

V

$\mathrm{V}, \mathrm{Eg}$

$V$, PG

$\checkmark$, PG

$\mathrm{V}, \mathrm{Eg}$

Kienle \& others 1978 Form. 2 maars behind volc arc [abs.]

Kienle \& others 1978 Formation 2 maars Ak Penin prelim results

Rienle \& others 1979 Shallow magma at Augustine

Kienle \& others 1980 Ukinrek Maars 1977 eruption

Rienle \& others 1981 subd \& magma E Aleut arc [abs.]

Kienle \& others 1981 Volcanic centers Katmai [abs.]

Kienle * others 1983 Magmatism subduction E Aleutian arc

Kienle \& others 1986 Augustine \& tsunamis [abs.]

Lalla \& Kienle 1974 Infrared thermometry Augustine [abs.]

Lalla \& Kienle 1975 Microquakes, tremors at Pavlov [abs.]

$V$

V

R, PG

$\mathbf{V}, \mathbf{R}$

V, PG

$\mathrm{V}, \mathrm{HS}$

Ps, V 
Lalla \& Kienle 1976 Thermal studies Augustine [abs.] V,HS

Lalla \& Kienle 1978 Evolution seismicity Augustine [abs.] V,Ps

Lalla \& Rienle 1980 Problems volc selsmo Augustine [abs.] V,Ps

Lalla \& Rienle 1986 Sel's therm precursors erupt Augustine V,Ps,HS

Lockhart \& Kienle 1980 Selsm \& grav survey Pligrim spr KGRA Ps

Mauk \& Kienle 1973 Microquake Augustine earthtides Ps,V

Pearson \& Kienle 1978 Selsmic refr study Augustine [abs.] V,Ps

pulpan \& Kienle 1978 Selsmic \& volcanic risks, Alaska V,Eg

Riehle \& others 1981 Lahars Crescent River Iower cook Inlet v

Self \& others 1978 Mechanisms deposits Ukinrek [abs.] Ps,Gs,V

Self \& others 1980 Ukinrek Maars II deposits \& formation

siebert \& others 1986 Debris avalanches Augustine [abs.]

Stone \& Kienle 1975 Pavlov

Swanson \& Klenle 1982 Volc centers Katmal

Swanson \& others 1981 Geol \& petro Kaguyak Crater [abs.]

Turner \& others 1980 sum geol geophys invest Pilgrim spr

W11son \& Rienle 1976 Infrasonic signals Augustine volc [abs.]

King, J.

King 1909 Tanana Valley

H

Kirkwood, P.

Beebee \& Kirkwood 1979 Unalaska-geothermal prospects

C,EF

Kline, J. T.

Bundtzen \& Kline 1986 Coal, peat \& geotherm in Kuskokwim R,DP

Dickey others 1982 Cenozolc seds \& Farewell fault Gr

Forbes \& others 1979 Geol, geoph assmt geothrm pot Pilgrim Gs,Ps

Forbes \& others 1979 Pilgrim springs hydrothermal system RM

Kline 1980 Test drilling Pilgrim 1979 Er

Kline 1981 Surf geol Pilgrim vicinity

Kline others 1980 surf geol \& drilling Pilgrim HS Gs,Er

Osterkamp \& others 1980 Recon study access power P1lgrim Ps,Gs,DF

Turner \& others 1980 sum geol geophys invest P1lgrim spr RM

Knaebel, J.

Hansen \& others 1981 Mineral potential Ak Penin.

Gr

Knappen, R. S.

Knappen 1926 Geol \& min resources Anlakchak

Knappen 1933 Anlakchak \& Ventaminof volcanoes [abs.]

Gr

Knopf, A.

Knopf 1912 sitka mining district $\quad$ H, Gr

Koch, R. D.

Berg \& others 1978 Geol map Retchikan \& Prince Rupert Q Ak. Gr 
AUTHOR

TOPIC

KodoskY, I. G.

Kodosky \& Keskinen 1986 Fumarole alt Augustine [abs.]

Motyka \& others 1986 Augustine gas sampiling. [abs.]

$\mathrm{HA}, \mathrm{Ff}, \mathrm{V}$

Kosco, D. G.

Kosco 1981 Andesitic volcanism at Ratmai

Kosco 1981 Edgecumbe volc \& Katmal (thesis)

Kotani, $Y$.

Okada \& others 1976 Hot springs village Port Moller

Okada \& others 1979 Hot springs village Port Moller

Kowal1k, $z$.

Rienle others 1986 Augustine \& tsunamis [abs.]

Krause, $\mathbf{K}$.

Krause 1986 Power \& road corridor study Makushin

$\mathrm{Eg}, \mathrm{Ps}, \mathrm{DP}$

Kubota, s.

Berg \& others 1967 Crustal structure - Katmal

Kubota \& Berg 1967 Magma in Katmai range

Ps

$\mathrm{V}, \mathrm{Pr}$

Kulm, L. D.

Scheldegger \& Kulm 1973 Cyclic Aleut volc ash DSDP 178 [abs.] V

Kunza, J. F.

Economides others 1982 Reservoir eng analysis Pilgrim sprg

Kunza \& Iofgren 1983 Pligrim HS expl, drill, \& testing

KYle, P. R.

* Kienle \& others 1980 Ukinrek Maars 1977 eruption

V

Lachenbruch, A. H.

Iachenbruch \& others 1984 Geotherm Prudhoe Bay

Lawver \& others 1979 Regional heat flow Ak

Lahr, J. C.

Reeder \& others 1977 Seism Augustine volc [abs.] 
AUTHOR

TOPIC

Laird, J.

Foster \& others 1983 Geologic map Circle $Q$

Foster others 1983 Prelim geol map Circle Quad

Gr

Gr

Lalla, D. J.

Kienle others 1978 Form. 2 maars behind volc arc [abs.] V

Kienle others 1978 Formation 2 maars Ak Penin preiim results $V$ Kienle others 1979 Shallow magma at Augustine

Lalla 1987 Seismo \& thermal studies Augustine (thesis) V,Ps,HS

Lalla \& Kenle 1974 Infrared thermometry Augustine [abs.] V,HS

Lalla Kienle 1975 Microquakes, tremors at Pavlov [abs.] Ps,V

Ialla Kienle 1976 Thermal studies Augustine [abs.] V,HS

Lalla " Kienle 1978 Evolution seismicity Augustine [abs.] V,Ps

Lalla \&ienle 1980 Problems volc selsmo Augustine [abs.] V,Ps

Ialla \& Kienle 1986 Seis therm precursors erupt Augustine V,Ps, HS

Langmuir, . C. $\mathrm{H}$.

Rubenstone \& others 1985 Isot \& trace elem Katma1 [abs.] PG

- Langsdorff, G. H. von

Langsdorff 1814 Voyages $1803-1807$

H

Lankford, S. M.

Iankford \& H111 1979 strat \& depos envirn Dutch Harbor member Gr

Lanphere, M. A.

Ioney \& others 1967 Radio ages \& fault movements $N$ SE Ak Gr Miller \& others 1966 Prelim plutonic belt $W$ cent Ak Gr Reed Lanphere 1972 Geol map Ak-Aleut batholith $\mathrm{K} / \mathrm{Ar}$ ages Gr Reed \& Lanphere 1973 Ak-Aleut batholith, geochron \& chem Gr Reed \& Lanphere 1973 Plutonic rocks Ak-Aleut batholith

Gr

Larsen, $\mathbf{M}$.

Motyka \& others 1985 Geol geoc geophys Akutan *,Gs,Fs,Ps,RM,Ff,DP

Lathram, E. H.

Beikman \&athram 1975 Prelim geol map $N$ Ak

Gr

Latten, J. $\mathrm{H}$.

Simkin \& others 1981 volcanoes of the world

$\mathbf{V}, \mathbf{R}$

Lawrence, J.R.

Perfit \& others 1980 Model for fract in Aleut calc-alk suite PG 
AUTHOR

Iawton, N. 0 .

Iawton 1909 Makushin sulfur deposits

Lawver, I. A.

Lawver \& others 1979 Regional heat flow Ak

HS

Iecompte, J. R.

Lecompte 1981 Prelim map Landsat Ugashik \&arluk $Q$

Gr

Lebida, R. C.

Baker \& others 1977 Geotherm springs-salmon hatchery site R,DP,Fs

Leeman, P. P.

Richter \& others 1984 Shield volc Wrangell Mts

$-\quad$ Leonard, L. E.

Forbes \& others 1975 Ut1l1zation geothermal rural Ak Fs,DP,Ef Forbes \& others 1975 Utilization of Alaska thermal springs DP Leonard 1975 Geothermal energy

Lewis, R. Q.

$\Rightarrow \quad$ Coats \& others 1961 Geol recon Kiska Island

Lewis \& others 1960 Geol Rat Islands, Aleutians

Lian, E. B.

Church \& others 1970 copper River basin strat correl section

Iimke, A. J.

Iimke \& Beget 1986 Pyroclastic flows Augustine [abs.]

IIss, S. A.

Hotyka \& others 1981 Assmt thermal spring Aleutian arc R,Fs,Ff, Gr Motyka \& others 1983 Geothermal resources of Alaska R,Fs,Ff,Fw Motyka \& others 1986 Makushin well chem equilib *,Fw,Fs,Ff, HA, RM

Lockhart, A. B.

Klenle \& Lockhart 1979 Seism \& grav survey P1lgrim HS [abs.] Ps Kienle \& Iockhart 1980 Gravity survey Pilgrim geotherm area Ps Lockhart 1981 Gravity survey central seward Penin. 
AUTHOR

TOPIC

Turner \& others 1980 Geothermal resources Alaska

Wescott \& others 1980 Resis survey Pilgrim spr area

Lofgren, B. E.

Economides \& others 1982 Reservoir eng analysis Pilgrim Sprg Er Kunza \& Lofgren 1983 Pilgrim HS expl, drill, \& testing Lofgren 1983 Geotherm devel Pilgrim springs

Loney, R. A.

Brew \& others 1965 Eruptive history Mt. Edgecumbe [abs.] V Brew o others 1969 Recon geol Mt Edgecumbe Loney \& others 1963 Geol Freshwater Bay Chichagof Is Loney \& others 1963 Recon geol map Chichagof \& NW Baranof Is Gr Ioney \& others 1964 Recon geol map Baranof \& Kruzof Is Loney \& others 1967 Radio ages \& fault movements N SE AK Gr Loney \& others 1975 Recon geol Chichagof, Baranof \& Rruzof Is Gr

Long, G. A.

Spencer \& others 1982 Anal geothrm res devel Unalaska EF,DP Long, w. E.

Long 1986 Glacial hazard Makushin

Longenkamp, $D$.

Longenkamp \& others 1974 Elec resist survey Pilgrim Springs Ps

Lorenz, V.

Kienle \& others 1980 Ukinrek Maars 1977 eruption

Lorenz 1982 Eruption Ukinrek Maars

Lovering, T. S.

Lovering 1955 Alteration near halogen-sulfur fumarole [abs.] HA Lovering 1957 Halogen-acid alteration VTTS $\mathrm{HA}, \mathrm{Ff}$

Luedke, R. G.

Smith \& others 1978 Data \& therm energy est young ig sys US R, HS Lyle, พ. M.

Lyle 1973 Geol \& mineral evaluation Aniakchak $R$ drainage Gr Lyle \& Dobey 1974 Geol evaluation Herendeen Bay area

Mabey, D. R.

Brook others 1979 Hydrothermal systems $<90$ deg R, Fs Mariner \& others 1978 Data for hydrothermal systems $>=90$ R,Fs 
AUTHOR

TOPIC

MacGregor, A. G.

MacGregor 1952 Eruptive mechanisms VTTS V V

Mackeith, P.

Benson \& others 1985 Glacio-volcano studies Mt. Wrangell v

Motyka \& others 1978 Increased heat Mt Wrangell [abs.] HS

Motyka \& others 1980 Mt Wrangell glac meas heat flow [abs.] V,HS .

Mackevett, E. M. Jr.

MacKevett 1976 Geol map McCarthy $Q$

Mackevett 1978 Geol map McCarthy Q

Winkler \& others 1981 Follo Valdez Q

Gr

Gr

Gr

Maddren, A. G.

Maddren 1919 Sulfur on Unalaska \& Akun Is \& Stepovak Bay H,Gr March, G. D.

March 1986 Avalanche hazards- Makushin

Marinelli, G.

Bordet \& others 1963 Katmai

Mariner, R. H.

Brook \& others 1979 Hydrothermal systems <90 deg

Mariner \& others 1978 Data for hydrothermal systems $>=90$

Nehring \& others 1979 Sulfate geotherm western U. S.

Reed \& others 1983 Data low temp geothermal systems US

R,Fs

R,Fs

$R, F s$

HS, R, FS

Markle, D. R.

Economides \& others 1981 Unalaska geothermal development DP

Markle 1979 Geotherm Ak site data base \& devel status R,Fs,Gr,C Markle 1979 Geothermal energy devel Pilgrim HS DP

Reeder \& others 1980 Geothermal implementation plan DP

Reeder \& others 1982 Econ \& eng geoth develop Makushin EF,Eg,DP

Marsh, B. D.

Brophy \& Marsh 1984 Petro \& geochem Cold Bay volc [abs.]

PG

Coats \& Marsh 1984 Recon geol \& petrol N Tanaga [abs.]

Fournelle \& Marsh 1986 Shishaldin lavas [abs.]

Marsh 1974 Aleutian arc magmatism (thesis)

Marsh 1980 Geol \& petrol N Atka Is [abs.]

Marsh 1982 Aleutians - orogenic andesites

Myers \& Marsh 1981 Geol \& petrogen Edgecumbe volcanics 
AUTHOR

Myers others 1984 Assim crust by basalt magma Edgecumbe PG Myers \& others 1986 Isot var Adak \& Atka volc plumb V,PG,Gr

Marsha11, B. V.

Lachenbruch \& others 1984 Geotherm Prudhoe Bay

Martin, G. C.

Martin 1913 Eruption Katma1

$\mathrm{V}, \mathrm{H}$

Martin 1917 Mineral resources of Ak.

$\mathrm{H}, \mathrm{Gr}$

Martin \& Katz 1910 Geol min resources Iliamna \& Lake Clark $\mathrm{H}, \mathrm{Gr}$ Martin * Katz 1912 Geol recon Iliamna Region

$\mathrm{H}, \mathrm{Gr}$

Mathewson, D. E.

Simons \& Mathewson 1955 Geol Great sitkin Is

Gr

Matlick, J.S.

Isselhardt others 1983 Geotherm resource model Makushin RM, HS Isselhardt \& others 1983 Temp grads Makushin geothermal area HS Matlick \& Parmentier $1983 \mathrm{Hg}$ soll survey Makushin : GC,Fs, Ff

Matsumoto, $\mathrm{H}$.

Ray others 1966 Petro \& geochem Mt Trident andesites [abs.] PG

Matteson, $\mathbf{c}$.

Gedney \& others 1970 Selsmic refraction - Katmal Ps

Matumoto, T.

Matumoto 1971 seism body waves Katmal \& molten chmbr [abs.] Pr,V Matumoto \& Molnar 1967 Shadow effect S waves Katmal [abs.] Pr,V. Matumoto \& Ward 1967 Microquake study Katmal

Sbar \& Matumoto 1972 Refraction VTTS

Ward \& Matumoto 1967 Sum volc \& selsmic activity Katmal : V,Pr

Mauk, F. J.

Mauk \& Rienle 1973 Microquake Augustine earthtides Ps,V

Maurer, M. A.

Carrick \& Maurer 1986 Hydrology - Makushin . Gs

Mayaoka, R. T.

Dover \& Mayaoka 1985 Rocks Ray Mts, Tanana \& Bettles $Q$ Gr 
AUTHOR

TOPIC

Maynard, D.

Swanson \& others 1980 Bedrock geol Pilgrim springs area

Turner \& others 1979 Geol \& tect setting Pilgrim spr [abs.]

Mcclelland, I.

Simkin \& others 1981 Volcanoes of the World

McCoy, G. A.

Barnes \& McCoy 1979 Mantle-derived CO2 in 2 phreatic expl Fs,Ff,V MoFarlane, R. M.

Kline \& others 1980 surf geol \& drilling Pilgrim HS Gs, Er MoNutt, S. R.

McNutt 1983 Activity Pavlov Shumagin gap? [abs.]

McNutt 1984 Eruption \& stress Paviov [abs.]

McNutt \& Beavan 1981 Quakes at Pavlov earth tides

McNutt \& Beavan 1984 Pavlov sea level \& aseismic slip [abs.]

McNutt \& Mori 1983 B type quakes Pavlov [abs.]

Meaker, P.

Meaker 1908 Tanana Valley

$\mathrm{H}, \mathrm{C}$

Melgs, A. J.

Meigs 1986 structural evol Saderochit Mts.

Gr

Mendenhall, พ. c.

Mendenhall 1903 Mineral resources Mt Wrangell district

Mendenhall 1905 Geology central Copper River region

$\mathrm{H}, \mathrm{Gr}$

$\mathrm{H}, \mathrm{Gr}$

Menyaylov, I. V.

Menyaylov 1969 Comparison Bezymyany \& Ratmai (Rus) V,Ff

Menzie, พ. D.

Foster \& others 1983 Geologic map Circle Q

Foster \& others 1983 Prelin geol map Circle Quad

Menzie \& others 1983 Mineral assmt circle Quad

Merriam, C. H.

Merriam 1901 Birth of Bogoslof

$\mathbf{H}, \mathbf{V}$ 
Merrill, G. P.

Merrill 1885 Hornblende andesites from Bogosloff

H, Gs, PG

Merriman, C. H.

Merriman 1910 Bogoslof new volcano

V

Mertie, J. B. Jr.

Mertle 1930 Geology Eagle-circle district Gr

Mertie 1932 Yukon Tanana region Gr

Mertie 1934 Mineral deposits Rampart \& Hot Springs district $G r$

Metzner, R. C.

Metzner 1975 Magnetotelluric invest. Augustine (thesis) Ps,v

Miller, J. W.

Yount \& others 1985 New Holo vent Port Moller \& stepovak Bay Q V

Miller, R. J.

Winkler \& others 1981 Folio Valdez $Q$

Gr

Miller, T. P.

Barnes Miller 1974 Geotherm studies in Alaska [abs.] R, Fs

Detterman \& others 1979 Geol map Chignik \& Sutwik Is $Q$ Gr

Detterman \& others 1981 Geol map Chignik \& Sutwik Is $Q$ Gr

Detterman \& others 1981 Quat geol map Chignik \& Sutwik Is $Q$ Gr

Detterman \& others 1985 Geol map Ugash1k \& $W$ Karluk $Q$ Gr

Detterman \& others 1986 Quat map Ugashik-Bristol Bay-Karluk Q Gr

Miller 1970 petro plutonic rocks w central Ak PG

Milier 1971 petro plutonic rocks $W$ cent Ak (thesis) PG

Miller $1972 \mathrm{~K}$ rlch intrusive rocks $\mathrm{W}$ Ak PG

Milier 1973 Distribution \& chem analysis thermal springs Ak R,Fs

Miller 1976 Augustine volcano

Miller 1978 Alrfall pumice Aniakchak.

Miller 19842 stage volcanism Ugashik-Peulik [abs.] PG

Miller \& Barnes 1974 Geotherm devel Ak [abs.] DP, Gr,V

Miller \& Barnes 1976 Geotherm develop Ak summary $\quad$ DP, Gr,V

Miller \& Smith 1975 Ak geothermal study $R$

Miller \& Smith 1975 Ash flows Ak Penin prelim rpt [abs.] V, Gr

Miller \& Smith 19762 caldera forming eruptions Umnak $\quad V$

Miller Smith 1976 Ash flows Wrangell volcano $\quad$ S V

M1ller \& Smith 1976 New volcanoes Aleutian arc $\quad v$

Miller \& Smith 1977 Mobile ash flows Aniakchak \& Fsher calds V

Miller smith 1983 Calderas E Aleutian arc [abs.] Gr

Miller others 1966 Prelim plutonic belt $W$ cent Ak Gr

Miller others 1972 prelim geol map Solomon \& SE Bendeleben $Q$ Gr

Miller \& others 1975 Geol \& chem hot springs $W$ cent Ak R,Fs 
AUTHOR

TOPIC

Patton \& M1ler 1966 Regional geol map Hughes $Q$

Gr

Patton \& Miller 1970 Prelim geol invest Ranuti.

Gr

Patton \& others 1968 Reg geol map Shungnak \& Ambler River Q

Patton \& others 1978 Geol map Melozitna Q

Richter \& others 1979 Geol map Gulkana $A-2$ Q

Yount \& others 1985 Eruption Mt Veniaminof

Gr

Gr

Gr

V

Mittempergher, $\mathbf{H}$.

Bordet \& others 1963 Katmai

$\mathbf{V}$

Moffit, F. H.

Moffit 1905 Fairhaven gold placers Seward Penin

$\mathbf{H}, \mathbf{G r}$

Mo11, E. J.

Silberman \& others 1978 Age of rocks Ruby, Medfra \& adj $Q$

Gr Molnar, P.

Matumoto \& Molnar 1967 Shadow effect S waves Katmai [abs.] Pr,V

Monger, J. W. H.

Monger \& Berg 1985 Terrane map SE Ak. \& W. Can.

Monroe, R. M.

Nathenson \& others 1983 Regional heat flow

R, HS

Moorbath, $\mathbf{s .}$

Harmon \& others 1984 Augustine chem \& isot character [abs.]

PG

Moore, P.

Wescott \& others 1986 Geophysical surveys Mt. Spurr

Wescott \& others 1986 Ice thickness Mt. Spurr summit

Ps, R

Ps

Moorman, K. A.

Motyka \& Moorman 1980 Assmt thermal spring S SE Ak [abs.] R,Fs

Motyka \& Moorman 1981 Recon thermal spr Aleutian arc R,Fs, Ff

Motyka \& Moorman 1987 Geotherm resourcers SE Ak

Motyka \& others 1980 Assmt therm spr S SE AK

R,Fs, FW

Motyka \& others 1980 Geochemistry P11grim thermal waters Fs, Fw

Motyka \& others 1981 Assmt thermal spring Aleutian arc R,Fs,Ff, Gr

Motyka \& others 1982 Fluid geochem Hot Springs Akutan Fs, Ff

Motyka others 1982 Fluid geochemistry Makushin area Fs, Ff

Motyka \& others 1983 Fluid investigations Makushin area Fs, Ff

Motyka \& others 1983 Geothermal resources of Alaska R,Fs,Ff, Fw

Motyka \& others 1985 Geol geoc geophys Akutan *,Gs,Fs,Ps,RM,Ff,DP

Turner \& others 1980 sum geol geophys invest Pilgrim spr RM 
AUTHOR

Morgan, L.

Korgan 1980 Aleutlans

C

Mori, J.

MoNutt \& Mor1 1983 B type quakes Paviov [abs.]

v

Morris, c. $w$.

Economides others 1985 Eval Makushin geothermal reservoir Er

Morris, D.

Morr1s 1985 Katmal Park draft management plan

$C, D P$

Morrison, $\mathrm{P}$.

Nava Morrison 1974 Note on hot springs interior Ak R,Fs

Morrison-knudson Co., Inc.

Morrison-Knuason Co. 1981 Geotherm potential Aleut Unalaska

$\mathbf{R}$

Moses, T. H. Jr.

Lachenbruch \& others 1984 Geotherm Prudhoe Bay

HS

Lawver others 1979 Regional heat flow Ak

Motyka, R. J.

Benson Motyka 1978 Glac-volc Interaction Mt. Wrangell

Benson \& others 1985 Glacio-volcano studies Mt. Wrangell

Harmon \& others 1982 Isotopes from Augustine fumaroles

Hawkins Hotyka 1985 stat \& chem anal H2O Copper River bsn FE, FW

Isselhardt others 1983 Geotherm resource model Makushin RM, HS

Kienle others 1978 Form. 2 maars behind volc arc [abs.] V

Kienle others 1978 Formation 2 maars Ak Penin prelin results $V$

Kienle \& others 1980 Ukinrek Maars 1977 eruption

Motyka 1977 Katmai caldera geothermal activity

Motyka 1978 surveillance Katmal caldera \& crater lake

Motyka 1982 Eluid geochem Makushin A Akutan geotherm area.

$\begin{array}{llll}\text { Motyka } & 1982 \text { Fluid geochemistry of Makushin } & \text { Fs, Ff } \\ \text { Motyka } & 1982 \text { High temp hydrotherm Aleutian arc [abs.] R, Fs, Ff }\end{array}$

Motyka 1983 Geochem Isotope study water gas Makushin Fs,Ff

Motyka $1983 \mathrm{High}$ temp hydrothermal resources Aleut arc R,Fs, Ff

Motyka 1983 Thermal activity Ht Wrangell (thesis) V,HS, Ff

Motyka 1984 Chem of water \& gas ut wrangell [abs.] Ff

Motyka \& Benson 1982 Flucts in heat flow Mt Wrangell [abs.] $v$, HS Motyka Moorman 1980 Assmt thermal spring S SE Ak [abs.] R,Fs Motyka Moorman 1981 Recon thermal spr Aleutian arc R,Fs, Ff Motyka Moorman 1987 Geotherm resourcers SE Ak R, Fs, FW Motyka \& Queen 2984 Makushin fluids samps \& well 109 Fs,Ff,FW,PG 
Motyka \& others 1977 Glac-volc investigations Katmal [abs.] v Motyka others 1978 Increased heat Mt Wrangell [abs.] HS Motyka \& others 1980 Assmt therm spr S SE Ak R,Fs Motyka \& others 1980 Geochemistry Pilgrim thermal waters Fs, Fw Motyka others 1980 Mt Wrangell glac meas heat flow [abs.] V, HS Motyka \& others 1981 Assmt thermal spring Aleutian arc R,Fs,Ff, Gr Motyka \& others 1982 Fluid geochem Hot Springs Akutan

Motyka \& others 1982 Fluid geochemistry Makushin area

Motyka \& others 1983 Fluid Investigations Makushin area

Motyka \& others 1983 cer

Hotha Motyka others 1985 Geol geoc geophys Akutan *, Gs, Fs, Ps, RM, Ff, DP Motyka \& others 1986 Augustine gas sampling [abs.] Ff Motyka \& others 1986 Geochem isot org mud volc Copper R Fs,Ff, Fw Motyka \& others 1986 Makushin well chem equilib *,Fw,Fs,Ff, HA, RM Nye others 1984 Geol map Makushin geothermal area Poreda \& others 1981 He lsot vars Ak-Aleut arc [abs.] R,Fs,Ff Queen \& Motyka 1984 Changes in Makushin geoth system [abs.] HA Reeder \& others 1980 Ak. geothermal program

Swanson \& others 1983 Petro Makushin volc [abs.]

FE, Ff

Fs, Ff

Turner \& others 1980 sum geol geophys invest Pilgrim spr

Turner \& others $1983 \mathrm{sum}$, Viglino \& Viglino \& others 1985 Isot evid magma comp in fum cond Augst $V, F f$ Wescott \& others $1982 \mathrm{He}$ \& Hg survey parts Unalaska

GC Wescott \& others 1985 Prelim rept gthrml invest Mt spurr Gs,Ps,GC

Muffler, I. J. P.

Brew \& others 1965 Eruptive history Mt. Edgecumbe [abs.]

Brew others 1969 Recon geol Mt Edgecumbe

Brook \& others 1979 Hydrothermal systems <90 deg

Godwin \& others 1971 Classif of public land for geothermal

Loney \& others 1964 Recon geol map Baranof \& Rruzof Is

Loney \& others 1975 Recon geol Chichagof, Baranof \& Kruzof

Muffier 1973 Geothermal resources

Muffler 1979 Assmt geothermal resources U. S.

RM

Muller, E. H.

Muller others 1954 Volcanic activity Katmal

Munroe, R. J.

Iachenbruch \& others 1984 Geotherm Prudhoe Bay

HS

Murphy, J. M.

Robinson \& others 1984 Bdrck geol Chuilnuk \& Riokluk Mts [abs] Gr Robinson \& others 1984 Geologic map sleetmute B-5 Q

Murty, T. S.

Kienle \& others 1986 Augustine \& tsunamis [abs.] 
Myers, J. D.

Myers 1978 Petro \& petrogenesis Edgecumbe volc [abs.] PG Myers 1979 Geol, petro IEdgecumbe: trnsfrm fault volc (thesis) PG Myers \& Marsh 1981 Geol \& petrogen Edgecumbe volcanics PG Myers \& others 1984 Assim crust by basalt magma Edgecumbe PG Myers \& others 1986 Isot var Adak \& Atka volc plumb V,PG,Gr

Naeser, D. W.

Forbes \& others 1977 Fission track age \& geothermal gradient HS Nakamura, $K$.

Nakamura \& others 1977 Volc tectonlc stress orlent Aleut \& Ak R,V Nathenson, $M$.

Nathenson others 1983 Regional heat flow R, HS Nava, J.A.

Nava 1975 Note on hot springs SE Ak

Nava \&orrison 1974 Note on hot springs interior Ak

Neal, R. J.

Neal \& Swanson 1983 Petro geochem Westdahl \& Pogromnl [abs.] PG Nehring, N. L.

Harmon \& others 1982 Isotopes from Augustine fumaroles Ff

Nehring \& others 1979 Sulfate geotherm western U. S.

VIglino \& others 1985 Isot evid magma comp in fum cond Augst $V, F f$ Nelson, J. S.

Longenkamp \& others 1974 Elec resist survey Pligrim Springs Ps Nelson, S. W.

Nelson \& Grybeck 1978 Arrigetch Peaks \& Igikpak plutons Gr Nelson, พ. H.

Coats \& others 1961 Geol recon Kiska Island

Lewis \& others 1960 Geol Rat Islands, Aleutians

Nelson 1959 Geol Segula, Davidov, Khvostov Islands

Newhal1, C. G.

simkin \& others 1981 Volcanoes of the World 
AUTHOR

TOPIC

Nicholas, T. J.

Carey \& others 1983 Unalaska geotherm land, regs, \& environ DP

Nichols, C. R.

Nichols \& Reeder 1983 Ak geothermal \& hydrotherm development R,DP

Nichols, D. R.

Ferrians \& Nichols 1965 Copper River basin

Ferrians \& others 1958 Pleist volc mudflow Copper River basin

Ferrians \& others 1983 Copper River basin

Nichols \& Yehle 1961 Anal gas \&ater copper River basin

Nichols \& Yehle 1961 Kud volc Copper River basin

Nichols \& Yehle 1969 Eng geol map SE Copper River basin

V

Yehle \& Nichols 1980 Recon map Chetaslina debris flow Copper $R$

Gr

Fs

Fs

Gs

Ninkovich, D.

Scheldegger \& others 1977 Ash volc Aleut \& Ramchat arc [abs.] V Nye, C. J.

Nye 1982 Wrangell volcs \& microplate accretion [abs.]

Nye 1983 Petro \& geochem Okmok \& Wrangell volcs (thesis) PG,V Nye 1986 Volcanic hazards, Makushin

Nye \& Reid 1986 Geochem pri lava Okmok Volc: arc magmagenesis PG Nye \&wanson 1986 Chem strat magma plumb Makushin [abs] V,Gs,PG Nye \& Swanson 1987 Makushin magma chamber

Nye \& Turner 1986 Geology \& geochemistry spurr [abs.] $P G, G s, V$ Nye \& others 1984 . Geol map Makushin geothermal area Nye \& others 1986 Petro geochem Quat volc Makushin [abs.] PG *, V, Gs, PG Robinson \& others 1986 Rocks from sleetmute, Russian Mission Q PG Swanson \& others 1983 Petro Makushin volc [abs.] PG Swanson \& others 1986 Magmatic evolution Augustine [abs.] PG,V Turner \& Nye 1986 Geochronology Mt. Spurr

Turner \& others 1983 Sum, eval gthrm exp Copper R bsn Gs, Ps, Fs, RM Turner \& others 1986 kt. Spurr geothermal project $R, G s, V$ Wescott \& others 1985 Prelim rept gthrml invest Mt Spurr Gs,Ps,Gc

Odum, J. K.

Yehle \& others 1985 Geol frm drilling in copper R. basin

Gr Ogle, w.

Ogle 1976 Ak. hot spring site for small binary plant R,DP,Fs 
Okada, A.

Okada okada 1974 Hot springs village Port Holler

Okada \& Okada 1980 Hot springs site Port Moller

Okada \& others 1976 Hot springs village Port Moller

Okada \& others 1979 Hot springs village Port Moller

C

C

C

C

Okada, H.

Okada \& Okada 1974 Hot springs village Port Moller

Okada \& Okada 1980 Hot springs site Port Moller

Okada \& others 1976 Hot springs village Port Moller

okada others 1979 Hot springs village port Moller

C

C

C

C

Okimura,; $\mathrm{H}$.

Okimura 1930 Eruption Katmal

$\mathbf{V}, \mathbf{H}$

Olds, B.

Henning \& others 1976 Alaska's-volcanoes

Henning \& others 1981 Wrangell-st Ellas Wilderness

$\mathbf{V}, \mathbf{R}$

Osterkamp, T. E.

Forbes \& others 1979 Geol, geoph assmt geothrm pot P11grim Gs,Ps Forbes \& others 1979 P1Igrim springs hydrothermal system RM Gosink \& Osterkamp 1980 Prelim invest hot water P1Igrim River HS Osterkamp \& others 1979 Conduct \& hydrol meas Pilgrim HS [abs] Ps Osterkamp \& others 1980 Recon study access power P1Igrim Ps,Gs,DP Turner \& others 1980 Sum geol geophys invest Pilgrim spr RM

Ovenshine, A. T.

Brew \& others 1984 Geologic map Peterbrg, sumdum, P. Alex Gr Eberlein \& others 1983 Geol map Cralg $Q$

Packer, D. R.

stone \& Packer 1972 Paleomag VTTS [abs.]

Page, R. A.

Page \& others 1982 seism Spurr, Redoubt, \& Illamna [abs.]

Palache, $c$.

Palache 1904 Geol Chlchagof Cove, stepovak Bay

Parmentler, P. P.

Isselhardt \& others 1983 Geotherm resource model Makushin RM, HS

Isselhardt \& others 1983 Temp grads Makushin geothermal area HS 
AUTHOR

TOPIC

Matlick \& Parmentier $1983 \mathrm{Hg}$ soll survey Makushin GC,Fs,Ff Parmentier \& others 1983 Geol hydrotherm alter Makushin Gs, HA

Patton, พ. พ. Jr.

Brosge \& Patton 1982 Bedrock geol maps Dalton Hwy

Miller others 1966 Prelim plutonic belt W cent Ak

Miller \& others 1975 Geol \& chem hot springs W cent Ak

Patton 1973 Recon geology N Yukon-Koyukuk

Patton \& Hoare 1968 Kaltag Fault W-C Ak

Patton \& Miller 1966 Regional geol map Hughes Q

Patton \& Miller 1970 Prelim geol invest Ranuti

Patton \& others 1968 Reg geol map Shungnak \& Ambler River Q

Patton \& others 1978 Geol map Melozitna Q

Silberman \& others 1978 Age of rocks Ruby, Medfra \& adj Q

Gr

R, Fs

Gr

Gr

Gr

Gr

Gr

Gr

Gr

Pavia, E. A.

Pavia 1986 structure strat Okpilak batholith area

Gr

Peace, J.

Wescott \& others 1980 Resis survey P1lgrim spr area

Peale, A. C.

Peale 1886 Mineral springs of US $\mathrm{H}, \mathrm{R}$

Pearson, C. F.

Kienle \& others 1979 Shallow magma at Augustine

Pearson 1977 Seismic refr Augustine (thesis)

Pearson \& Kienle 1978 Seismic refr study Augustine [abs.]

$\mathrm{V}, \mathrm{Ps}$

$\mathrm{V}, \mathrm{Ps}$

Pearson, K. S.

Barnwell \& Pearson 1984 Ak resource inventory

DP

Perfit, M. R.

Perfit \& others 1980 Model for fract in Aleut calc-alk suite Perrey, A.

Perrey 1866 Quakes \& volcanism Aleutians \& Ak Penin (Fr)

Pessell, G. H.

Brosge \& Pessel 1977 Prelim recon geol map Survey Pass Q Petrov, I.

Petrov 1884 Alaska population \& resources

Ps 
Petzinger, B.

Motyka others 1985 Geol geoc geophys Akutan *,Gs, Fs, Ps, RM, Ff, DP Wescott others 1981 Geophys survey summer Bay Ps Wescott others 1982 Geophys survey Hot Springs Akutan Is Ps Wescott others $1982 \mathrm{He} \& \mathrm{Hg}$ survey parts Unalaska GC

Pewe, T. I.

Pewe 1975 Quaternary geology of Ak

Plafker, $G$.

Detterman \& others 1976 Geol map by faults in Kenal \& Tyonek Q Gr Jones \& others 1984 Terrane map Alaska Gr

Pomeroy, J. S.

Loney \& others 1963 Recon geol map Chichagof \& NW Baranof Is Gr Loney \& others 1964 Recon geol map Baranof \& Kruzof Is

Poreda, R. J.

Motyka \& others 1982 Fluid geochem Hot Springs Akutan

Fs, Ff

Motyka \& others 1982 Fluld geochemistry Makushin area

Motyka \& others 1983 Fluid investigations Makushin area Fs, Ff

Motyka \& others 1985 Geol geoc geophys Akutan *,Gs, Fs, Ps, RM, Ff, DP

Motyka o others 1986 Geochem isot org mud volc copper R Fs,Ff, Fw

Motyka \& others 1986 Makushin well chem equilib *,Fw,Fs,Ff, HA, RM

Poreda \& others 1981 He isot vars Ak-Aleut arc [abs.] R,Fs,Ff

Powers, H. A.

Coats \& others 1961 Geol recon Kiska Island

Gr

Gates \& Others 1971 Geol Near Islands

Lewis \& others 1960 Geol Rat Islands, Aleutians

Gr

Powers 1953 Activity Aleut volcanoes

Gr

Powers 1956 Activity AK volcanoes 1949-53

V

Powers 1958 Ak. Penin Aleut Is

Powers, S.

Powers 1916 Changes in Bogoslof volc

Presser, T. S.

Keith \& others 1981 Chem \& Isot data Big Windy Creek HS

Prosser, พ. T.

Prosser 1912 Volcanic road-building

$\mathrm{H}, \mathbf{V}$ 
Pulpan, H.

Dixon \& Pulpan 1986 crustal structure-Dall City [abs.] Ps Kienle \& Pulpan 1975 Tide caused quakes at Augustine [abs.] Ps,V Kienle \& others 1981 subd \& magma E Aleut arc [abs.] $R, P G$ Kienle \& others 1981 Volcanic centers Katmai [abs.] $V, R$ Kienle \& others 1983 Magmatism subduction $E$ Aleutian arc $V, P G$ Pulpan \& Rienle 1978 Seismic \& volcanic risks, Alaska V,Eg

Pyle, W. D.

Baker \& others 1977 Geotherm springs-salmon hatchery site R,DP,Fs is

Queen, I. D.

Motyka \& Queen 1984 Makushin fluids samps \& well $10 \mathrm{~g}$ Fs,Ff,Fw,PG Motyka \& others 1986 Makushin well chem equilib *,FW,Fs, Ff, HA, RM Nye \& others 1984 Geol map Makushin geothermal area Gs Queen 1984 Lith $\log$ \& harotherm alt of core from Makushin $\mathrm{HA}$ Queen 1987 Alt, H2O-rock equil, Makushin (thesis) HA, Fw, Gs, GC,HS Queen \& Motyka 1984 Changes in Makushin geoth system [abs.] HA

Radke, I. F.

Hobbs \& others 1977 Eruption of Augustine

Stith \& others 1977 Nuee ardent Augustine Volc

Ramdohr, P.

Ramdohr 1962 Magnetite from fumaroles VTTS (Ger)

HA

Ratte, J. C.

Richter \& others 1984 Shield volc Wrangell Mts

Ray, D. K.

Ray 1967 Geochem \& petro Mt Trident andesites (thesis) PG Fay \& others 1966 Petro \& geochem Mt Trident andesites [abs.] PG

Reading, $\mathbf{E}$.

Henning \& others 1976 Alaska's volcanoes $\mathbf{V}, \mathbf{R}$

Reck, H.

Reck 1930 Review VTTS (Ger)

Reed, B. I.

Detterman \& Reed 1964 Prelim geol map Iliamna Q Detterman \& Reed 1968 Geol Iliamna Q

Detterman \& Reed 1973 Surficial deposits Iliamna $Q$ 
AUTHOR

TOPIC

Detterman \& Reed 1980 strat, struct, econ geol Iliamna $Q$

Gr

Reed Lanphere 1972 Geol map Ak-Aleut batholith $\mathrm{K} / \mathrm{Ar}$ ages

Gr

Reed \& Ianphere 1973 Ak-Aleut bathollth, geochron \& chem

Reed \& Ianphere 1973 Plutonic rocks Ak-Aleut batholith

Gr

Gr

Reed, M. J.

Reed o others 1983 Data low temp geothermal systems US HS,R,Fs

Reeder, J. W.

Denig-Chakroff o others 1985 Development pot Mak reservoir Er,DP

Economides \& others 1981 Unalaska geothermal development DP

Economides \& others 1982 Eng,geol anal geothermal sites . EF,Er

Motyka \& others 1980 Assmt therm spr S SE Ak R,Fs

Nichols \& Reeder 1983 Ak geothermal \& hydrotherm development $R, D P$

Nye others 1986 Petro geochem Quat volc Makushin *,V,Gs,PG

parmentier \& others 1983 Geol \& hydrotherm alter Makushin Gs, HA

Reeder 1981 Initial assmt hydrotherm Summer Bay Unalaska Er,Gs

Reeder 1981 V-D hydrotherm malfest Unalaska [abs.] Gs, Ff

Reeder 1982 Hydrotherm potential Aleut arc - Makushin [abs] DP

Reeder 1982 Hydrothermal resources Makushin region DP

Reeder 1982 Hydrothermal resources N Unalaska Is Fs, Ff

Reeder 1983 Prelim dating Holo volcanic E Aleut Is [abs.] $V, G r$

Reeder 1984 Fault \& dike orientation Makushin [abs.] Gr

Reeder 1984 Okmok

Reeder 1986 Ground stabllity, spring water Broad Bay Eg,Fs,Gs

Reeder \& others 1977 Selsm Augustine volc [abs.] V,Ps

Reeder \& others 1980 Ak. geothermal program

Reeder \& others 1980 Geothermal implementation plan

Reeder \& others 1982 Econ \& eng geoth develop Makushin EF,Eg,DF

Reeder others 1985 Geol geotherm resource Makushín R,Gs

Reger, R. D.

Forbes others 1979 Geol, geoph assmt geothrm pot Pilgrim Gs,Ps KIIne \& others 1980 surf geol \& arililng Pilgrim HS Gs, Er

Reger 1978 Recon geol capital site

Reger \& Carver 1978 Recon geol materials map capital site $G r$

Turner others 1980 sum geol geophys invest P1Igrim spr RM

Reid, M. R.

Nye \& Reid 1986 Geochem pri lava Okmok Volc: arc magmagenesis PG

Nye \& others 1983 parental magmas Okmok: arc magmagen [abs.]. PG

ReifenstuhI, R. R.

Decker \& others 1984 Geol data Russian Mission A-3 Quad Gr

Decker \& others 1984 Geology sleetmute B-5 Quad Gr

Reifenstuhl 1984 Crawflsh Inlet Pluton Baranof Is [abs.] Gs,PG

Reifenstuhl 1984 Geol \& geophys Goddard HS (thesis) Gs,Ps,Fs

Relfenstuhl 1986 Geol Goddard Hot Springs Gs,Ps,Fs

Robinson others 1984 Bdrck geol Chuilnuk \& Klokluk Mts [abs] Gr 
AUTHOR

TOPIC

Robinson others 1984 Geologic map sleetmute B-5 \& Gr Robinson others 1986 Geol map Mt. Michelson C-4 Quad Gr

Reiser, H. N.

Chapman o others 1975 Prelim geol map Tanana \& NE Kantishan Q Gr

Chapman \& others 1982 Recon geol map Tanana Q

Keller \& Reiser 1959 Geol Ratmai

Gr

Gr

Reitsema, R. H.

Reitsema 1979 Gases of mud volc Copper River basin Fs

Reneau, D.

Yehle \& others 1985 Geol frm drilling in Copper R. basin Gr

Rennick, P.

Henning \& others 1981 Wrangell-st Elias wilderness

C

Republic Geothermal Inc.

Republic 1982 Unalaska Gtrml Proj IA Er,Hs,Fs,Ff,Gs,Ps,DP, RM, HA Republic 1983 Unalaska Gtrml Proj IB Er,HS,Fs,Ff,Gs,Ps,DP, RM, HA Republic 1984 Unalaska Gtrml Proj II Er,HS,Fs,Fw,Gs,Ps,DP, RM, HA Republic 1985 Unalaska Gtrml Proj III *,Er,HS,Fw, Gs,Ps,DP, RM, HA

Richards, T.

Salnsbury \& others $1970 \mathrm{Geol}$ min dep geochem \& rad serpentine Gr

Richter, D. H.

Richter 1976 Geol map Nabesna Q

Richter \& others 1979 Geol map Gulkana A-2 Q

Richter \& others 1984 Shield volc Wrangell Mts

Riehle, J. R.

Riehle 1985 Recon Holo tephra deposits upper Cook Inlet

Riehle \& others 1981 Lahars Crescent River Lower Cook Inlet

Rioux, R. I.

Godwin \& others 1971 Classif of public land for geothermal R,DP Roberts, E. D.

Nehring \& others 1979 sulfate geotherm western U. S. R,Fs Robinson, G. D.

Robinson 1948 Exploring Aleutian volc V,E 
Robinson, M. S.

Robinson \& Decker 1986 Ages analysis from SW Alaska Gr,PG

Robinson \& Stevens 1983 Geol map Seward Penin

Robinson \& Stevens 1984 Geol map Seward Penin

Gr

Robinson \& others 1984 Bdrck geol Chuilnuk \& Klokluk Mts [abs] Gr

Robinson o others 1984 Geologic map sleetmute B-5 Q Gr

Robinson \& others 1986 Geol map Mt. Michelson C-4 Quad Gr

Robinson \& others 1986 Rocks from sleetmute, Russian Mission Q PG

Roehn, J. C.

Roehn 1941 Pumice deposits Katmal

Rogers, J. A.

Rogers 1986 Geology Shublik Mts

Gr

Romick, J. D.

Motyka \& others 1985 Geol geoc geophys Akutan *,Gs, Fs, Ps, RM, Ff, DP Romick 1982 Ig petro \& geochem N. Akutan Is (thesis) PG

Romick $1983 \mathrm{Ig}$ petro \& geochem N. Akutan Is [abs.]

Romick 1986 Ig pet and geochem N. Akutan

Romlck \& Swanson 1983 Petro \& fract lava Akutan Is [abs.]

$P G$

PG

PG

Rosenbruch, J. C.

Rosenbruch \& Bottge 1975 Econ potent 3 sites Ak

Rosenthal, C. H.

Henning \& others 1976 Alaska's volcanoes

$\mathbf{V}, \mathbf{R}$

Rosenthal, F. W.

Rosenthal 1908 Hot springs of southeast Alaska $\quad H, R$

Rossman, D. L.

Rossman 1959 Geol \& ore dep NW Chichagof Is

Rubenstone, J. L.

Rubenstone \& others 1985 Isot \& trace elem katmal [abs.] PG Russell, S. L.

Smith \& others 1978 Data \& therm energy est young ig sys US R, HS 
AUTHOR

TOPIC

Sainsbury, C. L.

Bunker \& others 1977 Prelim radio ages of rocks Kigluaik Mts Sainsbury \& others $1968 \mathrm{SnO}_{2}$ Humbolt $\mathrm{Cr}$ Serpentine-Kougarok Sainsbury \& others $1970 \mathrm{Geol}$ min dep geochem \& rad serpentine

Twenhofel \& Sainsbury 1958 Fault patterns SE AK

Gr

Gr

Gr

Gr

Sammel, E. A.

Sammel 1979 Low temp. geothermal in U.S.

$\mathbf{R}$

Sass, J. H.

- Lachenbruch \& others 1984 Geotherm Prudhoe Bay

HS

Nathenson \& others 1983 Regional heat flow

$R$, HS

Sayre, J. D.

Sayre \& Hagelbarger 1918 Temps in VTTS

H, HS

Sbar, M. L.

- Sbar \& Matumoto 1972 Refraction VTTS

$\operatorname{Pr}$

Scheidegger, K. F.

Federman \& Scheidegger 1984 Distal tephra 1912 Novarupta Scheidegger \& Kulm 1973 CYclic Aleut volc ash DSDP 178 [abs.] V Scheidegger \& others 1977 Ash volc Aleut \& Kamchat arc [abs.]

$\mathbf{v}$

Schell, L. C.

$\stackrel{2 .}{4}$

Conwell \& Schell 1977 Energy resource map Alaska

$\boldsymbol{R}$

Schmincke, H. U.

Johnson \& others 1977 Augustine Volc, evaluat hazards [abs.] V,Eg Schmincke \& Johnson 1977 Pyroclastic flows Augustine [abs]

Schmoll, H. R.

Ferrians \&chmoll 1957. Wisc progalcial lake Copper River bsn Gr Ferrians others 1958 pleist volc mudflow Copper River basin V r

Schnell, R. C.

Schnell \& Sheridan 1986 Arctic gas \& aerosols-Augustine [abs.] V Schrader, F. C.

Schrader \& Spencer 1901 Geol \& min res Copper River dist H, Gr 
AUTHOR

TOPIC

Seed, S. M.

Turner \& others 1980 Geothermal resources Alaska

R, Fs

Self, S.

Kienle \& others 1978 Form. 2 maars behlnd volc arc [abs.]

Kienle \& others 1980 Ukinrek Maars 1977 eruption

Self \& others 1978 Mechanisms \& deposits Ukinrek [abs.]
self \& others 1980 Ukinrek Maars II deposits \& formation

$V$
$V$
Ps, Gs, V
$V$

Shackelford, D. C.

Shackelford 1983 Hlst activity Pavlov Volc

Shaw, G. E.

Kienle \& Shaw 1977 Augustine erupt - Initial phase 1976

Shaw, H. R.

Smith \& Shaw 1979 Igneous related geothermal systems

Smith \& others 1978 Data \& therm energy est young 19 sys US R,HS

Shel1khov, G. I.

Shelikhov 1790 Voyage to America $1783-1786$

$\mathbf{H}, \mathbf{C}$

Sheppard, D. S.

Motyka \& others 1986 Makushin well chem equilib *,FW,Fs,Ff,HA,RM Sheridan, P. J.

Schnel1 \& Sheridan 1986 Arctic gas \& aerosols-Augustine [abs.] V Sherman, G.

Hansen others 1981 Mineral potential Ak Penin.

Gr

Shew, N.

Wilson \& shew 1981 Prelim K-Ar studies circle Q Gr

Shipley, J. W.

Shipley 1919 VTTS

Shipley, 1920 Chem obs VTTS

Shipley 1920 Ratmai gas \& encrustations

FA,

$H A, F f, V$

Shore, R. A.

Shore 1985 Resist survey \& interp PE,RM 
AUTHOR

siebert, $\mathrm{L}$.

Siebert \& others 1986 Debris avalanches Augustine [abs.] V

Simkin \& others 1981 Volcanoes of the World V,R

silberling, N. J.

Jones \& others 1984 Terrane map Alaska Gr

Silberman, M. I.

Silberman \& others 1978 Age of rocks Ruby, Medfra \& adj $Q$ Gr

Winkler \& others 1981 Folio. Valdez $Q \quad$ Gr

simkin, T.

Simkin \& others 1981 Volcanoes of the World $V, R$

simons, F. S.

Simons \& Mathewson 1955 Geol Great sitkin Is $\quad$ Gr

Sinha, A. K.

Myers \& others 1984 Assim crust by basalt magma Edgecumbe PG

Myers \& others 1986 Isot var Adak \& Atka volc plumb V,PG,Gr

Sloan, C. E.

Sloan 1976 Chem anal Bailey Bay HS Fs

Sloan 1976 Chem anal Bell Is HS

sloan 1976 Chem anal Chlef Shakes HS Fs

Smith, E. P.

Iachenbruch \& others 1984 Geotherm Prudhoe Bay HS

Smith, J. G.

Berg \& others 1978 Geol map Ketchikan \& Prince Rupert Q Ak. Gr ichter \& others 1984 Shield volc Wrangell Mts

Smith, R. I.

Miller \& Smith 1975 Ak geothermal study

Miller \& Smith 1975 Ash flows Ak Penin prelim rpt [abs.] V,Gr

Miller \& Smith 19762 caldera forming eruptions Umnak

Miller \& Smith 1976 Ash flows Wrangell volcano

Miller \& Smith 1976 New volcanoes Aleutian arc

Miller \& Smith 1977 Mobile ash flows Aniakchak \& Fisher calds

Miller \& Smith 1983 Calderas E Aleutian arc [abs.]

Richter \& others 1979 Geol map Gulkana A-2 Q 
Smith \& Shaw 1979 Igneous related geothermal systems R,HS Smith \& others 1978 Data \& therm energy est young ig sys US R,HS

Smith, T. E.

Robinson \& others 1986 Geol map Mt. Michelson C-4 Quad Sainsbury others $1968 \mathrm{SnO}_{2}$ Humbolt $\mathrm{Cr}$ Serpentine-Kougarok

Smith, W. R.

Smith 1925 Anlakchak Crater

Smith 1925 Cold Bay Katmal dist

Smith \& Baker 1924 Cold Bay-Chignik dist

$\mathbf{G r}, \mathrm{H}$

$\mathrm{Gr}, \mathrm{H}$

Gr, H

Snyder, G. I.

Drewes \& others 1961 Geol Unalaska \& adjacent shelf

Fraser \& Snyder 1959 Geol 5 Adak \& Kagalaska Islands

snyder 1954 Eruption Trident Katmal

Snyder 1959 Geol Iittle sitkin Is

Snyder \& Fraser 1963 Plllowed lavas Unalaska

Gr

Gr

V

Gr

Gr

Solie, D. N.

Gilbert \& Solie 1983 Prelim geol map Mc Grath A-3 Quad

Solle 1983 Plutons in Mc Grath A-3 Quad

Gr

Gs

Sorey, M. I.

Reed others 1983 Data low temp geothermal systems US HS,R,Fs

Sosman, R. B.

Sosman 1919 Temp in fumaroles VTTS H,HS

Spencer, A. C.

schrader \& Spencer 1901 Geol \&in res Copper River dist H,Gr Spencer, S. G.

Spencer others 1982 Anal geothrm res devel Unalaska EF,DP

Spurr, J. E.

Spurr 1900 Recon in SW Ak $1898 \quad H, G r$

stearns, H. T.

stearns \& others 1937 Thermal springs in U.S. R, Fs

stearns, N. D.

Stearns \& others 1937 Thermal springs in U.S. R,Fs 
steele, J. I.

Blackwell \& steele $1986 \mathrm{NA}$ geothermal map [abs.] R,HS steele, . $C$.

Lecompte \& steele 1981 Map Iandsat Chignik \& Sutwik Is $Q$

stefano, R. R.

Stefano 1974 Low temp use Pilgrim HS

stefano 1975 Pilgrim HS could heat Nome

Stephens, C. A.

Osterkamp \& others 1979 Conduct \& hydrol meas Pilgrim HS [abs] Ps Osterkamp \& others 1980 Recon study access power Pilgrim Ps,Gs,DP

stephens, C. D.

Page \& others 1982 Seism Spurr, Redoubt, \& Illamna [abs.]

stern, R. 0 .

Stern \& Stirling 1982 Pilgrim Hot Springs Road

stevens, D. L.

Robinson \& Stevens 1983 Geol map Seward Penin

Robinson \& Stevens 1984 Geol map Seward Penin

stewart, R. J.

stewart 1975 Late Cenozoic erupt Aleutians \& Ruril Is arcs

Still, P. J.

still 1980 Index water qual records to 1978

stirling, s.

stern \& stirling 1982 Pilgrim Hot springs Road

stith, J. I.

Stith \& others 1977 Nuee ardent Augustine Volc

stoltzfus, C. F.

stoltzfus 1982 Copper River basin planning study 
Stone, D. B.

Barrett \& others 1977 Model of Augustine Volcano [abs.]

stone \& Rienle 1975 Pavlov

stone \& Packer 1972 Paleomag VTTS [abs.]

stone \& others 1971 Magnetic anomalies VTTs [abs.]

V, Ps

$\mathrm{V}$

Pr

$\operatorname{Pr}$

stoney, G. M.

stoney 1884 Volcano in Bering sea

$\mathrm{H}, \mathrm{V}$

stoney 1900 Naval expl Alaska

$\mathbf{H}, \mathbf{G r}$

strong, D. F.

Harmon others 1984 Augustine chem \& lsot character [abs.] PG

sturm, $M$.

Benson \& others 1985 Glacio-volcano studies Mt. Wrangell

Swanson, J. R.

Brook \& others 1979 Hydrothermal systems $<90$ deg

Mariner \& others 1978 Data for hydrothermal systems $>=90$

R, Fs

R,F $\mathbf{E}$

Swanson, S. E.

Daley \& Swanson 1985 Low press fractionation Augustine [abs.] PG Forbes \& others 1979 Geol, geoph assmt geothrm pot Pilgrim Gs,Ps Rienle Swanson 1980 Volcanlc hazards Augustine

Kienle \& Swanson 1983 Volc E Aleut arc I Quat \& Holo cntrs

$\mathbf{V}, \mathbf{E g}$

Kienle \& Swanson 1983 Volc E Aleut arc Quat \& Holo centers

V, PG

Kienle \& Swanson 1985 Volc hazards Augustine 2nd ed.

$V, P G$

Rienle \& others 1981 Subd \& magma E Aleut arc [abs.]

Kienle others 1981 Volcanic centers Katmal [abs.]

$\mathrm{V}, \mathrm{Eg}$

Kienle others 1983 Magmatism subduction E Aleutian arc V,PG

Motyka o others 1985 Geol geoc geophys Akutan *, Gs, Fs, Ps, RM, Ff, DP

Neal \& Swanson 1983 Petro geochem Westdahl \& Pogromnl [abs.] PG

Nye \& Swanson 1986 Chem strat magma plumb Makushin [abs] V,Gs,PG

Nye Swanson 1987 Makushin magma chamber

Nye others 1986 petro geochem Quat volc Makushin *,V,Gs,PG

Romick \& Swanson 1983 petro \& fract lava Akutan Is [abs.] PG

Swanson $1983 \mathrm{Min}$ \& fract Makushin volc [abs.] PG

Swanson \& Blum 1984 Evol of volc centers Aleutian arc [abs] $V, G r$

Swanson \& Rlenle 1982 Volc centers Katmal

Swanson others 1980 Bedrock geol pligrim springs area Gs

Swanson \& others 1981 Geol \& petro Kaguyak crater [abs.] PG

Swanson \& others 1983 petro Makushin volc [abs.] PG

Swanson \& others 1986 Magmatic evolution Augustine [abs.] PG,V

Turner \& Swanson 1981 Continent rifting new model seward Pen Gr

Turner \& others 1979 Geol \& tect setting Pilgrim spr [abs.] Gs

Turner \& others 1980 sum geol geophys invest Pilgrim spr RM

Turner \& others 1981 Continent rifting new model seward Pen Gr 
AUTHOR

Sydora, R.

Wescott \& others 1979 Resis survey P1lgrim HS [abs.]

Wescott \& others 1980 Resis survey Pilgrim spr area

Ps

Ps

Sykes, I.

House \& others 1981 Selsmic gap near Unalaska

Gs

Taber, B.

Hopkins \& Taber 1962 Stratigraphy Manley HS

Gs

Taber, J. T.

Taber 1972 Seismicity geotherm areas Ak other (thesis) R, Pr

Tagg, A. R.

Grantz \& others 1962 Saline springs Copper River basin

Fs

Tailieur, I. I.

Blanchard \& Tailleur 1982 Prelim geothermal 1sograd map NPRA Patton \& others 1968 Reg geol map Shungnak \& Ambler River $Q$

HS

Gr

Tams, E.

Tams 1924 Katmai (Ger)

$\mathbf{V}, \mathrm{H}$

Tanner, I.

Nehring \& others 1979 sulfate geotherm western U. S.

R, Fs

Tazieff, H.

Bordet \& Tazieff 1963 Erupt of Katmal \& ignimbrites

Bordet \& others 1963 Katmal

$\mathbf{V}$

Thomas, J.

Reeder \& others 1977 Selsm Augustine volc [abs.]

V,Ps

Thompson, J. M.

Thompson \& Keith $1984 \mathrm{Cl}$ \& in waters VTTS [abs.]

Fs

T111, A. B.

Till 1984 Redoubt-strat \& volc hazards [abs.]

$E g, P G$

Todd, พ. c.

Sainsbury \& others $1968 \mathrm{SnO}_{2}$ Humbolt $\mathrm{Cr}$ Serpentine-kougarok 
Trible, $\mathrm{M}$.

Stone others 1971 Magnetic anomalies VTTS [abs.] Pr

Tripp, R. B.

Menzle \& others 1983 Mineral assmt circle Quad Gr

Turner, D. I.

Dean o others 1981 Remote sensing Pligrim Springs Ps

Forbes \& others 1975 Fission track age \& geotherm grad [abs.] HS

Forbes \& others 1977 Fission track age geothermal gradient ES

Forbes \& others 1979 Geol, geoph assmt geothrm pot Pilgrim Gs, Ps

Forbes \& others 1979 Pilgrim springs hydrothermal system RM

Motyka \& others 1985 Geol geoc geophys Akutan *, Gs, Fs, Ps, RM, Ff, DP

Nye \& Turner 1986 Geology \& geochemistry Spurr [abs.] Gs,PG,V

Swanson others 1980 Bedrock geol Pllgrim springs area Gs

Turner \& Forbes 1980 Geol geophy stdy P1lgrim *, Gs, Ps, RM, Fs, Fw, HS

Turner Nye 1986 Geochronology Mt. Spurr V

Turner \& Swanson 1981 Continent rifting new model seward Pen $G r$

Turner \& Wescott 1982 Prelim invest gthrm I susitna Gs, Ps,GC,ES

Turner \& Wescott 1986 Geotherm invest Mt. Spurr *,R, Ps,GC,V,Gs, RM

Turner \& others 1975 Rad dates Ak 1975 compilation Gr

Turner \& others 1979 Geol \& tect setting Pilgrim spr [abs.] Gs

Turner \& others 1980 Geothermal resources Alaska R,Fs

Turner \& others 1980 sum geol geophys invest Pilgrim spr RM

Turner \& others 1981 Continent rifting new model seward Pen $G r$

Turner \& others 1983 Sum, eval gthrm exp Copper $R$ bsn Gs, Ps, Fs, RM

Turner \& others $1986 \mathrm{Mt}$. Spurr geothermal project $\quad R, G s, V$

Turner \& others $1986 \mathrm{Hg}$ and He surveys Mt. Spurr Gc,R

Wescott \& Turner 1981 Geol \& geophys Chena HS *,Gs,Ps,GC

Wescott \& Turner 1981 Geotherm recon C Seward Pen Gs, Ps, GC, HS, RM

Wescott \& Turner 1982 Geotherm assmt parts of Ak R,Gs,Ps,Gc

Wescott \& Turner 1983 Geotherm expl E Copper R basin Rs,GC,Fs, FW

Wescott \& Turner 1983 Geotherm potent Copper R basin Gs,Ps,GC,DP

Wescott \& Turner 1985 Geotherm invest Copper *, Gs, Ps,Gc,DP, Fs, Fw

Wescott * others 1982 Geophys survey Hot Springs Akutan Is Ps

Wescott \& others $1982 \mathrm{He}$ \& Hg survey parts Unalaska Gc

Wescott \& others 1985 Prelim rept gthrml Invest Mt Spurr Gs,Ps,GC

Wescott \& others 1986 Geophyslcal surveys Mt. Spurr Ps, R

wilson \& Turner 1975 Rad age map Aleutlans $\quad$ Gr

Wilson \& Turner 1975 Rad age map $N$ Ak $\quad$ Gr

Wilson \& Turner $1975 \mathrm{Rad}$ age map SC AK $\therefore$ Gr

Wilson \& Turner 1975 Rad age map SE AK $\quad$ Gr

Wilson \& Turner 1975 Rad age map SW AK Gr

Twenhofe1, W. S.

Twenhofel Sainsbury 1958 Fault patterns SE Ak Gr 
Tysdal, R. G.

Detterman \& others 1976 Geol map by faults in Kenal \& Tyonek Q Gr Updike, R. G.

Updike 1986 Construction materials Makushin

Van Wormer, D.

Forbes \& others 1975 Geophysical recon. Pilgrim Springs

Ventaminov, I.

Veniaminov 1840 Notes on islands Unalaska district Viglino, J. A.

Viglino \& others 1985 Isot evid magma comp in fum cond Augst $V, F f$ VonLangsdorff, G. H.

VonLangsdorff 1814 Voyages \& travels 1803-1807

Waldron, H. H.

Kennedy \& Waldron 1955 Geol Pavlof volcano

Waldron 1961 Geol recon Frosty Peak volc

Wallace, R. E.

Cady \& others 1955 Geology central Kuskokwim

Waller, J. A.

Page \& others 1982 Seism Spurr, Redoubt, \& Iliamna [abs.]

Wanek, A.

Wanek 1973 Geotherm areas by meridian \& acreage

Ward, P. I.

Matumoto \& Ward 1967 Microquake study Ratmai

Ward \& Matumoto 1967 Sum volc \& seismic activity Ratmai

Ward \& Ward 1966 Volc activity in Katmal

Ward, s. N.

Ward Ward 1966 Volc activity in Katmal 
Waring, G. A.

Stearns \& others 1937 Thermal springs in U.S.

Waring 1917 Mineral springs Ak

Warling 1965 Thermal springs uS \& world - a summary

R, Fs

Fs, R

Fs

Wayland, R. G.

Godwin others 1971 Classif of public land for geothermal R,DP

Weber, F. R.

Cady \& others 1955 Geology central Kuskokwim

Foster \& others 1970 Geol Yukon-Tanana upland [abs.]

Gr

Foster others 1973 Geology Yukon-Tanana upland

Gr

Gr

Wendler, G.

Wendler 1967 Heat flow Mt. Wrangell V,HS

Wescott, $\mathbf{E}, \mathbf{M}$.

Forbes \& others 1979 Geol, geoph assmt geothrm pot Pilgrim Gs,Ps Forbes others 1979 Pligrim springs hydrothermal system RM Motyka \& others 1985 Geol geoc geophys Akutan *, Gs, Fs, Ps, RM, Ff, DP Turner \& Wescott 1982 Prelim invest gthrm I Susitna Gs,Ps,Gc,HS Turner \& Wescott 1986 Geotherm invest Mt. Spurr *,R,Ps, GC, V,Gs, RM Turner \& others 1980 sum geol geophys invest Pilgrim spr RM Turner \& others 1981 continent rifting new model seward Pen Gr Turner \& others 1983 sum, eval gthrm exp Copper R bsn Gs,Ps, Fs, RM Turner \& others $1986 \mathrm{Mt}$. Spurr geothermal project R,Gs,V Turner \& others $1986 \mathrm{Hg}$ and He surveys Mt. Spurr Gc, R Wescott $1981 \mathrm{He}$ \& $\mathrm{Hg}$ cent Seward Penin Wescott $1981 \mathrm{He}$ \& He surveys Chena HS

Wescott \& Turner 1981 Geol geophys Chena HS

Wescott Turner 1981 Geotherm recon C Seward Pen Gs, Ps,GC, HS, RM Wescott \& Turner 1982 Geotherm assmt parts of Ak R,Gs,Ps,GC Wescott \& Turner 1983 Geotherm expl E Copper $R$ basin PE,GC,Fs, FW Wescott \& Turner 1983 Geotherm potent Copper $R$ basin GS,Ps,Gc,DP Wescott \& Turner 1985 Geotherm invest Copper *, Gs, Ps, GC,DP, Fs, Fw wescott witte 1982 Gravity survey I Susitna basin Ps Wescott others 1979 Resis survey Pligrim HS [abs.] Ps Wescott \& others 1980 Resis survey Pilgrim spr area Ps Wescott \& others 1981 Geophys survey summer Bay Ps Wescott \& others 1982 Geophys survey Hot Springs Akutan Is Ps Wescott \& others $1982 \mathrm{He} \& \mathrm{Hg}$ survey parts Unalaska GC Wescott \& others 1985 Prelim rept gthrml invest Mt Spurr Gs,Ps,GC Wescott others 1986 Geophysical surveys Mt. Spurr PS,R Wescott \& others 1986 Ice thickness Mt. Spurr summit $\quad$ Ps

Westdahl, F.

Westdahl 1900 Mountains on Unimak 
Wharton, G. B.

Benson others 1975 Glac \& volc studies Mt. Wrangell

Benson \& others 1985 Glacio-volcano studies Mt. Wrangell

White, D. E.

Godwin \& others 1971 Classif of public land for geothermal $R, D P$ Grantz \& others 1962 Saline springs Copper River basin

White \& Williams 1975 Assmt geothermal resources US R, Fs, HS

White, L. D.

Harmon \& others 1982 Isotopes from Augustine fumaroles

Nehring \& others 1979 Sulfate geotherm western U. S.
Viglino \& others 1985 Isot evid magma comp in fum cond Augst V,Ff

Whitehead, H. C.

Grantz \& others 1962 Saline springs Copper River basin

Fs

Whymper, $\mathbf{F}$.

Whymper 1868 Journey Norton sound to Fort Yukon

Wilcox, R. E.

Gates \& others 1971 Geol Near Islands

Wilcox 1953 Eruption Mt Spurr

Wilcox 1959 Volcanic ash falls Alaska

Willaims, D. I.

White \& Williams 1975 Assmt geothermal resources Us

R,Fs, HS

Williams, H.

Williams 1955 Prelim geol Katmal \& VTTS

Williams \& others 1956 Mt Katmal \& VTS new interp 1912 eruptn V Wllliams, J. R.

Ferrians \& others 1983 Copper River basin

Williams 1985 Eng geol map Copper River basin

Williams \& Johnson 1980 Map Tert \& Qut deposits Valdez $Q$

Gr

Eg

Wi1liams, T.

Kline others 1980 surf geol \& drilling Pllgrim HS

Gs, Er 
Wilson, C. R.

W11son \& Forbes 1969 Infrasonic waves volc erupt [abs.] V Wilson \& Forbes 1969 Infrasonic waves Ak volc eruptions V Wilson \& Rienle 1976 Infrasonic signals Augustine volc [abs.] V

Wilson, F. H.

Case \& others 1980 Tertiary volc centers Ak Penin.

Detterman \& others 1979 Geol map Chignik \& Sutwik Is Q

$\mathbf{G r}, \mathbf{V}$

Detterman \& others 1981 Geol map Chignik \& sutwik Is $Q$

Gr

Detterman \& others 1981 quat geol map Chlgnik \& Sutwik Is Q

Gr

Detterman \& others 1983 Geol map Ugashik-Bristol Bay-Karluk \&

Gr

Detterman \& others 1985 Geol map Ugashik \& W Karluk Q

Gr

Detterman \& others 1986 Quat map Ugashik-Bristol Bay-Karluk Q

Gr

Turner \& others 1975 Rad dates Ak 1975 compilation

Wilson 1977 Plutonic rocks SW Ak data compllation

wilson \& Shew 1981 Prelim $K-A r$ stuales Circle $Q$

Wilson \& Turner 1975 Rad age map Aleutians

Wilson \& Turner 1975 Rad age map N AK

W1Ison \& Turner 1975 Rad age map SC Ak

Wilson Turner 1975 Rad age map SE AK

W1lson \& Turner 1975 Rad age map SW Ak

w1lson \& others 1985 Alaska Peninsula terrane

Yount \& others 1985 Eruption Mt Veniaminof

Gr

Gr

Gr

Gr

Gr

Gr

Gr

Gr

Gr

Yount \& others 2985 New Holo vent Port Moller \& Stepovak Bay Q

Wiltse, M. A.

Reeder \& others 1980 Ak. geothermal program

Wiltse 1986 Radon hazard assessment Circle HS

DP

Ge

Winkler, G. R.

winkler \& others 1981 Folio Valdez $Q$

Gr

witte, $w$.

Motyka \& others 1985 Geol geoc geophys Akutan *, Gs, Fs, Ps, RM, Ff, DP Wescott \& Witte 1982 Gravity survey I Susitna basin

Wescott \& others 1981 Geophys survey Summer Bay

Ps

Wescott \& others 1982 Geophys survey Hot Springs Akutan Is *s

Wescott \& others $1982 \mathrm{He}$ \& Hg survey parts Unalaska

Wescott others 1986 Geophysical surveys Mt. spurr

Wescott \& others 1986 Ice thickness Mt. Spurr summit

Ge

Ps, $R$

Ps

Woodruff, I. G.

Woodruff Anderson 1980 Arrested magma mixing Pavlov

PG

Woodward-clyde

Woodward-clyde 1983 Geothermal development Pilgrim spr

DP 
Workman, พ. B.

Workman 1979 signif volc in prehist of subarctic

Wright, C. W.

Wright 1906 Nonmetallic deposits SE Ak.

Wright \& Wright 1908 Ketchikan \& Wrangell mining districts

Wright, F. E.

Wright \& Wright 1908 Ketchikan \& Wrangell mining districts Gr,H Yeend, W. E.

Chapman \& others 1975 Prelim geol map Tanana \&E Kant1shan Q Gr

Chapman \& others 1982 Recon geol map Tanana $Q$

Menzie \& others 1983 Mineral assmt Circle Quad

Patton others 1978 Geol map Melozitna $Q$

Yehle, L. A.

Nichols Yehle 1961 Anal gas water Copper River basin

Fs

Nichols \& Yehle 1961 Kud volc Copper River basin Fs

Nichols \& Yehle 1969 Eng geol map SE Copper River basin Gs

Richter \& others 1979 Geol map Gulkana A-2 Q

Gr

Yehle \& Nichols 1980 Recon map Chetaslina debris flow Copper $R V$

Yehle \& others 1985 Geol frm drilling in copper R. basin

Gr

Yount, M. E.

Detterman \& others $1979 \mathrm{Geol}$ map Chignik \& Sutwik Is Q Gr

Detterman \& others 1981 Geol map Chignik \& sutwik Is Q $Q$ Gr

Detterman \& others 1981 Quat geol map Chignik \& sutwik Is Q Gr

Detterman \& others 1983 Geol map Ugashik-Bristol Bay-Karluk Q Gr

Detterman \& others 1985 Geol map Ugashik \& W Karluk Q Gr

Detterman \& others 1986 Quat map Ugashik-Bristol Bay-Karluk Q Gr Yount 1984 Redoubt mineralogy \& chem [abs.] Yount \& others 1985 Eruption Mt Veniaminof

Yount \& others 1985 New Holo vent Port Moller stepovak Bay Q V

Zies, E. G.

Allen \& Zies 1923 Chem study fumaroles Katmal region Ff

zies 1921 Hot springs in VTTS

Zies 1924 Fumarolic Incrustations Katmal [abs.]

zies 1924 Fumarolic incrustations VTTS

HA

zies 1929 VTTS I-fumarolic incrustations II-acid gases

zletz, I.

Andreasen \& others 1964 Geol inter mag \& grav Copper Rvr basn Pr 
ALASKA GEOTHERMAL BIBLIOGRAPHY

SECTION III

GEOTHERMAL SITE IISTING

(see Table I - Abbreviations used in short references - Pg. 223) (see Table II - Codes used in short references - Pg. 227) (see Figures for geothermal site locations - Pgs. 233-243) 
Adak $\quad A A-4$

Berry others 1980 Thermal spring list U. S.

Bliss 1983 Ak basic data thermal springs wells

Coats 1947 Geol N Adak Island

Coats 1952 Magmatic different Adak \& Kanaga Islands

Coats 1956 Geol N Adak Island

Coats 1956 Recon geol $\mathrm{W}$ Aleutian Islands

Conrad \& Kay 1984 Inclusions Adak Is-nature of primary magma PG

Fraser \& Snyder 1959 Geol S Adak \& Kagalaska Islands

$R, F s, F w$

Markle 1979 Geotherm Ak stte data base devel status

Miller 1973 Distribution chem analysis thermal springs

Motyka 1983 High temp hydrothermal resources Aleut arc R,Fs,Ff

Motyka \& others 1983 Geothermal resources of Alaska R,Fs,Ff, Fw

Myers \& others 1986 Isot var Adak \& Atka volc plumb

Peale 1886 Mineral springs of US

Turner \& others 1980 Geothermal resources Alaska

Waring 1965 Thermal springs US \& world - a summary

White \& Williams 1975 Assmt geothermal resources US

$\mathrm{V}, \mathrm{PG}, \mathrm{Gr}$

$\mathrm{H}, \mathrm{R}$

R,Fs

Fs

R, Fs, HS

Akun strait $\quad A A-23$

Berry others 1980 Thermal spring list U.S.

Bliss 1983 Ak basic data thermal springs \& wells

Byers \& Barth 1953 Volc activity Akun \& Akutan Islands

Coats 1956 Recon geol $\mathrm{W}$ Aleutian Islands

Miller 1973 Distribution \& chem analysis thermal springs

Motyka \&oorman 1981 Recon thermal spr Aleutian arc

Motyka \& others 1981 Assmt thermal spring Aleutian arc

Motyka \& others 1983 Geothermal resources of Alaska

Peale 1886 Mineral springs of us

Turner \& others 1980 Geothermal resources Alaska

Waring 1965 Thermal springs US \& world - a summary

$R, F \mathbf{R}, \mathrm{FW}$

Gr

Ak R, Fs

R,Fs, Ff

$R, F s, F f, G r$

R, Fs, Ff, FW

$\mathrm{H}, \mathrm{R}$

R, Fs

Fs

Akutan Volcano AA-2I

Brown 1899 Shishaldin

Byers \& Barth 1948 Geol Akutan Island

Byers \& Barth 1953 Volc activity Akun \& Akutan Islands

Davidson 1893 Eruption of Veniaminof

Finch 1935 Akutan volcano

House \& others 1981 Seismic gap near Unalaska

Miller \& Barnes 1974 Geotherm devel Ak [abs.]

$P, G r, V$

Miller \& Barnes 1976 Geotherm develop Ak summary

$D P, G r, V$

Motyka 1982 Fluid geochem Makushin \& Akutan geotherm area Ff,Fs

Motyka \& others 1983 Geothermal resources of Alaska R,Fs,Ff,Fw

Motyka \& others 1985 Geol geoc geophys Akutan *,Gs,Fs, Ps,RM,Ff,DP

Prosser 1912 Volcanic road-building

Reeder 1983 Prelim dating Holo volcanic E Aleut Is [abs.]

$\mathrm{H}, \mathrm{V}$

Romick 1982 Ig petro \& geochem N. Akutan Is (thesis)

$\mathbf{V}, \mathbf{G r}$

Romick 1983 Ig petro \& geochem N. Akutan Is [abs.]

PG

Romick 1986 Ig pet and geochem N. Akutan

Romick \& Swanson 1983 Petro \& fract lava Akutan Is [abs.]

Smith \& Shaw 1979 Igneous related geothermal systems

PG

PG

PG

$R, H S$ 
Swanson \& Blum 1984 Evol of volc centers Aleutian arc [abs] $V, G r$ Wescott \& others 1982 Geophys survey Hot Springs Akutan Is White \& W1111ams 1975 Assmt geothermal resources US R,Fs, HS

Anlakchak AA-34

Berry others 1980 Thermal spring list U.S. Bliss 1983 Ak baslc data thermal springs wells

Detterman \& others 1979 Geol map Chignik \& Sutwik Is Q Detterman \& others 1981 Geol map Chignik \& Sutwik Is $Q$ Detterman others 1981 Quat geol map Chignik \& Sutwik Is $Q$ Hansen \& others 1981 Mineral potential Ak Penin. Hubbard 1931 Geol Aniakchak \& Veniaminof [abs.] Hubbard 1931 World inside a mountain Knappen 1926 Geol min resources Aniakchak Knappen 1933 Anlakchak \& Veniaminof volcanoes [abs.] $R, F s, F w$ Lecompte \& Steele 1981 Map Landsat Chignik \& Sutwik Is $Q$ Lyle 1973 Geol \& mineral evaluation Anlakchak R drainage Markle 1979 Geotherm Ak site data base \& devel status $R, F s, G r, C$ Miller 1978 Alrfall pumice Antakchak

Miller \& Barnes 1974 Geotherm devel Ak [abs.] Miller \& Barnes 1976 Geotherm develop Ak summary Miller \& Smith 1976 New volcanoes Aleutian arc Motyka others 1981 Assmt thermal spring Aleutian arc R,Fs,Ff, Gr Motyka \& others 1983 Geothermal resources of Alaska R,Fs,Ff, Fw Reed \& others 1983 Data low temp geothermal systems US HS,R,Fs Smith 1925 Anlakchak Crater Smith \& Baker 1924 Cold Bay-Chignik dist Smith \& Shaw 1979 Igneous related geothermal systems Turner others 1980 Geothermal resources Alaska White \& W1Iliams 1975 Assmt geothermal resources Us $\mathrm{Gr}, \mathrm{H}$ Gr, H $\mathrm{R}, \mathrm{HS}$ R,Fs $R, F s, H S$

Arrigetch NC-39

Adams 1983 Geol northern Arrigetch pluton (thesis) Gr Adams 1984 Geol northern Arrlgetch Peaks pluton [abs.] Gr Berry \& others 1980 Thermal spring 1 lst U.S. Brosge Pessel 1977 Prelim recon geol map survey pass Q Gr Nelson \&rybeck 1978 Arrigetch Peaks \& Igikpak plutons Gr

Augustine sC-11

Barrett 1978 Magnetic model of Augustine volcano (thesis) V,Ps Barrett others 1977 Model of Augustine volcano [abs.] [as Beget 1986 prehistoric tephra at Augustine [abs.] V,Gs Daley 1986 petro, geochem \& evol magmas Augustine (thesis) PG Daley \& Swanson 1985 Low press fractionation Augustine [abs.] PG Davidson 1884 Notes volc eruption Augustine

Davies \& Kienle 1986 Augustine eruption \& advice [abs.]

Decker 1967 Invest at active volcanoes

Detterman 1968 Volcanic activity Augustine Island

Detterman 1973 Geol map Il iamna B-2 Quad Augustine Island $\mathrm{H}, \mathrm{V}$

Detterman \& Reed 1964 Prelim geol map Iliamna Q $\mathrm{V}, \mathrm{C}$ 
Detterman \& Reed 1968 Geol Illamna $Q \quad$ Gr

Detterman \& Reed 1973 Surficial deposits Iliamna $Q$ Gr

Detterman \& Reed 1980 strat, struct, \& econ geol Illamna $Q$ Gr

Estes 1978 seismotectonic studies lower Cook Inlet (thesis) Pr

Forbes \& Rienle 1971 Augustine

Forbes \& others 1971 Selsmicity Augustine [abs.]

Gosink \& others 1986 Augustine ash [abs.]

Harmon \& others 1982 Isotopes from Augustine fumaroles

Harmon \& others 1984 Augustine chem \& 1sot character [abs.]

Hobbs \& others 1977 Eruption of Augustine

Johnson 1976 zoned magma chamber Augustine [abs.]

Johnson 1978 Magma mixing Augustine volcano (thesis)

Johnson 1978 Magma mixing Augustine volcano [abs.]

Ps, V

Johnson 1979 Volc gas studies Ak volcanoes

Johnson 1979 Volcanism at Augustine

Johnson 1980 Volc contr Cl to stratosphere

$\mathrm{V}$

Ff

PG

Johnson \& Detterman 1979 Revision of eruptive history Augustine $V$ Johnson \& others 1977 Augustine Volc, evaluat hazards [abs.] V, Eg

Kienle 1972 Volc micro-quakes Augustine [abs.]

Kienle 1974 Alaskan volcano studies esp. Augustine

Kienle 1986 Augustine Volcano [abs.]

Kienle \& Forbes 1974 Ak volc studies Augustine

* Kienle \& Forbes 1977 Augustine - Evolution of volcano

*. Kienle \&ulpan 1975 Tide caused quakes at Augustine [abs.] Ps,V

Kienle \& Shaw 1977 Augustine erupt - initlal phase 1976

Kienle \& Swanson 1980 Volcanic hazards Augustine

Rienle \& Swanson 1983 Volc E Aleut arc I Quat \& Holo cntrs

Rienle \& Swanson 1983 Volc $\mathbf{E}$ Aleut arc Quat \& Holo centers

Rienle \& Swanson 1985 Volc hazards Augustine 2nd ed.

Kienle \& others 1971 Microquake swarm Augustine [abs.]

Rienle others 1979 Shallow magma at Augustine

Rienle \& others 1986 Augustine \& tsunamis [abs.]

Kodosky \& Keskinen 1986 Fumarole alt Augustine [abs.]

$\mathrm{V}, \mathrm{Ps}$

Lalla 1987 Seismo thermal studies Augustine (thesis)

Ialla \& Kienle 1974 Infrared thermometry Augustine [abs.]

Ialla \& Kienle 1976 Thermal studies Augustine [abs.]

Ialla \& Kienle 1978 Evolution seismicity Augustine [abs.]

Ialla \& Kienle 1980 Problems volc selsmo Augustine [abs.]

Ialla \& Kienle 1986 Sels therm precursors erupt Augustine $V, P s, H S$

Iimke \& Beget 1986 Pyroclastic flows Augustine [abs.]

Markle 1979 Geotherm Ak site data base \& devel status R,Fs,Gr,C

Martin \& Katz $1910 \mathrm{Geol}$ \& min resources Iliamna \& Iake Clark $\mathrm{H}, \mathrm{Gr}$

Martin \& Ratz 1912 Geol recon Iliamna Region

Mauk \& Kienle 1973 Microquake Augustine earthtides

Metzner 1975 Magnetoteliuric invest. Augustine Ps,V

Miller 1976 Augustine volcano

Motyka \& others 1983 Geothermal resources of Alaska R,Fs,Ff,Fw

Motyka o others 1986 Augustine gas sampling [abs.] Ff

Pearson 1977 Selsmic refr Augustine (thesis) V,Ps

Pearson \& Rienle 1978 Selsmic refr study Augustine [abs.] V,Ps

Poreda o others 1981 He isot vars Ak-Aleut arc [abs.] R,Fs,Ff

Prosser 1912 Volcanic road-building

Reeder \& others 1977 Selsm Augustine volc [abs.]

Riehle 1985 . Recon Holo tephra deposits upper cook Inlet

$\mathrm{H}, \mathrm{V}$

$\mathrm{V}, \mathrm{Ps}$ 
Schmincke Johnson 1977 Pyroclastic flows Augustine [abs] Schnell Sheridan 1986 Arctic gas aerosols-Augustine [abs.] V Siebert others 2986 , Debris avalanches Augustine [abs.] V Stith others 1977 Nuee ardent Augustine volc V Swanson \& others 1986 Magmatic evolution Augustine [abs.] PG,V Viglino \& others 1985 Isot evid magma comp in fum cond Augst $V, F f$ White \& Williams 1975 Assmt geothermal resources US R,Fs, HS Wilson \& Kienle 1976 Infrasonic signals Augustine volc [abs.] V

Ba1ley Bay SE-17

Baker \& others 1977 Geotherm springs-salmon hatchery site R,DP,Fs Berg \& others 1978 Geol map Retchikan \& Prince Rupert Q Ak. Gr Berry \& others 1980 Thermal spring list U.S. Brook \& others 1979 Hydrothermal systems <90 deg Budalngton \& Chapin 1929 Geol \& mineral deposits SE Ak Forbes \& others 1975 Utilization geothermal rural Ak R, FS Markle 1979 Geotherm Ak site data base \& devel status R,Fs,Gr,C Miller 1973 Distribution chem analysis thermal springs Ak R,Fs Motyka Moorman 1980 Assmt thermal spring S SE AK [abs.] R,Fs Motyka \& Moorman 1987 Geotherm resourcers SE Ak R,Fs, FW Motyka \& others 1980 Assmt therm spr S SE AK Motyka o others 1983 Geothermal resources of Alaska R,Fs,Ff,Fw Muffler 1979 Assmt geothermal resources U. S. Nava 1975 Note on hot springs SE AK Ogle 1976 Ak. hot spring site for small binary plant sloan 1976 Chem anal Bailey Bay HS Turner \& others 1980 Geothermal resources Alaska Waring 1917 Mineral springs Ak Waring 1965 Thermal springs US \& world - a summary White \& WIIlams 1975 Assmt geothermal resources US Wright 1906 Nonmetallic deposits SE Ak. Wright \& Wright 1908 Ketchikan \& Wrangell mining districts $\mathrm{Gr}, \mathrm{H}$

Baker Island $\cdots+S E-I I$

Berry others 1980 Thermal spring 1ist U.S. Bliss 1983 Ak baslc data thermal springs \& wells R, Fs, Fw Buddington \& Chapin 1929 Geol \& mineral deposits SE Ak Gr Eberlein \& others 1983 Geol map Cralg Q Gr Kase 1986 Trocadero soda springs Markle 1979 Geotherm Ak site data base \& devel status R,Fs,Gr,C Motyka Moorman 1980 Assmt thermal spring S SE Ak [abs.] R, Fs Motyka Moorman 1987 Geotherm resourcers SE Ak Motyka \& others 1983 Geothermal resources of Alaska Reed \& others 1983 Data low temp geothermal systems US Turner \& others 1980 Geothermal resources Alaska R, Fs, FW R,Fs, FE, FW HS , R, Fs R,Fs

Baranof $S E-10$

Berg \& Hinckley 1963 Recon geol northern Baranof Is. Berry \& others 1980 Thermal spring 1ist U.S. BIIss 1983 Ak basic data thermal springs wells Buddington \& Chapin 1929 Geol mineral deposits SE Ak 
Knopf 1912 sitka mining district

Loney others 1964 Recon geol map Baranof Kruzof Is

Loney \& others 1967 Radio ages \& fault movements $N$ SE AK

Loney \& others 1975 Recon geol Chichagof, Baranof \& Kruzof Is Gr Markle 1979 Geotherm Ak site data base devel status R,Fs,Gr,C Miller 1973 Distribution \& chem analysis thermal springs Ak R, Fs Motyka \& Moorman 1987 Geotherm resourcers SE Ak Motyka \& others 1983 Geothermal resources of Alaska Nava 1975 Note on hot springs SE Ak

Reed \& others 1983 Data low temp geothermal systems Us Rosenthal 1908 Hot springs of southeast Alaska Turner \& others 1980 Geothermal resources Alaska Twenhofel \& Sainsbury 1958 Fault patterns SE Ak Waring 1917 Kineral springs Ak Waring 1965 Thermal springs Us \& world - a summary White \& Williams 1975 Assmt geothermal resources US Wright 1906 Nonmetallic deposits SE Ak. R,Fs, Fw $R, F s, F f, F w$ R, Fs HS, R, Fs $\mathbf{H}, \mathbf{R}$ R,Fs Gr Fs, $R$ Fs $R, F s, H S$ Gr, H

Barnes Lake SE-15

Berry \& others 1980 Thermal spring list U.S. Bliss 1983 Ak basic data thermal springs \& wells Buddington \& Chapin 1929 Geol mineral deposits SE Ak Kerr 1948 stikine \& Iskut River area BC, Canada Markle 1979 Geotherm Ak site data base devel status $R$ Fs, Gr Motyka \& Moorman 1980 Assmt thermal spring $S$ SE Ak [abs.] R, Fs Motyka \& Moorman 1987 Geotherm resourcers SE Ak Motyka \& others 1980 Assmt therm spr S SE Ak Motyka \& others 1983 Geothermal resources of Alaska Turner \& others 1980 Geothermal resources Alaska Wright \& Wright 1908 Ketchikan \& Wrangell mining districts

Battleship NC-5

Bliss 1983 Ak basic data thermal springs \& wells Hudson 1977 Geol map Seward Penin Markle 1979 Geotherm Ak site data base \& devel status $R, F \mathbf{F}, \mathbf{G r}, C$ Miller $1972 \mathrm{~K}$ rich intrusive rocks $\mathrm{W} \mathrm{Ak}$ R, FS, FW R, Fs $R, F s, F f, F w$ R,Fs Miller 1973 Distribution chem analysis thermal springs Ak $R$, Fs Miller \& others 1972 Prelim geol map Solomon \& SE Bendeleben $Q$ Gr Miller \& others 1975 Geol \& chem hot springs W cent Ak Motyka \& others 1983 Geothermal resources of Alaska Reed \& others 1983 Data low temp geothermal systems Us Robinson stevens 1983 Geol map Seward Penin Robinson \& stevens 1984 Geol map seward Penin Turner \& others 1980 Geothermal resources Alaska Gr, H

Baker others 1977 Geotherm springs-salmon hatchery site R,DP, Fs Berg \& others 1978 Geol map Retchikan \& Prince Rupert $Q$ Ak. Berry \& others 1980 Thermal spring list U.S. Brook \& others 1979 Hydrothermal systems $<90$ deg

Buddington \& Chapin 1929 Geol mineral deposits SE Ak

\section{Bell Island SE-18}


Markle 1979 Geotherm Ak site data base \& devel status R,Fs,Gr,C Milier 1973 Distribution chem analysis thermal springs Ak R, Fs Motyka \& Moorman 1980 Assmt thermal spring S SE Ak [abs.] R, Fs Motyka \& Moorman 1987 Geotherm resourcers SE Ak R,Fs,FW Motyka \& others 1980 Assmt therm spr S SE Ak Motyka \& others 1983 Geothermal resources of Alaska Muffler 1979 Assmt geothermal resources U. S. Nava 1975 Note on hot springs SE Ak ogle 1976 Ak. hot spring site for small binary plant sloan 1976 Chem anal Bell Is HS Turner \& others 1980 Geothermal resources Alaska Waring 1917 Mineral springs Ak Waring 1965 Thermal springs US \& world - a summary White \& Williams 1975 Assmt geothermal resources US Wright 1906 Nonmetallic deposits SE Ak. R,Fs Wright \& Wright 1908 Ketchikan \& Wrangell mining districts Gr,

Big Windy NC-34

Berry \& others 1980 Thermal spring list U.S.

Foster \& others 1970 Geol Yukon-Tanana upland [abs.] Gr

Foster \& others 1973 Geology Yukon-Tanana upland Gr

Foster \& others 1983 Geologic map CIrcle Q Gr Gr

Foster others 1983 Prelim geol map Circle Quad Gr Gassaway \& Abramson 1977 Map \& table thermal springs cntr Ak R,Fs Kelth \& Foster 1979 Big Windy Creek HS Fs Kelth others 1981 Chem \& lsot data Big windy creek HS Fs Markle 1979 Geotherm Ak site data base \& devel status R,Fs,Gr,C Menzle \& others 1983 Mineral assmt circle Quad Gr Mertie 1930 Geology Eagle-circle district Gr Miller 1973 Distribution \& Chem analysis thermal springs AK R,Fs Motyka \& others 1983 Geothermal resources of Alaska R, Fs, Ff, FW Nava \& Morrison 1974 Note on hot springs interior Ak R,Fs Turner \& others 1980 Geothermal resources Alaska R,Fs Waring 1917 Mineral springs Ak Waring 1965 Thermal springs US \& world - a summary Fs W1lson \& Shew 1981 prelim K-Ar studies circle $Q \quad$ Gr

Bogoslof AA-39

Berry \& others 1980 Thermal spring list U.S. R $R$ Brown 1899 Shishaldin $\quad$ H Byers 1959 Geol Umnak \& Bogoslof Islands Gr Byers 1961 Petro 3 volc suites Umnak \& Bogoslof Islands PG Dall 1870 Bogosloff volcano

Dall 1884 New volcano 1sland

Dall 1889 Notes on Bogoslof 1sland

Davidson 1884 New Bogoslof volcano

Davidson 1884 New volcano in Alaska

Diller 1893 our youngest volcano

Jaggar 1908 Evolution Bogoslof Volcano

Jaggar 1908 Evolution of Bogoslof [abs.]

Merriam 1901 Birth of Bogosiof

Merrill 1885 Hornblende andesites from Bogosloff

$\mathrm{H}, \mathrm{V}$

$\mathrm{H}, \mathrm{V}$

$\mathrm{H}, \mathrm{V}$

$\mathrm{H}, \mathrm{V}$

$\mathbf{H}, \mathbf{V}$

$\mathrm{H}$

$\mathrm{V}, \mathrm{H}$

$\mathrm{H}, \mathrm{V}$

$\mathrm{H}, \mathrm{V}$

H, Gs, PG 
Merriman 1910 Bogoslof new volcano V Miller 1973 Distribution \& chem analysis thermal springs Ak R,Fs Motyka \& others 1981 Assmt thermal spring Aleutian arc R,Fs,Ff, Gr Powers 1916 Changes in Bogoslof volc

-Prosser 1912 Volcanic road-building

stoney 1884 Volcano in Bering Sea

istoney 1900 Naval expl Alaska

Turner \& others 1980 Geothermal resources Alaska

Waring 1917 Mineral springs Ak

Waring 1965 Thermal springs US \& world - a summary

White \& Williams 1975 Assmt geothermal resources US

$\mathrm{H}, \mathrm{V}$

$\mathrm{H}, \mathrm{V}$

$\mathrm{H}, \mathrm{V}$

$\mathrm{H}, \mathrm{Gr}$

R, Fs

Fs, R

R,Fs, FS

\section{Bradfield Canal SE-16}

Bliss 1983 Ak basic data thermal springs \& wells R,Fs,Fw Markle 1979 Geotherm Ak site data base devel status R,FG,Gr,C Miller 1973 Distribution c chem analysis thermal springs Ak R,Fs Motyka \& Moorman 1980 Assmt thermal spring S SE Ak [abs.] R, Fs Motyka \& Moorman 1987 Geotherm resourcers SE Ak R,Fs, Fw Motyka \& others 1980 Assmt therm spr S SE AK Motyka \& others 1983 Geothermal resources of Alaska R,Fs,Ff,FW Peale 1886 Mineral springs of US Turner \& others 1980 Geothermal resources Alaska Wright 1906 Nonmetallic deposits SE Ak. Wright \& Wright 1908 Ketchikan \& Wrangell mining districts R,Fs $\mathrm{H}, \mathbf{R}$ R, Fs $\mathrm{Gr}, \mathrm{H}$ Gr, H

Cheeneetnuk sc-23

Blodgett \& Gilbert 1983 Cheeneetnuk Iimestone Mc Grath

Bundtzen \& Gilbert 1983 Geology upper Kuskokwim

Bundtzen \& Kline 1986 Coal, peat \& geotherm in Kuskokwim Cady \& others 1955 Geology central Kuskokwim

Decker 1984 Kuskokwim group

Decker \& Hoare 1982 Cretaceous Kuskokwim Group

Dickey 1983 Tertiary seds \& tectonics Farewell fault area Gs,PG Dickey \& others 1982 Cenozoic seds \& Farewell fault

Gilbert 1981 Geologic map Cheeneetnuk River area

Chena NC-32

Berry \& others 1980 Thermal spring list U.S.

Biggar 1974 Geol \& geophys stdy at Chena HS (thesis) Gs, Ps,Fs, Fw

Bliss 1983 Ak basic data thermal springs \& wells R,Fs,Fw

Brook \& others 1979 Hydrothermal systems $<90$ deg

* Forbes \& Biggar 1973 Ak geothermal resource potential

Forbes \& others 1975 Utilization geothermal rural Ak

Foster \& others 1970 Geol Yukon-Tanana upland [abs.]

R, Fs

$R$, HS

Foster \& others 1973 Geology Yukon-Tanana upland

Foster \& others 1983 Geologic map Circle $Q$

Foster \& others 1983 Prelim geol map Circle Quad

Fs, DP, Ef

Gr

Gr

Gr

Gassaway \& Abramson 1977 Kap \& table thermal Markl Markle 1979 Geotherm Ak site data base \& devel status R,Fs,Gr,C Menzie others 1983 Mineral assmt Circle Quad Gr Millex 1973 Distribution \& chem analysis thermal springs Ak R,Fs 
Motyka \& others -1983 Geothermal resources of Alaska Muffler 1979 Assmt geothermal resources U. $\mathrm{s}$. Reed \& others 1983 Data low temp geothermal systems us Reeder \& others $1980 \mathrm{Ak}$. géothermal program Turner \& others 1980 Geothermal resources Alaska Waring 1917 Mineral springs Ak Waring 1965 Thermal springs US \& world - a summary Wescott 1981 He \& Hg surveys Chena HS Wescott \& Turner 1981 Geol geophys Chena HS White \& Willams 1975 Assmt geothermal resources us Wilson \& Shew 1981 Prelim K-Ar studies Circle $Q$

$$
\begin{array}{r}
R, F s, F f, F w \\
R, F s, H S \\
H S, R, F s \\
D P \\
R, F s \\
F s, R \\
F s \\
\text { GC } \\
*, G s, P s, G C \\
R, F s, H S
\end{array}
$$

Chief shakes $S E-14$

Berry \& others 1980 Thermal spring 11st U.S.

BIIss $1983 \mathrm{Ak}$ basic data thermal springs \& wells $\mathrm{R}, \mathrm{Fs}, \mathrm{FW}$ Brew others 1984 Geologic map Peterbrg, Sumdum, P. Alex Gr Brook \& others 1979 Hydrothermal systems <90 deg R, Fs Buddington \& Chapin 1929 Geol \& mineral deposits SE AK Gr Kerr 1948 stikine \& Iskut River area BC, Canada Gr Markle 1979 Geotherm Ak site data base \& devel status R,Fr, Gr,C Miler 1973 Distribution chem analysis thermal springs Ak R,Fs Motyka \& Moorman 1980 Assmt thermal spring $S$ SE Ak [abs.] R,FG Motyka \& Moorman 1987 Geotherm resourcers SE Ak R, Fs, Fw Motyka \& others 1980 Assmt therm spr S SE Ak Motyka \& others 1983 Geothermal resources of Alaska Muffler 1979 Assmt geothermal resources U. S. Ogle 1976 Ak. hot spring site for small binary plant Rosenbruch \& Bottge 1975 Econ potent 3 sites Ak Sloan 1976 Chem anal Chief Shakes HS R,Fs Turner \& others 1980 Geothermal resources Alaska Waring 1917 Mineral springs Ak Waring 1965 Thermal springs US \& world - a summary White \& W11Ilams 1975 Assmt geothermal resources US $R, F s, F f, F w$ R, Fs, HS R, DP, Fs EF Fs Wright \& Wright 1908 Ketchikan \& Wrangell mining districts

\section{Chiginagak AA-36}

Detterman \& others 1983 Geol map Ugashik-Bristol Bay-Karluk $Q$ Gr Detterman \& others 1985 Geol map Ugashik \& Karluk $Q$ Gr Detterman \& others 1986 Quat map Ugashik-Bristol Bay-Karluk Q Gr Lecompte 1981 Prelim map Landsat Ugashik \& Karluk Q Miller \& Barnes 1974 Geotherm devel Ak [abs.] Gr Miller \& Barnes 1976 Geotherm develop Ak summary Motyka \& others 1983 Geothermal resources of Alaska Smith \& Baker 1924 Cold Bay-Chignik dist

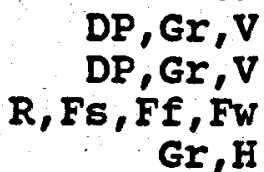

$D P, G r, V$ $D P, G r, V$ Gr, H

Chuginadak $\quad A A-10$

Berry \& others 1980 Thermal spring list U.S.

$R$

Markle 1979 Geotherm Ak site data base devel status R,Fs,Gr,C Miller 1973 Distribution \& chem analysis thermal springs Ak R,Fs Motyka others 1981 Assmt thermal spring Aleutian arc R,Fs,Ff,Gr Motyka others 1983 Geothermal resources of Alaska R,Fs,Ff,Fw 
Turner \& others 1980 Geothermal resources Alaska

Waring 1965 Thermal springs US \& world - a summary

White \& Willams 1975 Assmt geothermal resources US

$$
\begin{array}{r}
R, F s \\
\text { Fs } \\
R, F s, F S
\end{array}
$$

Chuilnuk $\quad S C-2$

Anonymous 1975 Ak regional profiles sW region

Berry \& others 1980 Thermal spring 11st U.S.

Collazz1 \& Ireland 1986 Hydrology lower Kuskokwim basin

Decker \& Hoare 1982 Cretaceous Ruskokwim Group

Decker \& others 1984 Geology Sleetmute B-5 Quad

Gassaway \& Abramson $1977 \mathrm{Map}$ \& table thermal springs ontr $A k$ R $F$ Milier 1973 Distribution \& chem analysis thermal springs Ak R, Fs

* Motyka \& others 1983 Geothermal resources of Alaska R,Fs, Ff, Fw Robinson \& Decker 1986 Ages \& analysis from SW Alaska Gr,PG Robinson \& others 1984 Bdrck geol Chuilnuk \& Kiokluk Mts [abs] Gr Robinson \& others 1984 Geologic map sleetmute B-5 $Q$ Gr Robinson \& others 1986 Rocks from sleetmute, Russian Mission Q PG

Circle $\quad \mathrm{NC}-33$

Berry \& others 1980 Thermal spring list U.s.

Gr

Gs

Gr Bliss 1983 Ak basic data thermal springs \& wells

Brook \& others 1979 Hydrothermal systems <90 deg

Forbes \& Biggar 1973 Ak geothermal resource potential

Forbes \& others 1975 Utilization geothermal rural Ak

Foster \& others 1970 Geol Yukon-Tanana upland [abs.]

Foster \& others 1973 Geology Yukon-Tanana upland

Foster \& others 1983 Geologic map circle Q

Foster \& others 1983 Prelim geol map Circle Quad

Gassaway \& Abramson 1977 Map \& table thermal springs cntr AK R, Fs Markle 1979 Geotherm Ak site data base \& devel status R,Fs,Gr,C Menzie \& others 1983 Mineral assmt Circle Quad

Mertie 1930 Geology Eagle-circle district

$R, F s, F w$

R,Fs

$R$, IS

FG, DP, Ef

Gr

Gr

$\mathbf{G r}$

Gr

Miler 1973 Distribution \& chem analysis thermal springs Ak R, Fs

Motyka \& others 1983 Geothermal resources of Alaska R,Fs,Ff, Fw

Muffler 1979 Assmt geothermal resources $U$. S.

Nehring \& others 1979 Sulfate geotherm western U. S.

Ogle $1976 \mathrm{Ak}$. hot spring site for small binary plant

Reeder \& others 1980 Ak. geothermal program

Turner \& others 1980 Geothermal resources Alaska

Waring 1917 Mineral springs Ak

Waring 1965 Thermal springs Us \& world - a summary

White \& Williams 1975 Assmt geothermal resources US

Wilson \& Shew 1981 Prelim K-Är studies Circle Q

wiltse 1986 Radon hazard assessment circle HS

R, Fs, HS

R, Fs

$R, D P, F s$

DP

R, Fs

Fs, R

Fs

R, Fs, HS

Gr

GC

\section{Clear Creek NC-7}

Berry \& others 1980 Thermal spring list U.S. Bliss 1983 Ak basic data thermal springs \& wells

Brook \& others 1979 Hydrothermal systems $<90$ deg

Forbes \& others 1975 Utilization geothermal rural Ak

Forbes \& others 1975 Ut, DP

Forbes \& others 1975 Utilization of Alaska thermal springs DP 
Hudson 1977 Geol map Seward Penln

Markle 1979 Geotherm Ak site data base \& devel status R,Fs,Gr,C Miller $1972 \mathrm{~K}$ rich intrusive rocks W Ak

Miller 1973 Distribution \& chem analyisis thermal springs Ak R, Fs Miller \& others 1972 Prelim geol map Solomon \& SE Bendeleben $Q$ Gr Miller others 1975 Geol chem hot springs W cent Ak R, Fs Motyka others 1983 Geothermal resources of Alaska R,Fs,Ff, FW Muffler 1979 Assmt geothermal resources U. $S$. Ogle 1976 Ak. hot spring site for small binary plant R,DP,Fs Reeder others 1980 Ak. geothermal program Robinson \& Stevens 1983 Geol map Seward Penin Robinson \& Stevens 1984 Geol map Seward Penin White \& Williams 1975 Assmt geothermal resources US $R, F s, H S$
$R, D P, F S$ DP Gr Gr Cold Bay AA-28

Berry \& others 1980 Thermal spring list U.S. Bliss 1983 Ak basic data thermal springs \& wells Brook \& others 1979 Hydrothermal systems <90 deg Brophy \& Marsh 1984 petro \& geochem Cold Bay volc [abs.] PG Funk 1973 Late Quat geol cold Bay (thesis) Funk 1973 Late Quat hist Cold Bay [abs.] Miller 1973 Distribution \& chem analysis thermal springs Ak R,Fs Motyka \& Moorman 1981 Recon thermal spr Aleutian arc R,Fs,Ff Motyka \& others 1981 Assmt thermal spring Aleutian arc R,Fs,Ff,Gr Motyka \& others 1983 Geothermal resources of Alaska R, Fs, Ff, FW Muffler 1979 Assmt geothermal resources U. S. Turner \& others 1980 Geothermal resources Alaska Waldron 1961 Geol recon Frosty Peak volc White \& williams 1975 Assmt geothermal resources US

$$
\begin{array}{r}
R, F S, H S \\
R, F S \\
\text { Gr } \\
R, F S, H S
\end{array}
$$

Copper Glacier sc-19

Henning \& others 1981 wrangell-st Elias wilderness Mendenhall 1903 Mineral resources Mt wrangell district $H, G r$ Motyka others 1983 Geothermal resources of Alaska R,Fs, Ff, FW Richter 1975 Geol map Nabesna $Q$ Richter 1976 Geol map Nabesna Q Turner \& others 1980 Geothermal resources Alaska

$$
\begin{array}{r}
G r \\
G r \\
R, F s
\end{array}
$$

Dall NC-10

Berry \& others 1980 Thermal spring list U.S. R Brosge \& Patton 1982 Bedrock geol maps Dalton Hwy Gr Dixon \& Pulpan 1986 Crustal structure-Dall City [abs.] Ps Gassaway \& Abramson 1977 Map \& table thermal springs cntr Ak R,Fs Markle 1979 Geotherm Ak site data base devel status R,Fs,Gr,C Miller 1973 Distribution \& chem analysis thermal springs AK R, Fs Miller \& others 1975 Geol \& chem hot springs $W$ cent Ak R, Fs Motyka \& others 1983 Geothermal resources of Alaska R, Fs, Ff, FW Nava \& Morrison 1974 Note on hot springs interior Ak R, Fs Turner \& others 1980 Geothermal resources Alaska R,Fs 
Dulbai NC-13

Berry \& others 1980 Thermal spring Iist U.S. BIIss $1983 \mathrm{Ak}$ basic data thermal springs wells Brook \& others 1979 Hydrothermal systems $<90$ deg Cass 1959 Recon geol map Melozitna $Q$ Ak. $R, F \in, F w$ R, Fs (9) Markle 1979 Geotherm Ak site data base devel status R,Fs,Gr,C Milier 1973 Distribution chem analysis thermal springs Ak R, Fs Milier \& others 1975 Geol \& chem hot springs $W$ cent Ak R,Fs Motyka \& others 1983 Geothermal resources of Alaska R,Fs,Ff,Fw Muffler 1979 Assmt geothermal resources $U$. $S$. $R, F s$, HS

Patton \& others 1978 Geol map Melozitna Q Silberman \& others 1978 Age of rocks Ruby, Medfra \& adj $Q$ Gr Turner \& others 1980 Geothermal resources Alaska R,Fs

\section{Edgecumbe}

$S E-19$

Brew \& others 1965 Eruptive history Mt. Edgecumbe [abs.] V Brew others 1969 Recon geol Mt Edgecumbe

Kosco 1981 Edgecumbe volc \& Katmal (thesis)

Myers 1978 Petro \& petrogenesis Edgecumbe volc [abs.] Myers 1979 Geol, petro Edgecumbe: trnsfrm fault volc (thesis) PG Myers \& Marsh 1981 Geol \& petrogen Edgecumbe volcanics PG Myers \& others 1984 Assim crust by basalt magma Edgecumbe PG smith \& Shaw 1979 Igneous related geothermal systems $R$,HS White \& Williams 1975 Assmt geothermal resources US R,Fs,HS White \& Williams 1975 Assmt geothermal resources US R,Fs,HS Workman 1979 signif volc in prehist of subarctic

Egg Island $\quad A A-27$

Bliss $1983 \mathrm{Ak}$ basic data thermal springs \& wells R,Fs,Fw Coats 1956 Recon geol W Aleutian Islands $\mathrm{Gr}$ Miller 1973 Distribution chem analysis thermal springs Ak R,Fs Motyka \& Moorman 1981 Recon thermal spr Aleutian arc R,Fs,Ff Motyka \& others 1981 Assmt thermal spring Aleutian arc R,Fs,Ff, Gr Motyka \& others 1983 Geothermal resources of Alaska R, Fs, Ff, Fw Peale 1886 Mineral springs of US Turner \& others 1980 Geothermal resources Alaska Waldron 1961 Geol recon Frosty Peak volc $\mathrm{H}, \mathrm{R}$ R, Fs Gr

Emmons Lake AA-29

Berry \& others 1980 Thermal spring 11st U.S. R Rennedy \& Waldron 1955 Geol Pavlof volcano Gr Miller 1973 Distribution \& chem analysis thermal springs Ak R,Fs Miller \& Barnes 1974 Geotherm devel Ak [abs.] Miller \& Barnes 1976 Geotherm develop Ak summary Motyka $1983 \mathrm{High}$ temp hydrothermal resources Aleut arc Motyka \& Moorman 1981 Recon thermal spr Aleutian arc Motyka \& others 1981 Assmt thermal spring Aleutian arc R,Fs,Ff,Gr Motyka \& others 1981 Assmt thermal spring Aleutian arc R,Fs,Ff, Gr
Motyka \& others 1983 Geothermal resources of Alaska R,Fs,Ff,Fw Reeder \& others $1980 \mathrm{Ak}$. geothermal program $\mathrm{DP}, \mathrm{Gr}, \mathrm{V}$ $D P, G r, V$ R,FE,Ff $R, F s, F f$ 
Smith \& Shaw 1979 Igneous related geothermal systems Turner \& others 1980 Geothermal resources Alaska White \& W111ams 1975 Assmt geothermal resources US

\author{
$R$, HS \\ R, Fs \\ $R, F s, H S$
}

False Pass AA-25

Baker \& others 1977 Geotherm springs-salmon hatchery site R,DP,Fs Markle 1979 Geotherm Ak site data base \& devel status R,FG,Gr,C Motyka \& Moorman 1981 Recon thermal spr Aleutian arc R,Fs,Ff Motyka \& others 1981 Assmt thermal spring Aleutian arc R,Fs,Ff, Gr Motyka \& others 1983 Geothermal resources of Alaska R,Fs,Ff, Fw Turner others 1980 Geothermal resources Alaska R, Fs

Fish Bay SE-8

Berg Hinckley 1963 Recon geol northern Baranof Is. Berry others 1980 Thermal spring 11st U.S. Brook \& others 1979 Hydrothermal systems <90 deg Buddington \& Chapin 1929 Geol \& mineral deposits SE AK Knopf 1912 sitka mining district Loney \& others 1963 Recon geol map Chichagof \& NW Baranof Is Gr Loney others 1964 Recon geol map Baranof \& Kruzof Is Gr Ioney \& others 1967 Radio ages \& fault movements $N$ SE AK Gr Ioney \& others 1975 Recon geol Chichagof, Baranof \& Kruzof Is Gr Markle 1979 Geotherm Ak site data base \& devel status R,Fs,Gr,C Miller 1973 Distribution chem analysis thermal springs Ak R, Fs Motyka \& Moorman 1987 Geotherm resourcers SE Ak Motyka \& others 1983 Geothermal resources of Alaska Muffler 1979 Assmt geothermal resources U. $S$. Nava 1975 Note on hot springs SE AK Rossman 1959 Geol ore dep NW Chichagof Is Turner \& others 1980 Geothermal resources Alaska Twenhofel \& Sainsbury 1958 Fault patterns SE Ak Waring 1917 Mineral springs AK Waring 1965 Thermal springs Us \& world - a summary White \& Willams 1975 Assmt geothermal resources US

$$
\begin{array}{r}
R, F s, F w \\
R, F s, F f, F w \\
R, F s, H S \\
R, F s \\
\text { Gr } \\
R, F s \\
\text { Gr } \\
F s, R \\
F s \\
R, F s, H S
\end{array}
$$

Gas Rocks AA-38

Berry \& others 1980 Thermal spring list U.S $R$ Detterman \& others 1983 Geol map Ugashik-Bristol Bay-Karluk Q $\mathrm{Gr}$ Detterman \& others 1985 Geol map Ugashik \& Karluk $Q$ Kr Detterman \& others 1986 Quat map Ugashik-Bristol Bay-Rarluk Q Gr Lecompte 1981 Prelim map Landsat Ugashik \& Karluk Q Markle 1979 Geotherm Ak site data base \& devel status R,Fs,Gr,C M1IIer 19842 stage volcanism Ugashik-Peulik [abs.] PG Motyka others 1981 Assmt thermal spring Aleutian arc $R, F s, F f, G r$ Motyka \& others 1983 Geothermal resources of Alaska R,Fs,Ff,Fw Reed \& others 1983 Data low temp geothermal systems US HS,R,Fs Smith 1925 Cold Bay Ratmal dist

Smith \& Baker 1924 Cold Bay-Chignik dist Turner \& others 1980 Geothermal resources Alaska Waring 1917 Mineral springs Ak Waring 1965 Thermal springs US \& world - a summary $\mathbf{G r}, \mathrm{H}$ Gr, H R,Fs Fs, R Fs 
Geyser Bight AA-12

Berry others 1980 Thermal spring list U.S. R

Black 1974 Geol anclent Aleuts : Gr

Black 1974 Late Quat sea level changes Umnak Is Gr

Black 1975 Late Quat geomorph Umnak Is Gr

Black 1976 Geol Umnak related to Aleuts

Bliss 1983 Ak basic data thermal springs \& wells

Gr

Brook \& others 1979 Hydrothermal systems $<90$ deg

R,Fs, FW

Byers 1959 Geol Umnak \& Bogoslof Islands

Byers 1961 Petro 3 volc suites Umnak \& Bogoslof Islands

Byers \& Brannock 1949 Volc activity Umak \& Great Sitkin Is

coats 1956 Recon geol $\mathrm{W}$ Aleutian Islands

R, Fs

Gr

PG

Forbes \& Biggar 1973 Ak geothermal resource potential

Gr

1979 Geotherm Ak site data base \& deved Markle 1979 Geotherm Ak site data base \& devel status $R, F s, G r, C$ Miller 1973 Distribution \& chem analysis thermal springs Ak R,Fs Miller \& Barnes 1974 Geotherm devel Ak [abs.]

Miller \& Barnes 1976 Geotherm develop AK summary

Motyka $1983 \mathrm{High}$ temp hydrothermal resources Aleut arc

- Motyka \& Moorman 1981 Recon thermal spr Aleutian arc

Motyka \& others 1981 Assmt thermal spring Aleutian arc

Motyka \& others 1983 Geothermal resources of Alaska

Muffler 1979 Assmt geothermal resources U. S.

Nehring \& others 1979 Sulfate geotherm western U. S.

Ogle $1976 \mathrm{Ak}$. hot spring site for small binary plant

Petrov 1884 Alaska population \& resources

Reeder \& others 1980 Alk. geothermal program

Turner \& others 1980 Geothermal resources Alaska

Waring 1965 Thermal springs US \& world - a summary

White \& Williams 1975 Assmt geothermal resources US

$D P, G r, V$

$D P, G r, V$

$R, F s, F f$

R,Fs, Ff

$R, F G, F f, G r$

$R, F \mathbf{F}, F, F W$

R, FS, HS

R,Fs

$R, D P, F s$

$\mathrm{H}, \mathrm{C}$

DP

R, Fs

Fs

R,Fs, HS

\section{Glacier Valley AA-17}

Arce 1983 Volcanic hazards Makushin Volcano (thesis) Eg

Arce \& Economides 1982 Volcanic hazards Makushin Volcano Eg

Boyd \& Jacob 1984 Seismicity of Unalaska Pr

Carey \& others 1983 Unalaska geotherm land, regs, \& environ DP Corwin \& Fitterman 1983 Self potential Kakushin geotherm area Ps

Denig-Chakroff 1985 Unalaska recon study

Drewes \& others 1961 Geol Unalaska \& adjacent shelf

Economides \& others 1981 Unalaska geothermal development DP

*conomides \& others 1982 Eng,geol anal geothermal sites EF,Er

Economides \& others 1985 Eval Makushin geothermal reservoir Er

Isselhardt others 1983 Geotherm resource model Makushin RM, HS

Isselhardt others 1983 Temp grads Makushin geothermal area HS

Jacob \& Boyd 1985 selsmic network on Unalaska Pr

Martin 1917 Mineral resources of Ak.

Matlick \& Parmentier $1983 \mathrm{Hg}$ soll survey Makushin

$\mathrm{H}, \mathrm{Gr}$

Morrison-Knudson Co. 1981 Geotherm potential Aleut Unalaska $R$

Motyka 1982 Fluid geochem Makushin \& Akutan geotherm area Ff,Fs

Motyka 1982 Fluid geochemistry of Makushin Fs,Ff

Motyka 1983 Geochem \& isotope study water \& gas Makushin Fs,Ff

Motyka $1983 \mathrm{High}$ temp hydrothermal resources Aleut arc $R, F G, F f$ 
Motyka \& Moorman 1981 Recon thermal spr Aleutian arc R,Fs,Ff Motyka \& Queen 1984 Makushin fluids samps \& well $10 \mathrm{~g}$ Fs,Ff,Fw,PG Motyka \& others 1981 Assmt thermal spring Aleutian arc R,FG,Ff,Gr Motyka \& others 1982 Fluid geochemistry Makushin area Fs, Ff Motyka \& others 1983 Fluid investigations Makushin area Fs, Ff Mótyka \& others 1983 Geothermal resources of Alaska R, Fs,Ff, Fw Motyka \& others 1986 Makushin well chem equilib *,Fw,Fs,Ff,HA, RM Nichols \& Reeder 1983 Ak geothermal \& hydrotherm development $R, D P$ Nye \& Swanson 1986 Chem strat magma plumb Makushin [abs] V,Gs,PG Nye \& Swanson 1987 Makushin magma chamber Nye others 1984 Geol map Makushin geothermal area Nye \& others 1986 Petro geochem Quat volc Makushin *,V,Gs, PG PG, GE, V Parmentier \& others. 1983 Geol \& hydrotherm alter Makushin Gs,HA Queen 1984 Lith log \& hydrotherm alt of core from Makushin HA Queen 1987 Alt, H2O-rock equil, Makushin (thesis) HA, Fw, Gs, Gc, HS Queen \& Motyka 1984 Changes in Makushin geoth system [abs.] HA Reeder $1981 \mathrm{~V}-\mathrm{D}$ hydrotherm maifest Unalaska [abs.] Gs,Ff Reeder 1982 Hydrotherm potential Aleut arc - Makushin [abs] DP Reeder 1982 Hydrothermal resources Makushin region Reeder 1982 Hydrothermal resources N Unalaska Is Fs, Ff Reeder 1984 Fault \& dike orientation Makushin [abs.] Gr Reeder others $1980 \mathrm{Ak}$. geothermal program

Reeder \& others 1982 Econ \& eng geoth develop Makushin EF,Eg,DP Reeder others 1985 Geol geotherm resource Makushin R, Gs Republ1c 1983 Unalaska Gtrml Proj 1B Er,HS,Fs,Ff,Gs, Ps,DP, RM, HA Republ1c 1984 Unalaska Gtrml Prof II Er,HS,Fs,Fw,Gs, Ps,DP,RM, HA Republic 1985 Unalaska Gtrml Proj III *,Er,HS,Fw,Gs, Ps, DP, RM, HA Shore 1985 Resist survey \& interp Snyder \& Fraser 1963 P1llowed lavas Unalaska Ps, RM Spencer \& others 1982 Anal geothrm res devel Unalaska EF,DP Swanson 1983 Min \& fract Makushin volc [abs.] Swanson \& others 1983 Petro Makushin volc [abs.] Turner \& others 1980 Geothermal resources Alaska

Berry \& others 1980 Thermal spring 11st U.S. Bliss 1983 Ak basic data thermal springs \&ells R,Fs,Fw Brew \& others 1984 Geologic map Peterbrg, Sumdum, P. Alex Gr Brook \& others 1979 Hydrothermal systems $<90$ deg Buddington \& Chapin 1929 Geol \& mineral deposits SE Ak Economides Arce 1983 Geothermal in Ak - eng \& geol anal Economides others 1982 Eng, geol anal geothermal sites Jackson 1880 Alaska 1 ts missions knopf 1912 sitka mining district Ioney others 1964 Recon geol map Baranof \&ruzof Is Ioney others 1967 Radio ages \& fault movements $N$ SE AK R, Fs Gr $\mathrm{EF}, \mathrm{Ex}$ EF, Er H, C $\mathrm{H}, \mathrm{Gr}$ Gr Ioney others 1975 Recon geol Chlchagof, Baranof \& Kruzof Is Gr Markle 1979 Geotherm Ak site data base \& devel status $R, F s, G r, C$ Miller 1973 Distribution d, chem analysis thermal springs Ak R, Fs Motyka \& Moorman 1987 Geotherm resourcers SE Ak R,Fs, FW Motyka \& others 1983 Geothermal resources of Alaska R,Fs,Ff,Fw Muffler 1979 Assmt geothermal resources U. S. Nava 1975 Note on hot springs SE AK $R, F s$, HS R, FE 
Peale 1886 Mineral springs of US H, R

Reeder \& others 1980 Ak. geothermal program DP

Reifenstuhl 1984 Crawfish Inlet Pluton Baranof Is [abs.] Gs,PG Reifenstuhl 1984 Geol geophys Goddard HS (thesis) Gs,Ps,Fs Reifenstuhl 1986 Geol Goddard Hot Springs Rosenthal 1908 Hot springs of southeast Alaska Turner \& others 1980 Geothermal resources Alaska Gs, Ps, Fs Twenhofel \& Sainsbury 1958 Fault patterns SE Ak

* Waring 1917 Mineral springs Ak

Waring 1965 Thermal springs US \& world - a summary White \& Williams 1975 Assmt geothermal resources US Wright 1906 Nonmetallic deposits SE Ak.

Granite Mt. NC-8

Berry \& others 1980 Thermal spring list U.S.

Bliss $1983 \mathrm{Ak}$ basic data thermal springs \& wells $\mathrm{R}, \mathrm{Fs}, \mathrm{Fw}$ Gassaway \& Abramson 1977 Map \& table thermal springs cntr Ak R, Fs Hudson 1977 Geol map Seward Penin Gr Markle 1979 Geotherm Ak site data base devel status R,Fs,Gr,C Miller 1970 Petro plutonic rocks $W$ central Ak PG Miller 1971 petro plutonic rocks $W$ cent Ak (thesis) PG Miller $1972 \mathrm{~K}$ rich intrusive rocks $\mathrm{W}$ Ak PG Miller 1973 Distribution chem analysis thermal springs AK R,Fs Miller \& others 1972 Prelim geol map Solomon \& SE Bendeleben $Q$ Gr Miller \& others 1975 Geol \& chem hot springs $W$ cent Ak Motyka \& others 1983 Geothermal resources of Alaska Reed \& others 1983 Data low temp geothermal systems US HS,R,Fs Robinson \& Stevens 1983 Geol map Seward Penin Robinson \& Stevens 1984 Geol map Seward Penin Turner \& Swanson 1981 Continent rifting new model seward Pen Turner \& others 1980 Geothermal resources Alaska Turner \& others 1981 continent rifting new model seward Pen Waring 1917 Mineral springs Ak Waring 1965 Thermal springs US \& world - a summary White \& Willams 1975 Assmt geothermal resources US

* Berry \& others 1980 Thermal spring list U.S.

Bliss 1983 Ak basic data thermal springs \& wells

Brook \& others 1979 Hydrothermal systems <90 deg

- Byers \& Brannock 1949 Volc activity Umnak \& Great sitkin Is Coats 1956 Recon geol $\mathrm{W}$ Aleutian Islands Markle 1979 Geotherm Ak site data base \& devel status R,Fs,Gr,C Miller 1973 Distribution \& chem analysis thermal springs Ak R, Fs Miller \& Barnes 1974 Geotherm devel Ak [abs.] Miller \& Barnes 1976 Geotherm develop Ak summary DP, Gr,V Motyka $1983 \mathrm{High}$ temp hydrothermal resources Aleut arc $R, F s, F f$ Motyka \& others 1983 Geothermal resources of Alaska R,Fs,Ff,Fw Muffler 1979 Assmt geothermal resources $U$. $S$. Poreda \& others $1981 \mathrm{He}$ isot vars Ak-Aleut arc [abs.] Shelikhov 1790 Voyage to America 1783-1786 R, Fs, HS simons \& Mathewson 1955 Geol Great Sitkin Is R, Fs, Ff $\mathrm{H}, \mathrm{C}$ Gr 
Smith \& Shaw 1979. Igneous related geothermal systems Turner \& others 1980 Geothermal resources Alaska Waring 1965 Thermal springs Us \& world - a summary White \& WIIlams 1975 Assmt geothermal resources US

$$
\begin{array}{r}
R, H S \\
R, F s \\
F s \\
R, F s, H S
\end{array}
$$

Hague $\quad A A-30$

Kennedy \& Waldron 1955 Geol Pavlof volcano Motyka \& others 1983 Geothermal resources of Alaska Turner \& others 1980 Geothermal resources Alaska

Hawk NC-9

Berry \& others 1980 Thermal spring list U.S. Bl1ss 1983 Ak basic data thermal springs \& wells R, Fs, Fw Gassaway Abramson 1977 Map \& table thermal springs cntr Ak R, Fs Markle 1979 Geotherm Ak site data base \& devel status R,Fs,Gr,C Miller 1970 Petro plutonic rocks $W$ central Ak Miller 1971 Petro plutonic rocks $W$ cent Ak (thesis) PG Miller $1972 \mathrm{~K}$ rich intrusive rocks W Ak Milier 1973 Distribution chem analysis thermal springs Ak R,Fs Miller \& others 1975 Geol \& chem hot springs $W$ cent Ak R,Fs Motyka \& others 1983 Geothermal resources of Alaska R,Fs,Ff, Fw Patton \& others 1968 Reg geol map Shungnak Ambler River $Q$ Gr Reed \& others 1983 Data low temp geothermal systems US HS,R,Fs Rosenbruch \& Bottge 1975 Econ potent 3 sites Ak Turner others 1980 Geothermal resources Alaska EF

Hornor NC-16

Berry \& others 1980 Thermal spring list U.S. $\mathbf{R}$ Bliss 1983 Ak basic data thermal springs \& wells $R, F s, F w$ Gassaway A Abramson 1977 Map \& table thermal springs cntr Ak R,Fs Markle 1979 Geotherm Ak site data base devel status R,Fs,Gr,C Miller 1973 Distribution \& chem analysis thermal springs Ak R,Fs Miller \& others 1975 Geol chem hot springs $W$ cent Ak $R, F s$ Motyka \& others 1983 Geothermal resources of Alaska R,Fs,Ff,Fw Nava Morrison 1974 Note on hot springs interior Ak R,Fs Patton \& Hoare 1968 Kaltag Fault W-C Ak Reed \& others 1983 Data low temp geothermal systems US HS,R,Fs Reeder \& others 1980 Ak. geothermal program silberman \& others 1978 Age of rocks Ruby, Medfra adj $Q$ Turner \& others 1980 Geothermal resources Alaska Waring 1917 Mineral springs Ak Waring 1965 Thermal springs US world - a summary Whymper 1868 Journey Norton Sound to Fort Yukon

Hot springs BaY AA-22

Baker \& others 1977 Geotherm springs-salmon hatchery site $R, D P, F s$ Berry \& others 1980 Thermal spring 11st U.S. Bliss 1983 Ak basic data thermal springs wells Byers \& Barth 1948 Geol Akutan Island Byers \& Barth 1953 Volc activity Akun \& Akutan Islands $R, F s, F W$ Gr 
Coats 1956 Recon geol Aleutian Islands Gr Markle 1979 Geotherm Ak site data base \& devel status R,Fs,Gr,C Miller 1973 Distribution \& chem analysis thermal springs Ak R, Fs Motyka 1982 Fluid geochem Makushin \& Akutan geotherm area Ff,Fs Motyka $1983 \mathrm{HIgh}$ temp hydrothermal resources Aleut arc $R, F s, F f$ Motyka $1983 \mathrm{High}$ temp hydrothermal resources Aleut arc R,Fs,Ff Motyka \& Moorman 1981 Recon thermal spr Aleutian arc R,Fs,Ff Motyka o others 1981 Assmt thermal spring Aleutian arc R,Fs,Ff, Gr Hotyka \& others 1982 Fluid geochem Hot springs Akutan Fs, Ff Motyka \&, others 1983 Geothermal resources of Alaska R, Fs, Ff, Fw Motyka \& others 1985 Geol geoc geophys Akutan *,Gs,Fs, Ps,RM,Ff,DP Peale 1886 Mineral springs of US

Romick 1982 Ig petro \& geochem N. Akutan Is (thesis) $\mathrm{H}, \mathrm{R}$

Romick 1983 Ig petro geochem N. Akutan Is [abs.] PG

Romick 1986 Ig pet and geochem N. Akutan

Romick \& Swanson 1983 Petro \& fract lava Akutan Is [abs.] Turner o others 1980 Geothermal resources Alaska Waring 1965 Thermal springs US \& world - a summary Wescott others 1982 Geophys survey Hot Springs Akutan Is White W1Iliams 1975 Assmt geothermal resources US R,Fs, HS

Hot springs Cove AA-14

Berry \& others 1980 Thermal spring list U.S. Black 1974 Geol \& ancient Aleuts

Black 1974 Late Quat sea level changes Umnak Is

Black 1975 Late Quat geomorph Umnak Is

Black 1976 Geol Umnak related to Aleuts

Bliss 1983 Ak basic data thermal springs \& wells

Brook \& others 1979 Hydrothermal systems <90 deg

Byers 1959 Geol Umnak \& Bogoslof Islands

1961 Petro 3 volc suites Umnak \& Bogoslof Islands Forbes \& others 1975 Utilization geothermal rural Ak

Markle 1979 Geotherm Ak site data base devel status R,FG,Gr,C Miller 1973 Distribution \& chem analysis thermal springs Ak R, Fs Motyka $1983 \mathrm{High}$ temp hydrothermal resources Aleut arc R,Fs, Ff Motyka Moorman 1981 Recon thermal spr Aleutian arc R,Fs,Ff Motyka \& others 1981 Assmt thermal spring Aleutian arc R,Fs,Ff, Gr Motyka \& others 1983 Geothermal resources of Alaska . R,Fs,Ff,Fw Muffler 1979 Assmt geothermal resources U. S. Ogle 1976 Ak. hot spring site for small binary plant R, Fs, HS Reeder \& others 1980 Ak. geothermal program Turner \& others 1980 Geothermal resources Alaska Waring 1965 Thermal springs US \& world - a summary White \& Williams 1975 Assmt geothermal resources US R, DP, Fs DP R. IS Fs R, Fs, HS

Hutlinana NC-29

Berry \& others 1980 Thermal spring list U.S. Bliss 1983 Ak basic data thermal springs \& wells Foster \& others 1970 Geol Yukon-Tanana upland [abs.] Foster \& others 1973 Geology Yukon-Tanana upland Gr Gassaway \& Abramson 1977 Map \& table thermal springs cntr Ak R,Fs 
Markle 1979 Geotherm Ak site data base devel status R,Fs,Gr,C Mertie 1932 Yukon Tanane region Gr Mertie 1934 Mineral deposits Rampart \& Hot Springs district Gr Miller 1973 Distribution \& chem analysis thermal springs Ak R, Fs Miller \& others 1975 Geol \& chem hot springs W cent AK R,Fs Motyka \& others 1983 Geothermal resources of Alaska R,Fs,Ff, Fw Nava \& Morrison 1974 Note on hot springs interior Ak Reed \& others 1983 Data low temp geothermal systems US Turner \& others 1980 Geothermal resources Alaska Waring 1917 Mineral springs Ak Waring 1965 Thermal springs US \& world - a summary $R, F s$ $H S, R, F s$ R, Fs Fs, R Fs

Iliamna SC-12

Capps 1935 Southern Alaska Range Detterman \& Hartsock 1966 Geol Inlskin-Tuxedni region Detterman \& others $1976 \mathrm{Geol}$ map by faults in Kenal \& Tyonek $Q$ Gr Estes 1978 Seismotectonic studies lower cook Inlet (thesis) Pr Johnson 1979 Volc gas studies Ak volcanoes R, Ff Juhle 1955 Illamna Volcano Kienle \& Swanson 2983 Volc E Aleut arc I Quat \& Holo cntrs V,PG Kienle \& Swanson 1983 Volc E Aleut arc Quat \& Holo centers V,PG Martin \& Katz $1910 \mathrm{Geol}$ \& min resources Illamna \& Lake Clark $\mathrm{H}, \mathrm{Gr}$ Martin \& Katz 1912 Geol recon Iliamna Region $\mathrm{H}, \mathrm{Gr}$ Motyka others 1983 Geothermal resources of Alaska R, Fs, Ff, Fw Page \& others 1982 Selsm Spurr, Redoubt, \& Illamna [abs.] V Poreda others 1981 He lsot vars Ak-Aleut arc [abs.] R,Fs,Ff Prosser 1912 volcanic road-building

Riehle 1985 Recon Holo tephra deposits upper Cook Inlet White \& Williams 1975 Assmt geothermal resources us White williams 1975 Assmt geothermal resources Us W1] son Rienle 1976 Infrasontc signals Augustine volo [abs],

Inmachuk NC-37

Herre1d 1966 Geol \& geochem Inmachuk RIver Gr

Hopkins 1963 Imuruk Lake Seward Penin $\quad$ Gr

Hudson 1977 Geol map Seward Penin $\quad$ Gr

Lockhart 1981 Gravity survey central seward Penin. $\quad$ Pr

Miller $1972 \mathrm{~K} \cdot \mathrm{rlch}$ intrusive rocks $\mathrm{W}$ Ak PG

Moffit 1905 Falrhaven gold placers Seward Penin H,Gr

Robinson \& Stevens 1983 Geol map Seward Penin Gr

Robinson \& Stevens 1984 Geol map seward Penin Gr

Turner \& others 1980 Geothermal resources Alaska R, Fs

Waring 1917 Mineral springs Ak $\quad$ Fs, R

Waring 1965 Thermal springs US world - a summary 4 Fs

Ishtalitna NC-22

Chapman others 1975 Prelim geol map Tanana \& NE Kantishan Q Gr Chapman others 1982 Recon geol map Tanana $Q \quad$ Gr Dover \&ayaoka 1985 Rocks Ray Mts, Tanana \& Bettles $Q$ Gr Markle 1979 Geotherm Ak site data base devel status R,Fs,Gr,C Motyka \& others 1983 Geothermal resources of Alaska R,Fs,Ff,FW 
Patton \& Miller 1970 Prelim geol invest Kanuti Silberman \& others 1978 Age of rocks Ruby, Medfra \& adj $Q$ Turner \& others 1980 Geothermal resources Alaska

Kagami1 AA-11

Berry \& others 1980 Thermal spring list U.S. Markle 1979 Geotherm Ak site data base devel status R,Fs,Gr,C Miller 1973 Distribution \& chem analysis thermal springs Ak R, Fs Motyka \& others 1981 Assmt thermal spring Aleutian arc R,Fs,Ff,Gr Motyka o others 1983 Geothermal resources of Alaska R,FG,FE,FW Turner \& others 1980 Geothermal resources Alaska Waring 1965 Thermal springs US \& world - a summary White \& Williams 1975 Assmt geothermal resources US R,Fs

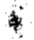

Kaguyak SC-2I

Allen \& Zles 1923 Chem study fumaroles Ratmal region Ff Berg \& Keinle 1966 Gravity meas Katmal volc area Bordet \& others 1963 Katmal Decker 1964 Geophys investigations Ratmal [abs.] Johnson 1980 Volc contr Cl to stratosphere Keller \& Reiser 1959 Geol Katmal Kienle 1968 Gravity Survey Katmal (thesis) Rienle 1969 Gravity traverse VTTS, Ratmal [abs.] Kienle \& Swanson 1983 volc E Aleut arc I Quat \& Holo cntrs Kienle \& Swanson 1983 Volc $E$ Aleut arc Quat \& Holo centers Kienle others 1981 volcanic centers Katmal [abs.]

Kosco 1981 Andesitic volcanism at Katmal

Kosco 1981 Edgecumbe volc \& Katmai (thesis)

Kubota \& Berg 1967 Magma in Katmal range

Matumoto lig7l Selsm body waves Kattmat \& molten Matumoto \& Ward 1967 Microquake study Katmal

- Morris 1985 Katmal Park draft management plan Shipley 1919 VTTS Smith 1925 Cold Bay Katmal dist Smlth \& Baker 1924 Cold Bay-Chignik dist Smith \& Shaw 1979 Igneous related geothermal systems Swanson \& Kienle 1982 Volc centers Ratmai Swanson \& others 1981 Geol \& petro Kaguyak Crater [abs.] White \& Williams 1975 Assmt geothermal resources Us

Kañaga AA-3

Berry \& others 1980 Thermal spring list U.S.

Coats 1947 Geol N Kanaga Is.

Coats 1952 Magmatic different Adak \& Kanaga Islands

Coats 1956 Geol N Kanaga Island

Coats 1956 Recon geol $\mathrm{W}$ Aleutian Islands

Fraser \& Barnett 1959 Geol Delarof Andreanof Islands

Markle 1979 Geotherm Ak site data base \& devel status Motyka \& others 1983 Geothermal resources of Alaska Peale 1886 Mineral springs of us Shellkhov 1790 Voyage to America $1783-1786$ 
Smith \& Shaw 1979 Igneous related geothermal systems Turner \& others 1980 Geothermal resources Alaska Waring 1965 Thermal springs US \& world - a summary White \& Williams 1975 Assmt geothermal resources Us Wilcox 1959 Volcanic ash falls Alaska

Kanuti NC-25

Berry \& others 1980 Thermal spring 11st U.S. Bliss 1983 Ak basic data thermal springs \& wells Brook \& others 1979 Hydrothermal systems $<90$ deg Dover \& Mayaoka 1985 Rocks Ray Mts, Tanana \& Bettles $Q$ $R, F s, F w$ Gassaway a Abramson 1977 Kap tobie thermal Bpring Markle 1979 Geotherm Ak site data base devel status $\mathrm{Fs}$ Gr Hiller 1973 Distribution chem analysis thermal springs Ak R, Fs Miller \& others 1975 Geol chem hot springs W cent Ak Motyka \& others 1983 Geothermal resources of Alaska Muffler 1979 Assmt geothermal resources U. $S$. Patton Miller 1970 Prelim geol invest Kanuti Turner others 1980 Geothermal resources Alaska White W1IILams 1975 Assmt geothermal resources Us

Ratmai sC-6

Allen \& zies 1923 Chem study fumaroles Katmal region

Anma 1971 Aeromag survey VTTS (thesis)

Berg \& Keinle 1966 Gravity meas Katmal volc area

Berg \& others 1967 Crustal structure - Katmal

Berry others 1980 Thermal spring list U.S.

Bordet \& Tazieff 1963 Erupt of Katmal \& ignimbrites

Bordet \& others 1963 Ratmai

Chalgneau Bordet 1963 Gas in glass in VTS (Fr)

Clark 1912 Katmal eruption

Curt 1s 1955 Importance of Novarupta [abs.]

Curt1s 1968 stratigraphy of ejecta 1912 eruption Katmal

Daily 2912 Eruption of Katmal

Decker 1964 Geophys investigations Katma1 [abs.]

Eickelberger H1Idreth 1986 Drilling In Katmal [abs.]

Escher 1922 Lahar VTTS

Federman \& Scheidegger 1984 Distal tephra 1912 Novarupta

Fenner 1920 Geol Katmal 1912 eruption [abs.]

Fenner 1920 Katmal great eruption of 1912

Fenner 1923 Tuff deposit VTTS

Fenner 1923 Tuff deposit VTTS

Fenner 1926 Ratmal magmatic province

Fenner 1930 Mt Katmal \& Magelk

Fenner 1937 Tuffs of Ratmal \& Yellowstone

$R, F G, F E, F W$

R, Fs

$R, F G, H S$

Gr

$R, F s$

$R, F E$, HS

Fenner 1950 Chemical kinetics Katmai eruption

Fierstein \& Hildreth 1984 Pyroclastic deposits Novarupta [abs.] V

Forbes \& Blggar 1973 Ak geothermal resource potentlal

Forbes \& Kienle 1971 Petro pre 1912 pyroclast VTTS [abs]

Fry 1912 Mineral content volcanic ashes

Gedney \& others 1970 Selsmic refraction - Katmai

Griggs 1917 VTTS 


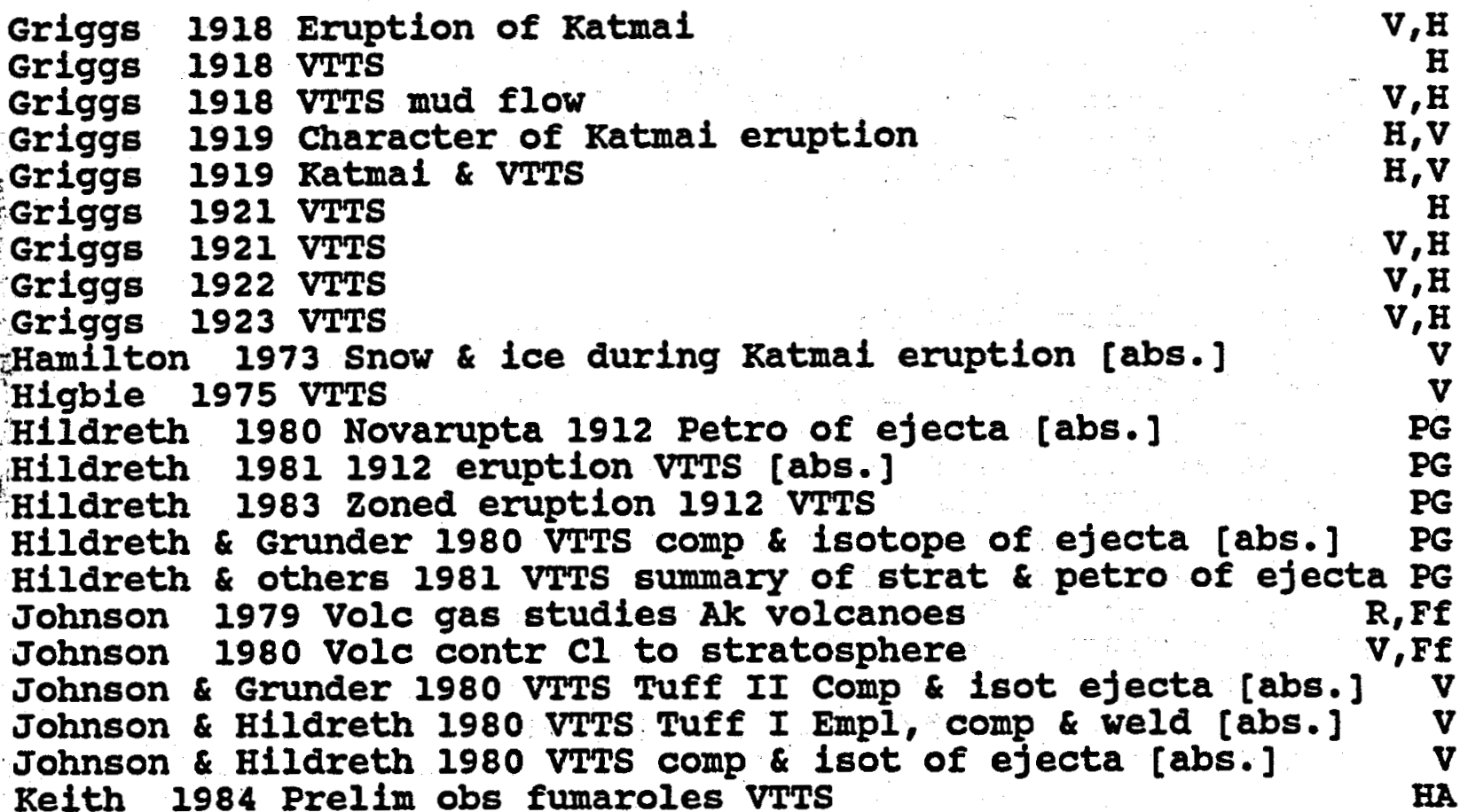
Keith 1985 Hydrotherm alt Novarupta dome VTTS [abs.] HA

Keller 1955 Geol Katmai [abs.]

Keller \& Reiser 1959 Geol Katmal

Kienle 1968 Gravity Survey Ratmal (thesis)

Rienle 1969 Gravity traverse VTTS, Katmal [abs.]

Kienle 1970 Gravity traverse VTTS

Kienle \& Swanson 1983 Volc E Aleut arc I Quat \& Holo cntrs V,PG

Kienle swanson 1983 Volc E Aleut arc Quat \&olo centers V,PG

Kienle \& others 1970 seism evidence pre 1912 tuff VTTS [abs.] Gr

Kienle others 1981 Volcanic centers Katmal [abs.] $V, R$

Kosco 1981 Andesitic volcanism at Katmal

Kosco 1981 Edgecumbe volc \& Katmal (thesis)

PG

Kubota Berg 1967 Magma in Katmal range V,Pr

Lovering 1955 Alteration near halogen-sulfur fumarole [abs.] $\mathrm{HA}$

Lovering 1957 Halogen-acid alteration VTTS HA, Ff

MacGregor 1952 Eruptive mechanisms VTTS

Markle 1979 Geotherm Ak site data base \& devel status R,Fs,Gr,C

Martin 1913 Eruption Katmai $\quad V, H$

Matumoto 1971 Seism body waves Katmal \& molten chmbr [abs.] Pr,V

Matumoto \&oInar 1967 shadow effect $S$ waves Katmal [abs.] Pr,V

Matumoto \& Ward 1967 Microquake study Katmal $\mathbf{P r}, \mathrm{V}$

Menyaylov 1969 Comparison Bezymyany Katmal (Rus) V,Ff

Milier 1973 Distribution \& chem analysis thermal springs Ak R,Fs

Miller \& Barnes 1974 Geotherm devel Ak [abs.]

Miller \& Barnes 1976 Geotherm develop Ak summary

Morris 1985 Katmai Park draft management plan

Motyka 1977 Katmal caldera geothermal activity

Motyka 1978 Surveillance Ratmal caldera \& crater lake

Motyka others 1977 Glac-volc Investigations Katmai [abs.] $v$

Motyka \& others 1983 Geothermal resources of Alaska R,FE,Ff,Fw

Mulier \& others 1954 Volcanic activity Katmal

$D P, G r, V$

Okimura 1930 Eruption Katmai 
Poreda \& others -1981 He lsot vars Ak-Aleut arc [abs.]

Ramdohr 1962 Magnetite from fumaroles VTTS (Ger)

$R, F G, F f$

Reck 1930 Review VTTS (Ger)

Roehn 1941 pumice deposits Ratmal k:

Rubenstone \& others 1985 Isot \& trace elem Katmal [abs.]

Sayre \& Hagelbarger 1918 Temps in VTTS

Sbar \& Matumoto 1972 Refraction VTTS

Shlpley 1919 VTTS

Shipley 1920 Chem obs VTTS

Shlpley 1920 Katmal gas \& encrustations

Smith 1925 Cold Bay Ratmai dist

Smith \& Baker 1924 Cold Bay-Chignik dist

Smith \& Shaw 1979 Igneous related geothermal systems

Sosman 1919 Temp in fumaroles VTTS

Stone \& Packer 1972 Paleomag VTSS [abs.]

Stone \& others 1971 Magnetic anomalies VTrs [abs.]

Swanson \& Klenle 1982 Volc centers Katmai

Tams 1924 Katmal (Ger)

Thompson \& Kelth $1984 \mathrm{Cl}$ \& $\mathrm{F}$ in waters VTTS [abs.]

Turner others 1980 Geothermal resources Alaska

Ward \& Matumoto 1967 Sum volc seismic activity Katmal

Ward \& Ward 1966 Volc activity in Katmai

Waring 1917 Mineral springs Ak

Waring 1965 Thermal springs US \& world - a summary

Wilcox 1959 Volcanic ash falls Alaska

Williams 1955 Prelim geol Katmal \& VTTS

W1111ams others 1956 Mt Katmal VTTS new interp 1912 eruptn V

zies 1921 Hot springs in VTTS

Zies 1924 Fumarolic Incrustations Ratmal [abs.]

Fs

zies 1924 Fumarolic incrustations VTTS

Zles 1929 VTTS I-fumarolic Incrustations, II-acid gases

HA

HA

FE,

Kennore AA-26

Bl1ss 1983 Ak basic data thermal springs \& wells

Motyka \& Moorman 1981 Recon thermal spr Aleutian arc

$R, F s, F w$

Motyka \& others 1981 Assmt thermal spring Aleutian arc

$R, F s, F f$

Motyka \& others 1983 Geothermal resources of Alaska

Turner \& others 1980 Geothermal resources Alaska

$R, F s, F f, G r$

$R, F s, F f, F w$

R, Fs

KiIo NC-23

Bliss 1983 Ak basic data thermal springs \& wells R,Fs,Fw Chapman \& others 1975 Prelim geol map Tanana \& NE Kantishan $Q$ Gr Chapman \& others 1982 Recon geol map Tanana $Q \quad$ Gr Dover \& Mayaoka 1985 Rocks Ray Mts, Tanana \& Bettles Q Gr Gassaway \& Abramson 1977 Map \& table thermal springs cntr Ak R,Fs Markle 1979 Geotherm Ak site data base \& devel status R,Fs,Gr,C Miller 1973 Distribution chem analysis thermal springs AK R, Fs Miller \& others 1975 Geol chem hot springs w cent Ak R,Fs Motyka \& others 1983 Geothermal resources of Alaska R,Fs,Ff,Fw Nava Morrison 1974 Note on hot springs interior Ak $R$, Fs Patton \& Miller 1970 Prelim geol Invest Kanut1 Reed others 1983 Data low temp geothermal systems Us HS, R, Fs 
Silberman \& others 1978 Age of rocks Ruby, Medfra \& adj Q Turner \& others 1980 Geothermal resources Alaska

Kliuchef AA-7

Berry \& others 1980 Thermal spring list U.S.

$\mathbf{R}$

Coats 1956 Recon geol W Aleutian Islands

Gr Markle 1979 Geotherm Ak site data base \& devel status R,Fs,Gr,C Marsh 1980 Geol \& petrol N Atka Is [abs.] Gr Miller 1973 Distribution \& chem analysis thermal springs Ak R, Fs Miller \& Barnes 1974 Geotherm devel Ak [abs.]

Miller \& Barnes 1976 Geotherm develop AK summary Motyka $1983 \mathrm{HIgh}$ temp hydrothermal resources Aleut arc

Motyka \& Moorman 1981 Recon thermal spr Aleutian arc

Motyka \& others 1981 Assmt thermal spring Aleutian arc

Motyka o others 1983 Geothermal resources of Alaska

Myers \& others 1986 Isot var Adak \& Atka volc plumb

Peale 1886 Mineral springs of US

Reeder \& others 1980 Ak. geothermal program

Turner \& others 1980 Geothermal resources Alaska

Waring 1965 Thermal springs US \& world - a summary

White \&illiams 1975 Assmt geothermal resources US

$D P, G r, V$

$D P, G r, V$

$R, F s, F f$

R, Fs, Ff

$R, F s, F f, G r$

$R, F s, F f, F w$

$V, P G, G r$

$\mathrm{H}, \mathrm{R}$

DP

R, Fs

FE

Korovin $\quad A A-6$

Baker Eggler 1983 Atka high alumina basalt

PG

Berry others 1980 Thermal spring list U.S.

Coats 1956 Recon geol W Aleutian Islands

Gr

Markle 1979 Geotherm Ak site data base \& devel status R,Fs,Gr,C Marsh 1980 Geol \& petrol N Atka Is [abs.] Gr Milier 1973 Distribution \& chem analysis thermal springs Ak R,Fs Motyka $1983 \mathrm{High}$ temp hyarothermal resources Aleut arc $R, F s, F f$ Motyka \& Moorman 1981 Recon thermal spr Aleutian arc R,Fs,Ff Motyka \& others 1981 Assmt thermal spring Aleutian arc R,Fs,Ff, Gr Motyka \& others 1983 Geothermal resources of Alaska Myers \& others 1986 Isot var Adak \& Atka volc plumb Peale 1886 Mineral springs of US

Reeder \& others 1980 Ak. geothermal program Turner \& others 1980 Geothermal resources Alaska Waring 1965 Thermal springs US \& world - a summary White \& Williams 1975 Assmt geothermal resources US

$R, F s, F f, F w$ V, PG, Gr $\mathbf{H}, \mathbf{R}$ DP R, Fs Fs $\mathrm{R}, \mathrm{Fs}, \mathrm{HS}$

Kukak . SC-9

7

*llen \& Zies 1923 Chem study fumaroles Katmal region Griggs 1919 Katmal \& VTTS

Kienle \& Swanson 1983 Volc E Aleut arc L Quat \& Holo cntrs

Kienle \& Swanson 1983 Volc E Aleut arc Quat \& Holo centers

Kosco 1981 Andesitic volcanism at Katmal

Kosco 1981 Edgecumbe volc \& Katmai (thesis)

MacGregor 1952 Eruptive mechanisms VTTS

Morris 1985 Katmal Park draft management plan

Motyka \& others 1983 Geothermal resources of Alaska

Muller others 1954 Volcanic activity Katmai

Ff

$\mathrm{H}, \mathrm{V}$

$\nabla$, PG

$V, P G$

PG

PG

$C, D P$

$R, F s, F f, F w$

V 
Reck 1930 Revlew VTTS (Ger)

Smith 1925 Cold Bay Katmal dist

White W11liams 1975 Assmt geothermal rêsources Us

$\mathrm{Gr}, \mathrm{H}$

AA-33

Detterman \& others 1979 Geol map Chignik \& Sutwik Is $Q$

Gr

Detterman \& others 1981 Geol map Chignik \& Sutwik Is $Q$

Gr

Detterman \& others 1981 Quat geol map Chignik \& Sutwik Is $Q$ Gr

Eakins 1969 Sulfur deposit stepovak Bay [abs.]

Hubbard 1931 Geol Anlakchak \&eniaminof [abs.]

Hubbard 1931 World Inside a mountain

Knappen 1933 Anlakchak \&eniaminof volcanoes [abs.]

Lecompte \& Steele 1981 Map Iandsat Chignik \& Sutwik Is Q

Gr

Maddren 1919 Sulfur on Unalaska \& Akun Is \& Stepovak Bay

Motyka \& others 1983 Geothermal resources of Alaska

Palache 1904 Geol Chlchagof Cove, stepovak Bay

Prosser 1912 Volcanic road-bullding

Yount others 1985 Eruption Mt Veniaminof

Yount \& others 1985 New Holo vent Port Moller \& stepovak Bay Q

Kwinluk NC-6

BIIss 1983 Ak basic data thermal springs \& wells

Forbes \& others 1975 Utilization geothermal rural Ak

Hudson 1977 Geol map Seward Penin

Markle 1979 Geotherm Ak site data base devel status R,Fs,Gr,C

Miller $1972 \mathrm{~K}$ rich intrusive rocks $\mathrm{W}$ Ak

R,FE, Fw

Miller 1973 Distribution \& chem analysis thermal springs Ak R,Fs Miller \& others 1972 Prellm geol map Solomon \& SE Bendeleben Q Gr Miller \& others 1975 Geol c chem hot springs $W$ cent Ak R,Fs Motyka \& others 1983 Geothermal resources of Alaska Reed \& others 1983 Data low temp geothermal systems US

Robinson \& Stevens 1983 Geol map Seward Penin

Robinson stevens 1984 Geol map seward Penin

Turner \& others 1980 Geothermal resources Alaska

Waring 1917 Mineral springs Ak

Waring 1965 Thermal springs US \& world - a summary $R, F s, F f, F w$ $H S, R, F G$

Gr

Gr

R,Fs

Fs, R FE

Lava Creek NC-4

Berry \& others 1980 Thermal spring list U.S.

Bliss 1983 Ak basic data thermal springs \& wells

Brook \& others 1979 Hydrothermal systems $<90$ deg

Hudson 1977 Geol map Seward Penin

Hudson \& Plafker 1978 Kigluaik * Bendeleben faults

Markle 1979 Geotherm Ak site data base \& devel status R,Fs,Gr,C Miller $1972 \mathrm{~K}$ rich intrusive rocks $\mathrm{W}$ Ak

Milier 1973 Distribution \& chem analysis thermal springs Ak R, Fs Miller \& others 1972 Prelim geol map Solomon \& SE Bendeleben $Q$ Gr Miller \& others 1975 Geol \& chem hot springs W cent AK Motyka \& others 1983 Geothermal resources of Alaska Muffler 1979 Assmt geothermal resources $U$. $S$. R,Fs $R, F s, F f, F w$ $\mathrm{R}, \mathrm{Fs}$, HS 
Reed \& others 1983 Data low temp geothermal systems US HS,R,Fs Robinson \& Stevens 1983 Geol map Seward Penin Gr Robinson \& Stevens 1984 Geol map Seward Penin Gr Turner \& Swanson 1981 Continent rifting new model seward Pen Gr Turner \& others 1980 Geothermal resources Alaska Turner \& others 1981 Continent rifting new model seward Pen Gr Turner \& others 1981 Continent rifting new model seward Pen Gr White \& Williams 1975 Assmt geothermal resources US R,Fs, HS

\section{Little Melozitna, NC-20}

Berry \& others 1980 Thermal spring list U.S.

Bliss 1983 Ak basic data thermal springs \& wells R, Fs, FW

Brook \& others 1979 Hydrothermal systems $<90$ deg

R, Fs

Cass 1959 Recon geol map Melozitna Q Ak.

Gr

Forbes \& others 1975 Utilization geothermal rural Ak Fs,DP,Ef Gassaway \& Abramson 1977 Map \& table thermal springs cntr Ak R,Fs Markle 1979 Geotherm Ak site data base \& devel status R,Fs,Gr,C Miller 1973 Distribution \& chem analysis thermal springs Ak R, Fs Miller \& others 1975 Geol \& chem hot springs $w$ cent Ak Motyka \& others 1983 Geothermal resources of Alaska Muffler 1979 Assmt geothermal resources U. S. R, Fs Patton \& others 1978 Geol map Melozitna Q Silberman \& others 1978 Age of rocks Ruby, Medfra \& adj $Q$ $R, F s, F f, F w$ Turner \& others 1980 Geothermal resources Alaska

$R, F s$, HS

Ach \& Delong 1980 Magma evo L. Sitkin \& Semisopochnoi [abs.] PG Berry \& others 1980 Thermal spring list U.S. Coats 1956 Recon geol $\mathrm{W}$ Aleutian Islands Iewis \& others 1960 Geol Rat Islands, Aleutians

1979 Geotherm Ak site data base \& devel status R,Fs,Gr,C Miller 1973 Distribution chem analysis thermal springs Ak R, Fs Miller \& Barnes 1974 Geotherm devel Ak [abs.] Miller \& Barnes 1976 Geotherm develop Ak summary Motyka \& others 1983 Geothermal resources of Alaska Smith \& Shaw 1979 Igneous related geothermal systems snyder 1959 Geol Iittle sitkin Is Turner \& others 1980 Geothermal resources Alaska Waring 1965 Thermal springs US \& world - a summary White \& Willams 1975 Assmt geothermal resources US $\mathrm{DP}, \mathrm{Gr}, \mathrm{V}$ $D P, G r, V$ $R, F s, F f, F w$ $R$, HS

Lower Division NC-II

Berry others 1980 Thermal spring list U.S.

Bliss 1983 Ak basic data thermal springs \& wells R,Fs,Fw Gassaway \& Abramson 1977 Map \& table thermal springs cntr AK R, Fs Markle 1979 Geotherm Ak site data base devel status R,Fs,Gr,C Miller 1970 Petro plutonic rocks $w$ central Ak Miller 1971 Petro plutonic rocks $W$ cent Ak (thesis) PG PG 
Miller 1972 arich intrusive rocks $\mathrm{W} \mathrm{Ak}$ PG Miller 1973 Distribution chem analysis thermal springs Ak R,Fs Miller others 1966 Prelim plutonic belt $W$ cent Ak Gr Miller others 1975 ,Geol chem hot springs $W$ cent Ak R,Fs Motyka o others 1983 Geothermal resources of Alaska R,Fs,Ff, Fw Nava Morrison 1974 Note on hot springs interior Ak R, Fs Patton \& others 1968 Reg geol map shungnak \& Ambler River $Q$ Gr Reed others 1983 Data low temp geothermal systems US HS, R, Fs Rosenbruch \& Bottge 1975 Econ potent 3 sites Ak Turner \& others 1980 Geothermal resources Alaska R, Fs

Lower Klawasi SC-16

AGS 1975 Drum thermal springs area $\quad$ DP Andreasen \& others 1958 Aeromag Copper River basin $\quad$ Pr Andreasen \& others 1964 Geol inter mag \& grav Copper Rvr basn Pr Berry \& others 1980 Thermal spring list U.S.

Bliss 1983 Ak basic data thermal springs wells R,Fs,Fw

Church \& others 1970 Copper River basin strat correl section Gs

Economides Arce 1983 Geothermal in AK - eng \& geol anal EF,Er Economides \& others 1982 Eng,geol anal geothermal sites EF,Er Emery \& Jones 1984 Hydrologic atlas Copper RIver basin Gs Emmel \& Coonrod 1982 Geol Literature Copper River basin Gr Ferrians \& Nichols 1965 Copper River basin Gr Ferrians \& Schmoll 1957 WIsc progalcial lake copper River bsn Gr Ferrians o others 1958 Pleist volc muaflow Copper River basin $V$ Ferrians \& others 1983 Copper River basin Gr Foresman 1968 Photogeol \& geomorph Copper River basin Gs Foresman 1970 Mud volcanoes Copper RIver basin (thesis) Gs Grantz \& others 1962 Saline springs Copper River basin Fs Hawkins \& Motyka 1985 stat \& chem anal H2O Copper River bsn Fs, Fw Henning others 1981 Wrangell-St Ellas Wilderness Markle 1979 Geotherm Ak site data base devel status R,FG,Gr,C Mendenhall 1903 Mineral resources Mt Wrangell district $H, G r$ Mendenha11, 1905 Geology central Copper River region H,Gr Motyka others 1983 Geothermal resources of Alaska R,Fs,Ff,Fw Motyka \& others 1986 Geochem lsot org mud volc Copper R Fs, Ff, Fw Nichols \& Yehle 1961 Anal gas \& water Copper River basin Fs Nichols \& Yehle 1961 Mud volc Copper River basin Fs Nichols Yehle 1969 Eng geol map SE Copper River basin Gs Reed \& others 1983 Data low temp geothermal systems US HS,R,Fs Reeder others 1980 Ak. geothermal program

Reitsema 1979 Gases of mud volc Copper River basin stoltzfus 1982 Copper River basin planning study Turner \& others 1980 Geothermal resources Alaska Turner others 1983 Sum, eval gthrm exp Copper R bsn Gs,Ps,Fs, RM Wescott \& Turner 1983 Geotherm expl E copper $R$ basin Ps,Gc,Fs, Fw Wescott \& Turner 1983 Geotherm potent Copper $R$ basin Gs,Ps,Gc,DP Wescott \& Turner 1985 Geotherm Invest Copper *,Gs, Ps, Gc, DP, Fs, Fw Williams 1985 Eng geol map Copper River basin

Yehle \& others 1985 Geol frm arilling in Copper R. basin Eg Gr 
Lower RaY NC-26

Berry \& others 1980 Thermal spring list U.S.

Bliss 1983 Ak basic data thermal springs wells R,Fs,Fw Chapman \& others 1975 Prelim geol map Tanana \& NE Kantishan Q Gr Chapman \& others 1982 Recon geol map Tanana $Q$ Gr Gassaway \& Abramson 1977 Map \& table thermal springs cntr Ak R, Fs Markle 1979 Geotherm Ak site data base \& devel status R,Fs,Gr,C Miller 1973 Distribution chem analysis thermal springs Ak R, Fs Miller \& others 1975 Geol chem hot springs $W$ cent AK R, Fs Motyka \& others 1983 Geothermal resources of Alaska R,Fs,Ff, Fw Patton \& Miller 1970 Prelim geol invest Kanuti Reed \& others 1983 Data low temp geothermal systems US FS, R, Fs Silberman \& others 1978 Age of rocks Ruby, Medfra \& adj $Q$ Gr Turner \& others 1980 Geothermal resources Alaska

Waring 1917 Mineral springs Ak

Waring 1965 Thermal springs US \& world - a summary

R,Fs Fs, R Fs

Makushin Valley . AA-18

Allely 1986 selsmic refraction Makushin

Arce 1983 Volcanic hazards Makushin Volcano (thesis)

Arce Economides 1982 Volcanic hazards Makushin Volcano

Beebee \& Kirkwood 1979 Unalaska-geothermal prospects

Berry \& others 1980 Thermal spring list U.S.

Boyd \& Jacob 1984 Selsmicity of Unalaska

Campbell Economides 1984 Summary Well no. 1 Makushin volc

regs, \& environ

Carrick \& Maurer 1986 Hydrology - Makushin

Coats 1956 Recon geol $\mathbf{W}$ Aleutian Islands

Combellick 1986 Eng geol power plant site Makushin

Corwin \& Fitterman 1983 Self potential Makushin geotherm area Ps Davies 1986 Selsmic hazards - Makushin

Denig-Chakroff 1985 Unalaska recon study

Eg, Ps

Drewes \& others 1961 Geol Unalaska \& adjacent shelf

Economides \& Arce 1983 Geothermal in Ak - eng \& geol anal

Economides \& others 1981 Unalaska geothermal development

Economides \& others 1982 Eng,geol anal geothermal sites

EI, DP

Economides \& others 1985 Eval Makushin geothermal reservoir

Holmes 1986 Archaelogical evaluation Makushin

Isselhardt \& others 1983 Geotherm resource model Makushin RM, HS

Isselhardt \& others 1983 Temp grads Makushin geothermal area HS

Jacob \& Boyd 1985 Seismic network on Unalaska

Jones 1986 Coastal engineering - Makushin

Krause 1986 Power \& road corridor study Makushin

Iong 1986 Glacial hazard Makushin

Pr

Eg

$E g, P s, D P$

March 1986 Avalanche hazards- Makushin

Martin 1917 Mineral resources of Ak.

Matlick \& Parmentier $1983 \mathrm{Hg}$ soll survey Makushin Gc,
Morrison-Knudson Co. 1981 Geotherm potential Aleut Unalaska

$\mathrm{H}, \mathrm{Gr}$ Motyka 1982 Fluid geochem Makushin \& Akutan geotherm area Ff,Fs Motyka 1982 Fluid geochemistry of Makushin Motyka 1983 Geochem \& isotope study water \& gas Makushin

Fs, Ff

Fs, Ff 
Motyka $1983 \mathrm{High}$ temp hydrothermal resources Aleut arc $R, F s, F f$ Motyka \& Moorman 1981 Recon thermal spr Aleutian arc R,Fs,Ff Motyka \& Queen 1984 Makushin fluids samps \& well 109 Fs,Ff,Fw,PG Motyka \& others 1981 Assitt thermal spring Aleutian arc R,Fs,Ff, Gr Motyka \& others 1982 Fluid geochemistry Makushin area Fs,Ff Motyka \& others 1983 Fluid investigations Makushin area Fs,Ff Motyka \& others 1983 Geothermal resources of Alaska R,Fs,Ff,Fw Motyka \& others 1986 Makushin well chem equilib *,Fw,Fs, Ff, HA, RM Nichols \& Reeder 1983 Ak geothermal \& hyrotherm development $R, D P$ Nye 1986 Volcanic hazards, Makushin V,Eg Nye \& Swanson 1986 Chem strat magma plumb Makushin [abs] V,Gs, PG Nye \& Swanson 1987 Makushin magma chamber Nye \& others 1984 Geol map Makushin geothermal area Nye \& others 1986 Petro geochem Quat volc Makush in $P G, G s, V$ Parmentier \& others 1983 Geol \& hydrotherm alter Makushin Gs,HA Peale 1886 Mineral springs of US $\quad H, R$ Queen 1984 Ith $10 \mathrm{~g}$ \& hydrotherm alt of core from Makushin HA Queen 1987 Alt, H2O-rock equil, Makushin (thesis) HA, FW, Gs, GC,HS Queen \& Motyka 1984 Changes in Makushin geoth system [abs.] HA Reeder $1981 \mathrm{~V}-\mathrm{D}$ hydrotherm maifest Unalaska [abs.] Gs, Ff Reeder 1982 Hydrotherm potential Aleut arc - Makushin [abs] DP

- Reeder 1982 Hydrothermal resources Makushin region DP

*... Reeder 1982 Hydrothermal resources N Unalaska Is

Reeder 1984 Fault \& dike orientation Makushin [abs.]

Reeder 1986 Ground stability, spring water Broad Bay

Reeder \& others 1980 Ak. geothermal program

Fs, Ff Gr

Reeder \& others 1982 Econ \& eng geoth develop Makushin EF,Eg,DP Reeder \& others 1985 Geol geotherm resource Makushin $\mathbf{R}, \mathrm{Cs}$ Republic 1983 Unalaska Gtrml Proj 1B Er,HS, Fs, Ff, Gs, Ps, DP, RM, HA Republ1c 1984 Unalaska Gtrml Proj II Er,HS, Fs, Fw, Gs, Ps, DP, RM, HA Republic 1985 Unalaska Gtrml Proj III *,Er,HS, Fw, Gs, Ps, DP, RM, HA Shore 1985 Resist survey \& interp

Snyder Fraser 1963 Pillowed lavas Unalaska

Spencer others 1982 Anal geothrm res devel unalaska

Swanson $1983 \mathrm{MIn}$ \& fract Makushin volc [abs.]

Swanson others 1983 Petro Makushin volc [abs.]

Ps, RM

Gr

Tumer \& others 1980 Geothermal resources Alaska

Updike 1986 Construction materials Makushin

Updike 1986 Eng geol, feasibil study Makushin *,Eg,Gs, Ps,Fs,DP

Makushin Volcano AA-16

Arce 1983 Volcanic hazards Makushin Volcano (thesis) Eg

Arce Economides 1982 Volcanlc hazards Makushin Volcano ... Eg

Berry \& others 1980 Thermal spring list U.S.

Boyd \& Jacob 1984 Selsmicity of Unalaska

Brown 1899 Shlshaldin

Campbe11 Economides 1984 Summary Well no. 1 Makushin volc Er

Carey others 1983 unalaska geotherm land, regs, \& environ DP

Corwin \& Fitterman 1983 Self potential Makushin geotherm area $\mathrm{Ps}$

Davidson 1884 First ascent Makushin

Davidson 1884 New volcano in Alaska

Davidson 1893 Eruption of Ventaminof

$\mathbf{H}, \mathbf{V}$

Denig-Chakroff 1985 Unalaska recon study

$\mathrm{H}, \mathrm{V}$

EF 
Diller 1884 Volcanic sand Unalaska

Drewes \& others 1961 Geol Unalaska \& adjacent shelf

Economides \& Arce 1983 Geothermal in Ak - eng \& geol anal EF,Er

Economides \& others 1981 Unalaska geothermal development DP

Economides \& others 1982 Eng, geol anal geothermal sites EF,Er

Economides \& others 1985 Eval Makushin geothermal reservoir Er

House others 1981 Selsmic gap near Unalaska

Isselhardt \& others 1983 Geotherm resource model Makushin RM,HS

Isselhardt \& others 1983 Temp grads Makushin geothermal area HS

Jacob \& Boyd 1985 Selsmic network on Unalaska

Lawton 1909 Makushin sulfur deposits

$\operatorname{Pr}$

Maddren 1919 Sulfur on Unalaska Akun Is \& Stepovak Bay

Markle 1979 Geotherm Ak site data base \& devel status R,Fs,Gr,C Martin 1917 Mineral resources of Ak.

Matlick \& Parmentier $1983 \mathrm{Hg}$ soil survey Makushin

Miller 1973 Distribution \& chem analysis thermal

Miller \& Barnes 1974 Geotherm devel Ak [abs.]

M1ller \& Barnes 1976 Geotherm develop Ak summary

Morrison-Knudson Co. 1981 Geotherm potential Aleut Unalaska

Motyka 1982 Fluid geochem Makushin \& Akutan geotherm area Ff,Fs

Motyka 1982 Fluid geochemistry of Makushin

Motyka 1983 Geochem \& isotope study water \&

Motyka others 1982 Fluid geochemistry Makushin area

Motyka \& others 1983 Fluid Investigations Makushin area Fs, Ff

Motyka \& others 1983 Geothermal resources of Alaska R, Fs, Ff, Fw Motyka \& others 1986 Makushin well chem equilib *, FW, Fs, Ff, HA, RM Nichols \& Reeder 1983 Ak geothermal \& hydrotherm development R,DP Nye 1986 Volcanic hazards, Makushin

$\mathbf{V}, \mathbf{E g}$

Nye \& Swanson 1986 Chem strat magma plumb Makushin [abs] V,Gs,PG

Nye \& Swanson 1987 Makushin magma chamber

Nye \& others 1984 Geol map Makushin geothermal area

Nye \& others 1986 Petro geochem Quat volc Makushin

$P G, G S, V$

$*, V, G s, P G$

Parmentier \& others 1983 Geol \& hydrotherm alter Makushin Gs, HA

Perfit \& others 1980 Model for fract in Aleut calc-alk suite PG

Queen 1984 Lith $\log$ \& hydrotherm alt of core from Makushin HA

Queen 1987 Alt, H2O-rock equil, Makushin (thesis) HA, Fw, Gs, Gc, HS

Queen \& Motyka 1984 Changes in Makushin geoth system [abs.] HA

Reeder 1981 V-D hydrotherm malfest Unalaska [abs.] Gs,Ff

Reeder 1982 Hydrotherm potential Aleut arc - Makushin [abs] DP

Reeder 1982 Hydrothermal resources Makushin region

Reeder 1982 Hydrothermal resources $\mathbb{N}$ Unalaska Is Fs, Ff

Reeder 1983 Prelim dating Holo volcanic E Aleut Is [abs.] V,Gr

Reeder 1984 Fault \& dike orientation Makushin [abs.] Gr

Reeder others 1980 Ak. geothermal program DP

Reeder \& others 1982 Econ \& eng geoth develop Makushin EF,Eg,DP

Reeder \& others 1985 Geol geotherm resource Makushin R, Gs

Republic 2983 Unalaska Gtrml Proj 1B Er,HS,Fs,Ff,Gs,Ps,DP,RM, HA

Republic 1984 Unalaska Gtrml Proj II Er,HS,Fs,Fw,Gs,Ps,DP, RM, HA

Republic 1985 Unalaska Gtrml Proj III *,Er,HS, Fw, Gs, Ps, DP, RM, HA

Shore 1985 Resist survey \& interp

Smith \& Shaw 1979 Igneous related geothermal systems

Ps, RM

Snyder \& Fraser 1963 Pillowed lavas Unalaska

Spencer others 1982 Anal geothrm res devel

Swanson 1983 Min \& fract Makushin volc [abs.]

$R$, HS

Gr

$E F, D P$

PG 
Swanson \& Blum 1984 Evol of volc centers Aleutian arc [abs] $\nabla, G r$ Swanson others 1983 Petro Makushin volc [abs.] PG Updike 1986 Eng geol, feśstbil study Makushin
Veniaminov 284, Gs, Ps, Fs, DP Waring 1965 Thermal springs Us \& world - a summary White \& WIIlams 1975 Assmt geothermal resources US wilcox 1959 Volcantc ash fails Alaska

Manley NC-27, NC-28

Bl1ss 1983 Ak baslc data thermal springs \& wells

Brook \& others 1979 Hydrothermal systems <90 deg R,FE, FW R,FS Chapman \& others 198 . East 1982 Recon geol map Tanana $Q$ East 1982 Geotherm investigation Manley HS (thesis) East 1982 Prelim geothermal Investigation Manley HS Forbes o others 1975 Utilization geothermal rural Ak Gs, Fs, Fs
Forbes \& others 1975 Utilization of Alaska thermal springs DP, Ef
Foster DP Foster others 1070 Geol Yukon-Tanana upland [abs.] Foster \& others 1973 Geology Yukon-Tanana upland Gr

Gassaway \& Abramson 1977 Map \& table thermal springs cntr Ak R,Fs Hopkins \& Taber 1962 stratigraphy Manley HS

* King 1909 Tanana Valley

Leonard 1975 Geothermal energy

Markle 1979 Geotherm Ak site data base devel status $R, F s, G r, C$
Meaker 1908 Tanana Valley

* Mertie 1932 Yukon Tanana region

- Mertie

1934 Mineral deposits Rampart \& Hot springs alstrict Gr Milier 1973 Distribution \& Chem analysis thermal springs Ak R,Fs Motyka \& others 1975 Geol \& chem hot springs $W$ cent Ak Muffler 1979 Assmt geothermal resources $U$. $S$. Ogle $1976 \mathrm{Ak}$. hot spring site for small binary plant Reed others 1983 Data Iow temp geothermal systems Us Reeder \& others 1980 Ak. geothermal program Silberman \& others 1978 Age of rocks Ruby, Medfra \& adj 0 Turner \& others 1980 Geothermal resources Alaska Waring 1917 Mineral springs $\mathrm{AK}$ Waring 2965 Thermal springs US \& world - a summary White \& WIIlams 1975 Assmt geothermal resources US

\section{Questen NC-2I}

Chapman others 1975 Prelim geol map Tanana \& NE Kantishan $Q$ Gr Chapman others 1982 Recon geol map Tanana $Q$ Dover \& Mayaoka 1985 Rocks Ray Mts, Tanana \& Bettles Q Motyka \& others 1983 Geothermal resources of Alaska Motyka \& others 1983 Geothermal resources of Alaska Patton \&11ler 1970 Prelim geol invest Kanuti S1lberman others 1978 Age of rocks Ruby, Medfra \& adj \& $R, F S, F f, F w$ $R, F s, H S$ $R, D P, F S$ HS , R, Fs DP
$\mathbf{G r}$
$\mathrm{R}, \mathbf{F s}$
$\mathrm{Fs}, \mathbf{R}$
$\mathrm{Fs}$ Turner \& others 1980 Geothermal resources Alaska 
Melozi NC-17

Berry \& others 1980 Thermal spring 1ist U.S.

Bliss 1983 Ak basic data thermal springs \& wells

Brook \& others 1979 Hydrothermal systems <90 deg

$R, F s, F w$

$R, F s$

Cass 1959 Recon geol map Melozitna $Q$ Ak.

Gr

Dillon \& others 1983 Geol map Melozitna A-4 Quad

Gr

Gassaway \& Abramson 1977 Map \& table thermal springs cntr Ak R,Fs

Markle 1979 Geotherm Ak site data base \& devel status R,Fs,Gr,C Miller 1973 Distribution \& chem analysis thermal springs Ak R, Fs Miller \& others 1975 Geol \& chem hot springs $w$ cent Ak Motyka \& others 1983 Geothermal resources of Alaska R,Fs,Ff, Fw Muffler 1979 Assmt geothermal resources U. S.

Nava \& Morrison 1974 Note on hot springs interior Ak

Ogle $1976 \mathrm{Ak}$. hot spring site for small binary plant

Patton \& others 1978 Geol map Melozitna $Q$

Silberman \& others 1978 Age of rocks Ruby, Medfra \& adj $Q$

$R, F \boldsymbol{B}, \mathrm{HS}$

R, Fs

Turner \& others 1980 Geothermal resources Alaska

Waring 1917 Mineral springs Ak

Waring 1965 Thermal springs Us \& world - summary

White \& Williams 1975 Assmt geothermal resources US

$R, D P, F S$

Gr

Gr

R,Fs

Fs, R

Fs

R,FE,HS

MilkY River AA-18

Baker \& Eggler 1983 Atka high alumina basalt

PG

Marsh 1980 Geol \& petrol N Atka Is [abs.]

Motyka $1983 \mathrm{High}$ temp hydrothermal resources Aleut arc R,Fs,Ff

Motyka \& others 1983 Geothermal resources of Alaska R,Fs,Ff, Fw

Reeder \& others 1980 Ak. geothermal program

Turner \& others 1980 Geothermal resources Alaska

DP

R, Fs

Minook NC-41

Berry \& others 1980 Thermal spring list U.S.

Chapman \& others 1975 Prelim geol map Tanana \& NE Kantishan Q Gr

Chapman \& others 1982 Recon geol map Tanana $Q$

Foster \& others 1970 Geol Yukon-Tanana upland [abs.]

Gr

Foster \& others 1973 Geology Yukon-Tanana upland

Markle 1979 Geotherm Ak site data base \& devel status R,Fs,Gr,C

Mertie 1932 Yukon Tanana region

Gr

Mertie 1934 Mineral deposits Rampart \& Hot springs district Gr

Miller 1973 Distribution \& chem analysis thermal springs Ak R,Fs

Miller \& others 1975 Geol \& chem hot springs $W$ cent Ak R, Fs

Turner \& others 1980 Geothermal resources Alaska

Waring 1917 Mineral springs Ak

Waring 1965 Thermal springs US \& world - a summary

R, Fs

Fs, R

Fs

Mother Goose AA-35

Baker \& others 1977 Geotherm springs-salmon hatchery site R,DP,Fs

Berry \& others 1980 Thermal spring list U.S.

Detterman \& others 1983 Geol map Ugashik-Bristol Bay-Karluk Q Gr

Detterman \& Others 1985 Geol map Ugashik \& W Karluk Q

Gr

Detterman \& others 1986 Quat map Ugashik-Bristol Bay-Karluk Q Gr 
Lecompte 1981 Prelim map Landsat Ugashik \& Karluk $Q$ Gr Markle 1979 Geotherm Ak site data base \& devel status R,Fs,Gr,C Miller 1973 Distribution chem analys'is thermal springs Ak R,Fs Motyka 1983 High temp hydrothermal resources Aleut arc $R, F s, F f$ Motyka \& Moorman 1981 Recon thermal spr Aleutian arc R,Fs,Ff Motyka \& others 1981 Assmt thermal spring Aleutian arc R,Fs,Ff,Gr Motyka \& others 1983 Geothermal resources of Alaska R,Fs,Ff,Fw Nehring \& others 1979 Sulfate geotherm western U. S. R, Fs Smith \& Baker 1924 Cold Bay-Chignik dist Turner \& others 1980 Geothermal resources Alaska

Gr, H

R, Fs

Mt. Douglas $\quad s C-10$

Berry \& others 1980 Thermal spring list U.S. R Estes 1978 Selsmotectonic studies lower Cook Inlet (thesis) Pr Kienle \& Swanson 1983 Volc E Aleut arc $I$ Quat \& Holo cntrs V,PG Klenle \& Swanson 1983 Volc E Aleut arc Quat \& Holo centers V,PG Kosco 1981 Andesitic volcanism at Ratmal Kosco 1981 Edgecumbe volc \& Katmai (thesis) PG Miller 1973 Distribution \& chem analysis thermal springs Ak R,Fs Morris 1985 Katmal park draft management plan C,DP Motyka \& others 1983 Geothermal resources of Alaska R,Fs,Ff,Fw Mulier o others 1954 Volcanic activity Ratmai Swanson \& Rienle 1982 Volc centers Katmal Turner \& others 1980 Geothermal resources Alaska Waring 1965 Thermal springs US \& World - a summary White \& W11Lams 1975 Assmt geothermal resources US $\mathrm{V}, \mathrm{Gr}$ R,Fs Fs R, Fs, HS

Mt. Griggs . SC-5

Allen \& zies 1923 Chem study fumaroles Katmal region Berg \& Keinle 1966 Gravity meas Katmal volc area Berg \& others 1967 Crustal structure - Katmal Bordet \& others 1963 Ratmal

Decker 1964 Geophys Investigations Ratma1 [abs.] Griggs 1919 Katmai \& VTrs Johnson 1979 Volc gas studies Ak volcanoes Johnson 1980 Volc contr Cl to stratosphere Keller 1955 Geol Katmal [abs.]

Keller Reiser 1959 Geol Katmal

Kienle 1968 Gravity Survey Katmal (thesis) Kienle 1969 Gravity traverse VTTS, Katmal [abs.] Kienle \& Swanson 1983 Volc E Aleut arc I Quat \& Holo cntrs Kienle \& Swanson 1983 Volc E Aleut arc Quat \& Holo centers Kienle others 1981 volcanic centers Katmal [abs.] Kosco 1981 Edgecumbe volc \& Katmal (thes1s) Kubota \& Berg 1967 Magma in Katmal range MacGregor 1952 Eruptive mechanisms VTTS

Matumoto 1971 selsm body waves Katmal \& molten chmbr [abs.] $P r, V$ Matumoto \& Ward 1967 Microquake study Katmal

Miller \& Barnes 1974 Geotherm devel Ak [abs.] Miller \& Barnes 1976 Geotherm develop Ak summary Morris 1985 Katmal Park draft management plan $\mathrm{DP}, \mathrm{Gr}, \mathrm{V}$ Motyka \& others 1977 Glac-volc investigations Katmal [abs.] C, DP 
Motyka \& others 1983 Geothermal resources of Alaska

Mulier \& others 1954 Volcanic activity Katmal

Poreda \& others 1981 He isot vars Ak-Aleut arc [abs.]

Reck 1930 Review VTSS (Ger)

Rubenstone \& others 1985 Isot \& trace elem Katmal [abs.]

R, Fs, Ff, Fw

Shipley 1919 VTTS

Smith 1925 Cold Bay Katmai dist

Smith \& Baker 1924 Cold Bay-Chignik dist

Spurr 1900 Recon in SW AK 1898

Swanson \& Kienle 1982 Volc centers Katmal

White W1Iliams 1975 Assmt geothermal resources US
$R, F s, F f$
$\mathrm{H}, \mathrm{V}$
PG
Gr, H
$\mathbf{G r}, \mathbf{H}$
$\mathbf{H}, \mathbf{G r}$
$\mathrm{V}, \mathrm{Gr}$

$R, F s$, HS

Mt. Mageik SC-4

Allen \& zies 1923 Chem study fumaroles Katmai region

Berg \& Keinle 1966 Gravity meas Katmai volc area

Berg \& others 1967 Crustal structure - Ratmal

Bordet \& others 1963 Ratmal

Decker 1964 Geophys investigations Ratmai [abs.]

Fenner 1930 Mt Katmai \& Magelk

Griggs 1919 Ratmal \& VTTS

Jaggar 1927 Eruption of Mageik

Johnson 1979 Volc gas studies Ak volcanoes

Johnson 1980 Volc contr Cl to stratosphere

Keller 1955 Geol Katmai [abs.]

Keller \& Reiser 1959 Geol Ratmai

Klenle 1968 Gravity Survey Ratmal (thesis)

Kienle 1969 Gravity traverse VTTS, Katmai [abs.]

Rienle \& Swanson 1983 Volc E Aleut arc L Quat \& Holo cntrs

Kienle \& Swanson 1983 Volc $E$ Aleut arc Quat \& Holo centers

Kienle others 1981 volcanic centers Katmal [abs.]

Kosco 1981 Andesitic volcanism at Katmal

Kosco 1981 Edgecumbe volc \& Katmal (thesis)

Kubota \& Berg 1967 Magma in Katmal range

MacGregor 1952 Eruptive mechanisms VTTS

Ff

Pr

Ps

V

Ps

$\mathrm{V}, \mathrm{H}$

$\mathbf{H}, \mathbf{V}$

$\mathbf{V}, \mathbf{H}$

R, Fe

$\mathrm{V}, \mathbf{F f}$

$\mathbf{G r}$

Gr

$V, P s$

$V, P s$

$V, P G$

$V, P G$

$\mathbf{V}, \mathbf{R}$

PG

PG

Matumoto 1971 Seism body waves Katmal \& molten chmbr [abs.] Pr,V

Matumoto \& Ward 1967 Microquake study Katma1

Miller \& Barnes 1974 Geotherm devel Ak [abs.]

Miller \& Barnes 1976 Geotherm develop Ak summary

Morris 1985 Katmal Park draft management plan

Motyka \& others 1983 Geothermal resources of Alaska

Mulier \& others 1954 Volcanic activity Ratmai

Reck 1930 Review VTTS (Ger)

$\mathbf{V}, \mathrm{Pr}$

$\mathrm{V}$

Rubenstone \& others 1985 Isot \& trace elem Katmai [abs.]

$\mathrm{Pr}, \mathrm{V}$

Shipley 1919 VTTS

Smith 1925 Cold Bay Katmal dist

Smith \& Baker 1924 Cold Bay-Chignik dist

Swanson \& Kienle 1982 Volc centers Katmal

White \& Williams 1975 Assmt geothermal resources US

$D P, G r, V$

$\mathrm{DP}, \mathrm{Gr}, \mathrm{V}$

C, DP

$R, F S, F f, F w$

V

$\mathrm{H}, \mathrm{V}$

PG.

Gr, H

$\mathbf{G r}, \mathbf{H}$

$\mathrm{V}, \mathbf{G r}$

$R, F$, HS

Mt. Martin $s c-3$

Allen \& zies 1923 Chem study fumaroles Katmai region

Ff

Berg \& Keinle 1966 Gravity meas Katmal volc area

Pr 
Berg \& others 1967 Crustal structure - Katmai

Bordet \& others 1963 Katmal

Decker 1964 Geophys investigations Katmal [abs.]

Griggs 1919 Katmal \& VTTS

Johnson 1980 Volc contr Cl to stratosphere

Keller 1955 Geol Katmal [abs.]

Keller \& Reiser 1959 Geol Ratmal

Rienle 1968 Gravity Survey Ratmal (thesis)

Kienle 1969 Gravity traverse VTTS, Katmal [abs.]

Rienle \& Swanson 1983 Volc E Aleut arc L Quat \& Holo cntrs

Kienle \& Swanson 1983 Volc E Aleut arc Quat \& Holo centers

Kienle \& others 1981 Volcanic centers Katmal [abs.]

Kosco 1981 Andesitic volcanism at Katmal

Kosco 1981 Edgecumbe volc Katmal (thesis)

Kubota \& Berg 1967 Magma in Katmai range

MacGregor 1952 Eruptive mechanisms VTTS

Matumoto 1971 Se1sm body waves Katmal molten chmbr [abs.] $\mathrm{Pr}, \mathrm{V}$

Matumoto * Ward 1967 Microquake study Katma1

Miller \& Barnes 1974 Geotherm devel Ak [abs.]

M1ller \& Barnes 1976 Geotherm develop Ak summary

Morris 1985 Ratmai Park draft management plan

Motyka \& others 1983 Geothermal resources of Alaska

Mulier \& others 1954 Volcanic activity Katmai

Reck 1930 Review VTTS (Ger)

Rubenstone \& others 1985 Isot \& trace elem Katmal [abs.]

Shipley 1919 VTTS

Smith 1925 Cold Bay Katmal dist

Smith \& Baker 1924 Cold Bay-Chlgnik dist

Swanson \& Kienle 1982 Volc centers Katmal

White \& Williams 1975 Assmt geothermal resources US

$\mathrm{H}, \mathrm{V}$

$\mathbf{V}, \mathbf{F f}$

Gr

Gr

$\mathrm{V}, \mathrm{Ps}$

$V, P s$

$V, P G$

$V, P G$

$\checkmark, R$

PG

PG

$V, P r$

Mt. Rynda SE-13

Brew \& others 1984 Geologic map Peterbrg, Sumdum, P. Alex Gr Buddington Chapin 1929 Geol \& mineral deposits SE AK Gr Gr Kerr 1948 stikine \& Iskut RIver area BC, Canada Gr Markle 1979 Geotherm Ak site data base \& devel status R,Fs,Gr,C Motyka \& Moorman 1980 Assmt thermal spring S SE Ak [abs.] R,Fs Motyka \& Moorman 1987 Geotherm resourcers SE Ak R, FE, FW Motyka \& others 1980 Assmt therm spr S SE Ak Motyka others 1983 Geothermal resources of Alaska R,Fs,Ff,Fw Turner \& others 1980 Geothermal resources Alaska R,Fs Wright \& Wright 1908 Ketchikan \& Wrangell mining districts Gr, $\mathrm{H}$

Mt. Spurr SC-14

Capps 1935 Southern Alaska Range Gr Detterman others 1976 Geol map by faults in Kenal \& Tyonek $Q$ Gr Emanuel 1984 Hydro \& volc hazards Mt Spurr [abs.] Eg Juhle \& Coulter 1955 Mt. Spurr eruption 1953 Kienle \& Swanson 1983 Volc E Aleut arc I Quat \& Holo cntrs V,PG Kienle \& Swanson 1983 Volc E Aleut arc Quat \& Holo centers V,PG Miller Smith 1976 New volcanoes Aleutian arc $\mathrm{V}$ Motyka \& others 1983 Geothermal resources of Alaska R,Fs,Ff,FW 
Nye \& Turner 1986 Geology \& geochemistry Spurr [abs.] Gs,PG,V Page \& others 1982 Selsm Spurr, Redoubt, \& Illamna [abs.] V

Powers 1953 Activity Aleut volcanoes

Rlehle 1985 Recon Holo tephra deposits upper Cook Inlet

Turner \& Nye 1986 Geochronology Mt. Spurr

Turner \& Wescott 1986 Geotherm invest Mt. Spurr *,R, Ps, GC,V, Gs, RM

turner \& others $1986 \mathrm{Mt}$. Spurr geothermal project R,Gs,V Turner \& others $1986 \mathrm{Hg}$ and He surveys Mt. Spurr Gc,R Wescott \& others 1985 Prelim rept gthrml invest Mt Spurr Gs,Ps,Ge Wescott \& others 1986 Geophysical surveys Mt. Spurr

wescott \& others 1986 Ice thickness Mt. Spurr summit

\#Wite \& Williams 1975 Assmt geothermal resources US

Wilcox 1953 Eruption Mt Spurr

Wilcox 1959 Volcanic ash falls Alaska

Mt. Trident SC-7

Allen \& zies 1923 Chem study fumaroles Katmai region

Anonymous 1953 Activity of Trident

Anonymous 1953 Eruption of Trident

Berg \& Keinle 1966 Gravity meas Katmai volc area

Berg \& others 1967 Crustal structure - Ratmal

Bordet \& others 1963 Katmai

Decker 1964 Geophys investigations Katma1 [abs.]

Decker 1967 Invest at active volcanoes

Griggs 1919 Ratmai \& VTTS

Johnson 1979 Volc gas studies Ak volcanoes

Johnson 1980 Volc contr Cl to stratosphere

Keller 1955 Geol Katmal [abs.]

Keller \& Reiser 1959 Geol Ratmal

Kienle 1968 Gravity Survey Katmal (thesis)

Rienle 1969 Gravity traverse VTTS, Ratmai [abs.]

Kienle \& Swanson 1983 Volc $E$ Aleut arc I Quat \& Holo cntrs

Kienle \& Swanson 1983 Volc $E$ Aleut arc Quat \&olo centers

Kienle others 1981 Volcanic centers Katmal [abs.]

Kosco 1981 Andesitic volcanism at Katmal

Kosco 1981 Edgecumbe volc \& Katmai (thesis)

Kubota \&erg 1967 Magma in Ratmal range

MacGregor 1952 Eruptive mechanisms VTTS

Hatumoto 1971 selsm body waves Katma1 \& molten chmbr [abs.]

Matumoto \& Ward 1967 Microquake study Katmai

Miller \& Barnes 1974 Geotherm devel Ak [abs.]

Miller \&arnes 1976 Geotherm develop Ak summary

Morris 1985 Ratmai Park draft management plan

Motyka \& others 1983 Geothermal resources of Alaska

Mulier \& others 1954 Volcanic activity Katmal

Powers 1953 Activity Aleut volcanoes

Ray 1967 Geochem \& petro Mt Trident andesites (thesis)

Ray 1967 Geochem \& petro Mt Trident andesites (thesis)
Ray \& others 1966 Petro \& geochem Mt Trident andesites [abs.] PG

Reck 1930 Review VTTS (Ger)

Rubenstone \& others 1985 Isot \& trace elem Katmai [abs.]

$D P, G r, V$

$D P, G r, V$

C, DP

R, FE

V,Ff

Gr

Gr

$\mathrm{V}, \mathrm{Ps}$

$V, P s$

$V, P G$

$V, P G$

$\mathrm{V}, \mathrm{R}$

PG

PG

, Pr

$\checkmark$

Shipley 1919 VTTS

Smith 1925 Cold Bay Ratmai dist

Smith \& Baker 1924 Cold Bay-Chignik dist

R,Fs, Ff, FW

$\mathrm{Pr}, \mathrm{V}$

$P r, V$

FW

V

$\mathrm{H}, \mathbf{V}$

PG

II

$\mathbf{G r}, \mathbf{H}$

Gr, H 
Snyder 1954 Eruption Trident Katmal Spurr 1900 Recon In SW AK 1898

Swanson \& Kienle 1982 Volc centers Katmal

White \& Williams 1975 Assmt geothermal resources US

Wilcox 1959 Volcanic ash falls Alaska

Wilson \& Forbes 1969 Infrasonic waves \& volc erupt [abs.]

wilson \& Forbes 1969 Infrasonic waves Ak volc eruptions

Mt. Wrangel1 SC-18

Andreasen \& others 1958 Aeromag Copper River basin Pr

Andreasen \& others 1964 Geol inter mag \& grav Copper Rvr basn Pr

Benson \& Follett 1986 Photogrammetry study Mt. Wrangell

Benson \& Motyka 1978 Glac-volc Interaction Mt. Wrangell

Benson others 1975 Glac \& volc studies Mt. Wrangell

Benson others 1985 Glacio-volcano studies Mt. Wrangell

Bingham 1967 Ice \& heat studies Mt. Wrangell (thesis)

Blngham \& Benson 1967 Mt. Wrangell lce \& heat studies

Bingham \& Benson 1968 Ash temp variations Mt Wrangell

Church \& others 1970 Copper River basin strat correl section

Dunn 1909 Conquering Mt Wrangell

Emmel \& Coonrod 1982 Geol IIterature Copper River basin

Ferrians \& others 1958 Plelst volc mudflow Copper River basin

Ferrians \& others 1983 Copper River basin

Furst 1968 Recon petrol Mt Wrangell caldera (thesis)

Henning \& others 1976 Alaska's volcanoes

Henning o others 1981 Wrangell-st Elias w1lderness

Mackevett 1976 Geol map Mccarthy Q

Mackevett 1978 Geol map McCarthy $Q$

(thesis) PG

Markle 1979 Geotherm Ak site data base \& devel status $R, F s, G r, C$ Mendenhall 1903 Mineral resources Mt Wrangell district $\mathrm{H}, \mathrm{Gr}$ Mendenhall 1905 Geology central Copper River region H, Gr M11ler Barnes 1974 Geotherm devel Ak [abs.]

Miller \& Barnes 1976 Geotherm develop Ak summary

Miller \& Smith 1976 Ash flows Wrangell volcano

Motyka 1983 Thermal activity Mt Wrangell (thesis)

Motyka 1984 Chem of water gas Mt wrangell [abs.]

$\mathrm{DP}, \mathrm{Gr}, \mathrm{V}$

$D P, G r, V$

$\mathrm{V}, \mathrm{HS}, \mathrm{FE}$

Motyka \& Benson 1982 Flucts in heat flow Mt Wrangell [abs.] V,HS

Motyka others 1978 Increased heat Mt Wrange11 [abs.] HS

Motyka \& others 1980 Mt Wrangell glac meas heat flow [abs.] $V$, HS Motyka others 1983 Geothermal resources of Alaska R,Fs,Ff,Fw

Nye 1982 Wrangell volcs \& microplate accretion [abs.]

Nye 1983 Petro geochem okmok \& Wrangell volcs (thesis) PG,V

Richter 1975 Geol map Nabesna $Q$

Richter 1976 Geol map Nabesna $Q$

Rlchter \& others 1984 Shleld volc Wrangell Mts

Smith \& Shaw 1979 Igneous related geothermal systems $\quad$ R, HS

Stoltzfus 1982 Copper River basin planning study

Turner \& others 1980 Geothermal resources Alaska

R, Fs

Turner \& others 1983 Sum, eval gthrm exp Copper R bsn Gs, Ps, Fs, RM Wendler 1967 Heat flow Mt. Wrangell

Wescott \& Turner 1983 Geotherm expl E copper R basin : Ps, Gc, Fs, Fw

Wescott \& Turner 1983 Geotherm potent Copper R basin, Gs,Ps,GC,DP

Wescott \& Turner 1985 Geotherm invest Copper *,Gs, Ps,GC, DP, Fs, FW 
White \& Williams 1975 Assmt geothermal resources US Williams \& Johnson 1980 Map Tert \& Quat deposits Valdez Q Winkler \& others 1981 Follo Valdez $Q$ Workman 1979 signif volc in prehist of subarctic Yehle \& Nichols 1980 Recon map Chetaslina debris flow Copper R V

Neka Bay SE-2

Brew Ford 1985 Geol map Juneau, Taku, Atlin, Skag Quad Buddington \& Chapin 1929 Geol \& mineral deposits SE AK Knopf 1912 sitka mining district Loney \& others 1963 Recon geol map Chichagof \& NW Baranof Is Gr Loney \& others 1967 Radio ages \& fault movements N SE AK Gr Ioney \& others 1975 Recon geol Chlchagof, Baranof \& Kruzof Is Gr Markie 1979 Geotherm Ak site data base \& devel status R,Fs,Gr,C Miller 1973 Distribution \& chem analysis thermal springs Ak R,Fs Motyka \& Moorman 1987 Geotherm resourcers SE Ak Motyka \& others 1983 Geothermal resources of Alaska Nava 1975 Note on hot springs SE Ak Rossman 1959 Geol \& ore dep NW Chichagof Is Turner \& others 1980 Geothermal resources Alaska Twenhofel \& Sainsbury 1958 Fault patterns SE Ak Waring 1965 . Thermal springs US \& world - a summary $R, F G, F W$ R, Fs,Ff, FW R, Fs Gr $R, F s$ Gr Fs

North Peril strait SE-4

Berry \& others 1980 Thermal spring list U.S. Bliss 1983 Ak basic data thermal springs \& wells Buddington \& Chapin 1929 Geol \& mineral deposits SE Ak R, Gr Decker 1980 Geol Cret. subduct complx Chlchagof Is (thesis) Gr Decker 1980 Geol map W ChIchagof Island Knopf 1912 sitka mining district Ioney \& others 1963 Recon geol map Chlchagof \& Baranof Is $H, G$ Ioney \& others 1967 Radio ages \& fault movements N SE AK Is Gr Ioney others 1975 Recon geol Chlchagof, Baranof \& Kruzof Is Gr Markle 1979 Geotherm Ak site data base \& devel status R,Fs,Gr,C Martin 1917 Mineral resources of Ak. H, Gr Miller 1973 Distribution \& chem analysis thermal springs Ak R,Fs Motyka \& Moorman 1987 Geotherm resourcers SE Ak $R, F s, F w$ Motyka \& others 1983 Geothermal resources of Alaska

Nava 1975 Note on hot springs SE AK

Reed \& others 1983 Data low temp geothermal systems US $R, F G, F f, F W$ Rossman 1959 Geol \& ore dep NW Chichagof Is Turner \& others 1980 Geothermal resources Alaska Twenhofel \& Sainsbury 1958 Fault patterns SE AK Waring 1917 Mineral springs Ak

Waring 2965 Thermal springs US \& world - a summary $R, F f, F W$
$R, F s$ HS, $R, F S$ Gr $R, F G$ Gr Fs, R FG

Novarupta $S C-20$

Allen \& Zies 1923 Chem study fumaroles Katmal region Ff Anma 1971 Aeromag survey VTTS (thesis) Berg \& Reinle 1966 Gravity meas Katmai volc area Berg \& others 1967 Crustal structure - Ratmal 
Bordet others 1963 Katmal

Chalgneau \& Bordet 1963 Gas in glass in VTrS

Curtis 1955 Importance of Novarupta [abs.]

Curtis 1968 stratigraphy of ejecta 1912 eruption katma

Dally 1912 Eruption of Katma1

Decker 1964 Geophys Investigations Katmal [abs.]

Elckelberger Hildreth 1986 Drilling in Katmal [abs.]
Escher 1922 Lahar VTTS

Federman \& Scheldegger 1984 Distal tephra 1912 Novarupta

Fenner 1920 Geol Katmal 1912 eruption [abs.]

Fenner 1923 Tuff deposit VTTS

Fierstein \& Hildreth 1984 Pyroclastlc deposits Novarupta

Fierstein \& Hildreth 1986 Novarupta ejecta [abs.]

Forbes Kienle 1971 Petro pre 1912 pyroclast VTTS [abs]

Fry 1912 Mineral content volcanic ashes

Gedney others 1970 Selsmic refraction - Ratmal

Griggs 1918 Eruption of Katmal

Griggs 1918 VTTS mud flow

Griggs 1919 Character of Katmal eruption

- Grlggs 1919 Katmal \& VTTS

Griggs 1921 VTTS

Griggs 1922 VTTS

Griggs 1923 VTTS

Hamilton 1973 snow \& lce during Katmal eruption [abs.]
Higbie 1975 VTrS

H1Idreth \& Flerstein 1986 Novarupta near vent ejecta [abs.]

Johnson 2980 Volc contr Cl to stratosphere

Johnson \& Grunder 1980 VTTS Tuff II Comp \& 1sot ejecta [abs.

Johnson \& Hildreth 1980 VTTS Tuff I Empl, comp \& weld [abs.]
Keith 1984 prelim obs fumaroles VTTS

Kelth 1985 Hydrotherm alt Novarupta dome VTrs [abs.]

Keith 1986 Hydrothermal alteration Novarupta [abs.]

Keller 1955 Geol Katmai [abs.]

Keller \& Relser 1959 Geol Ratmal

Klenle 1968 Gravity Survey Katmal (thesis)

Rienle 1969 Gravity traverse VTTS, Katmal [abs.]

Kienle 1970 Gravity traverse VTTS

Kienle \& others 1981 Volcanlc centers Katmal [abs.]

Kosco 1981 Andesitic volcanism at Katmal

Kosco 1981 Edgecumbe volc \& Katmal (thesis)

Rubota \& Berg 1967 Magma in Katmal range

MacGregor 1952 Eruptive mechanisms VTTS

Matumoto 1971 Seism body waves Katmai molten chmb

Matumoto \&ard 1967 Microquake study Katmal

MiIler \& Barnes 1974 Geotherm devel Ak [abs.]

Miller Barnes 1976 Geotherm develop Ak summary

Morris 1985 Katmal Park draft management plan

Ramdohr 1962 Magnetite from fumaroles VTrs (Ger)

Reck 1930 Review VITS (Ger)

Rubenstone \& others 1985 Isot \& trace elem Katmal [abs.]

Sbar \& Matumoto 1972 Refraction VTTS

Shipley 1919 VTTS

Shlpley 1920 Katmal gas \& encrustations 
Smith 1925 Cold Bay Ratmal dist

Smith \& Baker 1924 Cold Bay-Chignik dist

Smith \& Shaw 1979 Igneous related geothermal systems

Stone others 1971 Magnetic anomalies VTTS [abs.]

Swanson \&ienle 1982 Volc centers Katmal

White \& Williams 1975 Assmt geothermal resources US

$$
\begin{array}{r}
\text { Gr,H } \\
\text { Gr,H } \\
R, H S \\
\text { Pr } \\
V, G r \\
R, F s, H S
\end{array}
$$

Nylen SE-7

Berry \& others 1980 Thermal spring list U.S.

Bliss $1983 \mathrm{Ak}$ basic data thermal springs \& wells

Buddington \& Chapin 1929 Geol \& mineral deposits SE Ak

Knopf 1912 sitka mining district

Loney \& others 1963 Recon geol map Chlchagof \& NW Baranof Is Gr

Ioney \& others 1967 Radio ages \& fault movements N SE Ak

Ioney \& others 1975 Recon geol Chichagof, Baranof \& Ruzof Is Gr Markle 1979 Geotherm Ak site data base \& devel status R,Fs, Gr,C Motyka \& Moorman 1987 Geotherm resourcers SE Ak Motyka \& others 1983 Geothermal resources of Alaska R,Fs,Ff, Fw Reed \& others 1983 Data low temp geothermal systems US HS, R, Fs Rossman 1959 Geol \& ore dep NW Chlchagof Is Turner \& others 1980 Geothermal resources Alaska Twenhofel \& Sainsbury 1958 Fault patterns SE AK Gr R,Fs Gr

Okmok AA-15

Berry \& others 1980 Thermal spring list U.S.

Black 1974 Geol \& ancient Aleuts

Black 1974 Late Quat sea level changes Umnak Is

Black 1975 Late Quat geomorph Umnak Is

Black 1976 Geol Umnak related to Aleuts

Bliss 1983 Ak basic data thermal springs \& wells

Byers 1959 Geol Umnak \& Bogoslof Islands

Byers 1961 Petro 3 volc suites Umnak \& Bogoslof Islands

Byers \& Brannock 1949 .Volc activity Umnak \& Great sitkin Is

Davidson 1884 New volcano in Alaska

Forbes \& Biggar 1973 Ak geothermal resource potential

Katsul 1984 Okmok

Markle 1979 Geotherm Ak site data base \& devel status

Miller \& Barnes 1974 Geotherm devel Ak [abs.]

Miller \& Barnes 1976 Geotherm develop Ak summary

Miller \& Smith 19762 caldera forming eruptions Umak

Hotyka \& others 1981 Assmt thermal spring Aleutian arc

Motyka \& others 1983 Geothermal resources of Alaska

Nye 1983 Petro \& geochem Okmok \& Wrangell volcs (thesis)

Nye \& Reid 1986 Geochem pri lava Okmok Volc: arc magmagene

Nye \& others 1983 Parental magmas Okmok: arc magmagen [abs.] PG

Petrov 1884 Alaska population \& resources

Poreda \& others 1981 He isot vars Ak-Aleut arc [abs.] R,Fs,Ff

Reeder 1983 Prelim dating Holo volcanic $E$ Aleut Is [abs.] V,Gr

Reeder 1984 Okmok

Reeder \& others 1980 Ak. geothermal program

Robinson 1948 Exploring Aleutian volc

Smith \& Shaw 1979 Igneous related geothermal systems

$\mathrm{V}, \mathrm{H}$

$\mathrm{R}, \mathrm{HS}$ 
Turner \& others 1980 Geothermal resources Alaska

VonLangsdorff 1814 Voyages \& travels 1803-1807

$R, F S$, HS

White \& Willams 1975 Assmt geothermal resources US

R,Fs, HS

wilcox 1959 Volcanic ash falls Alaska

Okpilak NC-35

Bader 1984 Geol map eastern N. slope Ak. $\quad$ Gr

Bader \& Bird 1986 Geol map NE Alaska

Berry others 1980 Thermal spring list U.S.

Bliss 1983 Ak basic data thermal springs \& wel1s

Brook \& others 1979 Hydrothermal systems $<90$ deg

R, Fs, FW

Markle 1979 Geotherm Ak site data base devel status

Motyka \& others 1983 Geothermal resources of Alaska

Muffler 1979 Assmt geothermal resources U. $S$.

$R, F E, G r, C$

Pavia 1986 structure \& strat okpllak batholith area

Reed \& others 1983 Data low temp geothermal systems us

Robinson \& others 1986 Geol map Mt. Michelson C-4 Quad

Turner others 1980 Geothermal resources Alaska $R, F E, F E, F W$

$\mathrm{R}, \mathrm{Fs}, \mathrm{HS}$

HS, $R, F B$

Gr
Fs
Gr

R,Fs

Ophir $\quad S C-1$

Anonymous 1975 Ak regional proflles Sw reglon C

Baker \& others 1977 Geotherm springs-salmon hatchery site R,DP,Fs

Berry \& others 1980 Thermal spring list U.S.

$\mathbf{R}$

Decker \& others 1984 Geol data Russian Mission A-3 Quad

Gr

Gassaway \& Abramson 1977 Map \& table thermal springs cntr Ak R,Fs

Hoare \& Coonrad 1959 Geol map Russian Mission Quad Gr

Markle 1979 Geotherm Ak site data base \& devel status R,Fs,Gr,C Motyka \& others 1983 Geothermal resources of Alaska R, Fs, Ff, Fw

Robinson \& Decker 1986 Ages \& analysis from SW Alaska Gr,PG

Robinson \& others 1984 Bdrck geol Chuilnuk \& Klokluk Mts [abs] $G r$

Robinson a others 1986 Rocks from sleetmute, Russian Mission Q PG

Turner \& others 1980 Geothermal resources Alaska

Waring 1965 Thermal springs US \& world - a summary

R, Fs

Fs

Partov Cove $A A-13$

Berry \& others 1980 Thermal spring 1 lst U.S.

Black 1974 Geol anclent Aleuts

Black 1974 Iate Quat sea level changes Umnak Is

Black 1975 Iate Quat geomorph Umnak Is

Black 1976 Geol Umnak related to Aleuts

Brook \& others 1979 Hydrothermal systems $<90$ deg

Byers 1959 Geol Umnak \& Bogoslof Islands

Byers 1961 Petro 3 volc suites Umnak \& Bogoslof Islands

Byers \& Brannock 1949 Volc activity Umnak \& Great Sitkin Is

$\mathbf{R}$

Markle 1979 Geotherm Ak site data base devel status R,Fs,Gr,C Motyka \&oorman 1981 Recon thermal spr Aleutlan arc R,Fs,Ff Motyka \& others 1981 Assmt thermal spring Aleutlan arc R,Fs,Ff, Gr Motyka others 1983 Geothermal resources of Alaska R,Fs,Ff,Fw

Muffler 1979 Assmt geothermal resources U. S. $R, F s$, HS

Reeder \& others 1980 Ak. geothermal program

DP 
Turner \& others 1980 Geothermal resources Alaska

R, Fs

Paviov $\quad$ AA-3I

Berry \& others 1980 Thermal spring list U.S.

Davidson 1893 Eruption of Veniaminof

Decker 1967 Invest at active volcanoes

Kennedy \& Waldron 1955 Geol Pavlof volcano

Kienle 1976 Seismic monitoring Pavlov

Ialla Kienle 1975 Microquakes, tremors at Pavlov [abs.]

McNutt 1983 Activity Paviov Shumagin gap? [abs.]

McNutt 1984 Eruption \& stress Paviov [abs.]

McNutt \& Beavan 1981 Quakes at Paviov earth tides

McNutt \& Beavan 1984 Pavlov sea level \& aseismic slip [abs.]

McNutt \& Mori 1983 B type quakes Pavlov [abs.]

Motyka \& others 1981 Assmt thermal spring Aleutian arc R,Fs,Ff,Gr Motyka \& others 1983 Geothermal resources of Alaska R,Fs,Ff,Fw

Powers 1953 Activity Aleut volcanoes

Prosser 1912 volcanic road-building

Shackelford 1983 Hist activity Paviov Volc

stone \& Rienle 1975 Pavlov

Warling 1965 Thermal springs Us \& world - a summary

White \& W11liams 1975 Assmt geothermal resources US

Woodruff \& Anderson 1980 Arrested magma mixing Pavlov

$\mathbf{H}, \mathbf{R}$

V

Gr

$\mathrm{V}, \mathrm{Ps}$

Ps, V

$\mathbf{V}$

$\mathbf{V}$

$\mathbf{v}$

V

$\mathbf{V}$

Pilgrim NC-1, NC-2

Berry \& others 1980 Thermal spring list U.S.

Bliss $1983 \mathrm{Ak}$ basic data thermal springs \& wells

Brook \& others 1979 Hydrothermal systems $<90$ deg

R, Fs, FW

R, Fs

Bunker \& others 1977 Prelim radio ages of rocks Kigluaik Mts Gr

Buzzell \& Gibson 1986 Nome-Taylor Rd. cultural resources

Dean \& others 1981 Remote sensing Pilgrim Springs

C

Economides \& Arce 1983 Geothermal in Ak - eng \& geol anal EF,Er

Economides \& others 1982 Eng,geol anal geothermal sites EF,Er

Economides \& others 1982 Reservoir eng analysis Pilgrim Sprg Er

Forbes 1979 Geol, geoph assmt of geotherm pot Pilgrim HS Gs, Ps

Forbes \& Biggar 1973 Ak geothermal resource potential

Forbes \& others 1975 Geophysical recon Pilgrim Springs

Forbes \& others 1975 Utilization geothermal rural Ak

Forbes \& others 1975 Utilization geothermal rural Ak

Fs, DP, Ef

Forbes others 1975 Utilization of Alaska thermal springs DP

Forbes * others 1979 Geol, geoph assmt geothrm pot Pilgrim Gs,Ps

Forbes o others 1979 Pilgrim springs hydrothermal system RM

Gosink \& Osterkamp 1980 Prelim invest hot water Pllgrim River HS

Harrison \& Hawkins 1980 Water \& heat flow Pilgrim HS

HS, DP

Hawkins \& Harrison 1979 Flow rate Pilgrim HS [abs.]

HS, DP

Homan 1972 Energy from the earth

Hopkins \& Hopkins 1958 Seward Peninsula

Hudson 1977 Geol map Seward Penin

Hudson \& Plafker 1978 KIgluaik \& Bendeleben faults

Kienle \& Lockhart 1979 Selsm \& grav survey P1lgrim HS [abs.] R, DP

Kienle \& Lockhart 1980 Gravity survey P1lgrim geotherm area

Kline 1980 Test drilling Pilgrim 1979

Gr

Gr

Gr

Ps

Ps

Er 
Kline 1981 surf geol Pilgrim vicinity

KIIne others 1980 surf geol drilling pilgrim Hs

Kunza \& Lofgren 1983 Pilgrim HS expl, drill, \& testing

Lockhart 1981 Gravity survey central seward Penin.

Er

Lockhart \& Kienle 1980 Selsm \& grav survey Pligrim spr KGRA Ps

Lofgren 1983 Geotherm devel Pilgrim springs DP, Gs, Ps

Iongenkamp \& others 1974 Elec resist survey Pilgrim springs Ps Markle 1979 Geotherm Ak site data base \& devel status R,Fs,Gr,C Markle 1979 Geothermal energy devel Pilgrim HS

DP

Miller $1972 \mathrm{~K}$ rich intrusive rocks $\mathrm{W}$ Ak

PG

Miller 1973 Distribution chem analysis thermal springs Ak R,Fs Miller \& others 1972 Prelim geol map Solomon \& SE Bendeleben $Q$ Gr Miller others $1975 \mathrm{Geol}$ \& chem hot springs $W$ cent Ak R,Fs Motyka o others 1980 Geochemistry Pilgrim thermal waters Fs, Fw Motyka \& others 1983 Geothermal resources of Alaska : R,Fs,Ff,FW Muffler 1979 Assmt geothermal resources U. S. R,Fs, HS Nichols \&eeder 1983 Ak geothermal \& hydrotherm development R,DP Ogle 1976 Ak. hot spring site for smali binary plant R,DP,Fs osterkamp \& others 1979 Conduct \& hydrol meas P1Igrim HS [abs] Ps Osterkamp \& others 1980 Recon study access power P1lgrim PB,Gs,DP Reeder \& others 1980 Ak. geothermal program

Robinson \& Stevens 1983 Geol map Seward Penin

DP

Robinson \& Stevens 1984 Geol map Seward Penin

stefano 1974 Low temp use Pligrim HS

stefano 1975 Pllgrim HS could heat Nome

Stern \& stirling 1982 P1Igrim Hot Springs Road

Gr

Swanson \& others 1980 Bedrock geol Pilgrim springs area

Gr

Turner \& Forbes 1980 Geol geophy stdy Pilgrim *,Gs, Ps, RM, Fs, Fw, HS

Turner \& Swanson 1981 Continent rifting new model Seward Pen $G r$

Turner \& others 1979 Geol tect setting Pilgrim spr [abs.] Gs

Turner \& others 1980 Geothermal resources Alaska

Turner \& others 1980 Sum geol geophys invest Pilgrim spr

Turner \& others 1981 Continent rifting new model seward Pen

Waring 1917 Mineral springs Ak

Waring 1917 Mineral springs Ak

Waring 1965 Thermal springs US \& world - a summary

R,Fs

RM

Gr

DP

Wescott 1981 He \& Hg cent Seward Penin

Fs, R

Fs, R

Wescott \& Turner 1981 Geotherm recon C Seward Pen Gs,Ps,Gc,HS, RM

Wescott \& others 1979 Resis survey Pligrim HS [abs.] Ps

Wescott \& others 1980 Resis survey PIIgrim spr area Ps

White \& Williams 1975 Assmt geothermal resources US R,Fs, HS

Woodward-Clyde 1983 Geothermal development P1Igrim spr DP

Pocahontas NC-18

Berry \& others 1980 Thermal spring 1 ist U.S.

BIIss $1983 \mathrm{Ak}$ basic data thermal springs \& wells

Cass 1959 Recon geol map Melozitna $Q$ Ak.

Markle 1979 Geotherm Ak site data base \& devel status R,FG,Gr,C

Miller 1970 Petro plutonic rocks W central Ak

Miller 1971 petro plutonic rocks $W$ cent Ak (thesis)

M1ller others 1966 Prelim plutonic belt $W$ cent Ak

Motyka \& others 1983 Geothermal resources of Aláska

Patton 1973 Recon geology N Yukon-Koyukuk 
Patton \& others 1978 Geol map Melozitna Q Silberman \& others 1978 Age of rocks Ruby, Medfra \& adj Q Turner \& others 1980 Geothermal resources Alaska

Port Moller AA-32

Baker \& others 1977 Geotherm springs-salmon hatchery site R,DP,Fs Berry \& others 1980 Thermal spring list U.S. Bliss 1983 Ak basic data thermal springs \& wells Coats 1956 Recon geol W Aleutian Islands $R, F s, F w$ LYle \& Dobey 1974 Geol evaluation Herendeen Bay area Gr Markle 1979 Geotherm Ak site data base devel status R,Fs,Gr,C Miller 1973 Distribution \& chem analysis thermal springs Ak R,Fs Motyka \& Moorman 1981 Recon thermal spr Aleutian arc Motyka \& others 1981 Assmt thermal spring Aleutian arc R,Fs,Ff, Gr Motyka \& others 1983 Geothermal resources of Alaska R,Fs,Ff, FW Okada \& Okada 1974 Hot springs village Port Moller Okada \& Okada 1980 Hot springs site Port Moller Okada \& others 1976 Hot springs village Port Moller Okada \& others 1979 Hot springs village Port Moller Peale 1886 Mineral springs of US Reed \& others 1983 Data low temp geothermal systems us Turner \& others 1980 Geothermal resources Alaska Waring 1917 Mineral springs Ak Waring 1965 Thermal springs Us \& world - a summary

Red Hill spring NC-36

Bader 1984 Geol map eastern N. slope Ak. Bader \& Bird 1986 Geol map NE Alaska Berry \& others 1980 Thermal spring list U.S. Bliss $1983 \mathrm{Ak}$ basic data thermal springs \& wells Imm 1986 Geol \& strat Mt Michelson quads Markle 1979 Geotherm Ak site data base \& devel status Meigs 1986 structural evol Sadlerochit Mts. Motyka \& others 1983 Geothermal resources of Alaska Reed \& others 1983 Data low temp geothermal systems Us Rogers 1986 Geology Shublik Mts

Redoubt , SC-13

Capps 1935 Southern Alaska Range

Decker 1967 Invest at active volcanoes

Detterman \& Hartsock 1966 Geol Iniskin-Tuxedni region

Detterman \& others $1976 \mathrm{Geol}$ map by faults in Renal \&yonek $Q \mathrm{Gr}$ Johnson 1979 Volc gas studies Ak volcanoes

$R, F f$ Kienle \& Swanson 2983 Volc E Aleut arc I Quat \& Holo cntrs V,PG Kienle \& Swanson 1983 Volc E Aleut arc Quat \& Holo centers V,PG Martin \& Katz $1910 \mathrm{GeOl}$ \& min resources Il Iamna \& Lake Clark $\mathrm{H}, \mathrm{Gr}$ Motyka \& others 1983 Geothermal resources of Alaska R,Fs,Ff,FW Page \& others 1982 Seism Spurr, Redoubt, \& Illamna [abs.] Prosser 1912 Volcanic road-building Riehle 1985 Recon Holo tephra deposits upper Cook Inlet Riehle \& others 1981 Lahars Crescent River Lower Cook Inlet 
Till 1984 Redoubt-strat \& volc hazards [abs.]

White \& Williams 1975 Assmt geothermal resources US

$E g, P G$

Wilcox 1959 Volcanic ash fails Alaska

W1lson \& Forbes 1969 Infrasonic waves \& Volc erupt [abs.]

Wilson \& Forbes 1969 Infrasonic waves Ak volc eruptions

Yount 1984 Redoubt mineralogy \& chem [abs.]

Reed River NC-15

Adams 1983 Geol northern Arrigetch pluton (thesis) Gr

Adams 1984 Geol northern Arrigetch Peaks pluton [abs.] Gr

Anonymous 1982 Reed River Hot Springs F\&

Berry \& others 1980 Thermal spring list U.S. $R$

Brook \& others 1979 Hydrothermal systems <90 deg R,Fs

Brosge \& Pessel 1977 Prelim recon geol map survey Pass Q Gr

Markie 1979 Geotherm Ak site data base \& devel status R,Fs,Gr,C

Miller 1973 Distribution \& chem analysis thermal springs Ak R,Fs

Motyka \& others 1983 Geothermal resources of Alaska R,FB,Ff, Fw

Muffler 1979 Assmt geothermal resources U. S. R,Fs,HS

Nava Morrison 1974 Note on hot springs interior Ak

Nelson \& Grybeck 1978 Arrigetch Peaks \& Igikpak plutons

R,Fs

stoney 1900 Naval expl Alaska

Turner \& Others 1980 Geothermal resources Alaska

waring 1917 Mineral springs Ak

Waring 1965 Thermal springs US \& world - a summary

Gr

$\mathrm{H}, \mathrm{Gr}$

R,Fs

Fs, R

Fs

Seguam AA-9

Berry \& others 1980 Thermal spring list U.S. $R$ Markile 1979 Geotherm Ak site data base \& devel status R,Fs,Gr,C Miller 1973 Distribution \& chem analysis thermal springs Ak R,Fs Miller \& Barnes 1974 Geotherm devel Ak [abs.]

Miller \& Barnes 1976 Geotherm develop Ak summary $D P, G r, V$ Motyka others 1981 Assmt thermal spring Aleutian arc R,Fs,Ff, Gr Motyka others 1983 Geothermal resources of Alaska R, Fs, Ff, FW Peale 1886 Mineral springs of us

Smith \& Shaw 1979 Igneous related geothermal systems

Turner \& others 1980 Geothermal resources Alaska

Waring 1965 Thermal springs US \& world - a summary

White \& Williams 1975 Assmt geothermal resources US

Semisopochno1 AA-2

Ach \& DeLong 1980 Magma evo L. Sitkin \& Semisopochnol [abs.] PG

Coats 1956 Recon geol w Aleutian Islands $\quad$ Gr

Coats 1959 Geol recon Semisopochnol Island Gr G

Lewis others 1960 Geol Rat Islands, Aleutlans Gr

Markle 1979 Geotherm Ak site data base devel status R,Fs,Gr,C

Miller \& Barnes 1974 Geotherm devel Ak [abs.]

H1ler \& Barnes 1976 Geotherm develop AK summary

Motyka o others 1983 Geothermal resources of Alaska

Smith \& Shaw 1979 Igneous related geothermal systems

Turner \& others 1980 Geothermal resources Alaska H, R $\mathrm{R}, \mathrm{HS}$ R,Fs Fs

$R, F s$, HS

Waring 1965 Thermal springs US \& world - a summary $D P, G r ; V$ $D P, G r, V$ R, Fs, Ff, Fw $R$, HS R,Fs Fs 
White \& Williams 1975 Assmt geothermal resources US

R, Fs, HS

Serpentine NC-3

Berry \& others 1980 Thermal spring list U.S. BIIss 1983 Ak basic data thermal springs \& wells

Brook \& others 1979 Hydrothermal systems <90 deg

Collier 1902 Recon NW Seward Penin

Forbes \& others 1975 Utilization geothermal rural Ak

Hopkins \& Hopkins 1958 Seward Peninsula

Hudson 1977 Geol map Seward Penin

Hudson 1977 zoned granite stock Seward Penin

Hudson 1977 zoned granite stock Seward Penin. (thesis)

Hudson 1979. Ig \& meta rocks Serpentine HS area

Markle 1979 Geotherm Ak site data base \& devel status R,Fs, Gr,C Milier 1973 Distribution chem analysis thermal springs Ak R,Fs Miller \& others 1975 Geol \& chem hot springs W cent Ak Motyka others 1983 Geothermal resources of Alaska Muffler 1979 Assmt geothermal resources U. S. R, Fs Nehring \& others 1979 sulfate geotherm western U. S. Ogle 1976 Ak. hot spring site for small binary plant Robinson \& Stevens 1983 Geol map seward Penin Robinson \& Stevens 1984 Geol map Seward Penin $R, F s, F E, F W$ Sainsbury \& others 1968 Sno2 Humbolt Cr Serpentine-Rougarok Gr Sainsbury \& others $1970 \mathrm{Geol} \mathrm{min}$ dep geochem \& rad serpentine $\mathrm{Gr}$ Turner \& others 1980 Geothermal resources Alaska Waring 1917 Mineral springs Ak Waring 1965 Thermal springs Us \& world - a summary

White \& W11liams 1975 Assmt geothermal resources US $R, F s$ Fs, R $R, F S, H S$ R, Fs R, DP, Fs Gr

Shishalain AA-24

- Brown 1899 Shishaldin - Decker 1967 Invest at active volcanoes Fournelle \& Marsh 1986 Shishaldin lavas [abs.] R, FS, HS

Markle 1979 Geotherm Ak site data base \& devel status $R, F G, G r, C$ Motyka \& others 1983 Geothermal resources of Alaska Powers 1953 Activity Aleut volcanoes Prosser 1912 Volcanic road-bullding Westdahl 1900 Mountains on Unimak White \& Williams 1975 Assmt geothermal resources Us *

Snowy Mt. $\quad S C-8$

Allen zles 1923 Chem study fumaroles Katmai region $R, F \boldsymbol{F}, \mathrm{F}, \mathrm{FW}$ $\mathrm{H}, \mathrm{V}$ $R, F E, H S$

¥Berg \& Keinle 1966 Gravity meas Katmai volc area Berg \& others 1967 Crustal structure - Ratmal Bordet \& others 1963 Katmai

Decker 1964 Geophys investigations Katmai [abs.]

Griggs 1919 Katmai \& VTIS

Kelier 1955 Geol Katmal [abs.]

Keller \& Relser 1959 Geol Katmai

Kienle 1968 Gravity Survey Katmai (thesis)

Kienle 1969 Gravity traverse VTrS, Katmai [abs.] 
Kienle \& Swanson 1983 Volc E Aleut arc $I$ Quat \&olo cntrs

Kienle \& Swanson 1983 Volc E Aleut arc Quat \& Holo centers

Klenle \& others 1981 Volcanlc centers Ratmal [abs.]

Kosco 1981 Andesitic tolcanism at Katmal

Kosco 1981 Edgecumbe volc \& Katmal (thesis)

Kubota \& Berg 1967 Magma in Katmal range

MacGregor 1952 Eruptive mechanisms VTTS

Matumoto 1971 Selsm body waves Ratmal \& molten chmbr [abs.] Pr,V

Matumoto \& Ward 1967 Microquake study Katma1

Miller \& Barnes 1974 Geotherm devel Ak [abs.]

Miller \& Barnes 1976 Geotherm develop Ak summary

Morris 1985 Katmal Park draft management plan

Nuller \& others 1954 Volcanlc activity Katmal

Reck 1930 Review VTTS (Ger)

Rubenstone \& others 1985 Isot \& trace elem Katmai [abs.]

Shipley 1919 VTTS

Smith 1925 Cold Bay Ratmal dist

Smith Baker 1924 Cold Bay-Chignik dist

Swanson \& Rienle 1982 Volc ceriters Ratmal

White *illiams 1975 Assmt geothermal resources US

$$
\begin{array}{r}
\mathrm{Pr}, \mathrm{V} \\
\mathrm{DP}, \mathrm{Gr}, \mathrm{V} \\
\mathrm{DP}, \mathrm{Gr}, \mathrm{V} \\
\mathrm{C}, \mathrm{DP} \\
\mathrm{V} \\
\mathrm{H}, \mathrm{V} \\
\mathrm{PG} \\
\mathrm{H} \\
\mathrm{Gr}, \mathrm{H} \\
\mathrm{Gr}, \mathrm{H} \\
\mathrm{V}, \mathrm{Gr} \\
\mathrm{R}, \mathrm{Fs}, \mathrm{HS}
\end{array}
$$

South NC-10

Berry \& others 1980 Thermal spring list U.S.

BIIss 1983 Ak basic data thermal springs \& wells

Brook \& others 1979 Hydrothermal systems $<90$ deg

$R, F B, F W$

Gassaway \& Abramson 1977 Map \& table thermal springs

Markle 1979 Geotherm Ak site data base devel status

Miller 1970 Petro plutonic rocks $W$ central Ak

Miller 1971 Petro plutonic rocks $w$ cent Ak (thesis)

PG

M1ller $1972 \mathrm{~K}$ rich intrusive rocks W Ak

PG

Miller 1973 Distribution \& chem analysis thermal springs Ak R, Fs

Miller others 1966 Prelim plutonic belt $w$ cent Ak

Miller \& others 1975 Geol chem hot springs $W$ cent Ak R, Fs

Motyka \& others 1983 Geothermal resources of Alaska R,Fs,Ff,Fw

Muffler 1979 Assmt geothermal resources $U . S . \quad$ R,Fs, HS

Patton \& others 1968 Reg geol map Shungnak \& Ambler River $Q$ Gr

Reed others 1983 Data low temp geothermal systems US HS,R,Fs

Rosenbruch Bottge 1975 Econ potent 3 sites Ak

Turner \& others 1980 Geothermal resources Alaska

White \& Williams 1975 Assmt geothermal resources Us

R, Fs

R,Fs, HS

Summer BaY $A A-19, A A-20$

Beebee Kirkwood 1979 Unalaska-geothermal prospects

Berry \& others 1980 Thermal spring list U.S.

Bliss 1983 Ak basic data thermal springs \& wells

Boyd \& Jacob 1984 Selsmicity of Unalaska

Dames \& Moore 1980 Geothermal drilling studies unalaska

Drewes \& others 1961 Geol Unalaska adjacent shelf

Economides \& Arce 1983 Geothermal in Ak - eng \& geol anal

Economides others 1981 Unalaska geothermal development

Economides \& others 1982 Eng,geol anal geothermal sites

Jacob \& Boyd 1985 Seismic network on Unalaska 
Lankford \& Hill 1979 Strat \& depos envirn Dutch Harbor member Gr Markle 1979 Geotherm Ak site data base \& devel status R,Fs,Gr,C Miller 1973 Distribution \& chem analysis thermal springs Ak R,Fs Motyka \& Moorman 1981 Recon thermal spr Aleutian arc R,Fs,Ff Motyka \& others 1981 Assmt thermal spring Aleutian arc R,Fs,Ff,Gr Motyka \& others 1983 Geothermal resources of Alaska R,Fs, Ff, FW Peale 1886 Mineral springs of US $\mathrm{H}, \mathrm{R}$ Reeder 1981 Initial assmt hydrotherm Summer Bay Unalaska Er,Gs Reeder 1982 Hydrothermal resources N Unalaska Is Rosenbruch \& Bottge 1975 Econ potent 3 sites Ak Turner \& others 1980 Geothermal resources Alaska Wescott \& others 1981 Geophys survey Summer Bay Wescott \& others $1982 \mathrm{He} \& \mathrm{Hg}$ survey parts Unalaska

Fs, Ff EF R, Fs Ps Gc

sun Mt. NC-14

Cass 1959 Recon geol map Melozitna $Q$ Ak. Gr Gassaway \& Abramson 1977 Map \& table thermal springs cntr Ak R,Fs Markle 1979 Geotherm Ak site data base \& devel status R,Fs,Gr,C Miller 1970 Petro plutonic rocks $W$ central Ak PG Miller 1971 Petro plutonic rocks $W$ cent Ak (thesis) PG Miller 1973 Distribution \& chem analysis thermal springs Ak R,Fs Miller \& others 1966 Prelim plutonic belt $W$ cent Ak Gr Miller \& others 1975 Geol \& chem hot springs W cent Ak R,Fs Motyka \& others 1983 Geothermal resources of Alaska R,Fs,Ff,Fw Patton 1973 Recon geology N Yukon-Koyukuk Patton \& others 1978 Geol map Melozitna Q Silberman \& others 1978 Age of rocks Ruby, Medfra \& adj $Q$ Turner \& others 1980 Geothermal resources Alaska

Tanaga

Coats \& Marsh 1984 Recon geol \& petrol N Tanaga [abs.] Gr Turner \& others 1980 Geothermal resources Alaska R, Fs

Tatlawiksuk $\quad s C-22$

Blodgett \& Glibert 1983 Cheeneetnuk Iimestone Mc Grath Bundtzen Gilbert 1983 Geology upper Kuskokwim Bundtzen Kline 1986 Coal, peat \& geotherm in Kuskokwim Cady \& others 1955 Geology central Kuskokwim Decker 1984 Kuskokwim group Decker \& Hoare 1982 Cretaceous Kuskokwin Group

Dickey 1983 Tertiary seds \& tectonics Farewell fault area Dickey \& others 1982 Cenozoic seds \& Farewell fault Gilbert 1981 Geologic map Cheeneetnuk River area

Tenakee SE-5, SE-6

Berry \& others 1980 Thermal spring list U.S. Bl1ss 1983 Ak basic data thermal springs \& wells Buddington \& Chapin 1929 Geol \& mineral deposits SE AK Economides Arce 1983 Geothermal in Ak - eng \& geol anal Economides \& others 1982 Eng,geol anal geothermal sites 
Knopf 1912 sitka mining district H, Gr Loney \& others 1963 Geol Freshwater Bay Chichagof Is Gr Loney \& others 1963 Recon geol map Chichagof \& NW Baranof Is Gr Ioney \& others 1967 Radio ages \& fault movements N SE AK Gr Ioney \& others 1975 Recon geol Chlchagof, Baranof \& Rruzof Is Gr Markie 1979 Geotherm Ak site data base \& devel status R,Fs,Gr,C Miller 1973 Distribution chem analysis thermal springs Ak R,Fs Motyka \& Moorman 1987 Geotherm resourcers SE Ak R, Fs, FW Motyka \& others 1983 Geothermal resources of Alaska R,Fs,Ff, Fw Nava 1975 Note on hot springs SE Ak Reed \& others 1983 Data low temp geothermal systems US Reeder \& others 1980 Ak. geothermal program Rosenthal 1908 Hot springs of southeast Alaska Rossman 1959 Geol \& ore dep NW ChIchagof Is Turner others 1980 Geothermal resources Alaska Twenhofel \& Sainsbury 1958 Fault patterns SE Ak Waring 1917 Mineral springs Ak Waring 1965 Thermal springs US \& world - a summary White \& Williams 1975 Assmt geothermal resources Us wright 1906 Nonmetallic deposits SE Ak.

R, Fs HS , R, Fs DP $\mathrm{H}, \mathbf{R}$ Gr R,Fs Gr

Fs, R Fs R,FG, HS $\mathbf{G r}, \mathbf{H}$

Tenakee Inlet SE-3

Berry \& others 1980 Thermal spring 11st U.S. Bliss 1983 Ak basic data thermal springs wells Brook \& others 1979 Hydrothermal systems $<90$ deg Buddington \& Chapin 1929 Geol \& mineral deposits SE Ak Knopf 1912 sitka mining district Ioney \& others 1963 Recon geol map Chlchagof \& NW Baranof Is Gr Ioney \& others 1967 Radio ages \&ault movements $N$ SE Ak Gr Ioney \& others 1975 Recon geol Chichagof, Baranof \& Kruzof Is Gr Markie 1979 Geotherm Ak site data base devel status R,Fs,Gr,C Miller 1973 Distribution chem analysis thermal springs Ak R,Fs Motyka \& Moorman 1987 Geotherm resourcers SE Ak R, Fs, FW Motyka \& others 1983 Geothermal resources of Alaska Muffler 1979 Assmt geothermal resources U. S. Nava 1975 Note on hot springs SE AK Rosenthal 1908 Hot springs of southeast Alaska Rossman 1959 Geol \& ore dep NW Chlchagof Is Turner \& others 1980 Geothermal resources Alaska Twenhofel \& Salnsbury 1958 Fault patterns SE AK Waring 1917 Mineral springs Ak Waring 1965 Thermal springs US \& world - a summary White Will lams 1975 Assmt geothermal resources Us R,Fs,Ff, FW $R, F s$, HS R,Fs $\mathbf{H}, \mathbf{R}$ Gr R, Fs Gr Fs, R F6 R, Fs, HS

TetIIn NC-40

Carter Galloway 1978 Geol map proposed gas IIne Gr Foster 1970 Recon geol map Tanacross Quad

Gr 
Tolovana: NC-3I

Berry \& others 1980 Thermal spring 11st U.S. Bliss 1983 Ak basic data thermal springs \& wells Brook \& others 1979 Hydrothermal systems $<90$ deg

Forbes \& others 1975 Utilization geothermal rural Ak

Foster others 1970 Geol Yukon-Tanana upland [abs.]

Foster \& others 1973 Geology Yukon-Tanana upland

Gassaway \& Abramson 1977 Map \& table thermal springs cntr Ak R,Fs Markle 1979 Geotherm Ak site data base \& devel status R,Fs,Gr,C Mertie 1932 Yukon Tanana region Gr Mertie 1934 Mineral deposits Rampart \& Hot Springs district $G r$ Miller 1973 Distribution \& chem analysis thermal springs Ak R,Fs Miller \& others 1975 Geol \& chem hot springs $W$ cent Ak R,Fs Motyka \& others 1983 Geothermal resources of Alaska R,Fs,Ff, Fw Muffler 1979 Assmt geothermal resources U. S. Nava \& Morrison 1974 Note on hot springs interior Ak Turner \& others 1980 Geothermal resources Alaska Waring 1917 Mineral springs Ak Waring 1965 Thermal springs US \& world - a summary White \& Williams 1975 Assmt geothermal resources US $R, F s$, HS R,Fs R, Fs Fs, R Fs

Tunalkten Lake NC-19

- Berry \& others 1980 Thermal spring list U.S. Forbes \& others 1975 Utilization geothermal rural Ak Fs,DP,Ef Gassaway \& Abramson 1977 Map \& table thermal springs cntr AK R,Fs Markle 1979 Geotherm Ak site data base \& devel status R,Fs,Gr,C Miller 1970 Petro plutonic rocks $\mathrm{W}$ central Ak Miller 1971 Petro plutonic rocks $W$ cent Ak (thesis) PG Milier 1973 Distribution chem Miller \& others 1966 Prelim plutonic belt $W$ cent $A k$ Gr Miller \& others 1975 Geol chem hot springs W cent Ak R,Fs Motyka o others 1983 Geothermal resources of Alaska R,Fs,Ff,Fw Patton 1973 Recon geology N Yukon-Koyukuk Patton \& Miller 1966 Regional geol map Hughes $Q$ Turner \& others 1980 Geothermal resources Alaska

Win Lakes SE-12

(2)

Berry \& others 1980 Thermal spring list U.S. Bliss $1983 \mathrm{Ak}$ basic data thermal springs wells $\quad$ R, Fs, Fw Brew others 1984 Geologic map Peterbrg, Sumdum, P. Alex Gr Budaington \& Chapin 1929 Geol \& mineral deposits SE AK Gr Kerr 1948 stikine \& Iskut River area BC, Canada Gr Markle. 1979 Geotherm Ak site data base devel status R,Fs,Gr,C Motyka \& Moorman 1980 Assmt thermal spring S SE Ak [abs.] R, Fs Motyka \& Moorman 1987 Geotherm resourcers SE Ak R, Fs, FW Motyka \& others 1980 Assmt therm spr S SE Ak Motyka \& others 1983 Geothermal resources of Alaska R,Fs,Ff,Fw Turner \& others 1980 Geothermal resources Alaska R,Fs Wright \& Wright 1908 Retchikan \& Wrangell mining districts $G r, H$ 
Ukinrek AA-37

Barnes McCoy 2979 Mantle-derived CO2 in 2 phreatic expl Fs,Ff,V Berry others 1980 Thermal spring list U.S s*

Detterman \& others $1983 \mathrm{Geol}$ map Ugash1k-Bristol Bay-Karluk Q Gr

Detterman \& others 1985 Geol map Ugashik \& $W$ Rarluk $Q$ Gr

Detterman others 1986 Quat map Ugashik-Bristol Bay-Karluk Q Gr

Kienle \& Swanson 1983 Volc E Aleut arc I Quat \& Holo cntrs V,PG

Kienle \& Swanson 1983 Volc E Aleut arc Quat \&olo centers V,PG

Klenle \& others 1978 Form. 2 mars behind volc arc [abs.] V

Kienle others 1978 Formation 2 maars Ak Penin prelim results V

Kienle \& others 1980 Ukinrek Maars 1977 eruption V

Lecompte 1981 Prelim map Landsat Ugashik \& Karluk $Q \quad$ Gr

Lorenz 1982 Eruption UkInrek Maars $v$

Miller 19842 stage volcanism Ugashik-Peulik [abs.] PG

Motyka \& others 1981 Assmt thermal spring Aleutian arc R,Fs,Ff;Gr Motyka \& others 1983 Geothermal resources of Alaska R,Fs,Ff,Fw

Self others 1978 Mechanisms \& deposits Ukinrek [abs.] Ps,Gs,V

self others 1980 Ukinrek Maars II deposits formation $v$

Smith Baker 1924 Cold Bay-Chignik dist Gr,

Turner \& others 1980 Geothermal resources Alaska R, Fs

Upper Division NC-11

Gassaway \& Abramson 1977 Map \& table thermal springs cntr Ak R,Fs

Miller 1970 Petro plutonic rocks W central Ak

- Miller 1971 Petro plutonic rocks $W$ cent Ak (thesis) PG

Milier $1972 \mathrm{~K}$ rich intrusive rocks $\mathrm{W}$ Ak PG

Milier \& others 1966 Prelim plutonic belt $W$ cent Ak Gr

Motyka \& others 1983 Geothermal resources of Alaska R,Fs,Ff, Fw

Nava \& Morrison 1974 Note on hot springs interfor Ak R, Fs

Patton \& others 1968 Reg geol map Shungnak Ambler River Q Gr

Rosenbruch Bottge 1975 Econ potent 3 sites Ak EF

Upper Klawasi SC- 17

AGS 1975 Drum thermal springs area $\quad$ DP

Andreasen \& others 1958 Aeromag Copper River basin $\mathrm{Pr}$

Andreasen \& others 1964 Geol inter mag \& grav Copper Rvr basn $\mathrm{Pr}$

Berry others 1980 Thermal spring list U.S.

Bliss 1983 Ak basic data thermal springs wells $R, F s, F w$

Church \& others 1970 Copper RIver basin strat correl section Gs

Economides \& Arce 1983 Geothermal in Ak - eng \& geol anal EF,Er

Economides \& others 1982 Eng,geol anal geothermal sites EF, Er

Emery Jones 1984 Hydrologic atlas Copper River basin Gs

EmmeI coonrod 1982 Geol Literature copper RIver basin Gr

Ferrians \& Nichols 1965 Copper River basin $\quad$ Gr

Ferrians \& Schmoll 1957 Wlsc progalclal lake Copper River bsn $\mathrm{Gr}$

Ferrians o others 1958 Plelst volc mudflow copper River basin $V$

Ferrians \& others 1983 Copper River basin $\quad$ Gr

Foresman 1968 Photogeol \& geomorph Copper River basin Gs

Foresman 1970 Mud volcanoes Copper River basin (thesis) Gs

Grantz others 1962 Saline springs Copper River basin Fs

Hawkins \& Motyka 1985 stat \& chem anal H2O Copper River bsn Fs, Fw 
Henning others 1981 Wrangell-st Elias Wilderness C Markle 1979 Geotherm Ak site data base \& devel status R,Fs,Gr,C Mendenhall 1903 Mineral resources Mt Wrangell district H, Gr -Mendenhall 1905 Geology central Copper River region H,Gr "Motyka \& others 1983 Geothermal resources of Alaska R,Fs,Ff,Fw \$Motyka \& others 1986 Geochem lsot org mud volc Copper R Fs,Ff, Fw wichols \& Yehle 1961 Anal gas \& water Copper River basin Fs Nichols \&ehle 1961 und volc Copper River basin Nichols \& Yehle 1969 Eng geol map SE Copper River basin Reed \& others 1983 Data low temp geothermal systems US Reeder \& others 1980 Ak. geothermal program Reltsema 1979 Gases of mud volc Copper River basin Richter \& others 1979 Geol map Gulkana A-2 Q stoltzfus 1982 Copper River basin planning study Turner \& others 1980 Geothermal resources Alaska Fs Gs HS , R, Fs FP Turner \& others 1983 Sum, eval gthrm exp copper R bsn Gs, Ps, Fs, RM Wescott \& Turner 1983 Geotherm expl E copper R basin Ps,Gc,Fs,Fw Wescott \& Turner 1983 Geotherm potent Copper R basin Gs, Ps,Gc,DP Wescott \& Turner 1985 Geotherm invest Copper *, Gs, Ps, Gc, DP, Fs, Fw Williams 1985 Eng geol map Copper River basin

Yehle others 1985 Geol frm drilling in copper R. basin Gr

Upper Noatak NC-38

Brosge \& Pessel 1977 Prelim recon geol map Survey Pass Q Gr

Upper RaY NC-24

Berry \& others 1980 Thermal spring 11st U.S. $\mathbf{R}$ Bliss 1983 Ak basic data thermal springs \& wells R, Fs, Fw Chapman \& others 1975 Prelim geol map Tanana \& NE Rantishan Q Gr Chapman \& others 1982 Recon geol map Tanana $Q$ Dover \& Mayaoka 1985 Rocks Ray Mts, Tanana \& Bettles $Q$ Gr Gassaway \& Abramson 1977 Kap table thermal springs ontr Ak $R$ Markle 1979 Geotherm Ak site data base \& devel status R,Fs,Gr,C Milier 1973 Distribution \& chem analysis thermal springs Ak R, Fs Miller \& others 1975 Geol \& chem hot springs W cent Ak R,Fs Motyka \& others 1983 Geothermal resources of Alaska R,Fs,Ff,Fw Nava \& Morrison 1974 Note on hot springs interior Ak Rs *atton \& Miller 1970 Prelim geol invest Kanut1 isilberman \& others 1978 Age of rocks Ruby, Medfra \& adj $Q$ -Turner \& others 1980 Geothermal resources Alaska

Gr

R, Fs

Veniaminof

*

Davidson 1893 Eruption of Ventaminof Hubbard 1931 Geol Aniakchak \& Venlaminof [abs.] Smith \& Shaw 1979 Igneous related geothermal systems

White Mt. SC-24

Bundtzen \& Gilbert 1983 Geology upper Kuskokwim Bundtzen \& Kline 1986 Coal, peat \& geotherm in Kuskokwim Cady \& others 1955 Geology central Kuskokwim 
Decker 1984 Kuskokwim group Gr

Decker \& Hoare 1982 Cretaceous Kuskokwim Group Gs

Dickey 1983 Tertiary seds \& tectonics Farewell fault area Gs,PG

Dickey 1984 Cenozolc rocks Farewell area $/$ Gr

DLckey \& others 1982 Cenozolc seds \& Farewell fault Gr

Gilbert 1981 Geologic map Cheeneetnuk River area Gs

Gilbert \& Solle 1983 Prelim geol map Mc Grath A-3 Quad Gr

Solle 1983 Plutons in Mc Grath A-3 Quad Gs

White sulfur $\quad S E-1$

Berry \& others 1980 Thermal spring Iist U.S.

Bl1ss 1983 Ak basic data thermal springs \& wells

Brook \& others 1979 Hydrothermal systems <90 deg

Buddington \& Chapin 1929 Geol \& mineral deposits SE Ak

$R, F s, F w$

R, Fs

Decker 1980 Geol Cret. subduct complx Chlchagof Is (thesis) Gr

Decker 1980 Geol map $w$ Chichagof Island

Gr

Knopf 1912 sitka mining district

$\mathbf{H}, \mathbf{G r}$

Ioney others 1963 Recon geol map Chichagof NW Baranof Is Gr

Ioney \& others 1967 Radio ages \& fault movements $N$ SE AK

Ioney \& others 1975 Recon geol Chichagof, Baranof \& Rruzof Is Gr Markle 1979 Geotherm Ak site data base devel status R,Fs,Gr,C Martin 1917 Mineral resources of Ak. $\quad H, G r$ Miller 1973 Distribution \& chem analysis thermal springs AK R,Fs Motyka \& Moorman 1987 Geotherm resourcers SE AK R, Fs, Fw Motyka \& others 1983 Geothermal resources of Alaska R,Fs,Ff,Fw Muffler 1979 Assmt geothermal resources U. S. Nava 1975 Note on hot springs SE Ak

Rossman 1959 Geol \& ore dep NW Chichagof Is Turner others 1980 Geothermal resources Alaska Twenhofel \& Sainsbury 1958 Fault patterns SE Ak Waring 1917 Mineral springs Ak

Waring 1965 Thermal springs Us \& world - a summary

White \& Williams 1975 Assmt geothermal resources US

$R, F S, H S$

R, Fs

Gr

R, Fs

$\mathbf{G r}$

Fs, R

Fs

R, FE, HS

Willow SC-15

Capps 1935 Southern Alaska Range

Gr

Detterman \& others 1976 Geol map by faults in Kenal \& Tyonek Q Gr Motyka others 1983 Geothermal resources of Alaska R,Fs,Ff, Fw Reger 1978 Recon geol capital site

Gr

Reger \& Carver 1978 Recon geol materials map capital site Gr

Still 1980 Index water qual records to 1978

Turner * Wescott 1982 Prelim invest gthrm I Susitna

Wescott \& Witte 1982 Gravity survey I susitna basin

Gs, Ps, Gc, HS

Ps 


\section{ALASKA GEOTHERMAL BIBLIOGRAPHY}

SECTION IV

ADDITIONAI REGIONAL LISTING

(see Table I - Abbreviations used in short references - Pg. 223) (see Table II - Codes used in short references - Pg. 227)

(see Figures for geothermal region locations - Pgs. 233-243) 


\section{Alaska Peninsula}

Beaglehole 1967 Joumals of Captain James Cook Burk 1965 Geol Ak Penin-island arc \& continental margin Capps 1934 Notes geol Ak Penin Aleutian Islands Case \& others 1980 Tertlary volc centers Ak Penin. Davydov 1809 voyages to Russian America 1802-1807 Doroshin 1870 volcanoes, eruptions earthquakes Dumond 1979 People pumice Ak Penin. Estes 1978 Selsmotectonlc studies lower cook Inlet (thesis) Grewingk 1850 Historlc geology NW North America (Ger) Hansen others 1981 Mineral potential Ak Penin. Henning \& others 1976 Alaska's volcanoes Hubbard 1935 Cradle of storms Kienle 1974 Alaskan volcano studies esp. Augustine Kienle Forbes 1974 Ak volc studies Augustine Kienle others 1983 Magmatism subduction E Aleutian arc Miller \& Sith 1975 Ak geothermal study Miller Smith 1975 Ash flows Ak Penin prelim rpt [abs.] Miller \& Smith 1983 Calderas E Aleutian arc [abs.] Nakamura \& others 1977 Volc tectonic stress orlent Aleut \& $A K R, V$ Perrey 1866 Quakes volcanism Aleutians \& Ak Penin (Fr) Powers 1956 Activity AK volcanoes 1949-53

Powers 1958 Ak. Penin Aleut Is Pulpan \& Kienle 1978 Selsmic \& volcanic risks, Alaska

Reed Lanphere 1973 Ak-Aleut bathol1th, geochron \& chem Reed \&anphere 1973 Plutonic rocks Ak-Aleut batholith Shelikhov 1790 Voyage to Amerlca $1783-1786$ Simkin others 1981 volcanoes of the World smith \& others 1978 Data \& therm energy est young ig sys US Spurr 1900 Recon in SW AK 1898 wilson o others 1985 Alaska Peninsula terrane Workman 1979 signif volc in prehlst of subarctic

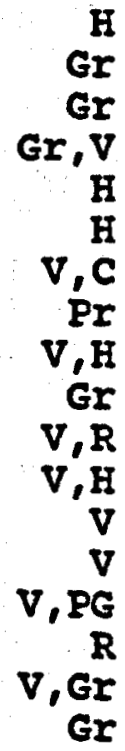

Aleutians

Beaglehole 1967 Journals of Captain James cook

Black 1980 Movements sea level Aleutian Is

Black 1981 Late Quat climatic changes Aleutian Islands

Black 1983 Glacial chronology Aleutians

Burk 1965 Geol Ak Penin-island arc continental margin

Capps 1934 Notes geol Ak Penin \& Aleutian Islands

Coats 1950 Volc activity Aleutian arc

Coats 1962 Magma type \& crustal structure Aleutian arc

Davydov 1809 Voyages to Russlan Amerlca 1802-1807

Doroshin 1870 Volcanoes, eruptions \& earthquakes

Edsall 1976 Trace elem in tephra Aleutlans

Grewingk 1850 Historic geology NW North America (Ger)

Henning others 1976 Alaska's volcanoes

Erdilcka 1945 Aleutian Is inhabitants

Hubbard 1935 Cradle of storms

Jaggar 1908 Technical expedition to Aleutians

Kay \& Kay 1982 Aleut volc rock, primitive magmas [abs.]

Kay others 1982 Tectonic control of magmatism Aleut arc 
Rienle 1969 Gravity in the Aleutians [abs.]

Kienle 1974 Alaskan volcano studies esp. Augustine

Kienle \& Forbes 1974 Ak volc studies Augustine

Kienle \& others 1981 Subd \& magma $E$ Aleut arc [abs.]

Kienle others 1983 Magmatism subduction E Aleutian arc

Marsh 1974 Aleutian arc magmatism (thesis)

Marsh 1982 Aleutians - orogenic andesites

Miller \& Smith 1983 Calderas E Aleutian arc [abs.]

Morgan 1980 Aleutians

Motyka $1982 \mathrm{High}$ temp hydrotherm Aleutian arc [abs.]

R, Fs, Ff

Nakamura \& others 1977 Volc tectonic stress orient Aleut \& Ak $R, V$

Perrey 1866 Quakes \& volcanism Aleutians \& Ak Penin (Fr)

Powers 1956 Activity AK volcanoes 1949-53

Powers 1958 Ak. Penin Aleut Is

Reed Ianphere 1972 Geol map Ak-Aleut batholith $\mathrm{K} / \mathrm{Ar}$ ages

Reed \& Ianphere 1973 Ak-Aleut batholith, geochron \& chem

Reeder 1982 Hydrotherm potential Aleut arc - Makushin [abs]

Scheidegger \& Kulm 1973 Cyclic Aleut volc ash DSDP 178 [abs.]

Scheldegger \& others 1977 Ash volc Aleut \& Ramchat arc [abs.]

Shelikhov 1790 Voyage to America 1783-1786

Simkin \& others 1981 Volcanoes of the World

Smith \& others 1978 Data \& therm energy est young ig sys Us

stewart 1975 Late Cenozoic erupt Aleutians \& Kuril Is arcs

Wilson \& Turner 1975 Rad age map Aleutians

Workman 1979 signif volc in prehist of subarctic

Gr

Gr

DP

Interior

- Beikman \& Lathram 1975 Prelim geol map N Ak

Eberlein \& others 1977 Prelim geol map central Alaska

Gr

Gr

Northern

Beikman \& Lathram 1975 Prelim geol map N Ak

Blanchard \& Tailleur 1982 Prelim geothermal isograd map NPRA

Lachenbruch \& others 1984 Geotherm Prudhoe Bay

Wilson \& Turner 1975 Rad age map N AK

Gr

HS

HS

Gr

Seward Peninsula

Hopkins \& Hopkins 1958 Seward Peninsula

Gr

Hudson 1977 Geol map Seward Penin

Gr t

soputh Central

Beikman 1974 Prelim geol map SE Quad of Alaska

Belkman 1974 Prelim geol map sw Quad Alaska

Davydov 1809 Voyages to Russian America 1802-1807

Shelikhov 1790 Voyage to Amerlca 1783-1786

Wilson 1977 Plutonic rocks SW Ak data compilation

$\mathrm{H}, \mathrm{C}$
$\mathbf{V}, \mathbf{R}$

Wilson \&urner 1975 Rad age map SC Ak

Wilson \& Turner 1975 Rad age map SW Ak

Gr

Gr

Gr 


\section{South East}

Beikman 1975 Prelim geol map SE Alaska

Grewingk $1850 \mathrm{Historic}$ geology NW North America (Ger)

Monger \& Berg 1985 Terrane map SE AK. \& W. Can.

Gr

W11son \& Turner 1975 Rad age map SE Ak

Southeastern Quadrant

Belkman 1974 Prelim geol map SE Quad of Alaska

Schrader \& Spencer 1901 Geol \& min res Copper River dist

Wilson \& Turner 1975 Rad age map SC Ak

$\mathbf{H}, \mathbf{G r}$

Gr

Southwestern Quadrant

Beikman 1974 Prelim geol map sw Quad Alaska

Spurr 1900 Recon in SW Ak 1898

W1Ison 1977 Plutonic rocks SW Ak data compilation

Wilson \& Turner 1975 Rad age map SW Ak

$\mathrm{H}, \mathrm{Gr}$

Gr

Gr

statewide

* Barnes \& M1ller 1974 Geotherm studies in Alaska [abs.]

Barnwell \& Pearson 1984 Ak resource inventory

Basecu 1980 Geothermal in Alaska

Beikman 1980 Geologic map of Alaska

Blackwell \& steele $1986 \mathrm{NA}$ geothermal map [abs.]

Conwell \& Schell 1977 Energy resource map Alaska

- Dall 1870 Alaska and its resources

* Fitch 1927 Mineral waters of the U.S.

Forbes 1975 Geothermal energy \& wind power

Forbes \& Blggar 1973 Ak geothermal resource potential

Forbes \& others 1975 Utilization of Alaska thermal springs

Godwin others 1971 Classif of public land for geothermal

Hickel 1972 National proposal for geothermal research

Homan 1972 Energy from the earth

Johnson \& Hartman 1969 Environmental atlas of Ak

Jones \& others 1984 Terrane map Alaska

Lawver \& others 1979 Reglonal heat flow Ak

Leonard 1975 Geothermal energy

Mariner \& others 1978 Data for hydrothermal systems $>=90$

Miller \& Barnes 1974 Geotherm devel Ak [abs.]

Miller \& Barnes 1976 Geotherm develop Ak summary

Miller \& Smith 1975 Ak geothermal study

Nathenson \& others 1983 Reglonal heat flow

Pewe 1975 Quaternary geology of Ak

Reeder \& others 1980 Geothermal implementation plan

R,Fs

DP

$\mathbf{R}$

Gr

R, HS

$\mathbf{R}$

H

H

$R, D P$

$R$, HS

DP

$R, D P$

DP

$R, D P$

C

Gr

HS

$\mathbf{R}$

R, Fs $D P, G r, V$ $D P, G r, V$

Sammel 1979 Low temp. geothermal in U.S.

Simkin others 1981 Volcanoes of the World

Taber 1972 Selsmicity geotherm areas Ak \& other (thesis)

Turner others 1975 Rad dates Ak 1975 compllation

Wanek 1973 Geotherm areas by meridian \& acreage

Wescott * Turner 1982 Geotherm assmt parts of Ak

Gr, $\mathbf{R}$

$R$, HS

Gr

DP

R

$\mathbf{V}, \mathbf{R}$

$\mathrm{R}, \mathbf{P r}$

Gr

$\mathbf{R}$

$R, G s, P s, G c$ 
AIASKA GEOTHERMAL BIBLIOGRAPHY

SECTION V

SUBJECT LISTING

(see Table I - Abbreviations used in short references - Pg. 223)

(see Table II - codes used in short references - Pg. 227) 
Cultural, socio-economic data, environmental studies $C$

Anonymous 1975 Ak regional profiles SW region

Beebee \& Kirkwood 1979 Unalaska-geothermal prospects

Buzzell \& Gibson 1986 Nome-Taylor Rd. cultural resources

Davies \& Kienle 1986 Augustine eruption \& advice [abs.]

Dumond 1979 People \& pumice Ak Penin.

Henning \& others 1981 Wrangell-st Ellas wilderness

Holmes 1986 Archaelogical evaluation Makushin

"Hralicka 1945 Aleutian Is \& inhabitants

Jackson 1880 Alaska \& its missions

Johnson \& Hartman 1969 Environmental atlas of AK

Markle 1979 Geotherm Ak site data base \& devel status

Meaker 1908 Tanana Valley

Morgan 1980 Aleutians

Morris 1985 Katmai Park draft management plan

Okada O Okada 1974 Hot springs village Port Moller

Okada Okada 1980 Hot springs site Port Moller

Okada \& others 1976 Hot springs village Port Moller

Okada \& others 1979 Hot springs village Port Holler

Petrov 1884 Alaska population \& resources

Shelikhov 1790 Voyage to America 1783-1786

stern \& Stirling 1982 Pilgrim Hot springs Road

Stoltzfus 1982 Copper River basin planning study

Workman 1979 Signif volc in prehist of subarctic

$c$

Development \& planning DP

AGS 1975 Drum thermal springs area DP Baker \& others 1977 Geotherm springs-salmon hatchery site R,DP,Fs Barnwell \& Pearson 1984 Ak resource inventory DP Barnwell \&earson $1984 \mathrm{Ak}$ resource inventory DP Bundtzen \& Kline $1986 \mathrm{Coal}$, peat \& geotherm in Kuskokwim R,DP Carey \& others 1983 Unalaska geotherm land, regs, \& environ DP Denig-Chakroff \& others 1985 Development pot Mak reservoir Er,DP Economides others 1981 Unalaska geothermal development DP Forbes 1975 Geothermal energy \& wind power R,DP Forbes \& others 1975 Utilization geothermal rural Ak FG,DP,Ef Forbes \& others 1975 Utilization of Alaska thermal springs DP Godwin \& others 1971 Classif of public land for geothermal R,DP Harrison \& Hawkins 1980 water \&eat flow Pilgrim HS

Hawkins \& Harrison 1979 Flow rate P1lgrim HS [abs.]

Hickel 1972 National proposal for geothermal research

Homan 1972 Energy from the earth

Krause 1986 Power \& road corridor study Makushin

Iofgren 1983 Geotherm devel Pilgrim springs

Markle 1979 Geothermal energy devel pilgrim HS

Miller \& Barnes 1974 Geotherm devel Ak [abs.]

Miller \& Barnes 1976 Geotherm develop Ak summary

Morris 1985 Katmal Park draft management plan

HS, DP

HS, DP

DP

$R, D P$

$E g, P s, D P$ DP, Gs, Ps

DP, Gr, V Motyka \& others 1985 Geol geoc geophys Akutan *,Gs,Fs, Ps, RM, Ff,DP Nichols \& Reeder 1983 Ak geothermal \& hydrotherm development $R, D P$ Ogle $1976 \mathrm{Ak}$. hot spring site for small binary plant R,DP,Fs Osterkamp others 1980 Recon study access power Pilgrim Ps,Gs,DP 
Reeder 1982 Hydrotherm potential Aleut arc - Makushin [abs] DP Reeder 1982 Hydrothermal Iesources Makushtin region DP Reeder \& others 1980 Ak. geothermal program \& DP Reeder others 1980 Geothermal implementation plan DP Reeder \& others 1982 Econ \& eng geoth develop Makushin EF,Eg,DP Republ1c 1982 Unalaska Gtrml Proj IA Er,Hs,Fs, Ff, Gs, Ps, DP,RM, HA Republ1c 1983 Unalaska Gtrml Proj IB Er,HS,Fs, Ff,Gs, Ps, DP, RM, HA Republ1c 1984 Unalaska Gtrml Proj II Er,HS,Fs, Fw, Gs, Ps, DP, RM, HA Republic 1985 Unalaska Gtrml Proj III *,Er,Hs,Fw,Gs,Ps, DP,RM, HA Spencer \& others 1982 Anal geothrm res devel Unalaska EF,DP stefano 1974 Low temp use Pilgrim HS stefano 1975 P1Igrim HS could heat Nome DP Updike 1986 Eng geol, feasibil study Makushin * Eg,Gs,Ps,Fs, DP Wescott \& Turner 1983 Geotherm potent Copper $R$ basin Gs, Ps, GC,DP Wescott \& Turner 1985 Geotherm invest Copper *, Gs, Ps, Gc, DP, Fs, Fw Woodward-Clyde 1983 Geothermal development Pilgrim spr DP

Economic feasibility studies EF

Beebee KIrkwood 1979 Unalaska-geothermal prospects Denig-Chakroff 1985 Unalaska recon study C,EF Economides \& Arce 1983 Geothermal in Ak - eng \& geol anal Economides others 1982 Eng,geol anal geothermal sites Forbes others 1975 Utilization geothermal rural Ak Reeder \& others 1982 Econ \& eng geoth develop Makushin Rosenbruch \& Bottge 1975 Econ potent 3 sites Ak Spencer \& others 1982 Anal geothrm res devel Unalaska

Engineering geology, hazard studies

$\mathbf{E g}$

\section{Arce 1983 Volcanic hazards Makushin Volcano (thesis)}

Arce \& Economides 1982 Volcanic hazards Makushin Volcano Combellick 1986 Eng geol power plant site Makushin Davies 1986 Selsmic hazards - Makushin Economides others 1985 Eval Makushin geothermal reservoir Eg, Ps Emanuel 1984 Hydro \& volc hazards Mt spurr [abs.] Eg Johnson o others 1977 Augustine Volc, evaluat hazards [abs.] V,Eg Jones 1986 Coastal engineering - Makushin

Kienle \& Swanson 1980 . Volcanlc hazards Augustine

Kienle \& Swanson 1985 Volc hazards Augustine 2nd ed.

Krause 1986 Power road corridor study Makushin

Iong 1986 Glacial hazard Makushin

March 1986 Avalanche hazards-Makushin

Nye 1986 Volcanic hazards, Makushin

Pulpan \& Kienle 1978 Selsmic \& volcanic risks, Alaska

Reeder 1986 Ground stability, spring water Broad Bay

$\mathbf{E g}$

Reeder \& others 1982 Econ \& eng geoth develop Makushin

$\mathbf{V}, \mathbf{E g}$

$\mathrm{V}, \mathrm{Eg}$

Till 1984 Redoubt-strat \& volc hazards [abs.]

Updike 1986 Construction materials Makushin

Upalke 1986 Eng geol, feasibil study Makushin

Williams 1985 Eng geol map Copper RIver basin

*,Eg, Gs, Ps, Fs, Dg

$\mathrm{Eg}, \mathrm{Fs}, \mathrm{Gs}$

$E F, E g, D P$

$E g, P G$

Eg 
Exploration geochemistry GC

Matlick \& Parmentier $1983 \mathrm{Hg}$ soll survey Makushin GC,Fs,Ff queen 1987 Alt, H2O-rock equil, Makushin (thesis) HA, FW, Gs, Gc,HS Turner \& Wescott 1982 Prelim invest gthrm I Susitna Gs,Ps,Gc,HS Turner \& Wescott 1986 Geotherm invest Mt. Spurr $\star, R, P s, G C, V, G s, R M$ Turner o others $1986 \mathrm{Hg}$ and He surveys Mt. Spurr Gc, R Wescott 1981 He \& Hg cent seward Penin Wescott 1981 He $\mathrm{Hg}$ surveys Chena HS Wescott Turner 1981 Geol geophys Chena HS Wescott \& *, Gs, Ps, GC Thescott \& Turner 1981 Geotherm recon c seward Pen wescott \& Turner 1982 Geotherm assmt parts of Ak R,Gs,Ps,GC Wescott \& Turner 1983 Geotherm expl E Copper R basin Ps,GC,Fs,Fw Wescott \& Turner 1983 Geotherm potent Copper R basin Gs, Ps,Gc,DP Wescott \& Turner 1985 Geotherm Invest Copper *,Gs, Ps, Gc, DP, Fs, Fw Wescott \& others $1982 \mathrm{He} \& \mathrm{Hg}$ survey parts Unalaska GC Wescott \& others 1985 Prelim rept gthrml invest Mt Spurr Gs,Ps,Gc Wiltse 1986 Radon hazard assessment Circle HS

Gc

Final report, for areas with numerous interim reports

*

Motyka \& others 1985 Geol geoc geophys Akutan *,Gs, Fs, Ps, RM, Ff,DP

= Motyka \& others 1986 Makushin well chem equilib *,Fw, Fs, Ff, HA, RM Nye \& others 1986 Petro geochem Quat volc Makushin *,V,Gs, PG Republic 1985 Unalaska Gtrml Prof III *,Er,HS, Fw, Gs, Ps, DP, RM, HA Turner \& Forbes 1980 Geol geophy stdy Pllgrim *,Gs, Ps, RM, Fs, Fw, HS Turner \& Wescott 1986 Geotherm Invest Mt. Spurr *,R, Ps, GC,V,Gs, RM Updike 1986 Eng geol, feasibil study Makushin *,Eg,Gs,Ps,Fs,DP Wescott \& Turner 1981 Geol \& geophys Chena HS *,Gs,Ps, GC

- Wescott \& Turner 1985 Geotherm invest Copper *,Gs, Ps, Gc, DP, Fs, Fw

-Fumarole chemistry Ff

Allen \& zies 1923 Chem study fumaroles Ratmal region Ff Barnes \& MCCOY 1979 Mantle-derived CO2 in 2 phreatic expl FE,Ff,V Barnes \& McCoy 1979 Mantle-derived CO2 in 2 phreatic expl Fs, Ff,V Chaigneau \& Bordet 1963 Gas in glass in VTTS (Fr) Harmon \& others 1982 Isotopes from Augustine fumaroles Johnson 1979 Volc gas studies Ak volcanoes Johnson 1980 Volc contr Cl to stratosphere sKodosky \& Keskinen 1986 Fumarole alt Augustine [abs.] Lovering 1957 Halogen-acid alteration VTTS Matlick \& Parmentler $1983 \mathrm{Hg}$ soll survey Makushin Menyaylov 1969 Comparison Bezymyany \& Ratmai (Rus) $P, \mathbf{V}$ Ff R, Ff $V$, Ff $\mathrm{HA}, \mathrm{Ff}, \mathrm{V}$ HA, Ff 'Motyka 1982 Fluld geochem Makushin \& Akutan geotherm area Ff, Fs Motyka 1982 Fluid geochemistry of Makushin Motyka Motyka Motyka $1982 \mathrm{High}$ temp hydrotherm Aleutian arc [abs.] FE, Ff Motyka 1983 Geochem \& 1sotope study water \& gas Makushin $R, F s, F f$ Motyka 1984 chem of water Motyka \& Moorman 1981 Recon thermal spr Aleutian arc Motyka \& Queen 1984 Makushin fluids samps \& well log Fs,Ff,FW,PG Motyka others 1981 Assmt thermal spring Aleutian arc R,Fs,Ff,Gr 
Motyka \& others 1982 Fluid geochem Hot Springs Akutan Fs, Ff Motyka \& others 1982 Fluid geochemistry Makushin area Fs,Ff Motyka \& others 1983 fliuld investigations Makushin area Fs, Ff Motyka others 1983 Geothermal resources of Alaska R,Fs,Ff,Fw Motyka * others 1985 Geol geoc geophys Akutan *, Gs, Fs, Ps, RM, Ff,DP Motyka \& others 1986 Augustine gas sampling [abs.] Ff Motyka \& others 1986 Geochem isot org mud volc Copper $R$ Fs,Ff,Fw Motyka \& others 1986 Makushin well chem equilib *,Fw,Fs,Ff, HA, RM Poreda \& others 1981 He 1sot vars Ak-Aleut arc [abs.] R,Fs, Ff Reeder 1981 V-D hydrotherm maifest Unalaska [abs.] Gs, Ff Reeder 1982 Hydrothermal resources N Unalaska Is Fs, Ff Republic 1985 Unalaska Gtrml Proj III *,Er,HS,Fw,Gs,Ps,DP, RM, HA Shipley 1920 Chem obs VTTS Shipley 1920 Katmai gas \& encrustations Vige

Geology Gr, Gs

Adams 1983 Geol northern Arrigetch pluton (thesis) Gr Adams 1984 Geol northern Arrigetch Peaks pluton [abs.] Gr Andreasen \& others 1958 Aeromag Copper River basin $\mathrm{Pr}$ Andreasen \& others 1964 Geol Inter mag \& grav Copper Rvr basn Arce 1983 Volcanic hazards Makushin Volcano (thesis)

Pr Bader 1984 Geol map eastern N. slope Ak. Bader \& Bird 1986 Geol map NE Alaska Beget 1986 Prehistoric tephra at Augustine [abs.] Beikman 1974 Prelim geol map SE Quad of Alaska Belkman 1974 Prelim geol map SW Quad Alaska Belkman 1975 Prelim geol map SE Alaska Beikman 2980 Geologic map of Alaska Beikman \& Lathram 1975 Prelim geol map $N$ Ak Berg \& Hinckley 1963 Recon geol northern Baranof Is. Berg \& others 1978 Geol map Ketchikan \& Prince Rupert o Ak. Gr Blggar 1974 Geol geophys stdy at Chena HS (thes1s) Gs,Ps,Fs,Fw Black 1974 Geol * anclent Aleuts

Black 1974 Late Quat sea level changes Umnak Is

Black 1975 Late Quat geomorph Umnak Is

Black 1976 Geol Umnak related to Aleuts

Black 1980 Movements sea level Aleutian Is

Black 1981 Holo sea level changes Aleutlan Islands Black 1983 Glacial chronology Aleutians Blodgett Gilbert 1983 Cheeneetnuk IImestone Mc Grath Brew \& Ford 1985 Geol map Juneau, Taku, AtIIn, Skag Quad Brew \& others 1969 Recon geol Mt Edgecumbe Brew \& others 1984 Geologic map peterbrg, sumaum, P. Alex Brophy \& Marsh 1984 Petro \& geochem Cold Bay volc [abs.] Brosge \& Patton 1982 Bedrock geol maps Dalton Hwy Brosge \& Pessel 1977 Prelim recon geol map Survey Pass Q Buddington \& Chapin 1929 Geol \& mineral deposits SE Ak Bundtzen \& Gilbert 1983 Geology upper Kuskokwim $\mathbf{E g}$ Gr Gr $\mathrm{V}, \mathrm{Gs}$ Gr G Gr Gr Gr Gr Gr Bundtzen \& KIIne $1986 \mathrm{Coal}$, peat \& geotherm In Kuskokwim Bunker \& others 1977 Prelim radio ages of rocks Kigluaik Mts Gr Burk 1965 Geol Ak Penin-island arc \& continental margin Gr 
Byers 1959 Geol Umnak \& Bogoslof Islands Byers \& Barth 1948 Geol Akutan Island Gr Cady others 1955 Geology central Kuskokwim : Gr Capps 1934 Notes geol Ak Penin \& Aleutian Islands Gr Capps 1935 Southern Alaska Range

Carter \& Galloway 1978 Geol map proposed gas line

Case \& others 1980 Tertiary volc centers Ak Penin.

Cass 1959 Recon geol map Melozitna $Q$ Ak. Chapman others 1975 Prelim geol map Tanana NE Kantishan 0 Chapman \& others 1982 Recon geol map Tanana $Q$ Church \& others 1970 Copper River basin strat correl section Coats 1947 Geol N Adak Island

Coats 1947 Geol N Ranaga Is.

Coats 1950 Volc activity Aleutian arc

Coats 1953 Geol Buldir Island

Coats 1956 Geol N Adak Island

Coats 1956 Geol N Kanaga Island

Coats 1956 Recon geol W Aleutian Islands

Coats 1959 Geol recon Garelol Island

Coats 1959 Geol recon Semisopochnol Island

Coats \& Marsh 1984 Recon geol \& petrol N Tanaga [abs.]

Coats \& others 1961 Geol recon Kiska Island

- Collazzi \& Ireland 1986 Hydrology lower Kuskokwim basin

Collier 1902 Recon NW Seward Penin

Curtis 1955 Importance of Novarupta [abs.]

Curtis 1968 stratigraphy of ejecta 1912 eruption Katma1

Decker 1980 Geol Cret. subduct complx Chichagof Is (thesis)

Decker 1980 Geol map $W$ Chlchagof Island

Decker 1984 Kuskokwim group

Decker \& Hoare 1982 Cretaceous Kuskokwin Group

Decker \& others 1984 Geol data Russian Mission A-3 Quad

Decker \& others 1984 Geology sleetmute B-5 Quad

Detterman 1973 Geol map Il Lamna B-2 Quad Augustine Island

Detterman \& Hartsock 1966 Geol Iniskin-Tuxedni region

Detterman \& Reed 1964 Prelim geol map Iliamna-0

Detterman \& Reed 1968 Geol Iliamna $Q$

Detterman \& Reed 1973 Surficlal deposits Illamna $Q$

Detterman \& Reed 1980 strat, struct, econ geol Iliamna $Q$

Detterman \& others 1976 Geol map by faults in Renal \& Tyonek $Q \mathrm{Gr}$

Detterman \& others 1979 Geol map Chignik \& Sutwik Is $Q$ Gr

Detterman \& others 1981 Geol map Chignik \& Sutwik Is Q Gr

Detterman others 1981 Quat geol map Chignik \& Sutwik Is $Q$ Gr

Detterman \& others 1983 Geol map Ugashik-Bristol Bay-Karluk Q Gr

Detterman \& others 1985 Geol map Ugashik \& $W$ Karluk $Q$ Gr

Detterman \& others 1986 Quat map Ugashik-Bristol Bay-Karluk \& Gr

Dickey 1983 Tertiary seds \& tectonics Farewell fault area Gs, PG

Dickey 1984 Cenozoic rocks Farewell area

Dickey \& others 1982 Cenozoic seds \& Farewell fault

Diller 1884 Volcanic sand Unalaska

Dillon \& others 1983 Geol map Melozitna A-4 Quad

Dover \& Mayaoka 1985 Rocks Ray Mts, Tanana \& Bettles $Q$

Drewes \& others 1961 Geol Unalaska \& adjacent shelf

Eakins 1969 sulfur deposit stepovak Bay [abs.]

East 1982 Geotherm investigation Manley HS (thesis) Fs,Fw,Gs,Ps 
Eberlein others 1977 Prelim geol map central Alaska Gr Eberlein \& others $1983 \mathrm{Geol}$ map Craig Q

Gr Economides \& Arce 1983 Geothermal in AK, eng \& geol anal .EF,Er Edsall 1976 Trace elem in tephra Aleutlans Eickelberger \& Hildreth 1986 Drilling in Katmai [abs.] Emery \& Jones 1984 Hydrologic atlas Copper River basin Emmel \& Coonrod 1982 Geol Iiterature Copper River basin Escher 1922 Lahar VTrS

Federman \& Scheldegger 1984 Distal tephra 1912 Novarupta

Fenner 1920 Geol Katmal 1912 eruption [abs.]

Fenner 1930 Mt Katma1 \& Mt Mageik

Fenner 1937 Tuffs of Katma1 \& Yellowstone Ferrians Nichols 1965 Copper River basin Ferrlans \& Schmoll 1957 WIsc progalclal lake Copper River bsn Gr Ferrians others 1983 Copper River basin V, Gs, Ps Ps Gs Gr $\mathrm{V}, \mathrm{H}$ $V$ $\mathrm{V}, \mathrm{H}$ $\mathrm{V}, \mathrm{H}$ $\mathrm{V}, \mathrm{H}$ Gr Flerstein \&ildreth 1984 Pyroclastic deposits Novarupta [abs.] V Forbes 1979 Geol, geoph assmt of geotherm pot Pilgrim HS Gs,Ps Forbes \& Kienle 1971 Petro pre 1912 pyroclast VTTS [abs] PG,Gs,V Foresman 1968 Photogeol geomorph Copper River basin Foresman 1970 Mud volcanoes Copper River basin (thesis) Gs Foster 1970 Recon geol map Tanacross Quad Foster \& others 1970 Geol Yukon-Tanana upland [abs.] Gr Foster others 1973 Geology Yukon-Tanana upland or Foster \& others 1983 Geologic map Circle $Q \quad$ Gr Foster others 1983 Prelim geol map Circle quad $\quad$ Gr Fraser \& Barnett 1959 Geol Delarof \& Andreanof Islands Gr Fraser \& Snyder 1959 Geol S Adak \& Kagalaska Islands Fry 1912 Mineral content volcanic ashes $\quad V, H$ Funk 1973 Iate quat geol cold Bay (thesis) Gr Funk 1973 Late Quat hist cold Bay [abs.] Gr Gassaway \& Abramson 1977 Map \& table thermal springs cntr Ak R,Fs Gates \& others 1971 Geol Near Islands

G1Ibert 1981 Geologic map Cheeneetnuk River area

Gilbert \& Solie 1983 Prelim geol map Mc Grath A-3 Quad

Griggs 1918 Eruption of Ratmal

Griggs 1922 VTTS

Griggs 1923 VTTS

Hansen \& others 1981 Mineral potential Ak Penin.

Herreid 1966 Geol \& geochem Inmachuk River

Higble 1975 VTTS

Hoare \& Coonrad 1959 Geol map Russian Mission Quad

Hopkins 1963 Imuruk Lake Seward Penin

Hopkins \& Hopkins 1958 Seward Peninsula

Hopkins \& Taber 1962 stratigraphy Manley HS

Hubbard 1931 Geol Aniakchak \& Veniaminof [abs.]

Hudson 1977 Geol map Seward Penin

Hudson $1979 \mathrm{Ig}$ \& meta rocks serpentine HS area

Gr

Gs

Gr

Hudson \& Plafker 1978 Kiglualk \& Bendeleben faults Gr

Imm 1986 Geol $\&$ strat Mt Michelson quads $\quad$ Gr

Jaggar 1908 Technical expedition to Aleutians

Johnson 1976 zoned magma chamber Augustine [abs.]

$\mathrm{V}, \mathrm{H}$

$\mathrm{V}, \mathrm{H}$

$\mathrm{V}, \mathrm{H}$

Gr

Gr 
Jones \& others 1984 Terrane map Alaska $\quad$ Gr

Juhle 1955 Illamna Volcano Gs

Keith 1984 Prelim obs fumaroles VTTS HA

Keith 1985 Hydrotherm alt Novarupta dome VTTS [abs.] HA

KReller 1955 Geol Katmal [abs.]. Gr

Keller \& Reiser 1959 Geol Katmal Gr

rennedy \& Waldron 1955 Geol Pavlof volcano

Kerr 1948 stikine \& Iskut River area BC, Canada Gr

Kienle Swanson 1983 Volc E Aleut arc Quat \& Holo centers V,PG

Kienle \& others 1970 seism evidence pre 1912 tuff VTrS [abs.] Gr

Kienle \& others 1980 Ukinrek Maars 1977 eruption V

Kline 1981 surf geol Pilgrim vicinity Gs

¿Knappen 1926 Geol \& min resources Aniakchak Gr

Knappen 1933 Aniakchak \& Veniaminof volcanoes [abs.] Gr, H

Knopf 1912 sitka mining district $\mathrm{H}, \mathrm{Gr}$

Lankford \& Hill 1979 Strat \& depos envirn Dutch Harbor member Gr

Lawton 1909 Makushin sulfur deposits Gs

Lecompte 1981 Prelim map Landsat Ugashik \& Karluk $Q \quad$ Gr

Lecompte \& Steele 1981 Map Iandsat Chignik \& Sutwik Is Q Gr

Lewis \& others 1960 Geol Rat Islands, Aleutians Gr

Loney \& others 1963 Geol Freshwater Bay Chichagof Is Gr

Ioney \& others 1963 Recon geol map Chichagof \& NW Baranof Is Gr

Ioney \& others 1964 Recon geol map Baranof \& Rruzof Is Gr

Ioney \& others 1967 Radio ages \& fault movements N SE AK Gr

Loney \& others 1975 Recon geol Chichagof, Baranof \& Rruzof Is Gr

Iovering 1955 Alteration near halogen-sulfur fumarole [abs.] HA

Lyle 1973 Geol \& mineral evaluation Aniakchak $R$ drainage $G r$

Iyle \& Dobey 1974 Geol evaluation Herendeen Bay area Gr

MacKevett 1976 Geol map McCarthy $Q \quad$ Gr

Mackevett 1978 Geol map McCarthy $Q \quad$ Gr

Markle 1979 Geotherm Ak site data base \& devel status R,Fs,Gr,C Marsh 1974 Aleutian arc magmatism (thesis) V,PG

Marsh 1980 Geol \& petrol N Atka Is [abs.] Gr

Martin 1917 Mineral resources of Ak. H,Gr

Martin \& Katz 1910 Geol \& min resources Iliamna \& Lake Clark H,Gr

Martin \& Katz 1912 Geol recon Iliamna Region H,Gr

Meigs 1986 structural evol Sadlerochit Mts. Gr

Mendenhall 1903 Mineral resources Mt Wrangell district $\mathrm{H}, \mathrm{Gr}$

Mendenhall 1905 Geology central Copper River region $\mathrm{F}, \mathrm{Gr}$

Menzie \& others 1983 Mineral assmt Circle quad

Merrill 1885 Hornblende andesites from Bogosloff H, Gs,PG

Mertie 1930 Geology Eagle-circle district Gr

Mertie 1932 Yukon Tanana region $\quad$ Gr

Mertie 1934 Mineral deposits Rampart \& Hot springs district Gr

Miller \& Barnes 1974 Geotherm devel AK [abs.] DP,Gr,V

Miller \& Barnes 1976 Geotherm develop Ak summary DP, Gr,V

Miller \& Smith 1975 Ash flows Ak Penin prelim rpt [abs.] $V, G r$

Miller \& Smith 19762 caldera forming eruptions Umnak $v$

Miller \& Smith 1976 Ash flows Wrangell volcano $v$

Miller \& Smith 1976 New volcanoes Aleutian arc v

Miller \& Smith 1983 Calderas E Aleutian arc [abs.] Gr

Miller \& others 1966 Prelim plutonic belt $W$ cent Ak Gr

Miller \& others 1972 Prelim geol map Solomon \& SE Bendeleben Q Gr

Miller \& others 1975 Geol \& chem hot springs W cent Ak R, Fs 
Moffit 1905 Fairhaven gold placers Seward Penin

$\mathrm{H}, \mathrm{Gr}$ Monger \& Berg 1985 Terrane map SE Ak. \& W. Can.

Gr Motyka \& Queen 1984 Makushin fluids samps well $10 \mathrm{~g}$ Fs,Ff,FW,PG Motyka o others 1981 Assut thermal spring Aleutian arc R,Fs,Ff, Gr Motyka \& others 1985 Geol geoc geophys Akutan *,Gs,Fs, Ps, RM,Ff,DP Myers others 1984 Assim crust by basalt magma Edgecumbe PG Nakamura \& others 1977 Volc tectonic stress orlent Aleut \& Ak R,V Nelson 1959 Geol Segula, Davidov, \&hvostov Islands Gr Nelson \& Grybeck 1978 Arrigetch Peaks \& Igikpak plutons Gr Nichols \&ehle 1969 Eng geol map SE Copper River basin Gs Nye Swanson 1986 Chem strat magma plumb Makushin [abs] V,Gs,PG Nye Swanson 1987 Makushin magma chamber Nye \&urner 1986 Geology \& geochemistry Spurr [abs.] Gs,PG,V Nye \& others 1984 Geol map Makushin geothermal area Nye \& others 1986 Petro geochem Quat volc Makushin $P G, G S, V$ Gs Osterkamp others 1980 Recon study access power P1lgrim Ps,Gs,DP Palache 1904 Geol Chichagof Cove, stepovak Bay Gr,H Parmentier \& others 1983 Geol \& hydrotherm alter Makushin Gs, HA Patton 1973 Recon geology N Yukon-Koyukuk

patton Hoare 1968 Kaltag Fault W-C Ak Patton \& Miller 1966 Regional geol map Hughes $Q \quad$ Gr

Patton \& Miller 1970 Prelim geol Invest Kanut1

- Patton others 1968 Reg geol map Shungnak Ambler RIver $Q$ Gr Patton \& others 1978 Geol map Melozitna Q

- Pavia 1986 structure \& strat okpilak batholith area Perrey 1866 Quakes \& volcanism Aleutians \& Ak Penin Pewe 1975 Quaternary geology of Ak Gr

Gr Queen 1987 Alt, H2O-rock equil, Makushin (thesis) HA, FW, Gs,GC,HS Ray \& others 1966 Petro \& geochem Mt Trident andesites [abs.] PG Reed \& Lanphere 1972 Geol map Ak-Aleut batholith $\mathrm{K} / \mathrm{Ar}$ ages Gr Reed \& Ianphere 1973 Ak-Aleut batholith, geochron \& chem Gr Reed \& Lanphere 1973 Plutonic rocks Ak-Aleut batholith

Reeder $1981 \mathrm{~V}-\mathrm{D}$ hydrotherm malfest Unalaska [abs.]

1983 Prellm dating Holo volcanto

Reeder 1984 Fault \& dike orientation Makushin [abs.] Gr Reeder others 1985 Geol geotherm resource Makushin R, Gs Reger 1978 Recon geol capital site

Reger \& Carver 1978 Recon geol materials map capital site

Relfenstuhl 1984 Crawfish Inlet Pluton Baranof Is [abs.] Gs, PG Reifenstuhl 1984 Geol \& geophys Goddard HS (thesis) Gs, Ps,Fs Relfenstuhl 1986 Geol Goddard Hot Springs Gs,Ps,Fs Republ1c 1982 Unalaska Gtrml Proj IA Er,Hs,Fs, Ff, Gs, Ps, DP, RM, HA Republic 1983 Unalaska Gtrml Proj IB Er,HS,Fs, Ff, Gs, Ps, DP, RM, HA Republ1c 1984 Unalaska Gtrml Proj II Er,HS,Fs,Fw, Gs, Ps, DP,RM, HA Republ1c 1985 Unalaska Gtrml Proj III *,Er,HS,Fw,Gs,Ps,DP, RM, HA Richter 1975 Geol map Nabesna $Q$

Richter 1976 Geol map Nabesna $Q$ Richter \& others 1979 Geol map Gulkana A-2 Q

Riehle 1985 Recon Holo tephra deposits upper cook Inlet Robinson \& Decker 1986 Ages \& analysis from SW Alaska Robinson \& Stevens 1983 Geol map Seward Penin Robinson \& Stevens 1984 Geol map Seward Penin

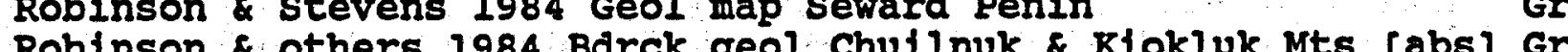
Robinson others 1984 Barck geol Chullnuk \& klokluk Mts [abs] Gr Robinson \& others 1984 Geologic map sleetmute B-5 Q 
Robinson \& others 1986 Geol map Mt. Michelson C-4 Quad

Gr

Roehn 1941 Pumice deposits Katmai

Rogers 1986 Geology Shublik Mts

Romick 1986 Ig pet and geochem N. Akutan

Gr

Rossman 1959 Geol \& ore dep NW Chichagof Is

Sainsbury \& others 1968 SnO2 Humbolt Cr Serpentine-Kougarok Gr

Sainsbury \& others 1970 Geol min dep geochem \& rad Serpentine Gr

Schnell \& Sheridan 1986 Arctic gas \& aerosols-Augustine [abs.] V

Schrader \& Spencer 1901 Geol \& min res Copper River dist $\mathrm{H}, \mathrm{Gr}$

;Self \& others 1978 Mechanisms \& deposits Ukinrek [abs.] Ps,Gs,V

\$ Silberman \& others 1978 Age of rocks Ruby, Medfra \& adj $Q$ Gr

Simons \& Mathewson 1955 Geol Great Sitkin Is

Smith 1925 Aniakchak Crater

Smith 1925 Cold Bay Katmai dist

Smith \& Baker 1924 Cold Bay-Chignik dist

Snyder 1959 Geol Iittle Sitkin Is

Snyder \& Fraser 1963 P1llowed lavas Unalaska

Solie 1983 Plutons in MC Grath A-3 Quad

Spurr 1900 Recon in SW Ak 1898

still 1980 Index water qual records to 1978 .

Stoney 1900 Naval expl Allaska

- Swanson \& Rienle 1982 Volc centers Ratmal

Swanson \& others 1980 Bedrock geol Pilgrim springs area

T111 1984 Redoubt-strat \& volc hazards [abs.]

Turner \& Nye 1986 Geochronology Mt. Spurr

Gr

$\mathrm{Gr}, \mathrm{H}$

Gr, H

$\mathbf{G r}, \mathrm{H}$

Gr

Gr

Gs

$\mathrm{H}, \mathrm{Gr}$

Gr

$\mathrm{H}, \mathrm{Gr}$

$\mathrm{V}, \mathrm{Gr}$

Gs

Eg, PG

Turner Swanson 1981 Continent rifting new model Seward Pen Gr Turner \& Wescott 1982 Prelim Invest gthrm I Susitna Gs, Ps, Gc, HS Turner \& Wescott 1986 Geotherm Invest Mt. Spurr *,R, Ps,GC,V,Gs, RM Turner \& others 1975 Rad dates Ak 1975 compilation

Turner \& others 1979 Geol \& tect setting Pilgrim spr [abs,]

Turner \& others 1981 continent rifting new model seward Pen Gr Turner \& others 1983 Sum, eval gthrm exp Copper R bsn Gs, Ps, Fs, RM Turner \& others 1986 Mt. Spurr geothermal project R,Gs,V Twenhofel \& Sainsbury 1958 Fault patterns SE Ak Gr Updike 1986 Eng geol, feasibil study Makushin *,Eg,Gs,Ps,Fs, DP

Waldron 1961 Geol recon Frosty Peak volc

Wescott \& Turner 1981 Geol \& geophys Chena HS

Wescott \& Turner 1981 Geotherm recon C Seward Pen Gs,Ps, GC,HS, RM

Wescott \& Turner 1982 Geotherm assmt parts of Ak R,Gs,Ps,GC

Wescott \& Turner 1983 Geotherm potent Copper R basin Gs,Ps,GC,DP

2Wescott \& Turner 1985 Geotherm invest Copper *,Gs, Ps,Gc, DP, Fs, Fw

Wescott \& others 1985 Prelim rept gthrml invest Mt spurr Gs,Ps,GC

W11liams 1955 Prelim geol Katmai \& VTTS

wilson 1977 Plutonic rocks SW AK data compilation

Gr

Wilson \& Shew 1981 Prelim $K-A r$ studies circle Q

*Wilson \& Turner $1975 \mathrm{Rad}$ age map Aleutians

Wilson \& Turner 1975 Rad age map N Ak

Wilson \& Turner 1975 Rad age map SC Ak

Wilson \& Turner 1975 Rad age map SE AK

Wilson \& Turner 1975 Rad age map SW Ak

Wilson \& others 1985 Alaska Peninsula terrane

Winkler \& others 1981 Folio Valdez $Q$

Woodward-clyde 1983 Geothermal development Pilgrim spr

Wright 1906 Nonmetallic deposits SE Ak.

Gr

Gr

Gr

Gr

Gr

Gr

Gr

Gr

Gr

DP

$G r, H$ 
Wright \& Wright 1908 Ketchikan \& Wrangell mining districts Gr,H Yehle others 1985 Geol frm drilling in copper R. basin Gr

Geophysics Pr, Ps

Allely 1986 Selsmic refraction Makushin Ps Andreasen \& others 1958 Aeromag Copper River basin $\quad$ Pr Andreasen others 1964 Geol Inter mag \& grav Copper Rvr basn Pr Anma 1971 Aeromag survey VTTS (thesis) Pr Barrett 1978 Magnetic model of Augustine Volcano (thesis) V,Ps Barrett o others 1977 Model of Augustine Volcano [abs.] V,Ps Berg \& Keinle 1966 Gravity meas Katmal volc area $\mathrm{Pr}$ Berg \& others 1967 Crustal structure - Ratmal Ps Biggar 1974 Geol \& geophys stdy at Chena HS (thesis) Gs, Ps,Fs, FW Boyd \& Jacob 1984 Seismicity of Unalaska $\mathrm{Pr}$ Corwin \& Fitterman 1983 Self potential Makushin geotherm area Ps Davies 1986 Seismic hazards - Makushin Eg,Ps Dean \& others 1981 Remote sensing Pilgrim Springs Ps Decker 1964 Geophys investigations Katma1 [abs.] Ps Dixon \& Pulpan 1986 Crustal structure-Dall City [abs.] Ps East 1982 Geotherm investigation Manley HS (thesis) Fs, FW, Gs,Ps East 1982 Prelim geothermal investigation Manley HS Gs,Ps,Fs Elckelberger \& Hildreth 1986 Drilling in Katmal [abs.] V,Gs,Ps Estes 1978 selsmotectonic studies lower cook Inlet (thesis). Pr Forbes 1979 Geol, geoph assmt of geotherm pot Pilgrim.HS Gs,Ps Forbes 1979 Geol, geoph assmt of geotherm pot Pilgrim HS Gs,Ps Forbes others 1971 Seismicity Augustine [abs.]

Forbes \& others 1975 Geophysical recon Pilgrim Springs

Forbes \& others 1979 Geol, geoph assmt geothrm pot Pilgrim Gs,Ps Gedney \& others 1970 Seismic refraction - Katmai

House others 1981 Selsmic gap near Unalaska

Jacob \& Boyd 1985 Seismic network on Unalaska

Kienle 1968 Gravity Survey Katmal (thesis)

Klenle 1969 Gravity in the Aleutians [abs.]

Kienle 1969 Gravity traverse VTTS, Katmal [abs.]

Kienle 1970 Gravity traverse VTTS

Klenle 1972 volc micro-quakes Augustine [abs.]

Kienle 1976 Seismic monitoring Pavlov

Kienle \&ockhart 1979 Seism \& grav survey P1lgrim HS [abs.]

Kienle Lockhart 1980 Gravity survey P1lgrim geotherm area

Kienle \&ulpan 1975 Tide caused quakes at Augustine [abs.]

Kienle Swanson 1983 Volc E Aleut arc I Quat \& Holo cntrs

Kienle \& Swanson 1983 volc E Aleut arc Quat \& Holo centers V,PG

Kienle o others 1970 selsm evidence pre 1912 tuff VTTS [abs.] Gr

Klenle \& others 1971 Microquake swarm Augustine [abs.] V,Ps

Kienle \& others 1978 Formation 2 maars Ak Penin prelim results $V$

Krause 1986 Power \& road corridor study Makushin Eg,Ps,DP

Kubota \& Berg 1967 Magma in Katma1 range

Lalla 1987 selsmo \& thermal studies Augustine (thesis)

Lalla \& Kienle 1974 Infrared thermometry Augustine [abs.] $\mathrm{V}, \mathrm{Pr}$

Lalla \& Kienle 1975 Microquakes, tremors at Pavlov [abs.]

Lalla Kienle 1978 Evolution seismicity Augustine [abs.]

Lalla \&ienle 1980 Problems volc seismo Augustine [abs.]

Lalla \& Kienle 1986 Seis therm precursors erupt Augustine V,Ps,HS 
Lockhart 1981 Gravity survey central Seward Penin. Pr Lockhart \& Rienle 1980 Seism \& grav survey Pilgrim spr KGRA Ps Lofgren 1983 Geotherm devel Pligrim springs $\mathrm{DP}, \mathrm{Gs}, \mathrm{Ps}$ Iongenkamp \& others 1974 Elec resist survey Pilgrim Springs Ps Matumoto 1971 Selsm body waves Katmal \& molten chmbr [abs.] $\operatorname{Pr}, V$ Matumoto \&olnar 1967 Shadow effect S waves Ratmal [abs.] Matumoto \& Ward 1967 Microquake study Ratmal Mauk \& Kienle 1973 Microquake Augustine earthtides McNutt 1983 Activity Paviov Shumagin gap? [abs.] MoNutt 1984 Eruption \& stress Paviov [abs.] Pr, V McNutt \& Beavan 1981 Quakes at Pavlov earth tides McNutt \& Beavan 1984 Pavlov sea level \& aselsmic slip [abs.] McNutt \& Mor1 1983 B type quakes Pavlov [abs.] Metzner 1975 Magnetotelluric invest. Augustine (thesis) Ps,V Motyka \& others 1985 Geol geoc geophys Akutan *,Gs, Fs, Ps, RM, Ff, DP Nakamura \& others 1977 Volc tectonic stress orient Aleut \& Ak $R, V$ Osterkamp \& others 1979 Conduct \& hydrol meas PIIgrim HS [abs] Ps osterkamp \& others 1980 Recon study access power Pilgrim Ps,Gs,DP Page \& others 1982 Selsm Spurr, Redoubt, \& IIlamna [abs.]

Pearson 1977 Selsmic refr-Augustine (thesis) V,Ps Pearson \& Kienle 1978 Selsmic refr study Augustine [abs.] V,Ps Pulpan \& Kienle 1978 Selsmic \& volcanic risks, Alaska V,Eg Reeder \& others 1977 Selsm Augustine volc [abs.] Reifenstuhl 1984 Geol \& geophys Goddard HS (thesis) Reifenstuhl 1986 Geol Goddard Hot Springs Gs, Ps, Fs Republ1c 1982 Unalaska Gtrml Proj $1 \mathrm{~A}$ Er,Hs,Fs,Ff,Gs,Ps,DP, RM, HA Republ1c 1983 Unalaska Gtrml Proj 1B Er,HS,Fs,Ff,Gs,Ps,DP,RM,HA Republ1c 1984 Unalaska Gtrml Proj II Er,HS, Fs, Fw, Gs, Ps, DP, RM, FA Republic 1985 Unalaska Gtrml Proj III *,Er,HS,FW,Gs, Ps,DP, RM, HA Sbar \& Matumoto 1972 Refraction VTTS Pr Self \& others 1978 Mechanisms \& deposits Ukinrek [abs.] Ps,Gs,V Shore 1985 Resist survey \& interp stone \& Packer 1972 Paleomag VTTS [abs.] Stone \& others 1971 Magnetic anomalies VTTS [abs.] Ps, RM 1972 Selsmicity geotherm areas Ak \& other (thesis) Turner \& Forbes 1980 Geol geophy stdy P1lgrim *,Gs, Ps, RM,Fs, FW, HS Turner \& Wescott 1982 Prelim Invest gthrm I Susitna Gs, Ps, GC,HS Turner \& Wescott 1986 Geotherm Invest Mt. Spurr *,R,Ps,GC,V,Gs,RM Turner \& others $1983 \mathrm{sum}$, eval gthrm exp Copper R bsn Gs,Ps,Fs, RH Updike 1986 . Eng geol, feasibil study Makushin *,Eg, Gs, Ps, Fs, DP Ward \& Matumoto 1967 Sum volc seismic activity Ratmal V,Pr Wescott 1981 He \& Hg surveys Chena HS

Wescott \& Turner 1981 Geol \& geophys Chena HS Wescott \& Turner 1982 Geotherm assit parts of AK Wescott \& Turner 1983 Geotherm expl E Copper R basin Wescott \& Turner 1983 Geotherm potent Copper $R$ basin Ge Wescott Wescott \& Witte 1982 Gravity survey I Susitna basin Turner 1985 Geotherm invest Copper $\star, G s, P s, G c$ R, Gs, Ps, GC Wescott others 1979 Resis survey Pilgrim HS [abs.]
Wescott others 1980 Resis survey Pilgrim spr area Ps, GC, Fs, Fw $\mathrm{Gs}, \mathrm{Ps}, \mathrm{GC}, \mathrm{DP}$ Wescott \& others 1981 Geophys survey summer Bay Wescott others 1982 Geophys survey Hot springs Akutan Is Ps Wescott \& others 1985 Prelim rept gthrml invest Mt Spurr Gs, Ps,Gc Wescott others 1986 Geophysical surveys Mt. Spurr Ps,R 
Wescott \& others 2986 Ice thickness Mt. Spurr summit Wilson \& Forbes 1969 Infrasonic waves \& volc erupt [abs.] Wilson Forbes 1969 Infrasonic waves Ak volc eruptions Yehle \& others 1985 Geol frm drilling in Copper R. basin

Ps

V

V

Gr

Geothermal $R$

AGS 1975 Drum thermal springs area

DP

Allen \& Zles 1923 Chem study fumaroles Katmal region Ff Anonymous 1982 Reed River Hot springs

Fs Baker \& others 1977 Geotherm springs-salmon hatchery site R,DP, Fs Barnes \& McCoy 1979 Mantle-derived CO2 in 2 phreatic expl Fs,Ff,V Barnes \& Miller 1974 Geotherm studies in Alaska [abs.] R, Fs Barnwell \& Pearson 1984 Ak resource inventory Basecu 1980 Geothermal in Alaska Beebee Kirkwood 1979 Unalaska-geothermal prospects Berry others 1980 Thermal spring list U.S. Blggar 1974 Geol geophys stdy at Chena HS (thesis) Gs, Ps,Fs, Fw Blackwell \& Steele $1986 \mathrm{NA}$ geothermal map [abs.] Bliss 1983 Ak basic data thermal springs \& welis Brook others 1979 Hydrothermal systems $<90$ deg $R, H S$ Bundtzen \& Rline 1986 Coal, peat \& geotherm in Kuskokwim Carey others 1983 Unalaska geotherm land, regs, \& environ Chalgneau Bordet 1963 Gas in glass in VTrS (Fr) Combell1ck 1986 Eng geol power plant site Makushin Conwell \& schell 1977 Energy resource map Alaska Corwin \& Fitterman 1983 Seif potentlal Makushin geotherm area Ps Dames \& Moore 1980 Geothermal drilling studies Unalaska Er Davidson 1884 First ascent Makushin

Dean \& others 1981 Remote sensing P1Igrim springs HE Denig-Chakroff 1985 Unalaska recon study Denig-Chakroff others 1985 Development pot Mak reservoir Er,DP East 1982 Geotherm investigation Manley HS (thesis) Fs, Fw, Gs, Ps East 1982 Prelim geothermal investigation Manley HS Gs,Ps,Fs Economides \& Arce 1983 Geothermal in Ak - eng geol anal EF,Er Economldes \& others 1981 Unalaska geothermal development DP Economides others 1982 Eng,geol anal geothermal sites EF,Er Economides \& others 1982 Reservoir eng analysis Pilgrim sprg Er Economides o others 1985 Eval Makushin geothermal reservoir Er Ferrians \& others 1958 Pleist volc mudflow Copper River basin $v$ Fitch 1927 Mineral waters of the U.S.

Forbes 1975 Geothermal energy \& wind power R,DP Forbes 1976 Geothermal energy for Alaska

Forbes 1979 Geol, geoph assmt of geotherm pot Pilgrim HS Gs, Ps Forbes \& Biggar 1973 Ak geothermal resource potential R, HS Forbes \& others 1975 Geophysical recon Pilgrim Springs Ps Forbes \& others 1975 UtiIization geothermal rural AK FG,DP,Ef Forbes \& others 1975 Utilization of Alaska thermal springs DP Forbes \& others 1979 Geol, geoph assmt geothrm pot Pilgrim Gs,Ps Forbes \& others 1979 Pilgrim springs hydrothermal system RM Foresman 1970 Mud volcanoes Copper River basin (thesis) Gs Gassaway \& Abramson 1977 Map \& table thermal springs cntr Ak R,Fs Godwin \& others 1971 Classif of public land for geothermal $R, D P$ Griggs 1918 VTTS mud flow $\mathrm{V}, \mathrm{H}$ 
Griggs 1921 VTTS

Griggs 1922 VTTS

Hansen \& others 1981 Mineral potential Ak Penin.

Harrison \& Hawkins 1980 Water \& heat flow Pilgrim HS

Hawkins \& Harrison 1979 Flow rate Pllgrim HS [abs.]

$\mathrm{V}, \mathrm{E}$

$\mathrm{V}, \mathrm{H}$

Hawkins \& Motyka 1985 stat \& chem anal H2O Copper River bsn Fs, Fw

H1ckel 1972 Natlonal proposal for geothermal research

Homan 1972 Energy from the earth

Hudson $1979 \mathrm{Ig}$ \& meta rocks Serpentine HS area

- Johnson 1979 Volc gas studies Ak volcanoes

* Kase 1986 Trocadero soda springs

Reith 1986 Hydrothermal alteration Novarupta [abs.]

Keith \& Foster 1979 BIg windy Creek HS

Keith others 1981 Chem \& isot data Big Windy Creek Hs

Kienle \& Lockhart 1979 Selsm \& grav survey Pligrim HS [abs.]

Kienle \& Lockhart 1980 Gravity survey Pilgrim geotherm area

Klenle others 1978 Form. 2 maars behind volc arc [abs.]

Kienle others 1978 Formation 2 maars Ak Penin prelim results

Klenle \& others 1980 Ukinrek Maars 1977 eruption

Klenle \& others 1981 Subd \& magma E Aleut arc [abs.] $R, P C$

Ring 1909 Tanana Valley

Kline 1980 Test drilling Pilgrim 1979

Kline 1981 surf geol Pilgrim vicinity

Kline \& others 1980 Surf geol \& drilling Pilgrim HS

Kodosky \& Keskinen 1986 Fumarole alt Augustine [abs.]

Kunza \& Lofgren 1983 Pilgrim HS expl, drill, \& testing

Lawton 1909 Makushin sulfur deposits

Leonard 1975 Geothermal energy

$R, D P$

Gs

$R, \mathbf{F f}$

$\mathrm{HA}, \mathrm{V}$

Fs

Fs

Ps

Ps

Iockhart \& Kienle 1980 Selsm \& grav survey Pligrim spr KGRA Ps

Lofgren 1983 Geotherm devel Pligrim springs

Iongenkamp \& others 1974 Elec resist survey P1lgrim Springs Ps

Iovering 1957 Halogen-acid alteration VTTS

Maddren 1919 Sulfur on Unalaska \& Akun Is \& stepovak Bay $\mathrm{H}, \mathrm{Gr}$

Mariner \& others 1978 Data for hydrothermal systems $>=90 \quad R, F s$

Markle 1979 Geotherm Ak site data base \& devel status R,Fs,Gr,C

- Markle 1979 Geothermal energy devel P1lgrim HS DP

Matlick \& Parmentier $1983 \mathrm{Hg}$ soll survey Makushin Gc,Fs,Ff

Meaker 1908 Tanana Valley

Menyaylov 1969 Comparison Bezymyany \&atmai (Rus)

$\mathrm{H}, \mathrm{C}$

Miller \& Barnes 1974 Geotherm devel Ak [abs.]

Miller Barnes 1976 Geotherm develop Ak summary

Miller \& Smith 1975 Ak geothermal study

Miller o others 1975 Geol \& chem hot springs $W$ cent Ak R,Fs

Horrison-Knudson Co. 1981 Geotherm potential Aleut Unalaska $R$

Motyka 1977 Katmal caldera geothermal activity V,Fs

Motyka 1978 survelllance Katmal caldera * crater lake v

Motyka 1982 Fluid geochem Makushin \& Akutan geotherm area Ff,Fs

Motyka 1982 Fluid geochemistry of Makushin Fs, Ff

Motyka $1982 \mathrm{High}$ temp hydrotherm Aleutian arc [abs.] R,Fs, Ff

Motyka 1983 Geochem \& isotope study water \& gas Makushin Fs,Ff

Motyka $1983 \mathrm{High}$ temp hydrothermal resources Aleut arc R,Fs,Ff

Motyka 1983 Thermal activity Mt Wrangell (thesis) V,HS,Ff

Motyka 1984 Chem of water \& gas Mt Wrangell [abs.] Ff 
Motyka \& Moorman 1980 Assmt thermal spring S SE Ak [abs.] R,Fs Motyka \& Moorman 1981 Recon thermal spr Aleutian arc R, Fs, Ff Motyka Hoorman 1987 Geotherm resourcers SE Ak R, Fs, Fw Motyka others 1977 Glac-volc Investigations Katmal [abs.] V Motyka \& others 1980 Assmt therm spr S SE AK R, Rs Motyka \& others 1980 Geochemistry PIIgrim thermal waters Fs, Fw Motyka others 1981 Assmt thermal spring Aleutian arc R,Fs,Ff,Gr Motyka \& others 1982 Fluid geochem Hot springs Akutan ? Fs, Ff Motyka others 1982 FIuid geochemistry Makushin area Fs, Ff Motyka \& others 1983 Fluid investigations Makushin area FE, Ff Motyka \& others 1983 Geothermal resources of Alaska R,Fs,Ff,Fw Motyka \& others 1985 Geol geoc geophys Akutan *, Gs, Fs, Ps, RM, Ff, DP Motyka \& others 1986 Makushin well chem equilib *,Fw,Fs,Ff, HA, RM Muffier 1973 Geothermal resources

Muffler 1979 Assmt geothermal resources U. S. Nathenson \& others 1983 Reglonal heat flow Nava 1975 Note on hot springs SE AK Nava \& Morrison 1974 Note on hot springs interior AK Nehring \& others 1979 sulfate geotherm western U. S. $R, F \boldsymbol{B}, \mathrm{HS}$ $R$, HS Nichols \& Reeder 1983 Ak geothermal \& hydrotherm development R,DP Nichols \& Yehle 1961 Anal gas \& water Copper River basin Fs Nichols \& Yehle 1961 Mud volc Copper River basin Fs Nye \& Swanson 1986 Chem strat magma plumb Kakushin [abs] V,Gs, PG Nye \& others $1984 \mathrm{Geol}$ map Makushin geothermal area Nye \& others 1986 Petro geochem Quat volc Makushin Ogle 1976 Ak. hot spring site for small binary plant Okada \& Okada 1974 Hot springs village Port Moller Okada \& Okada 1980 Hot springs site Port Moller Okada others 1976 Hot springs village Port Moller okada \& others 1979 Hot springs village port Moller R,Fs R,Fs R, FE Osta Pas access power P1lgrim Ps,Gs,DP Parmentier \& others 1983 Geol \& hydrotherm alter Makushin Gs, HA Peale 1886 Mineral springs of US Poreda \& others 1981 He lsot vars Ak-Aleut arc [abs.] Queen 1984 Ifth $\mathrm{log}$ \& hydrotherm alt of core from Makushin IIA Queen 2987 Alt, H2O-rock equil, Makushin (thes1s) HA, FW, Gs, Gc, HS Queen \& Motyka 1984 Changes in Makushin geoth system [abs.] HA Ramdohr 1962 Magnetite from fumaroles VTTS (Ger) HA Reed \& others 1983 Data low temp geothermal systems US HS,R,Fs Reeder 1981 Initial assmt hydrotherm summer Bay Unalaska Er,Gs Reeder 1981 V-D hydrotherm maifest Unalaska [abs.] Gs, Ff Reeder 1982 Hydrotherm potential Aleut arc-Makushin [abs] DP Reeder 1982 Hydrothermal resources Makushin region

Reeder 1982 Hydrothermal resources N Unalaska Is

Reeder 1984 Fault \& dike orientation Makushin [abs.]

Reeder 1986 Ground stability, spring water Broad Bay

Reeder others 1980 Ak. geothermal program

Reeder \& others 1980 Geothermal Implementation plan

Reeder others 1982 Econ eng geoth develop Makushin

Reeder others 1985 Geol geotherm resource Makushin Reifenstuhl 1984 Geol geophys Goddard HS (thes 1s)

Reitsema 1979 Gases of mud volc Copper River basin FE, Ff DP Gr

$\mathrm{Eg}, \mathrm{Fs}, \mathrm{Gs}$ DP DP $E F, E g, D P$ R, Gs Republic 1983 Unalaska Gtrml Proj IB Er,HS,Fs,Ff,Gs,Ps,DP,RM, HA 
Republic 1984 Unalaska Gtrml Proj II Er,HS,FS,FW, GS,Ps,DF, RM, HA Republic 1985 Unalaska Gtrml Proj III *,Er,HS, Fw, Gs, Ps, DP, RM, HA Romick 1986 Ig pet and geochem N. Akutan Rosenbruch Bottge 1975 Econ potent 3 sites Ak Rosenthal 1908 Hot springs of southeast Alaska $H, R$ Sainsbury \& others 1970 Geol min dep geochem \& rad serpentine Gr Sammel 1979 Low temp. geothermal in U.S.

Sayre \& Hagelbarger 1918 Temps in VTrS

Self \& others 1980 Ukinrek Maars II deposits \& formation

Shipley 1919 VTTS

Shipley 1920 Chem obs VTTS

Shore 1985 Resist survey \& interp

Sloan 1976 Chem anal Bailey Bay HS

sloan 1976 Chem anal Bell Is HS

Sloan 1976 Chem anal Chief Shakes HS

Smith \& Shaw 1979 Igneous related geothermal systems

Smith \& others 1978 Data \& therm energy est young ig sys us

Sosman 1919 Temp in fumaroles VTTS

Spencer \& others 1982 Anal geothrm res devel Unalaska

stefano 1974 Low temp use Pilgrim HS

Stefano 1975 Pilgrim HS could heat Nome

Stern \& Stirling 1982 Pilgrim Hot Springs Road

Swanson others 1980 Bedrock geol Pilgrim springs area

Taber 1972 Selsmicity geotherm areas Ak \& other (thesis)

Thompson \& Keith $1984 \mathrm{cl} \& \mathrm{~F}$ in waters VTTS [abs.] Fs

H, HS

$\mathrm{v}$

H

$\mathrm{HA}, \mathrm{FF}$

PS, RM

FS

Fs

Fs

$R$, ES

R, ES

H, HS

$\mathbf{E F}, \mathrm{DP}$

DP

DP

$C, R$

Gs

$\mathrm{R}, \mathrm{Pr}$

Turner \& Forbes 1980 Geol geophy stdy Pilgrim *,Gs,Ps, RM, Fs, Fw, HS

Turner \& Nye 1986 Geochronology Mt. Spurr

Turner \& Swanson 1981 Continent rifting new model seward Pen Gr

Turner \& Wescott 1982 Prelim invest gthrm I Susitna Gs,Ps,GC,HS

Turner \& Wescott 1986 Geotherm invest Mt. Spurr *,R, Ps,GC,V, Gs, RM

Turner \& others 1979 Geol \& tect setting Pilgrim spr [abs.] Gs

Turner \& others 1980 Geothermal resources Alaska R,Fs

Turner others 1980 sum geol geophys invest Pilgrim spr RM

Turner \& others 1981 Continent rifting new model Seward Pen Gr

Turner \& others 1983 sum, eval gthrm exp Copper R bsn Gs,Ps, Fs, RM

Turner \& others $1986 \mathrm{kt}$. Spurr geothermal project R,GS,V

Turner \& others $1986 \mathrm{Hg}$ and He surveys Mt. Spurr Gc, R

Updike $1986 \mathrm{Eng}$ geol, feasibil study Makushin *,Eg,Gs,Ps,Fs, DP

Viglino \& others 1985 Isot evid magma comp in fum cond Augst V, Ff

Wanek 1973 Geotherm areas by merialian \& acreage

Waring 1917 Mineral springs Ak

Waring 1965 Thermal springs US \& world - a summary

Wescott 1981 He \& Hg cent Seward Penin

Fs, R Fs

Wescott $1981 \mathrm{He} \& \mathrm{Hg}$ surveys Chena HS

Wescott \& Turner 1981 Geol \& geophys Chena HS

Wescott \& Turner 1981 Geotherm recon C Seward Pen Gs,Ps,GC,HS, RM

Wescott \& Turner 1982 Geotherm assmt parts of Ak R;Gs,Ps,GC

Wescott \& Turner 1983 Geotherm expl E Copper R basin Ps,Gc,Fs, FW

Wescott Turner 1983 Geotherm potent Copper R basin Gs,Ps,GC,DP

Wescott \& Turner 1985 Geotherm invest Copper *, Gs, Ps, GC, DP, Fs, Fw

Wescott \& Witte 1982 Gravity survey I Susitna basin Ps

Wescott \& others 1979 Resis survey Pilgrim HS [abs.] $\therefore \quad$ Ps

Wescott \& others 1980 Resis survey Pilgrim spr area Ps

Wescott \& others 1982 Geophys survey Hot Springs Akutan Is Ps 
Wescott others $1982 \mathrm{He}$ \&g survey parts Unalaska GC Wescott others 1985 Prelim rept gthrml invest Mt spurr Gs,Ps,Gc Wescott \& others 1986 Geophysical surveys Mt. Spurr Ps,R Wescott others 1986 Ice thickness Mt. Spurz sumit Ps White \& Willams 1975 Assmt geothermal resources US R,Fs, HS Wiltse 1986 Radon hazard assessment Circle HS Woodward-Clyde 1983 Geothermal development Pilgrim spr DP zies 1921 Hot springs in VTTS

Zles 1924 Fumarolic incrustations Katmal [abs.]

zles 1924 Fumarolic incrustations VTTS

zles 1929 VTTS I-fumarolic incrustations, II-acid gases

Heat flow studies and estimates of thermal energy HS

Bingham 1967 Ice \& heat studies Mt. Wrangell (thesis) V,HS

Bingham \& Benson $1967 \mathrm{Mt}$. Wrangell ice \& heat studies V,HS Blngham \& Benson 1968 Ash temp variations Mt Wrangell V, BS Blackwell steele $1986 \mathrm{NA}$ geothermal map [abs.] $R$,HS Blanchard \& Tailleur 1982 Prelim geothermal isograd map NPRA HS Forbes \& Biggar 1973 Ak geothermal resource potential R, HS Forbes \& others 1975 Fission track age \& geotherm grad [abs.] HS Forbes \& others 1977 Fission track age \& geothermal gradient HS

- Gosink \& Osterkamp 1980 Prelim invest hot water PIIgrin RIver HS Harrison \& Hawkins 1980 water \&eat flow PIIgrim HS HS,DP Hawkins \& Harrison 1979 Flow rate Pilgrim HS [abs.] HS,DP Isselhardt \& others 1983 Geotherm resource model Makushin RM,HS Isselhardt \& others 1983 Temp grads Makushin geothermal area HS Ke1th 1984 Prelim obs fumaroles VTTS

Keith 1985 Hydrotherm alt Novarupta dome VTTS [abs.] HA Lachenbruch \& others 1984 Geotherm Prudhoe Bay Lalla 1987 Seismo \& thermal studies Augustine (thesis) V,Ps, HS Lalla Kienle 1974 Infrared thermometry Augustine [abs.] V,HS Lalla \& Kienle 1976 Thermal studies Augustine [abs.] Lalla \& Kienle 1986 Sels therm precursors erupt Augustine V,Ps, HS Lawver \& others 1979 Regional heat flow Ak Motyka 1983 Thermal activity Mt Wrangell (thesis) V,HS,Ff Motyka \& Benson 1982 Flucts in heat flow Mt Wrangell [abs.] V, HS Motyka others 1978 Increased heat Mt Wrange1] [abs.] HS Motyka others $1980 \mathrm{Mt}$ Wrangell glac meas heat flow [abs.] V, HS Muffler 1979 Assmt geothermal resources $U$. $S$. R,Fs, HS Nathenson others 1983 Reglonal heat flow R, HS Queen 1987 Alt, H20-rock equil, Makushin (thes 1s) HA, FW, Gs, Gc, HS Reed \& others 1983 Data low temp geothermal systems US HS,R,Fs Republ1c 1982 Unalaska Gtrml Proj IA Er,Hs,Fs,Ff, Gs, Ps, DP, RM, HA Republic 1983 Unalaska Gtrml Proj 1B Er,HS,Fs,Ff,Gs, Ps, DP, RM, HA Republ1c 1984 Unalaska Gtrml Proj II Er,HS,Fs, Fw, Gs, Ps, DP, RM, HA Republ1c 1985 Unalaska Gtrml Proj III *,Er,HS,Fw,Gs, Ps,DP, RM, HA Sayre \& Hagelbarger 1918 Temps in VTTS H,HS Smith \& Shaw 1979 Igneous related geothermal systems R,HS Smith \& others 1978 Data \& therm energy est young ig sys US R, HS Sosman 1919 Temp in fumaroles VTTS H,HS Turner \& Forbes 1980 Geol geophy stdy Pilgrim *,Gs, Ps, RM, Fs, Fw, HS Turner \& Wescott 1982 Prelim invest gthrm I susitna Gs,Ps,Gc,HS Wendler 1967 Heat flow Mt. Wrangell

$\mathrm{V}$, HS 
White \& Willams 1975 Assmt geothermal resources US White \& Williams 1975 Assmt geothermal resources US

R,FE, HS

R, FE, HS

\section{Historic reports H}

Beaglehole 1967 Journals of Captain James Cook H

Becker 1898 Recon of goldfields southern Alaska H

Brown 1899 Shishaldin

Clark 1912 Katmal eruption

Collier 1902 Recon NW Seward Penin

Dally 1912 Eruption of Ratmal

Dall 1870 Alaska and its resources

Dall 1870 Bogosloff volcano

Dall 1884 New volcano island

Dall 1889 Notes on Bogoslof island

Davidson 1884 First ascent Makushin

Davidson 1884 New Bogoslof volcano

Davidson 1884 New volcano in Alaska

Davidson 1884 Notes volc eruption Augustine

Davidson 1893 Eruption of Veniaminof

Davydov 1809 Voyages to Russian America 1802-1807

Dilier 1884 Volcantc sand Unalaska

Diller 1893 our youngest volcano

Dunn 1909 Conquering Ht wrangell

Escher 1922 Lahar VTTS

Fenner 1920 . Geol Katmal 1912 eruption [abs.]

Fenner 1920 Katmal great eruption of 1912

Fenner 1923 Tuff deposit VITS

Fenner 1923 Tuff deposit VTTS

Fenner 1930 . Mt Katmai \& Mt Mageik

Fenner 1937 Tuffs of Katmal \& Yellowstone

Finch 1935 Akutan volcano

Fitch 1927 Mineral waters of the U.S.

Fry 1912 Mineral content volcanic ashes

Grewingk 1850 Historic geology NW North America (Ger)

Griggs 1917 VTTS

Griggs 1918 Eruption of Katmai

Griggs 1918 Eruption of Ratmai

Griggs 1918 VTTS

Griggs 1918 VTTS mud flow

Griggs 1919 Ratmal \& VTTS

Griggs 1921 VTTS

Griggs 1921 VTTS

Griggs 1922 VTTS

Griggs 1923 VTTS

Hralicka 1945 Aleutian Is inhabitants

Hubbard 1931 Geol Aniakchak \& Veniaminof [abs.]

Hubbard

1931 World inside a mountain

Hubbard 1935 Cradle of storms

Jackson 1880 Alaska \& its missions

Jaggar 1908 Evolution Bogoslof Volcano

Jaggar 1908: Evolution of Bogoslof [abs.]

Jaggar 1908 Technical expedition to Aleutians

Jaggar 1927 Eruption of Mageik 
King 1909 Tanana Valley

Knappen 1933 Anlakchak \& Veniaminof volcanoes [abs.]

Martin 1913 Eruption Katmal

Meaker 1908 Tanana Valley

Merriam 1901 Birth of Bogoslof

Merrill 1885 Hornblende andesites from Bogosloff

Miller others 1966 Prelim plutonic belt W cent Ak

Okimura 1930 Eruption Katmai

Palache 1904 Geol Chlchagof Cove, Stepovak Bay

Peale 1886 Mineral springs of US

Perrey 1866 Quakes \& volcanism Aleutlans \& Ak Penin (Fr)

Petrov 1884 Alaska population \& resources

Prosser 1912 Volcanic road-bullding

Reck 1930 Review VTTS (Ger)

Robinson 1948 Exploring Aleutian volc

Rosenthal 1908 Hot springs of southeast Alaska

Sayre \& Hagelbarger 1918 Temps in VTTS

Schrader \& Spencer 1901 Geol a min res Copper River dist

Shelikhov 1790 voyage to America 1783-1786

Shipley 1919 VTTS

Sosman 1919 Temp in fumaroles VTTS

Spurr 1900 Recon in SW Ak 1898

stoney 1884 volcano in Bering sea

Stoney 1900 Naval expl Alaska

Tams 1924 Katmal (Ger)

Veniaminov 1840 Notes on Islands Unalaska district

Vonlangsdorff 1814 Voyages \& travels 1803-1807

Westdahl 1900 Mountains on Unimak

Whymper 1868 Journey Norton Sound to Fort Yukon

Wright 1906 Nonmetallic deposits SE Ak.

$$
\begin{aligned}
& \text { Gr } \\
& V, H \\
& \mathrm{H}, \mathrm{C} \\
& \mathrm{H}, \mathrm{V} \\
& H, G s, \text { PG } \\
& \text { Gr } \\
& \mathrm{V}, \mathrm{H} \\
& \text { Gr, H } \\
& \mathbf{H}, \mathbf{R} \\
& \text { H } \\
& \mathrm{H}, \mathrm{C} \\
& \mathrm{H}, \mathrm{V} \\
& \text { H, V } \\
& \mathrm{V}, \mathrm{H} \\
& \mathbf{H}, \mathbf{R} \\
& \text { H, HS } \\
& \mathrm{H}, \mathrm{Gr} \\
& \mathrm{H}, \mathrm{C} \\
& \text { H } \\
& \mathrm{H}, \mathrm{HS} \\
& \mathbf{H}, \mathbf{G r} \\
& \text { H, V } \\
& \mathrm{H}, \mathrm{Gr} \\
& \boldsymbol{V}, \mathbf{H} \\
& \text { H } \\
& \text { H } \\
& \text { H }
\end{aligned}
$$

$H A$

Keith 1986 Hydrothermal alteration Novarupta [abs.]

Kodosky Keskinen 1986 Fumarole alt Augustine [abs.]

Iovering 1955 Alteration near halogen-sulfur fumarole

Lovering 1957 Halogen-acid alteration VTTS

Motyka \& others 1986 Makushin well chem equilib *,FW,Fs,Ff, HA, RM Parmentier \& others 1983 Geol \& hyarotherm alter Makushin Gs, HA Queen 1984 Iith Iog \& hydrotherm alt of core from Makushin HA Queen 1987 Alt, H2O-rock equil, Makushin (thesis) HA, Fw, Gs,GC,HS Queen \& Motyka 1984 Changes in Makushin geoth system [abs.] HA Ramdohr 1962 Magnetite from fumaroles VTSS (Ger) HA Republic 1982 Unalaska Gtrml Proj 1A -Er,Hs, FE, Ff, Gs, Ps, DP, RM, HA Republ1c 1983 Unalaska Gtrml Proj IB Er,HS,Fs,Ff,Gs, Ps,DP, RM, HA Republ1c 1984 Unalaska Gtrml Proj II Er,HS, Fs, FW, Gs, Ps,DP, RM, HA Republic 1985 Unalaska Gtrml Proj III *,Er, HS, Fw, Gs, Ps, DP, RM, HA Shipley 1920 Chem obs VTTS

Shipley 1920 Katmal gas \& encrustations

Z1es 1924 Fumarol1c incrustations Katmal [abs.] $\mathrm{HA}, \mathrm{Ff}$ Zies 1924 Fumarolic incrustations VTTS $\mathrm{HA}, \mathrm{FE}, \mathrm{V}$ zies 
Maps

Andreasen \& others 1958 Aeromag Copper River basin $\mathrm{Pr}$

Bader 1984 Geol map eastern N. slope Ak.

Bader \& Bird 1986 Geol map NE Alaska

*Beikman 1974 Prelim geol map SE Quad of Alaska

Beikman 1974 Prelim geol map sw Quad Alaska

Belkman 1975 Prelim geol map SE Alaska

Belkman 1980 Geologic map of Alaska

Belkman \& Lathram 1975 Prelim geol map N Ak

Berg \& others 1978 Geol map Ketchikan \& Prince Rupert Q Ak. Gr

Berry \& others 1980 Thermal spring list U.S.

Gr

Gr

Gr

G

$\mathbf{G r}$

Gr

Gr

$\mathbf{R}$

Biggar 1974 Geol geophys stdy at Chena HS (thesis) Gs,Ps,Fs,Fw Blackwell \& steele $1986 \mathrm{NA}$ geothermal map [abs.] $R$, HS Blodgett \& Gilbert 1983 Cheeneetnuk limestone MC Grath Gr Brew \& Ford 1985 Geol map Juneau, Taku, Atlin, skag quad Gr Brew \& others 1984 Geologic map Peterbrg, Sumdum, P. Alex Gr Brosge \& Patton 1982 Bedrock geol maps Dalton Hwy Gr Brosge \& Pessel 1977 Prelim recon geol map Survey Pass Q Gr Burk 1965 Geol Ak Penin-island arc \& continental margin Gr Carrick \& Maurer 1986 Hydrology - Makushin Carter \& Galloway 1978 Geol map proposed gas Iine Cass 1959 Recon geol map Melozitna Q Ak. Chapman \& others 1975 Prelim geol map Tanana NE Kantishan Q Gr Chapman \& others 1982 Recon geol map Tanana Q Collazzi \& Ireland 1986 Hydrology lower Kuskokwim basin Combelilck 1986 Eng geol power plant site Makushin Conwell \& Schell 1977 Energy resource map Alaska Decker 1980 Geol Cret. subduct complx Chichagof Is (thesis) Decker 1980 Geol map $w$ Chichagof Island

Decker \& others 1984 Geol data Russian Mission A-3 Quad Detterman 1973 Geol map Illamna B-2 Quad Augustine Island Detterman \& Reed 1964 Prelim geol map Iliamna $Q$ Detterman \& Reed 1968 Geol Iliamna $Q$

Detterman \& Reed 1980 strat, struct, \& econ geol Iliamna Q

Detterman \& others 1976 Geol map by faults in Kenai \& Tyonek $Q$ Detterman \& others 1979 Geol map Chignik \& Sutwik Is Q Detterman \& others 1981 Geol map Chignik \& sutwik Is $Q$ Detterman \& others 1981 Quat geol map Chignik \& Sutwik Is Q petterman \& others 1983 Geol map Ugashik-Bristol Bay-Karluk $Q$ Eetterman \& others 1985 Geol map Ugashik \& W Karluk Q Detterman \& others 1986 Quat map Ugashik-Bristol Bay-Karluk Q Dilion \& others 1983 Geol map Melozitna A-4 Quad

Eberlein \& others 1977 Prelim geol map central Alaska Eberlein \& others 1983 Geol map Craig Q

Foster 1970 Recon geol map Tanacross Quad

Foster \& others 1983 Geologic map Circle $Q$

Foster \& others 1983 Prelim geol map Circle quad Gassaway \& Abramson $1977 \mathrm{Map}$ \& table thermal springs cntr Ak R, FE Gilbert 1981 Geologic map Cheeneetnuk River area Gilbert \& Solie 1983 Prelim geol map Mc Grath A-3 Quad Gr Hoare Coonrad 1959 Geol map Russian Mission Quad Holmes 1986 Archaelogical evaluation Makushin Hudson 1977. Geol map Seward Penin Gr c 
SUBJECT

ADDITIONAL TOPICS

Imm 1986 Geol \& strat Mt Michelson quads

Jones \& others 1984 Terrane map Alaska

Krause 1986 Power road corridor study Makushin

Lecompte 1981 Prel1m map Landsat Ugashik \& Karluk Q

Lecompte \& steele 1981 Map Landsat Chignik \& Sutwik Is Q

Ioney \& others 1963 Recon geol map Chichagof \& NW Baranof Is Gr

Ioney others 1964 Recon geol map Baranof \& Kruzof Is

Long 1986 Glacial hazard Makushin

Mackevett 1976 Geol map McCarthy $Q$

Mackevett 1978 Geol map McCarthy Q

March 1986 Avalanche hazards- Makushin

Melgs 1986 structural evol Sadlerochlt Mts.

Menzle \& others 1983 Mineral assmt Circle Quad

Miller 1973 Distribution \& chem analysis thermal springs Ak $R$

Miller \& others 1972 Prelim geol map Solomon \& SE Bendeleben $Q$ Gr

Monger \& Berg 1985 Terrane map SE Ak. \&. Can.

Gr

Motyka others 1983 Geothermal resources of Alaska R,Fs,Ff,Fw Motyka o others 1985 Geol geoc geophys Akutan *, Gs, Fs, Ps, RM, Ff, DP Nichols \& Yehle 1969 Eng geol map SE Copper River basin

Nye 1986 Volcanic hazards, Makushin

Nye \& others 1984 Geol map Makushin geothermal area

Nye others 1986 Petro geochem Quat volc Makushin

Patton \&iller 1966 Regional geol map Hughes $Q$

Gs

Patton \& others 1968 Reg geol map Shungnak \& Ambler River Q Gr

Patton \& others 1978 Geol map Melozitna $Q$

Pavia 1986 structure \& strat okpllak batholith area

$\mathbf{V}, \mathbf{E g}$

Pewe 1975 Quaternary geology of Ak

Reed \& Ianphere 1972 Geol map Ak-Aleut batholith $\mathrm{K} / \mathrm{Ar}$ ages

Reifenstuhl 1986 Geol Goddard Hot Springs

Gs, Ps, Fs

Republ1c 1982 Unalaska Gtrml Proj $1 A$ Er,Hs, Fs, Ff, Gs, Ps, DP, RM, HA

Republic 1983 Unalaska Gtrml Proj 1B Er,HS,Fs,Ff,Gs, Ps,DP,RY, HA

Richter 1975 Geol map Nabesna Q

Rlchter 1976 Geol map Nabesna Q

Richter \& others 1979 Geol map Gulkana A-2 Q

Gr

Robinson \& Stevens 1983 Geol map Seward Penin

$\mathbf{G r}$

Robinson \& stevens 2984 Geol map seward Penin

Robinson \& others 1984 Geologic map sleetmute B-5 Q

Robinson \& others 1986 Geol map Mt. Michelson C-4 Quad

Gr

Gr

Gr

Rogers 1986 Geology Shublik Mts

Turner \& NYe 1986 Geochronology Mt. Spurr

Turner \& Wescott 1986 Geotherm invest Mt. Spurr *,R, Ps, Gc, V, Gs, RM

Turner \& others 1980 Geothermal resources Alaska

Turner o others $1986 \mathrm{Mt}$. Spurr geothermal project

Turner others $1986 \mathrm{Hg}$ and He surveys Mt. Spurr

Updike 1986 Construction materials Makushin

Updike 1986 Eng geol, feasib11 study Makushin *,Eg, Gs, Ps, Fs, DP

Wescott \& Turner 1983 Geotherm expl E Copper R basin Ps, GC,Fs, Fw

Wescott Turner 1985 Geotherm invest copper *,Gs, Ps, Gc,DP, Fs, Fw

Wescott Witte 1982 Gravity survey I Susitna basin

Wescott \& others 1986 Geophyslcal surveys Mt. Spurr

Williams 1985 Eng geol map Copper River basin

Ps

Will lams Johnson 1980 Map Tert Quat deposits Valdez $Q$

Ps, R

Wilson 1977 plutonic rocks SW Ak data compliation

Wilson \& Shew 1981 Prelim $\mathrm{K}-\mathrm{Ar}$ studies circle $Q$

Eg

Gr

Gr

Gr 
Wilson \& Turner 1975 Rad age map Aleutians

Gr

wilson \& Turner 1975 Rad age map N Ak

Wilson \& Turner 1975 Rad age map SC Ak

Wilson \& Turner 1975 Rad age map SE Ak

Wilson \& Turner 1975 Rad age map SW Ak

Winkler \& others 1981 Follo Valdez $Q$

Yehle Nichols 1980 Recon map Chetaslina debris flow Copper $R$

Petrology and geochemistry of rocks PG

Ach : DeIong 1980 Magma evo L. Sitkin \& Semisopochnol [abs.] PG

Baker \& Eggler 1983 Atka high alumina basalt

Brophy \& Marsh 1984 Petro \& geochem Cold Bay volc [abs.]

Byers 1961 Petro 3 volc suites Umnak \& Bogoslof Islands

Chaigneau Bordet 1963 Gas in glass in VTTS (Fr)

Coats 1952 Magmatic different Adak \& Kanaga Islands

coats 1962 Magma type \& crustal structure Aleutian arc

Conrad \& Kay 1984 Inclusions Adak Is-nature of primary magma

Daley 1986 Petro, geochem \& evol magmas Augustine (thesis)

Daley \& Swanson 1985 Low press fractionation Augustine [abs.]

Fenner 1926 Katmal magmatic province

Fenner 1950 Chemical kinetics Katmai eruption

Forbes Rienle 1971 Petro pre 1912 pyroclast VTTS [abs] PG,Gs,V

Fournelle Marsh 1986 Shlshaldin lavas [abs.]

Furst 1968 Recon petrol Ht Wrangell caldera (thesis)

PG

Harmon \& others 1984 Augustine chem \& isot character [abs.]

Herreld 1966 Geol \& geochem Inmachuk River

Hildreth 1980 Novarupta 1912 Petro of ejecta [abs.]

Hildreth 19811912 eruption VTTS [abs.]

Hildreth 1983 zoned eruption 1912 VTTS

PG

$P, V$

PG

PG

PG

PG

PG

PG

PG

Hildreth \& Grunder 1980 VITS comp lotope of ejecta

Hila \& G isotope of ejecta [abs.] PG

Hudson 1977 zoned granite stock seward Penin

Hudson 1977 Zoned granite stock Seward Penin. (thesis)

Johnson 1978 Magma mixing Augustine volcano (thesis)

Johnson 1978 Magma mixing Augustine volcano [abs.]

Kay \& Kay 1982 Aleut volc rock, primitive magmas [abs.]

Kay \& others 1982 Tectonic control of magmatism Aleut arc

Kienle \& Swanson 1983 Volc E Aleut arc I Quat \& Holo cntrs Kienle \& Swanson 1983 Volc E Aleut arc Quat \& Holo centers Kienle others 1981 subd \& magma $E$ Aleut arc [abs.]

Kienle \& others 1983 Magmatism subduction $E$ Aleutian arc

Kosco

1981 Andesitic volcanism at Katma1

Rosco

1981 Edgecumbe volc \& Katmal

(thesis)

Marsh 1974 Aleutian arc magmatism (thesis)

Marsh 1982 Aleutians - orogenic andesites

Merrill 1885 Hornblende andesites from Bogosloff

Miller 1970 Petro plutonic rocks $W$ central Ak

Miller 1971 Petro plutonic rocks $W$ cent Ak (thes is)

$P G, V$

PG

PG

PG

PG

PG

Milier

$1972 \mathrm{~K}$ rich intrusive rocks $\mathrm{W}$ Ak

PG

$P G$

PG

PG

PG

PG

PG

Miller 19842 stage volcanism Ugashik-Peulik [abs.]

$V, P G$

$V, P G$

R,PG

$V, P G$

PG

PG

$V, P G$

Gr,PG

H, Gs, PG

Motyka \& Queen 1984 Makushin fluids samps \& well log Fs,Ff,Fw,PG

Myers 1978 Petro \& petrogenesis Edgecumbe volc [abs.] PG

Myers 1979 Geol, petro Edgecumbe: trnsfrm fault volc (thesis) PG 
Myers \& Marsh 1981 Geol \& petrogen Edgecumbe volcanics $\quad$ PG Myers \& others 1984 Assim crust by basalt magma Edgecumbe PG Myers \& others 1986 Isot var Adak \& Atka volc plumb V,PG, Gr Neal Swanson 1983 Petro geochem Westdahl Pogromni [abs.] PG Nye 1983 Petro \& geochem okmok \& Wrangell volcs (thesis) PG,V Nye Reid 1986 Geochem pri lava Okmok Volc: arc magmagenesis PG Nye Swanson 1986 Chem strat magma plumb Makushin [abs] V,Gs,PG Nye Swanson 1987 Makushin magma chamber PG,Gs,V Nye \& Turner 1986 Geology geochemistry Spurr [abs.] Gs, PG,V Nye others 2983 Parental magmas okmok: arc magmagen [abs.] PG Nye others 1986 Petro geochem Quat volc Makushin *,V,Gs, PG Perfit \& others 1980 Model for fract in Aleut calc-alk suite PG Ramdohr 1962 Magnetite from fumaroles VTTS (Ger) HA Ray 1967 Geochem \& petro Mt Trident andesites (thesis) PG Ray \& others 1966 Petro \& geochem Mt Trident andesites [abs.] PG Reed Lanphere 1972 Geol map Ak-Aleut batholith K/Ar ages Gr Reed \& Ianphere 1973 Ak-Aleut batholith, geochron \& chem Gr Reifenstuhl 1984 Crawfish Inlet Pluton Baranof Is [abs.] Gs,PG Robinson \& Decker 1986 Ages a analysis from SW Alaska Gr,PG Robinson \& others 1986 Rocks from Sleetmute, Russian Mission Q PG Romick 1982 Ig petro \& geochem N. Akutan Is (thesis) Romick 1983 Ig petro geochem N. Akutan Is [abs.] Romick 1986 Ig pet and geochem N. Akutan

Romlck \& Swanson 1983 Petro fract lava Akutan Is [abs.] Rubenstone others 1985 Isot \& trace elem Katma1 [abs.] Swanson $2983 \mathrm{Min}$ \& fract Makushin volc [abs.]

Swanson \& Blum 1984 Evol of volc centers Aleutian arc [abs]

Swanson \& others 1981 Geol petro kaguyak Crater [abs.]

Swanson \& others 1983 Petro Makushin volc [abs.]

Swanson \& others 1986 Magmatic evolution Augustine [abs.] T111 1984 Redoubt-strat volc hazards [abs.] Woodruff Anderson 1980 Arrested magma mixing Pavlov Yount 1984 Redoubt mineralogy \& chem [abs.]

Campbel1 \& Economides 1984 summary Well no. 1 Makushin volc Er Dames \& Moore 1980 Geothermal drilling studies Unalaska Er Denig-Chakroff \& others 1985 Development pot Mak reservoir Er,DP Economides \& Arce 1983 Geothermal in Ak - eng \& geol anal EF,Er Economides \& others 1982 Eng,geol anal geothermal sites EF,Er Economides \& others 1982 Reservoir eng analysis Pilgrim Sprg Er Kline 1980 Test driling Pilgrim 1979 Er Kline others 1980 surf geol \& drilling Pllgrim HS Gs,Er Kunza \& Lofgren 1983 Pilgrim HS expl, drill, \& testing Er Reeder 1981 Initial assmt hydrotherm Summer Bay Unalaska Er,Gs Republic 1982 Unalaska Gtrmi Proj IA Er,Hs,Fs,Ff,Gs,Ps,DP, RM, HA Republic 1983 Unalaska Gtrml Proj IB Er,HS,Fs,Ff,Gs,PS,DP, RM, HA Republic 1984 Unalaska Gtrml Proj II Er,HS, Fs, Fw, Gs, Ps, DP, RM, HA Republic 1985 Unalaska Gtrml Proj III *,Er, HS,Fw, Gs, Ps, DP, RM, HA 
Resource model RM

Forbes \& others 1979 Pilgrim springs hydrothermal system

Isselhardt \& others 1983 Geotherm resource model Makushin RM,HS Motyka \& others 1985 Geol geoc geophys Akutan *,Gs,Fs, Ps, RM, Ff, DP Motyka \& others 1986 Makushin well chem equilib *,Fw, Fs, Ff, HA, RM Republic 1982 Unalaska Gtrml Proj IA Er,Hs, Fs,Ff, Gs, Ps, DP, RM, HA Republic 1983 Unalaska Gtrml Proj 1B Er,HS,FG,Ff,Gs, Ps,DP, RM, HA Republic 1984 Unalaska Gtrml Prof II Er,HS,Fs, Fw, Gs, Ps, DP, RM, HA Republic 1985 Unalaska Gtrml Proj III *,Er,HS,Fw,Gs, Ps,DP, RM, HA Shore 1985 Resist survey \& Interp

Ps, RM

Turner \& Forbes 1980 Geol geophy stdy Pilgrim *,Gs, Ps, RM, Fs, Fw, HS Turner \& Wescott 1986 Geotherm invest Mt. Spurr *, R, Ps, GC, V, Gs, RM Turner \& others 1980 sum geol geophys invest Pilgrim spr RM Turner \& others 1983 sum, eval gthrm exp Copper R bsn Gs, Ps,Fs, RM Wescott \& Turner 1981 Geotherm recon C Seward Pen Gs, Ps,Gc,HS, RM

Spring and stream chemistry Fs

Anonymous 1982 Reed River Hot Springs : Fs Baker \& others 1977 Geotherm springs-salmon hatchery site R,DP,Fs Barnes \& McCoy 1979 Mantle-derived CO2 in 2 phreatic expl Fs,Ff,V Barnes \& Miller 1974 Geotherm studies in Alaska [abs.] $R, F s$ Biggar 1974 Geol \& geophys stdy at Chena Hs (thes1s) Gs, Ps,Fs, Fw Bliss $1983 \mathrm{Ak}$ basic data thermal springs \& wells $\mathrm{R}, \mathrm{Fs}$, FW Brook \& others 1979 Hydrothermal systems <90 deg R, Fs Carrick \& Maurer 1986 Hydrology - Makushin

East 1982 Geotherm investigation Manley HS (thesis) Fs,Fw,Gs,Ps East 1982 Prelim geothermal investigation Manley HS Gs,Ps,Fs Forbes \& others 1975 Utilization geothermal rural Ak Fs,DP,Ef Gassaway \& Abramson 1977 Map \& table thermal springs cntr Ak R, Fs Grantz \& others 1962 Saline springs Copper River basin Fs Hawkins \& Motyka 1985 stat \& chem anal H2O Copper River bsn Fs,Fw Keith \& Foster 1979 Big Windy Creek HS Fs Keith \& others 1981 Chem \& isot data Big Windy Creek HS Fs Mariner \& others 1978 Data for hydrothermal systems $>=90$ R, Fs Markle 1979 Geotherm Ak site data base \& devel status R,Fs,Gr,C Matlick \& Parmentier $1983 \mathrm{Hg}$ soll survey Makushin Gc,Fs,Ff Miller 1973 Distribution \& chem analysis thermal springs Ak R,Fs Miller \& others 1975 Geol \& chem hot springs W cent Ak R,Fs Motyka 1977 Katmal caldera geothermal activity

Motyka 1982 Fluid geochem Makushin \& Akutan geotherm area Ff,Fs Motyka 1982 Fluid geochemistry of Makushin

Motyka $1982 \mathrm{High}$ temp hydrotherm Aleutian arc [abs.] R,Fs,Ff Motyka 1983 Geochem \& Isotope study water \& gas Makushin Fs,Ff Motyka $1983 \mathrm{High}$ temp hydrothermal resources Aleut arc R,Fs, Ff Motyka 1984 Chem of water \& gas Mt Wrangell [abs.] Ff Motyka \& Moorman 1980 Assmt thermal spring S SE Ak [abs.] R,Fs Motyka \& Moorman 1981 Recon thermal spr Aleutian arc R,Fs,Ff Motyka Moorman 1987 Geotherm resourcers SE Ak R, Fs, FW Motyka \& Queen 1984 Makushin fluids samps \& well log Fs,Ff,Fw,PG Motyka \& others 1980 Assmt therm spr S SE Ak R, Fs Motyka \& others 1980 Geochemistry Pilgrim thermal waters Fs, Fw Motyka \& others 1981 Assmt thermal spring Aleutian arc R,Fs,Ff,Gr 
Motyka others 1982 Fluid geochem Hot springs Akutan Fs,Ff Motyka o others 1982 Fluld geochemistry Makushin area $\quad$ FG, Ff Motyka others 1983 .Fluld investigations Makushin area Fs, Ff Motyka \& others 1983 Geothermal resources of Alaska R, Fs, Ff, Fw Motyka \& others 1985 Geol geoc geophys Akutan *, Gs, Fs, Ps, RM, FE, DP Motyka others 1986 Geochem isot org mud volc copper R Fs, Ff, FW Motyka \& others 1986 Makushin well chem equil ib *, Fw, Fs, Ff, HA, RM Muffler 1979 Assmt geothermal resources U. S. R,Fs, HS Nava Morrison 1974 Note on hot springs interior Ak $R, F s$ Nehring \& others 1979 sulfate geotherm western U. S. Nichols Yehle 1961 Anal gas water Copper River basin Nichols \&ehle 1961 Mud volc Copper River basin $R, F s$ ogle $1976 \mathrm{Ak}$. hot spring site for small binary plant Poreda others 2981 He lsot vars Ak-Aleut arc [abs.] Reed others 1983 Data low temp geothermal systems Us Reeder 1982 Hydrothermal resources $N$ Unalaska Is Reeder 1986 Ground stability, spring water Broad Bay Relfenstuhl 1984 Geol \& geophys Goddard HS (thesis) Reifenstuhl 1986 Geol Goddard Hot Springs

Reitsema 1979 Gases of mud volc Copper RIver basin Fs FE Republ1c 1982 Unalaska Gtrml Prof IA Er,Hs,Fs,FE,Gs, Ps, DP, RM, HA Republ1c 1983 Unalaska Gtrml Proj IB Er,HS,Fs, Ff, Gs, Ps,DP, RM, HA Republic 1984 Unalaska Gtrml Proj II Er,HS,Fs, Fw, Gs, Ps, DP, RM, HA Republic 1985 Unalaska Gtrml Proj III *,Er,HS,FW,Gs,Ps,DP, RM, HA Sloan 1976 Chem anal Bailey Bay HS

sloan 1976 Chem anal Bell Is HS Sloan 1976 Chem anal Chlef Shakes HS Thompson \& Keith $1984 \mathrm{Cl} \& \mathrm{~F}$ in waters vTrs [abs Turner Forbes 1980 Geol geophy stdy Pilgri [abs. ] Ps, RM Fs, Fw Turner others 1980 Geothermal resources Alaska R, Fs Turner others 2983 sum, eval gthrm exp Copper R bsn Gs,Ps,FG,RM Updike $1986 \mathrm{Eng}$ geol, feasibil study Makushin *,Eg,Gs, Ps,Fs,DP waring 1917 Mineral springs Ak $\quad$ Fs,R Waring 1965 Thermal springs US \& world - a summary Fs Wescott \& Turner 1983 Geotherm expl E Copper R basin Ps,Gc,Fs, Fw Wescott \& Turner 1985 Geotherm invest Copper *, Gs, Ps, GC,DP,Fs, Fw White Williams 1975 Assmt geothermal resources US R,Fs,HS zles 1921 Hot springs in VTis

$\mathbf{F S}$

Volcanology $\quad$ V

Ach \& DeLong 1980 Magma evo I. Sitkin \& semisopochnol [abs.] PG Anonymous 1953 Activity of Trident Anonymous 1953 Eruption of Trident

Arce 1983 Volcanic hazards Makushin volcano (thesis) Eg Arce Economides 1982 Volcanic hazards Makushin Volcano Eg Barnes \& McCoy 1979 Mantle-derived CO2 in 2 phreatic expl F5,Ff,V Barrett 1978 Magnetic model of Augustine Volcano (thesis) $V, P s$ Barrett \& others 1977 Model of Augustine volcano [abs.] V,Ps Beget 1986 Prehistoric tephra at Augustine [abs.] V, Gs Benson \& Follett 1986 photogrammetry study Mt. Wrangell Benson \& Motyka 1978 Glac-volc interaction Mt. Wrangell Benson \& others 1975 Glac \& volc studies Mt. Wrangell 
Benson \& others 1985 Glacio-volcano studies Mt. Wrangell V Bingham 1967 Ice \& heat studies Mt. Wrangell (thesis) V,HS Bingham \& Benson 1967 Mt. Wrangell lce \& heat studies - V,HS Bingham \& Benson 1968 Ash temp variations Mt wrangell V,HS Bordet \& Tazieff 1963 Erupt of Ratmai \& Ignimbrites Bordet \& others 1963 Katma1

Brew \& others 1965 Eruptive history Mt. Edgecumbe [abs.] Byers \& Barth 1953 Volc activity Akun \& Akutan Islands Byers \& Brannock 1949 volc activity Umnak \& Great sitkin Is Case \& others 1980 Tertiary volc centers Ak Penin. Chaigneau \& Bordet 1963 Gas in glass in VTTS (Fr)

clark 1912 Katmai eruption Coats 1947 Geol N Adak Island coats $1947 \mathrm{GeOl} N$ Kanaga Is. Coats 1950 Volc activity Aleutian arc

Coats 1952 Magmatic different Adak \& Kanaga Islands Coats 1953 Geol Buldir Island Coats 1956 Geol N Kanaga Island

Coats 1956 Recon geol W Aleutian Islands Coats 1962 Magma type \& crustal structure Aleutian arc Coats \& others 1961 Geol recon Kiska Island Curtis 1955 Importance of Novarupta [abs.] Curtis 1968 stratigraphy of ejecta 1912 eruption Katma1 Dally 1912 Eruption of Katmai Daley \& Swanson 1985 Iow press fractionation Augustine [abs.] Dall 1870 Bogosloff volcano Dall 1884 New volcano island Dall 1889 Notes on Bogoslof island Davidson 1884 New Bogoslof volcano Davidson 1884 New volcano in Alaska Davidson 1893 Eruption of Veniaminof Davies \& Kienle 1986 Augustine eruption \& advice [abs.] Decker 1967 Invest at active volcanoes Detterman 1968 Volcanic activity Augustine Island Diller 1884 Volcanic sand Unalaska Doroshin 1870 Volcanoes, eruptions \& earthquakes Dumond 1979 People \& pumice Ak Penin. Edsall 1976 Trace elem in tephra Aleutians Eickelberger \& Hildreth 1986 Drilling in Katmai [abs.] Emanuel 1984 Hydro \& volc hazards Mt Spurr [abs.] Escher 1922 Lahar VTTS

Federman \& Scheidegger 1984 Distal tephra 1912 Novarupta

Fenner 1920 Geol Ratmal 1912 eruption [abs.]

Fenner 1920 Ratmai great eruption of 1912

Fenner 1923 Tuff deposit VTTS

Fenner 1923 Tuff deposit VTTS

Fenner 1926 Katmai magmatic province

Fenner 1930 Mt Katmal \& Mt Mageik

Fenner 1937 Tuffs of Katmal \& Yellowstone

Fenner 1950 Chemical kinetics Ratmai eruption

Ferrians \& others 1958 Pleist volc mudflow Copper River basin Fierstein \& Hildreth 1984 Pyroclastic deposits Novarupta [abs.] Flerstein \& Hilareth 1986 Novarupta ejecta [abs.] Finch 1935 Akutan volcano

Gr

Gr

PG

Gr

$\mathrm{V}, \mathrm{H}$

$P G$

$\mathrm{H}, \mathrm{V}$

$\mathrm{H}, \mathrm{V}$

$\mathrm{H}, \mathrm{V}$

$\mathrm{B}, \mathrm{V}$

$\mathrm{H}, \mathrm{V}$

$\mathrm{B}, \mathrm{V}$

$v, c$

$\mathrm{H}, \mathrm{V}$

$\mathrm{v}, \mathrm{c}$ $v, G s, P s$

$\mathrm{V}, \mathrm{H}$

$\mathrm{V}, \mathrm{H}$

PG

$V, \mathrm{H}$

$V$, E 
Forbes \& Kienle 1971 Augustine

Forbes \& Kienle 1971 Petro pre 1912 pyroclast VTTS [abs] PG,Gs,V Forbes \& others 1971 Seismicity Augustine [abs.]

Foresman 1970 Mud volcanoes Copper River basin (thesis)

Fournelle \& Marsh 1986 Shishaldin lavas [abs.]

Fry 1912 Mineral content volcanic ashes

Furst 1968 Recon petrol Mt Wrangell caldera (thesis)

Gosink \& Others 1986 Augustine ash [abs.]

Grewingk 1850 Historic geology NW North America (Ger)

Griggs 1918 Eruption of Katmai

Griggs 1918 VTTS mud flow

Griggs 1919 Character of Katmai eruption

Griggs 1919 Katmal \& VTTS

Griggs 1921 VTTS

Griggs 1922 VTTS

Griggs 1923 VTTS

Hamilton 1973 snow \& ice during Katmal eruption [abs.]

Henning others 1976 Alaska's volcanoes

Higbie 1975 VTTS

Hildreth 1980 Novarupta 1912 Petro of ejecta [abs.]

Ps, V

Gs

PG, $\mathrm{V}$

$\mathrm{V}, \mathrm{H}$

PG

$\mathrm{V}, \mathrm{H}$

$\mathrm{V}, \mathrm{H}$

$\mathrm{V}, \mathrm{H}$

$\mathrm{H}, \mathrm{V}$

$\mathrm{H}, \mathrm{V}$

$\mathrm{V}, \mathrm{H}$

$\mathrm{V}, \mathrm{H}$

$\mathrm{V}, \mathrm{H}$

$V, R$

Hildreth 19811912 eruption VTTS [abs.]

$P G$

PG

Hildreth 1983 zoned eruption 1912 VTTS

Hilareth \& Flerstein 1986 Novarupta near vent ejecta [abs.] V Hildreth \& Grunder 1980 VTTS comp \& 1sotope of ejecta [abs.] PG Hildreth \& others 1981 VTTS summary of strat \& petro of ejecta PG Hobbs \& others 1977 Eruption of Augustine

Hubbard 1931 World Inside a mountain

Hubbard 1935 Cradle of storms

Jaggar 1908 Evolution Bogoslof Volcano

Jaggar 1908 Evolution of Bogoslof [abs.]

Jaggar 1927 Eruption of Mageik

Johnson 1976 zoned magma chamber Augustine [abs.]

Johnson 1978 Magma mixing Augustine volcano (thesis)

Johnson 1978 Magma mixing Augustine volcano [abs.]

Johnson 1979 Volcanism at Augustine

Johnson 1980 Vole contr Cl to stratosphere

$\mathrm{V}$

Johnson \& Detterman 1979 Revision of eruptive history Augustine

Johnson \& Grunder 1980 vTTS Tuff II comp \& Lsot ejecta [abs.] V

Johnson \& Hildreth 1980 VTTS Tuff I Empl, comp \& weld [abs.] V

Johnson \& Hildreth 1980 VTTS comp \& isot of ejecta [abs.] V

Johnson o others 1977 Augustine Volc, evaluat hazards [abs.] V,Eg

Juhle 1955 Iliamna Volcano

Juhle \& Coulter 1955 Mt. Spurr eruption 1953

Katsul 1984 Okmok

Kay others 1982 Tectonic control of magmatism Aleut arc

Keith 1986 Hydrothermal alteration Novarupta [abs.]

Kennedy \& Waldron 1955 Geol Pavlof volcano

Kienle 1968 Gravity Survey Katmai (thesis)

Kienle 1969 Gravity traverse VTrS, Katmal [abs.]

Kienle 1972 Volc micro-quakes August ine [abs.]

Kienle 1974 Alaskan volcano studies esp. Augustine

Kienle 1986 Augustine volcano [abs.]

Kienle \& Forbes 1974 Ak volc studies Augustine

Kienle Forbes 1977 Augustine - Evolution of volcano 
Kienle \& Pulpan 1975 Tide caused quakes at Augustine [abs.] Ps,V Kienle \& Shaw 1977 Augustine erupt - Initial phase 1976 Kienle \& Swanson 1980 Volcanic hazards Augustine Kienle \& Swanson 1983 Volc E Aleut arc I Quat \& Holo cntrs Klenle \& Swanson 1983 Volc E Aleut arc Quat \& Holo centers kienle \& Swanson 1985 Volc hazards Augustine 2nd ed. Kienle \& others 1971 Microquake swarm Augustine [abs.] Kienle \& others 1978 Form. 2 maars behind volc arc [abs.] Kienle \& others 1978 Formation 2 maars Ak Penin prelim results Kienle others 1979 Shallow magma at Augustine Rienle \& others 1980 Ukinrek Maars 1977 eruption Kienle \& others 1981 subd \& magma E Aleut arc [abs.] Kienle \& others 1981 Volcanic centers Ratmal [abs.] Kienle \& others 1983 Magmatism subduction E Aleutian arc Kienle \& others 1986 Augustine \& tsunamis [abs.] Knappen 1933 Aniakchak \& Veniaminof volcanoes [abs.] Kodosky \& Keskinen 1986 Fumarole alt Augustine [abs.] Kosco 1981 Andesitic volcanism at Katmal Kosco 1981 Edgecumbe volc \& Katmai (thesis) Kubota \& Berg 1967 Magma in Ratmal range Lalla 1987 Selsmo \& thermal studies Augustine (thesis) Ialla \& Kienle 1974 Infrared thermometry Augustine [abs.] Lalla Kienle 1975 Microquakes, tremors at Pavlov [abs.] Ialla \& Kienle 1976 Thermal studies Augustine [abs.] Ialla \& Kienle 1978 Evolution seismicity Augustine [abs.] Ialla \& Kienle 1980 Problems volc seismo Augustine [abs.] Ialla * Kienle 1986 Sels therm precursors erupt Augustine V,Ps,HS Lawton 1909 Makushin sulfur deposits

IImke \& Beget 1986 Pyroclastic flows Augustine [abs.]

Lorenz 1982 Eruption Ukinrek Maars

MacGregor 1952 Eruptive mechanisms VTTS

Martin 1913 Eruption Katmal

Matumoto 1971 Selsm body waves Katmal a molten chmbr [abs.] Matumoto \& Molnar 1967 shadow effect $S$ waves Katmal [abs.] Matumoto \& Ward 1967 Microquake study Katma1

Mauk \& Rienle 1973 Microquake August ine earthtides

McNutt 1983 Activity Paviov Shumagin gap? [abs.]

McNutt 1984 Eruption \& stress Paviov [abs.]

McNutt \& Beavan 1981 Quakes at Pavlov earth tides

McNutt \& Beavan 1984 Pavlov sea level \& aseismic slip [abs.]

McNutt \& Mor1 1983 B type quakes Pavlov [abs.]

Menyaylov 1969 Comparison Bezymyany \& Katmai (Rus)

Merriam 2901 Birth of Bogoslof

Merriman 1910 Bogoslof new volcano

Metzner 1975 Magnetotelluric invest. Augustine (thesis)

Miller

1976 Augustine volcano

Niller

1978 Airfall pumice Aniakchak

Miller 19842 stage volcanism Ugashik-Peulik [abs.]

Miller \& Barnes 1974 Geotherm devel Ak [abs.]

Miller \& Barnes 1976 Geotherm develop Ak summary

Miller \& Smith 1975 Ash flows Ak Penin prelim rpt [abs.]

Milier \& Smith 19762 caldera forming eruptions Umnak

Miller \& Smith 1976 Ash flows Wrangell volcano

Miller \& Smith 1976 New volcanoes Aleutian arc

$\mathrm{HA}$,

Gr, H

$R, P G$

$\mathbf{V}, \mathbf{R}$

$V, P G$

\section{v} $v$ $\mathrm{V}$ (1) 
Miller \& Smith 1977 Moblle ash flows Aniakchak \& Flsher calds V M1ller \& Smith 1983 Calderas E Aleutian arc [abs.] Gr Motyka 1977 Katmal caldera geothermal activity v,Fs Motyka 1978 survelliance Katmal caldera crater lake v Motyka 1983 Thermal activity Mt Wrangell (thesis) V,HS,Ff Motyka \& Benson 1982 Flucts in heat flow Mt Wrangell [abs.] V,HS Motyka \& others 1977 Glac-volc investigations Katmal [abs.] V Motyka \& others 1978 Increased heat Mt Wrangell [abs.] HS Motyka \& others 1980 Kt Wrangell glac meas heat flow [abs.] $V, H S$ Mulier others 1954 Volcanic activity Katmal Myers 1979 Geol, petro Edgecumbe: trnsfrm fault volc (thesis) PG Myers \& Marsh 1981 Geol \& petrogen Edgecumbe volcanics PG Myers \& others 1986 Isot var Adak \& Atka volc plumb V,PG, Gr Nakamura \& others 1977 Volc tectonic stress orlent Aleut \& Ak $R, V$ Nye 1982 Wrangell volcs \& microplate accretion [abs.]

Nye 1983 Petro \& geochem okmok \& Wrangell volcs (thesis) , PG,V Nye 1986 Volcanic hazards, Makushin V, Eg Nye \& Reid 1986 Geochem pri lava Okmok Volc: arc magmagenesis PG Nye \& Swanson 1986 Chem strat magma plumb Makushin [abs] V,Gs,PG Nye Swanson 1987 Makushin magma chamber PG,Gs,V Nye * Turner 1986 Geology geochemistry Spurr [abs.] Gs,PG,V Nye \& others 1983 Parental magmas Okmok: arc magmagen [abs.] PG Okimura 1930 Eruption Katmai

* Page \& others 1982 Selsm Spurr, Redoubt, \& Ilamna [abs.]

searson 1977 Selsmic refr Augustine (thesis)

*. Pearson \& Kienle 1978 selsmic refr study Augustine [abs.] V,Ps

- Perfit \& others 1980 Model for fract in Aleut calc-alk suite PG

- Perrey 1866 Quakes \& volcanism Aleutians \& Ak Penin (Fr)

- Powers 1916 Changes in Bogoslof volc

. Powers 1953 Activity Aleut volcanoes

- Powers 1956 Activity AK volcanoes 1949-53

Powers 1958 Ak. Penin Aleut Is

$\therefore$ Prosser 1912 Volcanic road-bullding

Pulpan Kienle 1978 Selsmic \& volcanic risks, Alaska

Reck 1930 Review VTTS (Ger)

Reeder 1983 Prellim dating Holo volcanic E Aleut Is [abs.] V,Gr

Reeder 1984 Okmok

Reeder \& others 1977 Selsm Augustine volc [abs.]

Richter \& others 1984 Shleld volc wrangell Mts

Riehle 1985 Recon Holo tephra deposits upper Cook Inlet

Riehle others 1981 Lahars Crescent River Lower Cook Inlet

Robinson 1948 Exploring Aleutian volc

Scheldegger KuIm 1973 Cyclic Aleut volc ash DSDP 178 iab $V, H$

Scheldegger \& others 1977 Ash volc Aleut \& Kamchat arc [abs.] V

Schmincke Johnson 1977 Pyroclastlc flows Augustine [abs]

Schnell \& Sheridan 1986 Arctic gas aerosols-Augustine [abs.] V Self others 1978 Mechanisms deposits Ukinrek [abs.] Ps,Gs,V

Self \& others 1980 Ukinrek Mars II deposits \&ormation $v$

Shackelford 1983 Hist activity Pavlov Volc

Shipley 1919 VTTS

Shipley 1920 Ratmal gas encrustations

slebert \& others 1986 Debris avalanches Augustine [abs.]

simkin others 1981 Volcanoes of the World

Smith \& Shaw 1979 Igneous related geothermal systems

[abs. ] $\begin{array}{r}H A, F f, V \\ V \\ V \\ V, R \\ R, H S\end{array}$ 
Snyder 1954 Eruption Trident Katma1

Stewart 1975 Iate Cenozoic erupt Aleutians \&uril Is arcs

Stith others 1977 Nuee ardent Augustine Volc

Stone \& Kienle 1975 Pavlov

Stoney 1884 volcano in Bering Sea

Swanson B Blum 1984 Evol of volc centers Aleutian arc [abs]

Swanson \& Kienle 1982 Volc centers Katmai

Swanson \& others 1981 Geol \& petro Kaguyak Crater [abs.]

Swanson \& others 1983 Petro Makushin volc [abs.]

Swanson \& others 1986 Magmatic evolution Augustine [abs.]

Tams 1924 Katmal (Ger)

T111 1984 Redoubt-strat \& volc hazards [abs.]

Turner \& Nye 1986 Geochronology Mt. Spurr

Turner \& Swanson 1981 Continent rifting new model seward Pen Gr Turner \& Wescott 1986 Geotherm invest Mt. Spurr *,R,Ps,GC,V,Gs,RM Turner \& others $1986 \mathrm{Mt}$. Spurr geothermal project $R, G s, V$ Updike 1986 Eng geol, feasibil study Makushin *,Eg, Gs, Ps,Fs, DP Ward \& Matumoto 1967 sum volc \& seismic activity Katmai V,Pr Ward \& Ward 1966 Volc activity in Katmal Wendler 1967 Heat flow Mt. Wrangell

Wescott \& others 1986 Ice thickness Mt. Spurr summit

Wilcox 1953 Eruption Mt Spurr

Wilcox 1959 Volcanic ash falls Alaska

Williams \& others 1956 Mt Katma1 \& VTTS new interp 1912 eruptn

Wilson \& Forbes 1969 Infrasonic waves \& volc erupt [abs.]

Wilson \& Forbes 1969 Infrasonic waves Ak volc eruptions

Wilson \& Kienle 1976 Infrasonic signals Augustine volc [abs.] V Yehle \& Nichols 1980 Recon map Chetaslina debris flow Copper $R \quad V$ Yount 1984 Redoubt mineralogy \& chem [abs.] V,PG Yount \& others 1985 Eruption Mt Veniaminof Yount \& others 1985 New Holo vent Port Moller \& Stepovak Bay Q V

Well chemistry FW

Biggar 1974 Geol \& geophys stdy at Chena HS (thesis) Gs,Ps,Fs,Fw BIIss 1983 Ak basic data thermal springs \& wells R, Fs, FW East 1982 Geotherm investigation Manley HS (thesis) Fs, Fw, Gs, Ps Hawkins \& Motyka 1985 stat \& chem anal H2O Copper River bsn Fs, FW Motyka \& Moorman 1987 Geotherm resourcers SE Ak R, Fs, FW Motyka \& Queen 1984 Makushin fluids samps \& well log Fs,Ff,Fw,PG Motyka \& others 1980 Geochemistry Pilgrim thermal waters Fs, Fw Motyka \& others 1983 Geothermal resources of Alaska R,Fs,Ff, Fw Motyka o others 1986 Geochem isot org mud volc copper R Fs,Ff, Fw Motyka \& others 1986 Makushin well chem equilib *,Fw,Fs, Ff, HA, RM Queen 1987 Alt, H2O-rock equil, Makushin (thesis) HA, FW, Gs, GC, HS Republic 1984 Unalaska Gtrml Proj II Er,HS, Fs, Fw, Gs, Ps, DP, RM, HA Republic 1985 Unalaska Gtrml Proj III *,Er,HS,Fw, Gs,Ps, DP, RM, HA Turner \& Forbes 1980 Geol geophy stdy Pilgrim *,Gs,Ps, RM, Fs, Fw, HS Wescott \& Turner 1983 Geotherm expl E Copper R basin Ps,GC,Fs, Fw 


\section{ALASKA GEOTHERMAL BIBLIOGRAPHY}

\section{TABIES}


Table 1: Abbreviations used in short references.

\begin{tabular}{|c|c|}
\hline $\begin{array}{l}\text { \& } \\
= \\
\text { > } \\
\text { abs } \\
\text { adj } \\
\text { aeromag } \\
\text { Ak. } \\
\text { Aleut } \\
\text { alk, alter } \\
\text { alt, and } \\
\text { anal } \\
\text { assim } \\
\text { assmt } \\
\text { Augst } \\
\text { basn, bsn } \\
\text { bdrck } \\
\text { cald } \\
\text { Can } \\
\text { cent, cntr, c } \\
\text { chmbr } \\
\text { chem } \\
\text { Cl } \\
\text { classif } \\
\text { cmplx } \\
\text { comp } \\
\text { cond } \\
\text { conduct } \\
\text { contr } \\
\text { correl } \\
\text { cr } \\
\text { Cret } \\
\text { DSDP } \\
\text { dep, depos } \\
\text { devel } \\
\text { different } \\
\text { dist } \\
\text { E } \\
\text { econ } \\
\text { elect } \\
\text { elem } \\
\text { empl } \\
\text { eng } \\
\text { envir, environ } \\
\text { equil } \\
\text { erupt } \\
\text { est } \\
\text { eval } \\
\text { evid } \\
\text { evo, evol }\end{array}$ & $\begin{array}{l}\text { and } \\
\text { less than } \\
\text { equal to } \\
\text { greater than } \\
\text { abstract } \\
\text { adjacent } \\
\text { aeromagnetic } \\
\text { Alaska } \\
\text { Aleutians } \\
\text { alkaline } \\
\text { alteration } \\
\text { analysis } \\
\text { assimilation } \\
\text { assessment } \\
\text { Augustine } \\
\text { basin } \\
\text { bedrock } \\
\text { caldera } \\
\text { Canada } \\
\text { center, central } \\
\text { chamber } \\
\text { chemical, chemistry } \\
\text { Chlorine } \\
\text { classification } \\
\text { complex } \\
\text { composition, compaction } \\
\text { condensates } \\
\text { conductivity } \\
\text { contribution } \\
\text { correlation } \\
\text { creek } \\
\text { Cretaceous } \\
\text { Deep Sea Drililng Project } \\
\text { deposit(s), depositional } \\
\text { development } \\
\text { differentiation } \\
\text { district } \\
\text { east, eastern } \\
\text { economic } \\
\text { electrical } \\
\text { element } \\
\text { emplacement } \\
\text { engineering } \\
\text { environment } \\
\text { equilibria(ium) } \\
\text { eruption } \\
\text { especialiy, estimates } \\
\text { evaluation } \\
\text { evidence } \\
\text { evolve(d), evolution } \\
\text { eve }\end{array}$ \\
\hline
\end{tabular}


expl

F

feasibil

fluct

form

Fr

fract

frm

fum

geochem

geochron

geol

geomorph

geoph (Ys)

Ger

glac, glacio

grad

grav

gthrm, geotherm

$\mathrm{H}_{2} \mathrm{O}$

He

$\mathrm{Hg}$

hist

Holo

HS

hwy

hydro

hydrothrm

ig

ind $x$

inter ( $p)$

invest

is

isot

$\mathrm{K}$

$\mathrm{R} / \mathrm{Ar}$

KGRA

I

I1th

mag

magma

magmagen

Mak

meas

meta

min

N

NA

NE

NPRA explosions, explosive, explanation, exploration

Fluorine

feasibility

fluctuations

formation

French

fractionation

from

fumarole

geochemlstry, geochemical geochronology geology

geomorphology

geophysics, geophysical

German

glacial, glactological

gradient

gravity

geothermal, geothermometry

water

Helium

Mercury

historic

Holocene

Hot Spring

highway

hydrology, hydrological

hydrothermal

Igneous

Index

interpretation

investigation

island

Isotope, 1sotopic

Potassium

Potassium / Argon

Known Geothermal Resource

Area

lower

I1 thologic(al)

magnetic

magmatism

magmagenesis

Makushin

measure, measurements

metamorphic, metamorphism

mineral

north, northern

North America ( $n$ )

northeast, northeastern

National Petroleum

Reserve Alaska 


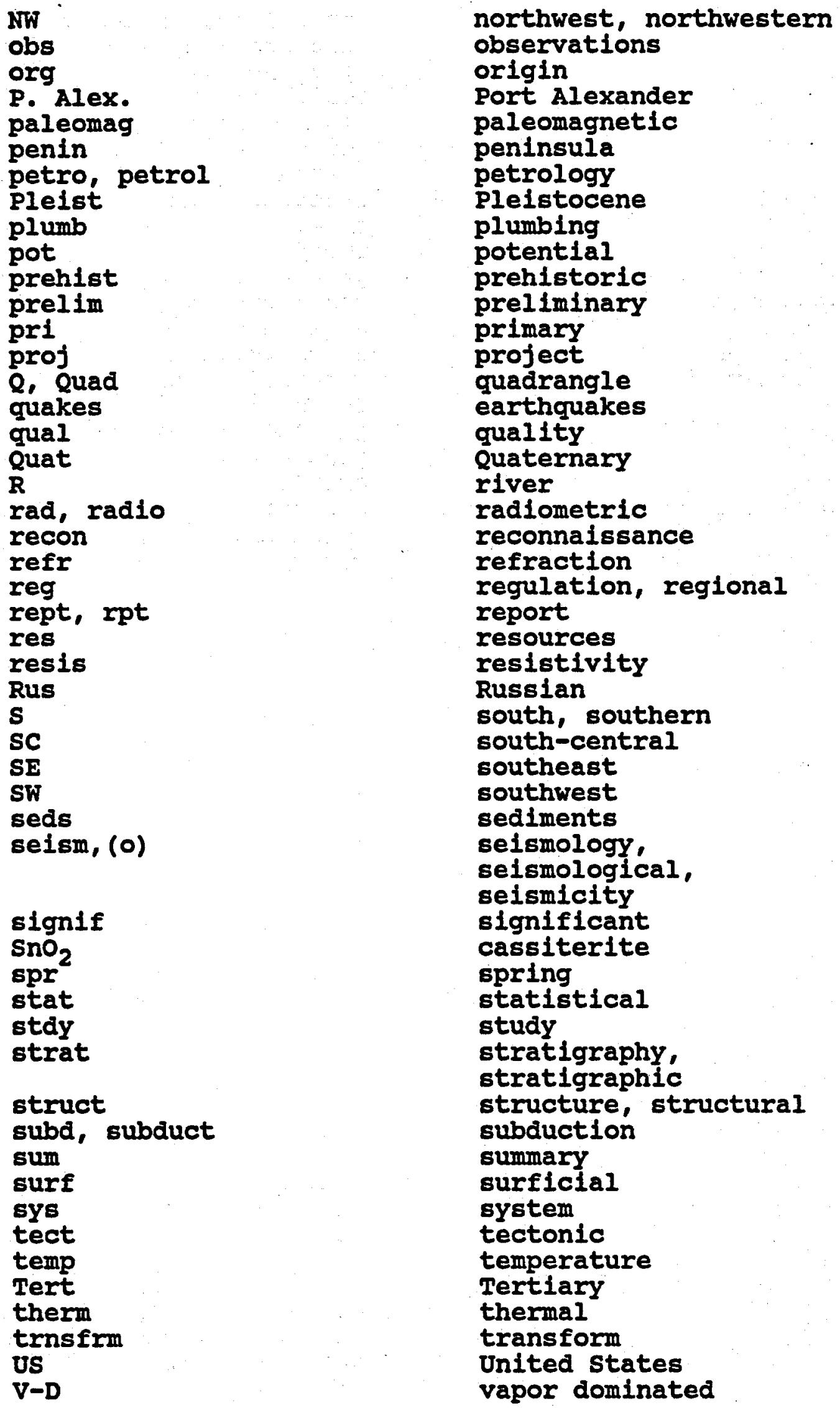


VTTS

var

volc

W

weld

Wisc
Valley of 10,000 smokes variation

volcantc, volcanological, volcano

West, western

welding

Wisconsinian 
Table 2. Codes used in the short references.

Code

C

DP

$\mathbf{E F}$

Eg

Er

Ff

Fs

FW

Gc

Gr

Gs

H

HA

HS

PG

$\operatorname{Pr}$

Ps

R

RM

V
Topic

Cultural, socio-economic data, environmental studies

Development and planning

Economic feasibility studies

Engineering geology, hazard studies

Engineering - reservoir

Fluid chemistry - fumaroles

Fluid chemistry - springs

Fluid chemistry - wells

Exploration geochemistry

Geology - regional study

Geology - site specific study

Historic report

Hydrothermal alteration study, includes fumarolic encrustations

Heat flow studies and estimates of thermal energy contents

Petrology and geochemistry of rocks

Geophysics - regional study

Geophysics - site specific study

Regional geothermal study

Resource model

Volcanology

Final report. For those areas with numerous interim and preliminary reports, * indicates a synthesis of all previous work. 
Table 3. Listing of geothermal sites in Alaska with the codes used on the NOAA map. See reference Motyka and others 1983, Geothermal resources of Alaska. Nine additional sites are included here.

Codes AA - Aleutlan Arc and lower Alaska Peninsula

\begin{tabular}{|c|c|}
\hline $\begin{array}{l}19 \\
20 \\
21 \\
22 \\
23 \\
24 \\
25 \\
26 \\
27\end{array}$ & $\begin{array}{l}\text { L1ttle sitkin } \\
\text { Semlsopochnol } \\
\text { Kanaga } \\
\text { Adak } \\
\text { Great sitkin } \\
\text { Korovin } \\
\text { Kliuchef } \\
\text { Milky River } \\
\text { Seguam } \\
\text { Chuginadak } \\
\text { Kagamil } \\
\text { Geyser Bight } \\
\text { Hot Springs Cove } \\
\text { Partov Cove } \\
\text { Okmok Caldera } \\
\text { Makushin Volcano } \\
\text { Glacier Valley } \\
\text { Makushin Valley } \\
\text { Summer Bay } \\
\text { Summer Bay Well } \\
\text { Akutan Volcano } \\
\text { Hot Springs Bay } \\
\text { Akun Strat1 } \\
\text { Shishaldin } \\
\text { False Pass } \\
\text { Kenmore } \\
\text { Egg Island } \\
\text { Cold Bay } \\
\text { Emmons Lake } \\
\text { Hague } \\
\text { Pavlov } \\
\text { Port Molier } \\
\text { Kupreanoff } \\
\text { Aniakchak } \\
\text { Mother Goose } \\
\text { Chuginagak } \\
\text { Ukinrek } \\
\text { Gas Rocks } \\
\text { Bogoslof }\end{array}$ \\
\hline
\end{tabular}




$\begin{array}{ll}\text { Codes NC - North Central Alaska } \\ 1 & \text { Pilgrim Springs } \\ 2 & \text { Pilgrim Wells } \\ 3 & \text { Serpentine } \\ 4 & \text { Iava Creek } \\ 5 & \text { Battleship Mountain } \\ 6 & \text { Rwiniuk } \\ 7 & \text { Clear Creek } \\ 8 & \text { Granite Mountain } \\ 9 & \text { Hawk } \\ 10 & \text { South } \\ 11 & \text { Upper Division } \\ 12 & \text { Iower Division } \\ 13 & \text { Dulbai } \\ 14 & \text { Sun Mountain } \\ 15 & \text { Reed River } \\ 16 & \text { Hornor } \\ 17 & \text { Melozi } \\ 18 & \text { Pocahontas } \\ 19 & \text { Tunalkten Lake } \\ 20 & \text { Little Melozitna } \\ 21 & \text { McQuesten } \\ 22 & \text { Ishtalitna } \\ 23 & \text { Kilo } \\ 24 & \text { Upper Ray River } \\ 25 & \text { Kanuti } \\ 26 & \text { Lower Ray River } \\ 27 & \text { Manley } \\ 28 & \text { Manley Wells } \\ 29 & \text { Hutlinana } \\ 30 & \text { Dall } \\ 31 & \text { Tolovana } \\ 32 & \text { Chena } \\ 33 & \text { Circle } \\ 34 & \text { Blg Windy } \\ 35 & \text { Okpilak } \\ 36 & \text { Red Hill Spring } \\ 37 & \text { Inmachuk } \\ 38 & \text { Upper Noatak } \\ 39 & \text { Arrigetch } \\ 40 & \text { Tetlin } \\ 41 & \text { Minook } \\ & \end{array}$



Peninsula

Codes SC - South Central Alaska and upper Alaska

\begin{tabular}{|c|c|}
\hline $\begin{array}{l}2 \\
2 \\
3 \\
4 \\
5 \\
6 \\
7 \\
8 \\
9 \\
10 \\
11 \\
12 \\
13 \\
14 \\
15 \\
16 \\
17 \\
18 \\
29 \\
20 \\
21 \\
22 \\
23 \\
24\end{array}$ & $\begin{array}{l}\text { Ophir } \\
\text { Chuilnuk } \\
\text { Mt. Martin } \\
\text { Mt. Magelk } \\
\text { Mt. Griggs } \\
\text { Katmal Caldera } \\
\text { Mt. Trident } \\
\text { Snowy Mt. } \\
\text { Kukak } \\
\text { Mt. Douglas } \\
\text { Augustine } \\
\text { Iliamna } \\
\text { Redoubt } \\
\text { Mt. Spurr } \\
\text { Wiliow Well } \\
\text { Iower Klawasi } \\
\text { Upper Klawasi } \\
\text { North Crater Mt. } \\
\text { Copper Glacier } \\
\text { Novarupta } \\
\text { Kaguyak } \\
\text { Tatiawiksuk } \\
\text { Cheeneetnuk } \\
\text { White Mountain }\end{array}$ \\
\hline
\end{tabular}

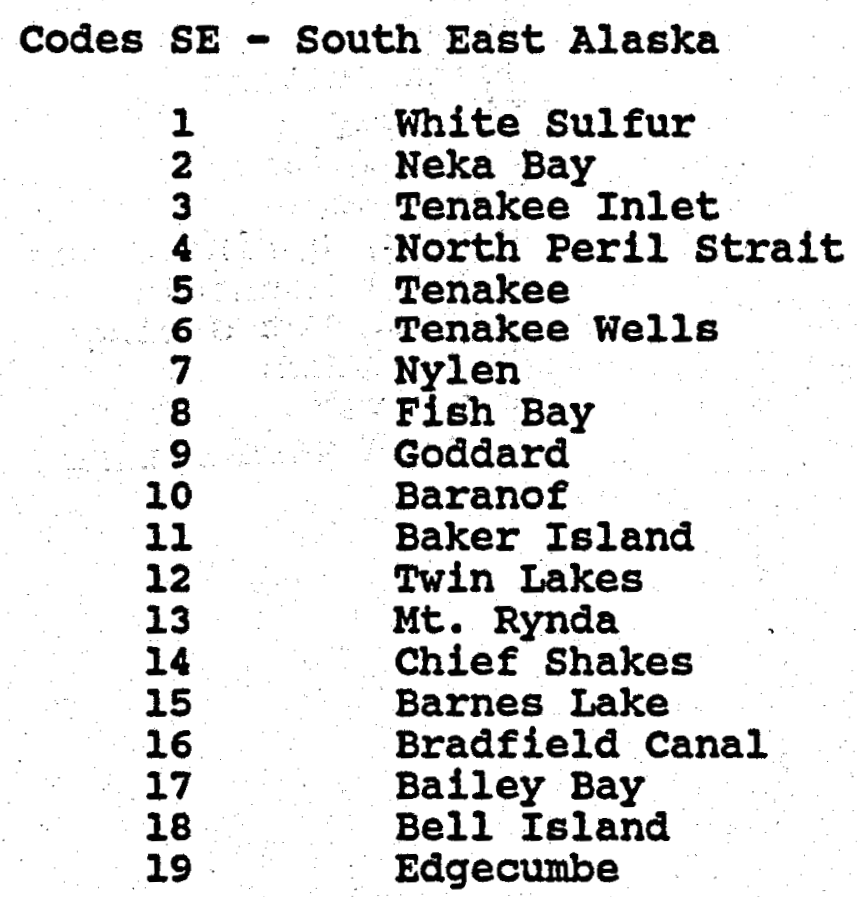


Table 4. Ifst of aliases

\author{
Name of spring as used \\ in this report. \\ Akun strait \\ Aniakchak \\ Baker Island \\ Barnes Iake \\ Battleship Mountain \\ Big windy \\ Chief Shakes \\ circle \\ Dulbai \\ Egg Island \\ False Pass \\ Goddard \\ Granite Mountain \\ Hague \\ Renmore \\ Kwiniuk \\ Lower Division \\ Lower Klawasi \\ Manley \\ Melozi \\ Milky River \\ Minook \\ Mt. Rynda \\ Neka Bay \\ Partov Cove \\ Pilgrim \\ Serpentine \\ South \\ Tenakee \\ Twin Lakes \\ Upper Ray \\ White sulfur
}

Names applied to same spring

in previous literature.

S.W. Akun

Surprise Iake

Craig, Dalton

Paradise

Mt. Kachauik

Wolfe

Shakes

Arctic Circle Hot springs

Dulbatna Mt., LeDonne

Amak

Morzhovoi

sitka Hot springs

Sweepstakes

near Paviov

stan Christianson

Elim

Division, Souby, Davidson

Shrub (Drum Group)

Baker

Melozitna

Atka

Conway

South stikine

Nika Bay

Umnak Island

Kruzgumepa

Arctic, spring creek

Purcell Mountain

Hooniah Hot Spring

West Shakes

Ray River

Hooniah warm spring 



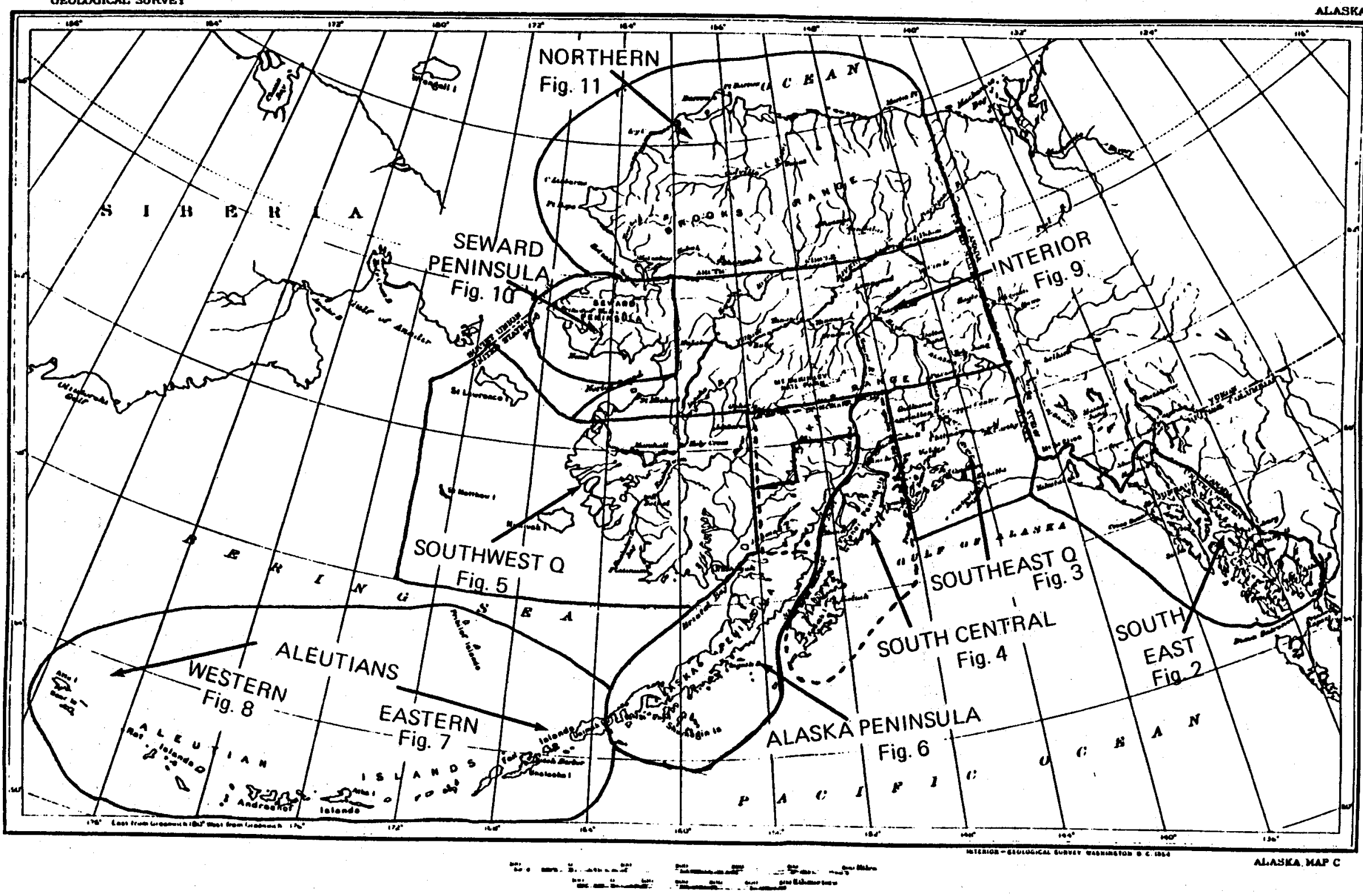

Fig. 1. Map of Alaska divided into the 10 geographical regions listed in section 4. Figures $2 \cdot 11$ are enlargements of each of these 


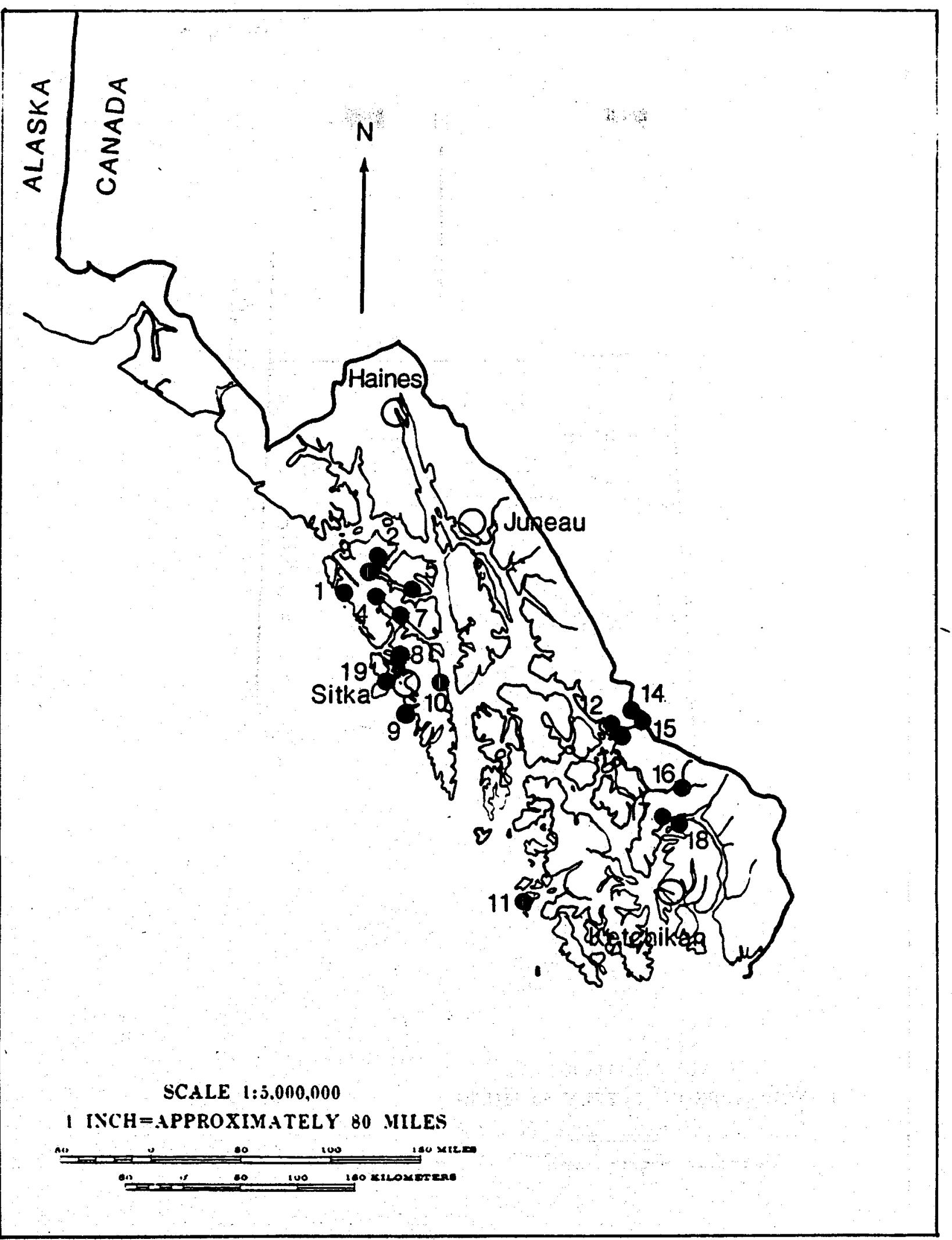

Fig. 2. Geothermal spring localities in the region referred to as Southeastern. The numerals correspond to those prefixed by SE on the NOAA map. 


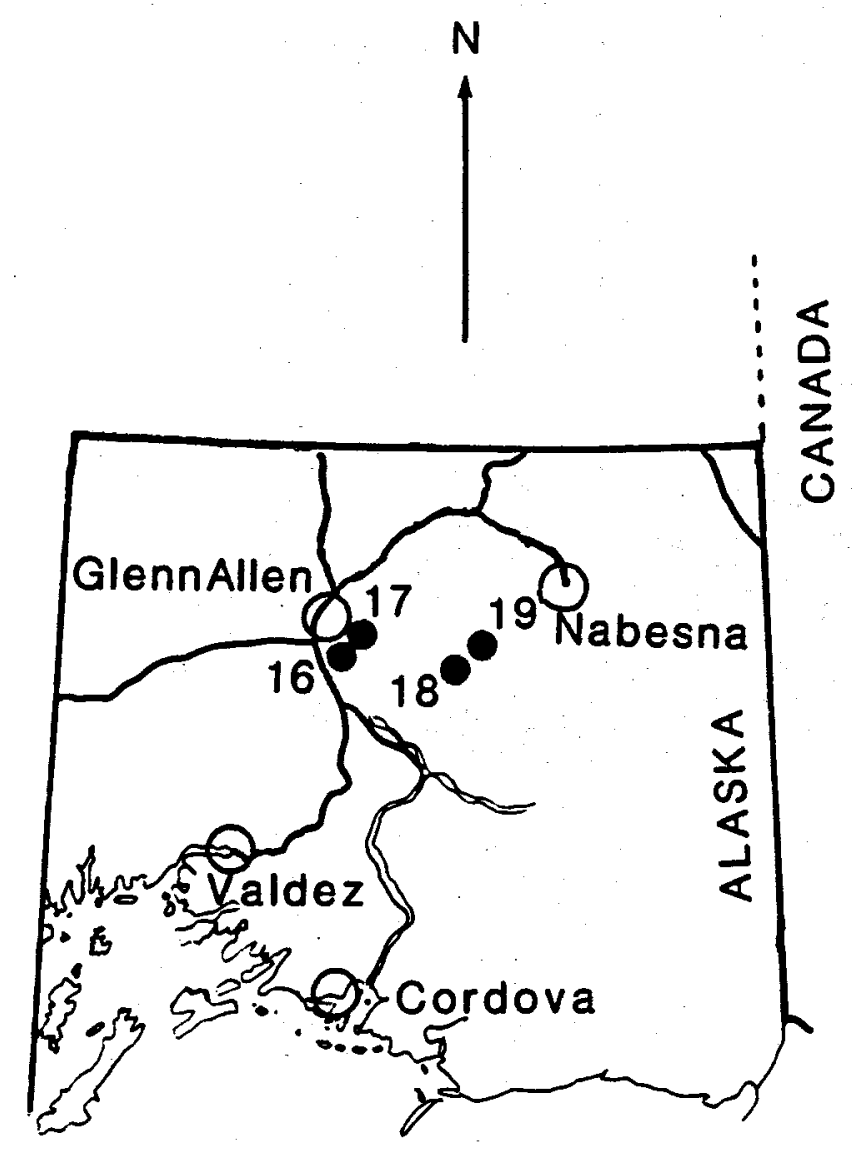

SCALE 1:5.0100.000

1 IXCH $=A$ APPROXIMATELY 80 MILES

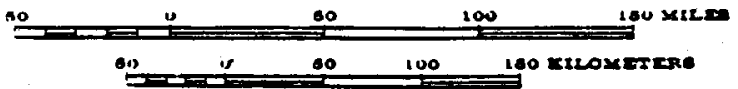

Fig. 3. Geothermal spring localities in the region referred to as Southeast Quadrant. The numerals correspond to those prefixed by SC on the NOAA map. 

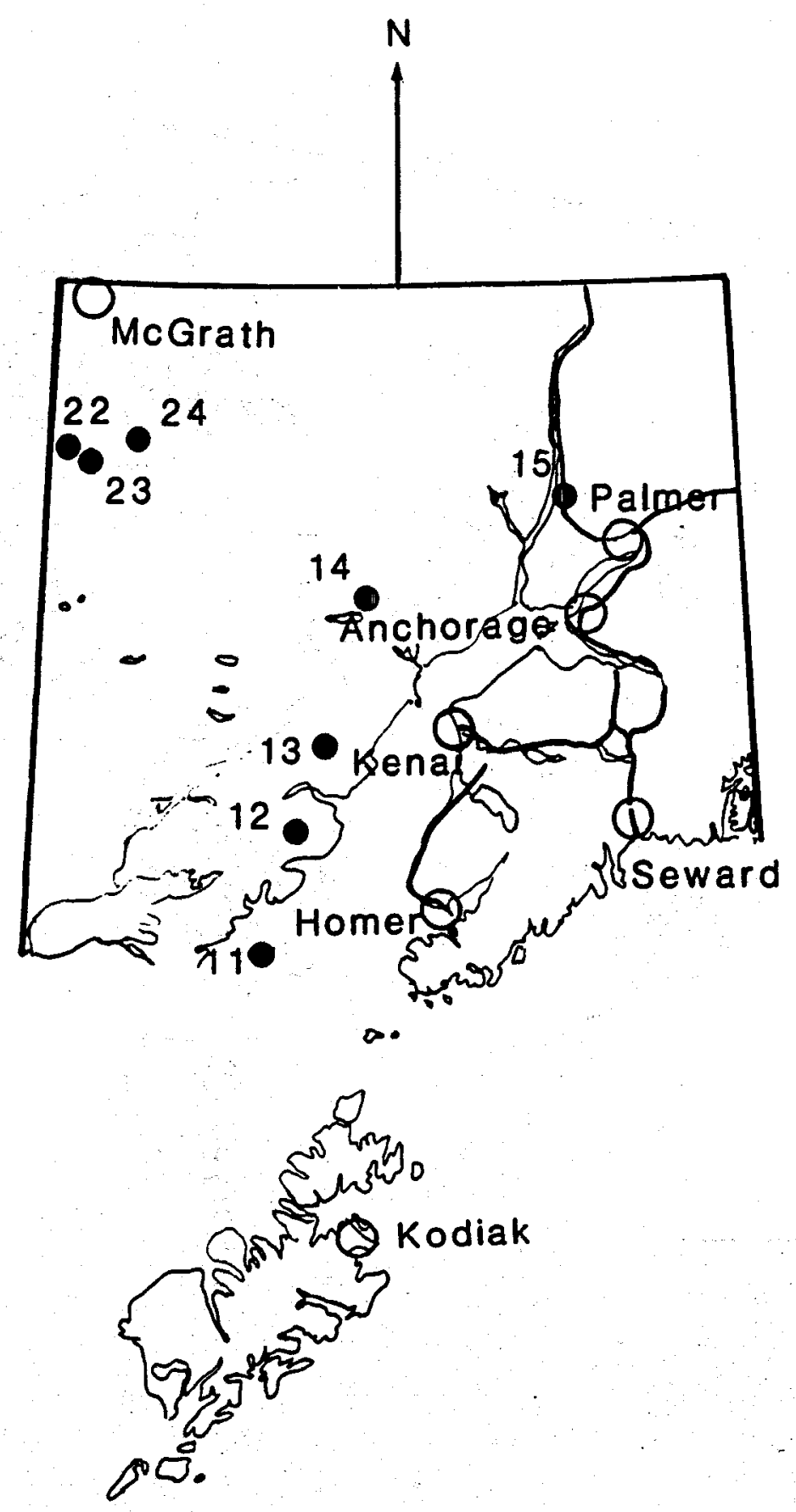

SCALE $1: 5.000 .000$

1 INCH=APPROXIMATELY 80 MILES

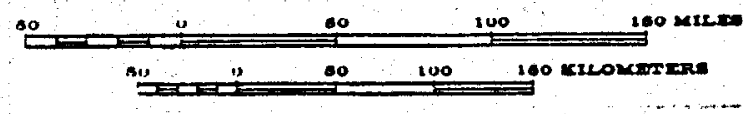

Fig. 4. Geothermal spring localities in the region referred to as South Central. The numerals correspond to thsoe prefixed by SC on the NOAA map. 


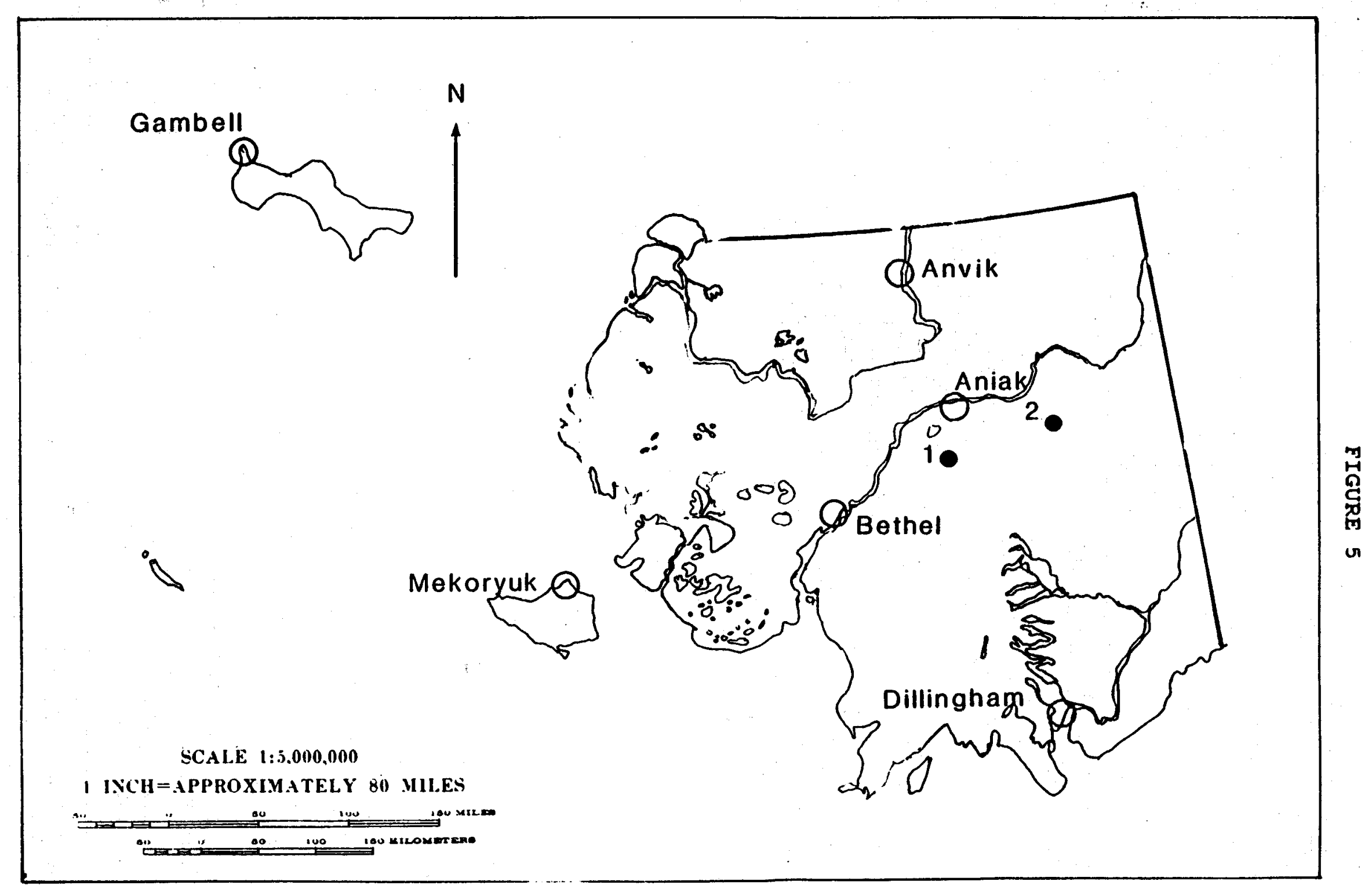

Fig. 5. Geothermal spring localities in region referred to as Southwest Quadrant. The numerals correspond to those prefixed by SC on the NOAA map. 


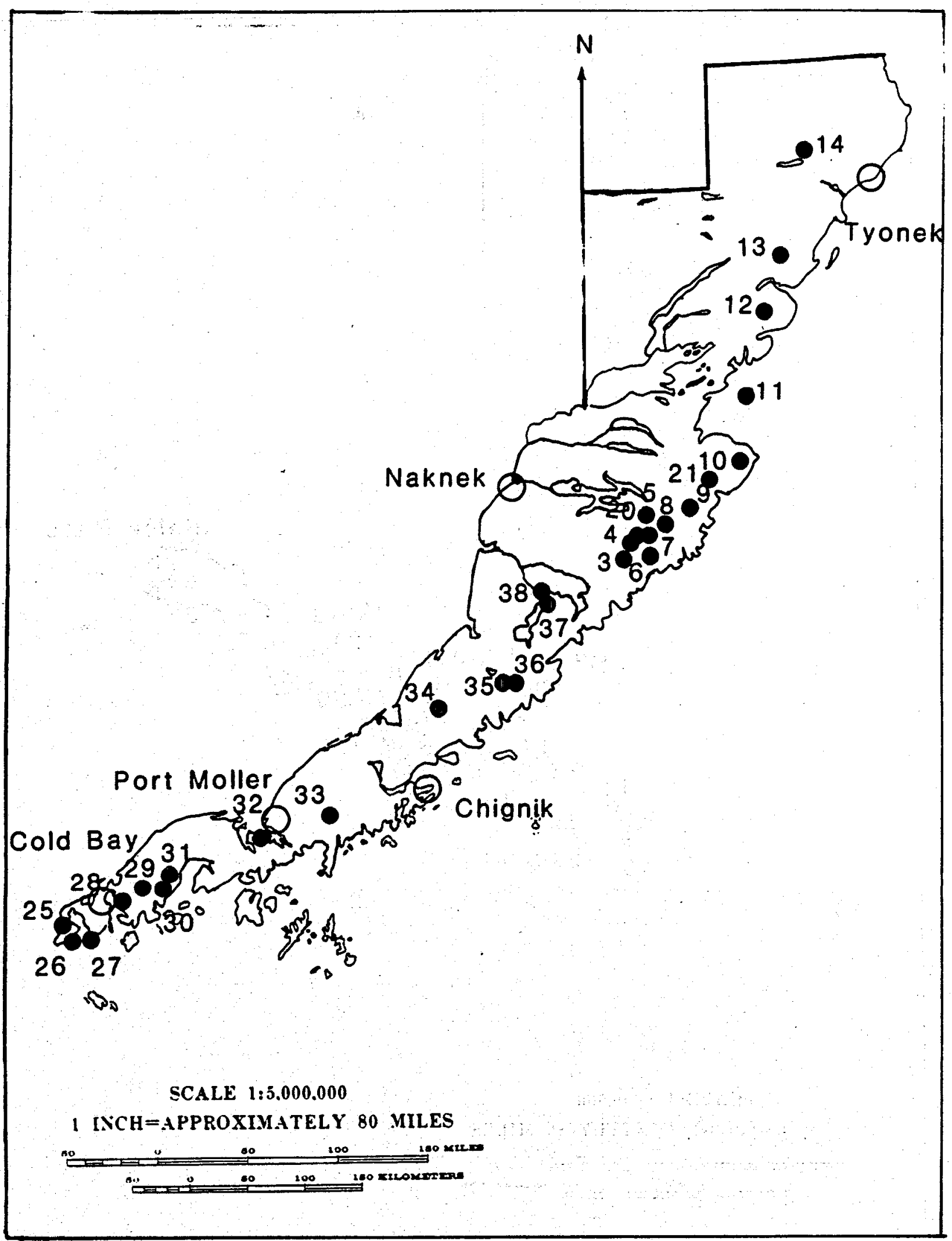

Fig. 6. Geothermal spring localities in the region referred to as Alaska Peninsula. Numerals 1-14 correspond to those labeled SC on the NOAA map, and 25-38 correspond to those labeled AA. 


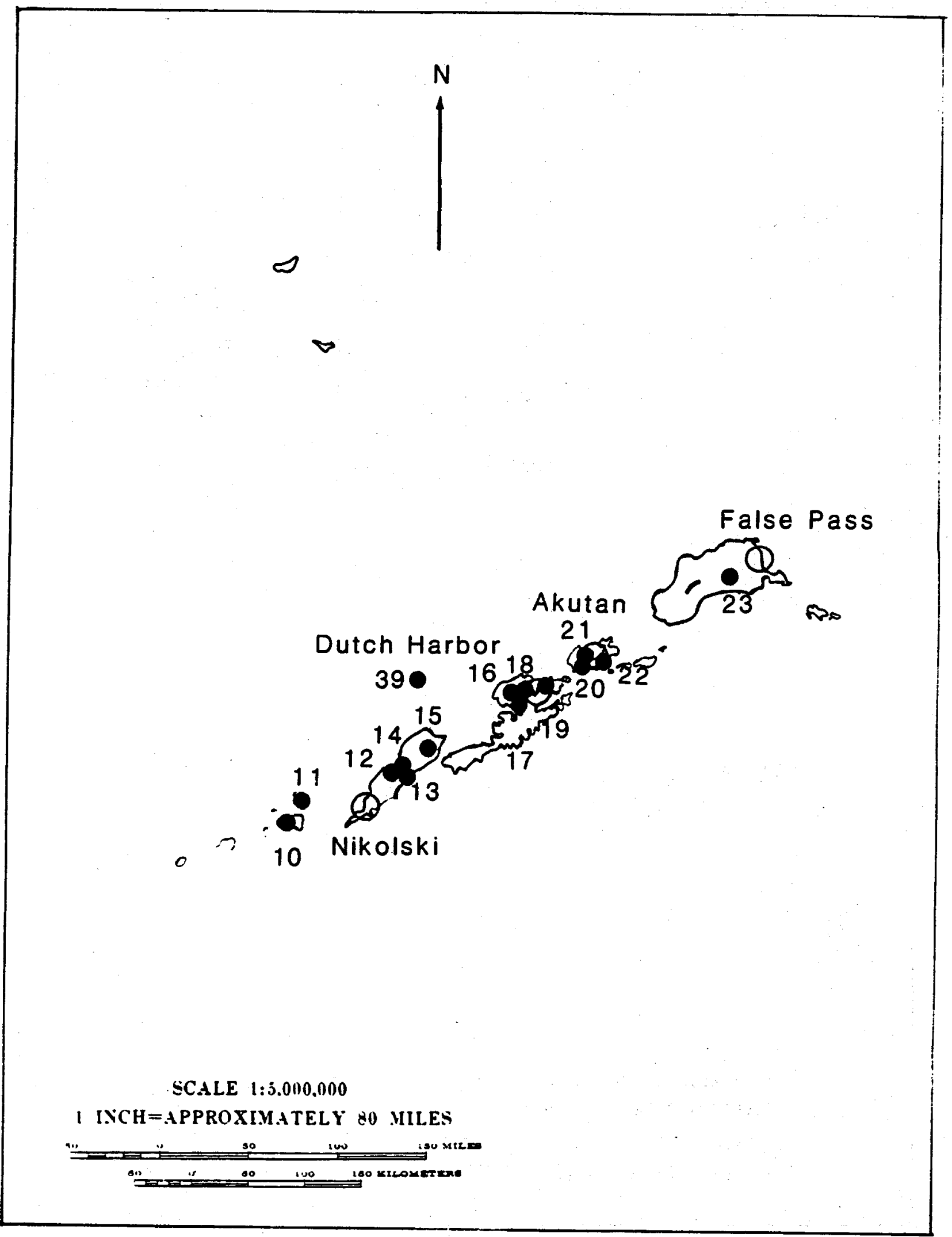

Fig. 7. Geothermal spring localities in the eastern portion of the region referred to as the Aleutians. The numerals correspond to those prefixed by AA on the NOAA map. 


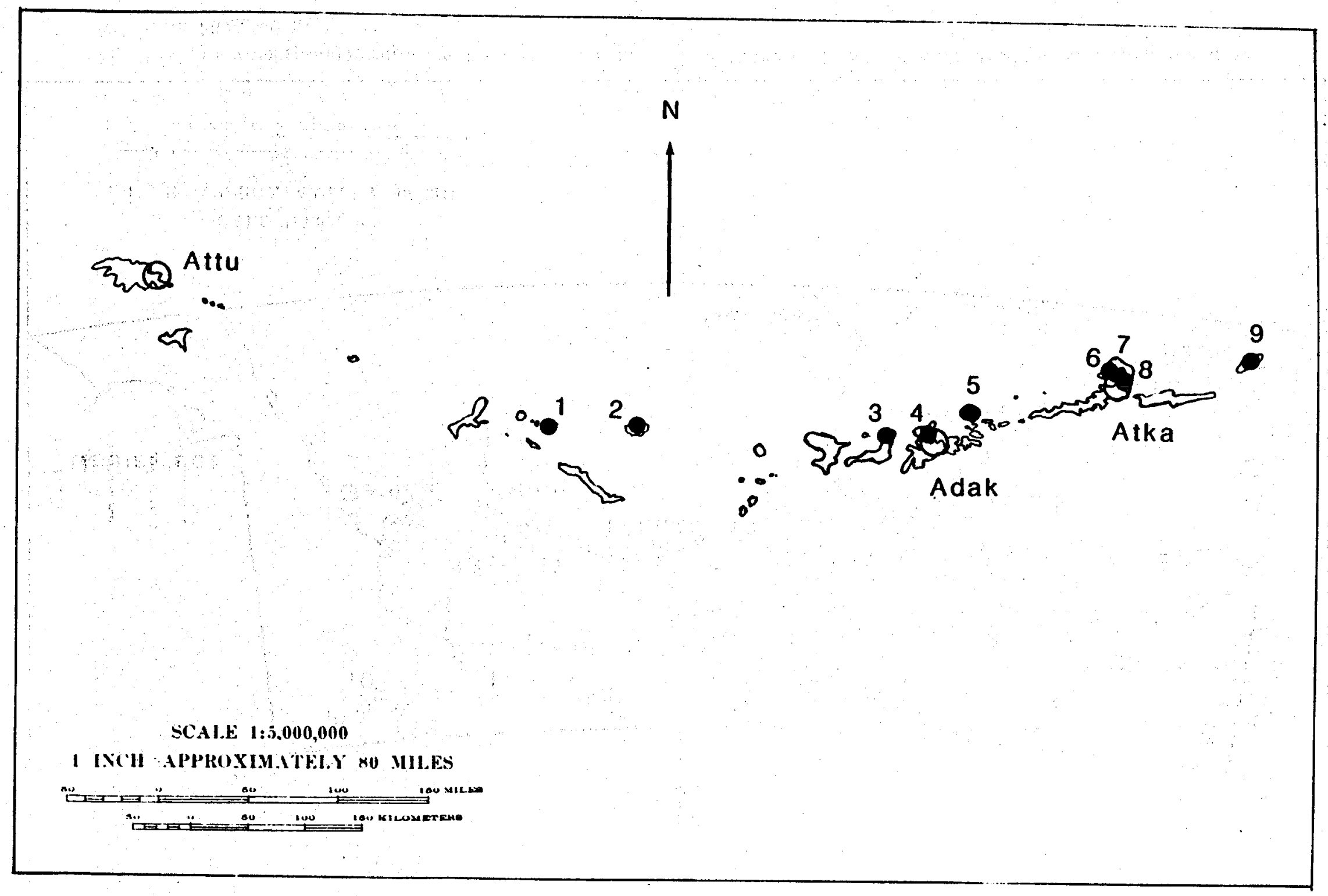

Fig. 8. Geothermal spring localities in the western portion of the region referred to as the Aleutians. The numerals correspond 10 those prefixed by AA on the NOAA map. 


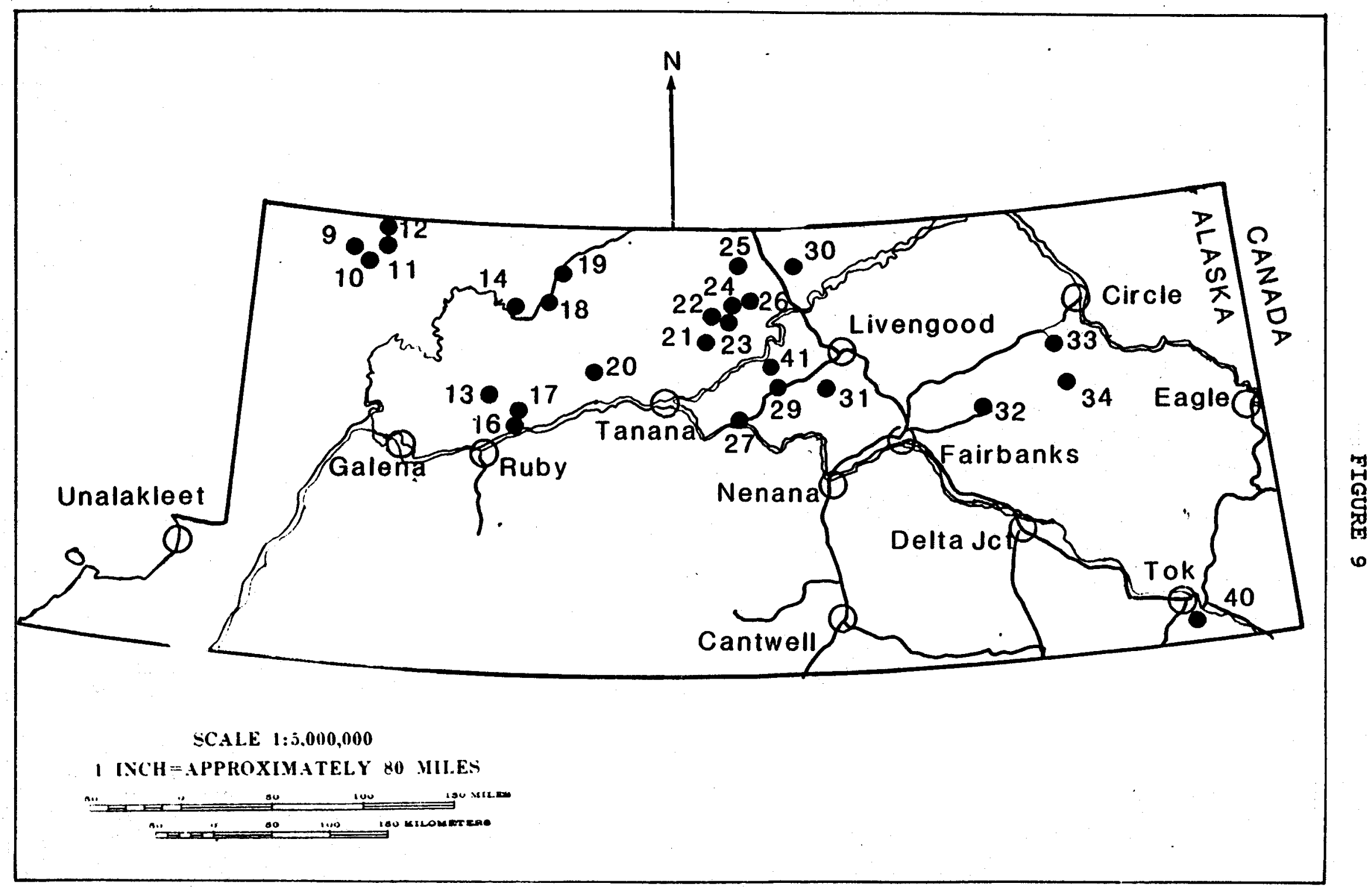

Fig. 9. Geothermal spring localities in the region referred to as the Interior. The numerals correspond to those prefixed by NC on the NOAA map. 


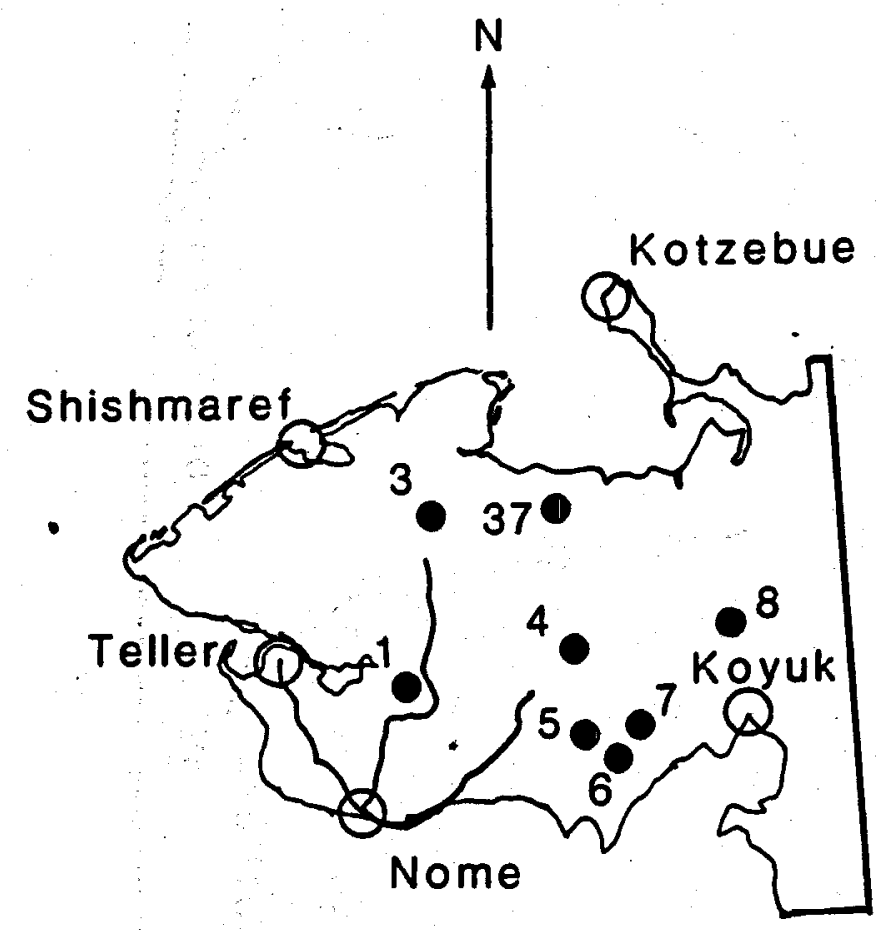

SCALE $1: 3.000,000$

1 INCH = APPROXIMATELY 80 MILES

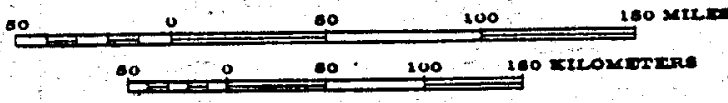

Fig. 10. Geothermal spring localities in the region referred to as the Seward Peninsula.

The numerals correspond to those prefixed by NC on the NOAA map. 


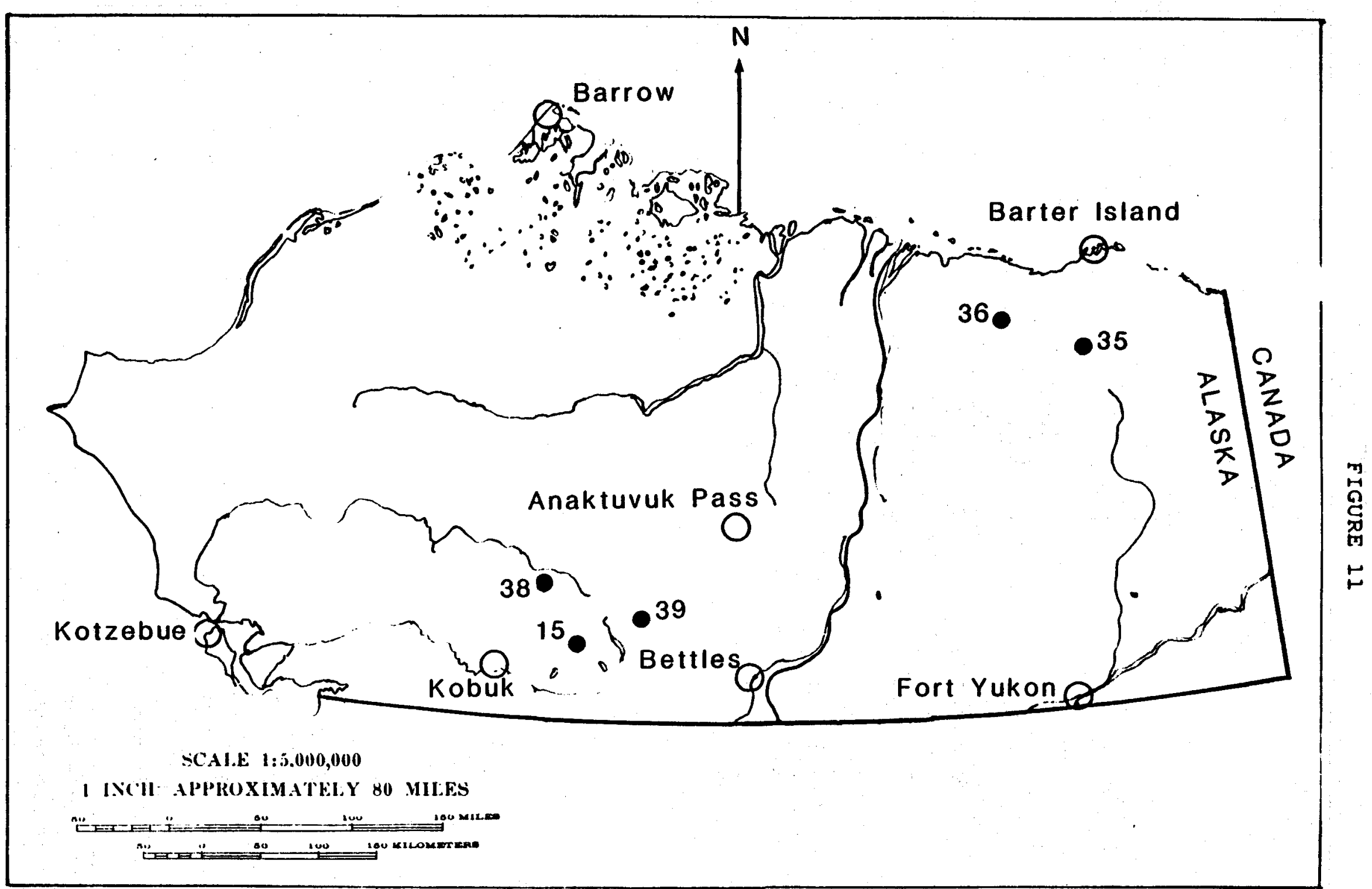

Fig. 11. Geothermal spring localities in the region referred to as Northern. The numerals correspond to thse those prefixed by NC on the NOAA map. 
AIASKA GEOTHERMAL BIBLIOGRAPHY

\section{APPENDICES}


APPENDIX A - MAJOR GEOTHERMAL PROJECTS IN ALASKA

The first extensive compilation of information on Alaskan thermal springs was done by Waring, 1917. Since then many additional thermal springs have been discovered and sampled. Several data compllations on Alaskan thermal springs have been published which included additional chemical data that had become available. The most notable of these publications include Miller, 1973, Gassaway and Abramson, 1977, and Turner \& others, 1980.

The Alaska Division of Geological and Geophysical surveys began its assessment of geothermal resources in Alaska in 1979. This program included reconnaissance investigations of as many known thermal sites as possible. Major funding for this project was provided by the state of Alaska and the U. S. Department of Energy. over 85 of the approximately 120 known thermal sites have now been visited with the major portion of this reconnaisance work being performed between 1979 and 1982 . The reconnaisance survey of a thermal site usually included reconnalsance of local geology, geochemical sampling of the thermal fluids, and meaurements of vent temperatures and rates of discharge. The location and a summary of thermal sites in Alaska can be found on the statewide geothermal resources map $(1: 2,500,000)$ ( Motyka and others, 1983). More detailed, technical regional geothermal resources maps at a scale of $1: 1,000,000$ are currently in preparation. The results of the reconnaissance investigations of thermal sites in the Aleutian Islands and Alaska Peninsula are reported in Motyka and others, 1981; and for southem southeast Alaska in Motyka and others, 1980. Our geochemical analyses of thermal spring waters in Alaksa have also been reported in Bliss, 1983.

\section{ADAK}

Saline thermal springs emanate along the Bering sea coast at the base of Mount Adagdak, a Tertiary-Quaternary volcanic center located northwest of the Adak Naval Base.

Geothermometers applied to the spring waters give reservoir temperature estimates of $160^{\circ}$ - $190^{\circ} \mathrm{C}$. Exploratory arilling on the flanks and base of Mount Adagdak was undertaken by the U. S. Navy in 1977. Temperature gradients measured as high as $80^{\circ} \mathrm{C} / \mathrm{km}$ and the temperature at the bottom of one 600 In deep hole was $66^{\circ} \mathrm{C}$. There has been no further exploration since then but the $U$. S. Navy is considering re-examining the Adak area's geothermal potential. Adak, a strategic 
military base, has a population of over 3,000 people making it the largest settlement in the Aleutian Islands.

Agencies involved:

Department of the Navy, Naval Weapons Center, Energy Program Management Office

Department of the Navy, Adak Naval station

Alaska Division of Geological \& Geophysical surveys

U. S. Geological Survey, Alaska Branch

U. S. Fish and Wildlife Service

\section{AKUTAN}

Several thermal springs and a small fumarole field are lcoated in Hot Springs Bay Valley, about $4 \mathrm{~km}$ northwest of Akutan Harbor and $10 \mathrm{~km}$ northeast of active Akutan Volcano. The chloride-rich springs have surface discharge temperatures ranging from $40^{\circ}-85^{\circ} \mathrm{C} ;$ geothermometers give reservoir temperature estimates of $180^{\circ}-190^{\circ} \mathrm{C}$. Geophysical investigations suggest that much of the valley is underlain by warm waters. The resource area lies close to a small but well-protected natural harbor that serves as the base of operations for several bottom-fishing and crabbing vessels, floating fish processors and a shore-based bottom-fish processing plant. Geothermal resources in the valley have the potential of supplying all the energy needs, through direct use and electrical power generation, for the processors and the nearby village of Akutan.

Agencies involved:

Alaska Division of Geological \& Geophysical surveys Geophysical Institute, U. of Alaska

Akutan village Council

Aleut Corporation

U. S. Fish and wildilfe service

ATKA

Two major fumarole flelds, Kliuchef and Milky River and associated low-Cl, $\mathrm{HCO}_{3}-\mathrm{SO}_{4}$ rich thermal springs are located on the west flank of the strato-volcano, Mt. Kiluchef. A third geothermal field, Korovin, lies in a valley about $6 \mathrm{~km}$ southwest of Korovin volcano. Gas geothermometry gives reservoir temperature estimates of $170^{\circ}-300^{\circ} \mathrm{C}$. The nearby native village of Atka has a subsistence based economy and is actively seeking an energy source to help develop a local commercial fishing industry. The proximity of the geothermal resources on northeast Atka to a good harbor and potential users make the area particularly attractive for further exploration. 


\title{
Agencles involved:
}

\author{
Alaska Division of Geological \& Geophysical Surveys \\ Atka Village Council \\ Aleut Corporation \\ U. S. Fish and Wildlife Service
}

\section{BARANOF}

Waters from eight thermal springs ranging from $40^{\circ}-50^{\circ} \mathrm{C}$ in temperature are used to heat local dwellings, a general store and a commercial bath house. The estimated reservoir temperature, based on geothermometry, is $95^{\circ} \mathrm{C}$. The springs flow from fractures in an Eocene trondfemite pluton. The site lies within the Tongass National Forest.

Agencies involved:

Alaska Division of Geological \& Geophysical surveys U. S. Forest Service, Tongass National Forest

\section{BELL ISLAND and BAILEY BAY}

At Bell Island, waters from numerous springs ranging in temperatures form $67^{\circ}-74^{\circ} \mathrm{C}$ are collected in cisterns and used to heat lodges, cabins, and the swimming pool of a fishing resort complex. The owner has expressed interest in cascaded direct-use of the thermal spring waters for greenhouses and aquaculture. Geothermometers give an estimated reservoir temperature of $135^{\circ} \mathrm{C}$. Nearby Bailey Bay Hot Springs have surface discharge temperatures as high as $91^{\circ} \mathrm{C}$ and an estimated reservoir temperature of $150^{\circ} \mathrm{C}$. The U. S. Forest Service has proposed placing the Bailey Bay site into an ecological preserve status.

Agencies involved:

Alaska Division of Geological \& Geophysical Surveys U. S. Forest Service, Tongass National Forest Bell Island Hot springs Fishing Resort

\section{CHENA and CIRCLE}

These sites are both examples of hydrothermal resources resulting from the percolation and circulation of meteoric waters along fractures and faults in Cretaceous intrusive bodies and overlying metamorphic units in central Alaska. Additionally both have similar histories of development and direct use, first serving local mining communities as bathing and small-scale agricultural facilities, and later 
becoming major recreational areas for residents of Falrbanks. At circle water from nine springs, with a maximum temperature of $60^{\circ} \mathrm{C}$ and combined flow of $17001 \mathrm{pm}$, is used to heat a large hotel, swimming pool, and small greenhouse. At Chena effluent from ten springs, with a combined flow of $8401 \mathrm{pm}$ and maximum temperature of $57^{\circ} \mathrm{C}$, is used to heat a lodge and enclosed swimming pool. Owners of both resorts would eventually like to drill wells to increase hot water production, but are presently working to expand the direct use of natural discharge. Based on geothermometry, estimated reservoir temperatures for both sites are $130^{\circ}-145^{\circ} \mathrm{C}$.

Agencies involved:

Alaska Division of Geological \& Geophysical Surveys Geophysical Insitiute, $U$. of Alaska U. S. Geological Survey, Alaska Branch Chena Hot Springs Resort Circle Hot springs Resort

GODDARD

Four springs ranging in temperature from $30^{\circ}-66^{\circ} \mathrm{C}$ are located $22 \mathrm{~km}$ south of sitka on the coast of Baranof Island. Geothermometry gives a reservoir temperature estimate of $140^{\circ} \mathrm{C}$. The site was developed as a health spa complete with hospital facilities during the $1920^{\prime} \mathrm{s}$. The spring waters are currently used for community bath houses. The city of sitka, which owns the springs, has considered further development of the area but the sitka community residents have expressed their desire to maintain the area as a recreational site.

Agencies Involved:

Alaska Division of Geological \& Geophysical Surveys sitka City and Borough Government

\section{KLAWASI - COPPER RIVER BASIN}

Two groups of mud volcanoes are located in the Copper River Basin: the Tolsana group west of Glennallen and the Klawasi group east of Glennallen. Although both groups discharge highly saline waters, the Klawasi group is distinguished by warmer waters $\left(20^{\circ} \mathrm{C}\right)$ accompanied by vast amounts of $\mathrm{CO}_{2}$. The saline waters emanating from both groups are thought to originate from over-pressured zones in cretaceous marine sediments that underlie the basin. The proximity of the Klawasi group to the extremely large Quaternary volcanoes of the western wrangel1 Mountains lead many to speculate that a significant geothermal resource might underlie the mud 
volcanoes. This view was supported when researchers from the Geophysical Institute, University of Alaska found gravity, magnetic, self-potential, and helium anamolies in the Klawasi area, the combination of which they suggested might indicate hydrothermal activity. However, recent

geochemical and isotopic investigations of the mud volcano fluids by ADGGS have shown that the reservoirs feeding the Klawasi mud volcanoes are probably of moderate temperature $\left(100^{\circ}\right.$ to $\left..125^{\circ} \mathrm{C}\right)$. Fluid geochemical and isotopic evidence also suggests that a body of magma has intruded deep-seated Iimestone-formations beneath the Rlawasi area and is responsible for the production of the large quantities of $\mathrm{CO}_{2}$ through thermogenic and geochemical processes. Land ownership in the region is divided among the local native corportaion, the State of Alaska, and the National Park service.

Agencles Involved:

Alaska Division of Geological \& Geophysical Surveys Geophysical Institute, $U$. of Alaska

U. S. Geological Survey, Alaska Branch

Wrangell - st. Elias National Park

AHTNA - Copper River Native Association

\section{MARUSHIN}

The Makushin geothermal area is associated with Makushin volcano, a major volcanic center in the Aleutian arc. The hydrothermal system consists of a bolling hot-water reservoir overlain by a discontinuous vapor-dominated zone that discharges steam and gases from several fumarole fields located on the south and east flanks of the volcano. Numerous low-Cl, $\mathrm{HCO}_{3}-\mathrm{SO}_{4}$ rich thermal springs emanate downslope from the fumaroles: several alkal1-Cl, $\mathrm{HCO}_{3}-\mathrm{SO}_{4}$ rich thermal springs occur at lower elevations. Gas geothermometry applied to a $150^{\circ} \mathrm{C}$ superheated fumarole gives a reservoir temperature estimate of $300^{\circ} \mathrm{C}$. Host reservoir rock is a highly-fractured gabbro-norite stock.

Reconnaissance investigations of the area's geothermal

resources were undertaken by the Alaska Division of

Geological and Geophysical Surveys in 1980 and 1981 under $a$

program funded by the U. S. Department of Energy and the State of Alaska. From 1982 - 1984 the Alaska Power

Authority administered a state funded $\$ 5$ million exploratory drilling program with Republic Geothermal, Inc. of California the prime contractor. Three $460 \mathrm{~m}$ deep thermal gradient holes were drilled in 1982. The hottest temperature encountered was $195^{\circ} \mathrm{C}$ at the bottom of the hole drilled at the head of Makushin Valley. In 1983 a $593 \mathrm{~m}$ test well (ST-I) drilled near the same site verified that a resource suitable for generating electrical power exists. Bottom hole temperature measurements were $195^{\circ} \mathrm{C}$ with 
geothermometers indicating deeper reservoir temperatures of $220^{\circ} \mathrm{C}$ and higher. Engineering tests Indicate that the single fracture encountered could supply two production welis each capable of ariving a 5 MW turbine. In 1984, electrical resistivity surveys and an additional thermal gradient hole drilled to 490 m near sugarloaf Cone delineated the north and east boundaries of the wedge shaped main reservoir which dips to the south and west of ST- 2 . The conclusion of all results indicate that the hydrothermal fluids which feed ST-1 are derived from a deep parent reservoir approximately centrally located beneath the volcano and any future production wells should be sited at or upvalley of ST-1. A geological engineering and hazards study of the site has been recently completed by ADGGS. The resource area lies $25 \mathrm{~km}$ west of the village of unalaska and Dutch Harbor, the largest natural deep-water harbor in the Aleutian Islands. The village and harbor serve as the major base of operations for the rich North Pacific and Bering Sea fisheries and for 011 and gas exploration on the Bering sea shelf. The 10 MW electrical power needs of the community and fish processing industry is currently supplied by diesel-fired generators.

Agencies Involved:

Alaska Division of Geological \& Geophysical Surveys Alaska Power Authority Geophysical Institute, $U$. of Alaska Repubilc Geothermal Inc., California Ounalashka Corporation Unalaska village council Aleut Corporation U. S. Fish and Wildilfe Service Alaska Department of FIsh and Game Alaska Division of O1I and Gas

\section{MANLEY}

Hot springs at Manley, centered on the 236-acre Dart homestead, are used to heat a house, large greenhouses, and a small commercial bath, as well as providing the primary water supply for the community of Manley. Discharge temperatures range from $18^{\circ}-61^{\circ} \mathrm{C}$, with reservoir estimates of $70^{\circ}-130^{\circ} \mathrm{C}$. The Bean Ridge Native Corporation has selected all available land surrounding the Dart property and are interested in geothermal exploration and development. Geophysical and geochemical studies have been carried out to help site a well on the Dart property. Capital limitations prevent immediate development of the resource, but a potential for greater direct use of spring waters exists. From 1906 to 1912 Manley was the site of the most extensive direct use of geothermal energy to date in Alaska. During the height of placer mining activity in the 
Tofty, Eureka, and Baker $\mathrm{Cr}$. areas, Manley served as a trade center which boasted a 60 room hotel, public baths, extensive poultry, hog and dairy barns, greenhouses and commercial truck gardens all heated with geothermal energy.

Agencies involved:

Geophysical Institute, U. of Alaska

Alaska Division of Geological \& Geophysical Surveys

Bean Ridge Native Corporation

Manley Hot Springs Resort

\section{MOUNTT SPURR}

Mount Spurr is a large andesitic stratovolcano located on the west side of upper cook Inlet. The volcano last erupted in 1953 scattering ash over Anchorage $130 \mathrm{~km}$ to the east. Surface manifestations of geothermal activity include a $1 \mathrm{~km}$ long zone of warm springs $\left(4^{\circ} \mathrm{C}\right)$. In the valley immediately south of Crater Peak, a fumarole field around crater Peak, and evidence of ice melting by hydrothermal activity at an elevation of $2900 \mathrm{~m}$. Preliminary results of geological and geochemical studies of Mount Spurr volcanic rocks by ADGGS and the University of Alaska provide abundant evidence for a shallow-level magma system which has been active during late Pleistocene and Holocene time. Geophysical and geochemical surveys were conducted in 1985 by the University of Alaska, Geophysical Institute in the area south of Mount spurr. These investigations located large electrical self-potential anomalies and extensive zones of low resistivity which are overlapped and surrounded by areas of anomalously high He and $\mathrm{Hg}$ values. The south side of Mt. Spurr has been the site of two state of Alaska geothermal lease sales. The lease holders are actively exploring, for geothermal resources which they plan to use for agricultural purposes. Anchorage presently obtains most of its electricity from turbines fired by natural gas from the upper cook Inlet oil fields. A part of Mt. Spurr lies within a National Park.

Agencies Involved:

Geophysical Institute, U. of Alaska

Alaska Division of Geological \& Geophysical Surveys

Alaska Division of $O 11$ and Gas

U. S. Geological Survey, Alaska Branch

\section{PIIGRIM}

Two hot springs $\left(81^{\circ} \mathrm{C}\right)$ and a large oval of thawed ground in an area of deep continuous permafrost are surface manifestations of geothermal resources in the Pilgrim River valley $75 \mathrm{~km}$ north of Nome, Alaska. The valley is believed 
to be a downdropped fault block of pre-Phanerozoic gneiss and intrusive Mesozoic granites which 18 overlain by a thick (200m) sequence of Tertiary (?) sedimentg. A shallow pancake-shaped hot water reservolr ( $1 \mathrm{~km}^{2}$ ) was postulated from reconnalssance geologic, geophysical, hydrologic and geochemical studies conducted by the Geophysical Institute, Unlversity of Alaska and ADGGS. The reservolr was later substantiated by $\mathbf{s i x}$ geothermal gradient wells drilled under contract to the Alaska Division of Energy and Power

Development during 1979 and 1982 . The reservolr, $14 \mathrm{~m}$ below the surface, $1820 \mathrm{~m}$ thick and $91^{\circ} \mathrm{C}$. No deep conduit was discovered and the source for the heat is still in question. cation and silica geothermometers predict reservoir temperatures of $110^{\circ}-148^{\circ} \mathrm{C}$. There $1 \mathrm{~s}$ probably $19 \mathrm{MW}$ available for local direct-use development. A road now connects Nome to the springs which are used currently for recreation. Future development is uncertain. The springs and surrounding land are owned by the Catholic Church.

Agencies involved:

Geophysical Institute, U. of Alaska Alaska Division of Geological \& Geophysical surveys Alaska Department of Commerce and Economlc Development Woodward-clyde Consultants

\section{SUMMER BAY}

Two thermal springs located near the village of Unalaska about two $\mathrm{km}$ up-valley from Summer Bay on Unalaska Island, feebly emit chloride-rich $30^{\circ} \mathrm{C}$ waters. In 1980 two shallow test wells spaced $200 \mathrm{~m}$ apart were drilled into iron-stained sediments located on the shore of a lake about $1 / 2 \mathrm{~km}$ downvalley from the springs. Both wells encountered a warm water aquifer at about $13 \mathrm{~m}$ and bedrock at $17 \mathrm{~m}$. Artesian flow from well 1 was 180 lpm at $50^{\circ} \mathrm{C}$; well 2 flow was 30 Ipm and $44^{\circ} \mathrm{C}$... The wells have been plugged and the geothermal resource remains un-utilized.

Agencies involved:

Alaska Division of Geological \& Geophysical Surveys Alaska Department of Commerce and Economic Development Ounalashka Corporation Unalaska Village Council

TENAKEE

Elghteen springs ranging from $30^{\circ}-40^{\circ} \mathrm{C}$ in temperature $11 \mathrm{e}$ along the shoreline at Tenakee Village. The springs appear to originate as meteorlc waters that circulate along deep fractures associated with nearby fault zones. 
Geothermometry gives reservoir temperature estimates of $65^{\circ}$ - $100^{\circ} \mathrm{C}$. Waters from one of the springs is used for a community bath house. Under a $U$. $s$. Department of Energy Program, the Alaska Department of Commerce and Economic Development contracted for exploratory drilling to determine whether hot waters suitable for direct-use were present at shallow depths. Six test wells were drilled; the deepest reached $30 \mathrm{~m}$ ( $100 \mathrm{ft}$.$) and produced 30^{\circ} \mathrm{C}$ waters at a rate of about $81 \mathrm{pm}$. Water temperatures and flow rates from the wells were deemed insufficlent for district heating.

Agencies involved:

Alaska Division of Geological \& Geophysical Surveys Alaska Department of Commerce and Economic Development village of Tenakee

\section{UMNAK}

Numerous hot springs, fumaroles, and several small geysers with temperatures to $102^{\circ} \mathrm{C}$ are located in Geyser Blght valley, and constitute probably the best known, most widespread, and hottest thermal spring system in Alaska. silica and cation geothermometers give reservoir temperature estimates of $180^{\circ}-200^{\circ} \mathrm{C}$; sulfate-water oxygen isotope geothermometry suggests deep reservoir temperatures are as high as $265^{\circ} \mathrm{C}$. The resource area 1 les between huge okmok Caldera to the northwest and Mount Recheschnol and Vsevidof, two large stratovolcanoes, to the southwest. Chloride thermal springs also occur in neighboring Hot springs Cove and Partov Cove valleys. Lands in the Geyser Bight and surronding areas have been selected by the state of Alaska, Nikolski Village Corporation, st. George Village Association and the Aleut corporation. The nearest community is the native village of Nikolski, $40 \mathrm{~km}$ southwest of Geyser Bight. Because of the remoteness of the three sites, the lack of protected deep-water harbors, and low population base, geothermal resource development appears unlikely in the near future.

\section{Agencies involved:}

Alaska Division of Geological \& Geophysical surveys U. S. Geological Survey

U. S. Fish and Wildilfe service

Aleut corporation

Nikolski village Council

st. George Village Association 
Four nonproducing exploratory oll wells drilled into the thick Tertiary sedimentary sequence overlying granitic basement rocks in this area had geothermal gradients of $41^{\circ}$ to $123^{\circ} \mathrm{C} / \mathrm{km}$. Limited geophysical and geochemical data from the area have been Interpreted by Turner and Wescott (1982) as possibly indiçating a shallow low-grade geothermal reservoir $100 \mathrm{~km}^{2}$ in area, that could be tapped for direct use. There is no surface manifestation of the resource, no fluids were encountered in the wells, and the source of the heat remains highly speculative. Traditionally an area of small-scale agricultural activity, it has recently seen extensive suburban development. Other potential users include the State Division of Parks, Nancy Lake Recreation Area.

Agencies involved:

Geophysical Insitute, University of Alaska 
APPENDIX B -AGENCIES INVOLVED IN ALASKA GEOTHERMAL RESOURCES

EXPLORATION AND ASSESSMENT

Federal

U. S. Department of Energy, Idaho Operations office, 785 DOE Place, Idaho Falls, ID 83402.

U. S. Geological Survey, Branch of Igneous and Geothermal Processess, MS-910, 345 Middlefield Rd., Menlo Park, CA 94025 .

U. S. Geological Survey, Water Resources Division, MS-34, 345 Middlefield Rd., Menlo Park, CA 94025.

U. S. Geological Survey, Alaska Branch, Gould Hall, Alaska Pacific University, Anchorage, AK 99501.

U. S. Department of the Navy, Naval Weapons Center, Energy Program Management office, China Lake, CA 93555-6001.

State

Alaska Department of Natural Resources, Division of Geological and Geophysical Surveys, 794 University Ave., Falrbanks, AK 99709; Pouch 7-028, Anchorage, AK 99510; PO Box 772116, Eagle River, AK 99577; Pouch $M$, Juneau, AK 99811 .

Alaska Power Authority, 701 E Tudor Road, PO BoX 190869, Anchorage, AK 99519-0869.

University of Alaska Geophysical Institute Geology Department

Petroleum Engineering Department

Fairbanks, AR 99755.

Alaska Department of Fish \& Game, Division of Fisheries Rehabilitation, Enhancement \& Development, 333 Raspberry, Anchorage, AK 99518; PO Box 3-2000, Juneau, AR 99802. 


\section{Private}

Dames \& Moore, 800 Cordova, Suite 101, Anchorage, AK 99501.

Geothermal Resources International Exploration Co., 1825 S. Grant st., Suite 900 , San Mateo, CA, 94402 .

Premier Geophysics Inc. 1184 Forge Walk, Vancouver, BC, Canada V6H-3P9.

Republic Geothermal, 11823 E. Slauson Ave, Sante Fe Springs, CA, 90670 .

William Ogle, 3801 w 44 th Ave, Anchorage, AR 99502.

Woodward-Clyde, One Walnut Creek Center, 100 Pringle Ave, Walnut Creek, CA 94596 (Ben E. Lofgren).

\section{ECONOMIC DEVELOPMENT}

Ahtna' T'aene Nene', Copper River Native Association, Drawer G, Copper center, AK 99573.

Akutan Village Council, Akutan, AK 99553.

Alaska Department of Commerce and Economic Development, Sulte 722 Frontier Bullding, 3601 ' $C$ ' street, Anchorage, AK 99503; PO Box D, Juneau, AK 99811.

Alaska Power Authority, 701 E. Tudor Road, PO Box 190869, Anchorage, AK 99519-0869.

Aleut Corporation, 2550 Denali, Suite 900, Anchorage, AK 99503.

Atka Village Council, Atka, AK 99502.

Bean Ridge Native Corporation, Manley Hot Springs, AK 99756. Dennis P. Carro11, Box 80562, Fairbanks, AK 99708.

Chaluka Corporation, Nikolski, AK 99638.

Roger \& Barbara Cotting, Chena Hot Springs Corp., 1919

Lathrop st., Drawer 25, Fairbanks, AK 99707.

Chuck Dart, Manley Hot Springs, AR 99756.

Jim Dawson \& Bud Seltenrelck, 2165 Dawson Road, North Pole, AK 99705.

Suzan Dilley, SR 2690, Wasilla, AK 99687. 
False Pass Native Corporation, False Pass, AR 99583.

Dolly Faulkner, PO Box 246, Bethel, AK 99559.

Geothermal Resources International Exploration Co., $1825 \mathrm{~S}$. Grant st., suite 900, San Mateo, CA 94402.

Doris Loennig Attorney, 5157 th Ave., Falrbanks, AK 99701. Robert Miller, PO Box 729, Fairbanks, AR 99707.

ounalashka corporation, P.O Box 149, Unalaska, AK 99685.

Don Peterson, Box 8762, Ketchikan, AK 99901.

c. J. Phillips, Nome, AK 99762 .

Richard Rome \& Donna Waldtlow, $12404 \mathrm{NE} 29 \mathrm{th}$ St., Belleview, WA 98005 .

Seth-de-ya-ah Native Corporation, Po Box 849, Fairbanks, AK 99707.

City of sitka, Box 79, 304 Lake st., sitka, AK 99835.

st. George Village Association, st. George Island, AK 99660.

Tanadquisix village corporation, st. Paul Island, AR 99660.

City of Tenakee Springs, PO Box 52, Tenakee Springs, AK 99841 .

Unalaska Village Council, Unalaska, AK 99685.

LEASING, PERMITTING AND REGULATORY

\section{Federal}

U. S. Bureau of Land Management, Fairbanks Support Center, 1541 Gafney, Fairbanks, AR 99703-1399.

U. S. Fish and wildlife service, 1011 E. Tudor Rd.' Anchorage, AR 99503; Aleutian National Wildilfe Refuge, Box 5251, Seattle, WA 98791.

0. S. Forest Service, 709 W. 9th St. Juneau, AK 99801; Tongass Forest Manager, 9 1/2 Mile Glacier Hwy, Juneau, AK 99801.

U. S. Environmental Protection Agency, Region X, 1200 sixth st. Seattle, WA 98101 . 
state

Alaska Department of Natural Resources, Division of oil and Gas, 3601 'C' St., PO Box 7034, Anchorage, AK 995100734.

Alaska Department of Natural Resources, Division of Iand and Water Management, 3601 'C' St., PO Box 7005, Anchorage, AK 99510-0734.

Alaska Department of Fish and Game, 333 Raspberry Rd., Anchorage, AK 99502; PO BOX 3-2000, Juneau, AK 99802.

Alaska Department of Environmental Conservation, 437 ' $E$ ' street, suite 200, Anchorage, AK 99501.

\section{MISCELIANEOUS}

U. S. National Oceanic and Atmospheric Administration, 600 spruce St., Boulder, Co 80302 .

University of Utah Research Institute, 391 Chipeta Way, suite C, Salt Lake City, UT 84108.

U. S. National Park Service, Alaska Regional Office, $540 \mathrm{~W}$. Fifth Ave., Anchorage, AK 99501. 